\title{
Geobiology of the stratified \\ central Baltic Sea water column
}

\author{
Dissertation \\ zur Erlangung des mathematisch-naturwissenschaftlichen Doktorgrades \\ „Doctor rerum naturalium“ \\ der Georg-August-Universität Göttingen \\ im Promotionsprogramm Geowissenschaften \\ der Georg-August University School of Science (GAUSS)
}

vorgelegt von

Christine Berndmeyer

aus Cloppenburg

Göttingen, 2014 


\section{Betreuungsausschuss}

Prof. Dr. Volker Thiel, GZG, Abteilung Geobiologie

Dr. Martin Blumenberg, Bundesanstalt für Geowissenschaften und Rohstoffe

\section{Mitglieder der Prüfungskomission}

Referent: $\quad$ Prof. Dr. Volker Thiel, GZG, Abteilung Geobiologie

Korreferent: Dr. Martin Blumenberg, Bundesanstalt für Geowissenschaften und Rohstoffe

weitere Mitglieder der Prüfungskomission:

Prof. Dr. Joachim Reitner, GZG, Abteilung Geobiologie

Prof. Dr. Daniel Jackson, Courant Research Center Geobiology

Dr. Steffen Kiel, GZG, Abteilung Geobiologie

Dr. Oliver Schmale, Leibnizinstitut für Ostseeforschung Warnemünde

Tag der mündlichen Prüfung:

20. August 2014 


\section{Acknowledgments}

Working in this project was a great experience and although Göttingen is not necessarily famous for its maritime flair, my work here allowed me keeping my marine background.

First of all, I cordially thank Martin Blumenberg for the opportunity to work in this Baltic Sea project, for his patient and diligent mentoring and his support during all stages of this thesis. I furthermore thank Volker Thiel for his scientific support, good advice, the hours spent for proofreading, and critical questions.

I thank Joachim Reitner, Daniel Jackson, Steffen Kiel, and Oliver Schmale for being members of my thesis committee.

In addition, I thank Oliver Schmale for help with sampling and onboard ship, and for constructive discussions. I am very thankful to my co-doctoral candidate Gunnar Jakobs for the nice times spent onboard ships, the scientific discussions and exchange of ideas, the nonscientific discussions and the mutual support.

Thomas Bode and Nadine Schäfer have always been helpful with any PC problems.

For help in laboratory and analytical support, I thank Cornelia Conradt, Lukas Kammel, Birgit Röhring, Andreas Reimer, Tobias Licha, Karsten Nödler and Jens Dyckmans.

Thanks to my colleagues Jan Bauermeister, Juliane Germer, Ines Herlitze, Jennifer Hohagen, Tim Leefmann, Eva-Maria Sadowski, and Leyla Seyfullah for lunch breaks, chats on the roof, and help with this work. Special thanks to Jan-Peter Duda for all his support during years of study in Bremen and the current support for our "double-finish".

I am very grateful to my family for never ending support, help, encouragement, and interest in what I am doing.

I am especially indebted to Timo Köhnsen who always supported my work but steadily reminds me what is really important.

This thesis was written as a part of the DFG research project "Aerobic and anaerobic methane consumption in the central Baltic Sea water column".

This thesis is dedicated to Anette and Klaus Berndmeyer. 


\section{Preface}

The following papers and manuscripts are part of this doctoral thesis:

Berndmeyer, C., Thiel, V., Blumenberg, M., 2014. Test of microwave, ultrasound and Bligh \& Dyer extraction for quantitative extraction of bacteriohopanepolyols (BHPs) from marine sediments. Organic Geochemistry 68, 90-94.

Berndmeyer, C., Thiel, V., Schmale, O., Blumenberg, M., 2013. Biomarkers for aerobic methanotrophy in the water column of the stratified Gotland Deep (Baltic Sea). Organic Geochemistry 55, 103-111.

Berndmeyer, C., Thiel, V., Schmale, O., Wasmund, N., Blumenberg, M., 2014b. Biomarkers in the stratified water column of the Landsort Deep (Baltic Sea). Biogeosciences Discussions 11, 9853-9887. Under review.

Blumenberg, M., Berndmeyer, C., Moros, M., Muschalla, M., Schmale, O., Thiel, V., 2013. Bacteriohopanepolyols record stratification, nitrogen fixation and other biogeochemical perturbations in Holocene sediments of the central Baltic Sea. Biogeosciences 10, 27252735.

Schmale, O., Blumenberg, M., Kießlich, K., Jakobs, G., Berndmeyer, C., Labrenz, M., Thiel, V., Rehder, G., 2012. Microbial methane oxidation at the redoxcline of the Gotland Deep (Baltic Sea). Biogeosciences 9, 4969-4977. 


\section{Contents}

$\begin{array}{ll}\text { Abstract } & 1\end{array}$

Chapter 1 - Introduction $\quad 3$

1.1 Molecular biomarkers $\quad 4$

$\begin{array}{ll}1.2 \text { Stratified water columns } & 7\end{array}$

$\begin{array}{ll}1.3 \text { Geobiology of stratified water columns } & 10\end{array}$

1.4 Holocene development of the Baltic Sea and the present situation 11

$\begin{array}{ll}1.5 \text { Sampling and analytical methods } & 16\end{array}$

1.6 Introduction to the following chapters 18

$\begin{array}{ll}\text { References } & 19\end{array}$

Chapter 2 - "Test of microwave, ultrasound and Bligh \& Dyer extraction for quantitative extraction of bacteriohopanepolyols (BHPs) from marine $\begin{array}{ll}\text { sediments" } & 27\end{array}$

2.1 Abstract 27

2.2 Introduction $\quad 27$

2.3 Methods 28

$\begin{array}{ll}2.4 \text { Results } & 30\end{array}$

2.5 Discussion 31

2.6 Conclusions 34

Acknowledgments 34

$\begin{array}{ll}\text { References } & 35\end{array}$

Chapter 3 - "Biomarkers in the stratified water column of the Landsort Deep

(Baltic Sea)" 41

3.1 Abstract $\quad 41$

3.2 Introduction $\quad 42$

3.3 Material and methods 43

3.4 Results 46

3.5 Discussion 53

3.6 Conclusions $\quad 59$

$\begin{array}{ll}\text { Acknowledgments } & 60\end{array}$

$\begin{array}{ll}\text { References } & 61\end{array}$ 
Chapter 4 - "Aerobic methanotrophy within the pelagic redox-zone of the Gotland Deep"

4.1 Abstract

4.2 Introduction

4.3 Methods

4.4 Results and discussion

4.5 Conclusions

Acknowledgments 86

References

Chapter 5 - "Biomarkers for aerobic methanotrophy in the water column of the stratified Gotland Deep (Baltic Sea)"

5.1 Abstract

5.2 Introduction

5.3 Methods

5.4 Results

5.5 Discussion 105

5.6 Conclusions and outlook

Acknowledgments

References

Chapter 6 - "Bacteriohopanepolyols record stratification, nitrogen fixation and other biogeochemical perturbations in Holocene sediments of the central Baltic Sea"

5.1 Abstract

5.2 Introduction

5.3 Study site and core stratigraphy

5.4 Materials and methods

5.5 Results

5.6 Discussion

5.7 Conclusions

Acknowledgments

References 



\begin{abstract}
The central Baltic Sea water column is permanently density stratified leading to stagnating bottom waters and a zonation into an oxic, suboxic and anoxic zone. The anoxic zone of the central Baltic Sea is characterized by strong methane gradients that indicate methane consumption in the suboxic zone. This thesis comprises five papers that are based on investigations of water column and sediment samples from the central Baltic Sea. The aim of these investigations was to assess the geobiology of this stratified system using biomarkers with a focus on bacteriohopanepolyols (BHPs). First, three different extraction methods were compared with respect to BHP yields. Microwave, ultrasound, and Bligh \& Dyer extraction revealed similar results for total extracted BHPs and studies were continued using microwave extraction. In the Landsort Deep, biomarkers were used to assess the geobiology in the whole water column. They mirrored the water column stratification and revealed different microbial communities. An initial multidisciplinary study including biomarker analysis revealed the presence of type I aerobic methanotrophic bacteria in the suboxic zone of the Gotland Deep. A following detailed investigation of Gotland Deep biomarkers in the oxic and suboxic zone and the underlying sediment showed high BHP concentrations in the suboxic zone and suggested that this zone is an important source layer for these compounds. The BHP signal found in the suboxic zone is also mirrored in the surface sediments. Subsequently, the Holocene geological record of BHPs was analyzed in a Gotland Deep sediment core covering all stages of the Baltic Sea development. BHPs reflected the onset of the stratification during Littorina stage and are of particular abundance during periods of pronounced anoxia. The studies presented in this thesis demonstrate biomarkers to be a versatile tool to assess microbial communities in present and past stratified environments and contribute to the general knowledge on the geobiology of stratified water columns.
\end{abstract}




\section{Introduction}

Geobiology is the science of the interactions between the non-living geosphere and the living biosphere. Much like the geosphere has an influence on the development and distribution of life, life, inversely, is able to change and shape the geosphere. Numerous topics such as early life environments, the photosynthetic oxygenation of the atmosphere, microbial mineral precipitation, or nutrient cycles are of geobiological interest. This thesis, however, is focused on the geobiology of the central Baltic Sea stratified water column, i.e. the distribution of microbial life in physicochemically differing water layers. A permanent pycnocline divides the present central Baltic Sea water column into an oxic, suboxic and anoxic zone. The resulting chemocline supports numerous microbial metabolisms, including the aerobic oxidation of methane.

This thesis was written in the context of the multidisciplinary project "Aerobic and anaerobic methane consumption in the central Baltic Sea water column" conducted by the geobiology group of the Georg-August-University of Göttingen and the working group "trace gases" of the Leibniz Institute for Baltic Sea Research Warnemünde (IOW). Methane is known to be a highly effective greenhouse gas that is amongst others produced in marine sediments. Microbial methane oxidation in the sediments and in the water column removes large amounts of the produced methane before it can reach the atmosphere and affects climate. Little was known about the microbial key players in methane oxidation, the amounts of methane consumed, and spatial and temporal variations of this process. Key questions within the project were:

- Is there aerobic and anaerobic oxidation of methane?

- Which microorganisms are involved in the consumption of methane?

- Are there spatial differences in the communities of these microorganisms and the amounts of methane consumed?

- Do seasonal variations have an influence on the communities and if so, how do they adapt? 
The first steps in answering these questions were done using a number of different methods, one of them being the analysis of molecular biomarkers. Some of these biomarkers, e.g. bacteriohopanepolyols, can be highly specific for certain microorganisms and related biogeochemical processes. Presence and distribution of biomarkers in the water, thus, are the main focus of this thesis. With respect to the biomarkers and with emphasis on bacteriohopanepolyols, further questions arose:

- Do the biomarkers in the water column reflect in situ production or are their distributions a result of transport?

- Apart from methanotrophy, what information do biomarkers yield on the occurrence of other biogeochemical processes?

- Are biomarker signals from the water column preserved in the sediment and can they be used to reconstruct the development of the Baltic Sea stratification?

Aim of this thesis was to apply water column biomarker data to identify microbial communities, methanotrophic microorganisms, their distribution in the water column, and the preservation of their signals in the sediments. The results of the studies discussed in the following chapters give insight into the highly dynamic and complex system of the present and past stratified water columns of the central Baltic Sea.

\subsection{Molecular biomarkers}

Biomarkers are biosynthetic organic compounds such as lipids (Brocks and Pearson, 2005). They can be preserved in sediments and sedimentary rocks and some are specific for certain groups of organisms (Brocks and Pearson, 2005; Brocks and Grice, 2011). Lipids are derived from lipid membranes that are used by all living cells as a boundary between the living intracellular and the non-living extracellular environment (Fig. 1a). These membranes are a semipermeable heterogeneous assembly of primarily lipids and proteins and their main function is to control the passage of water and solutes in or out of a cell (Fig. 1b; Kannenberg and Poralla, 1999). Constituents and internal structure vary between the domains of life. The basic construction, however, is an approximately $8 \mathrm{~nm}$ thick bilayer of amphipathic 


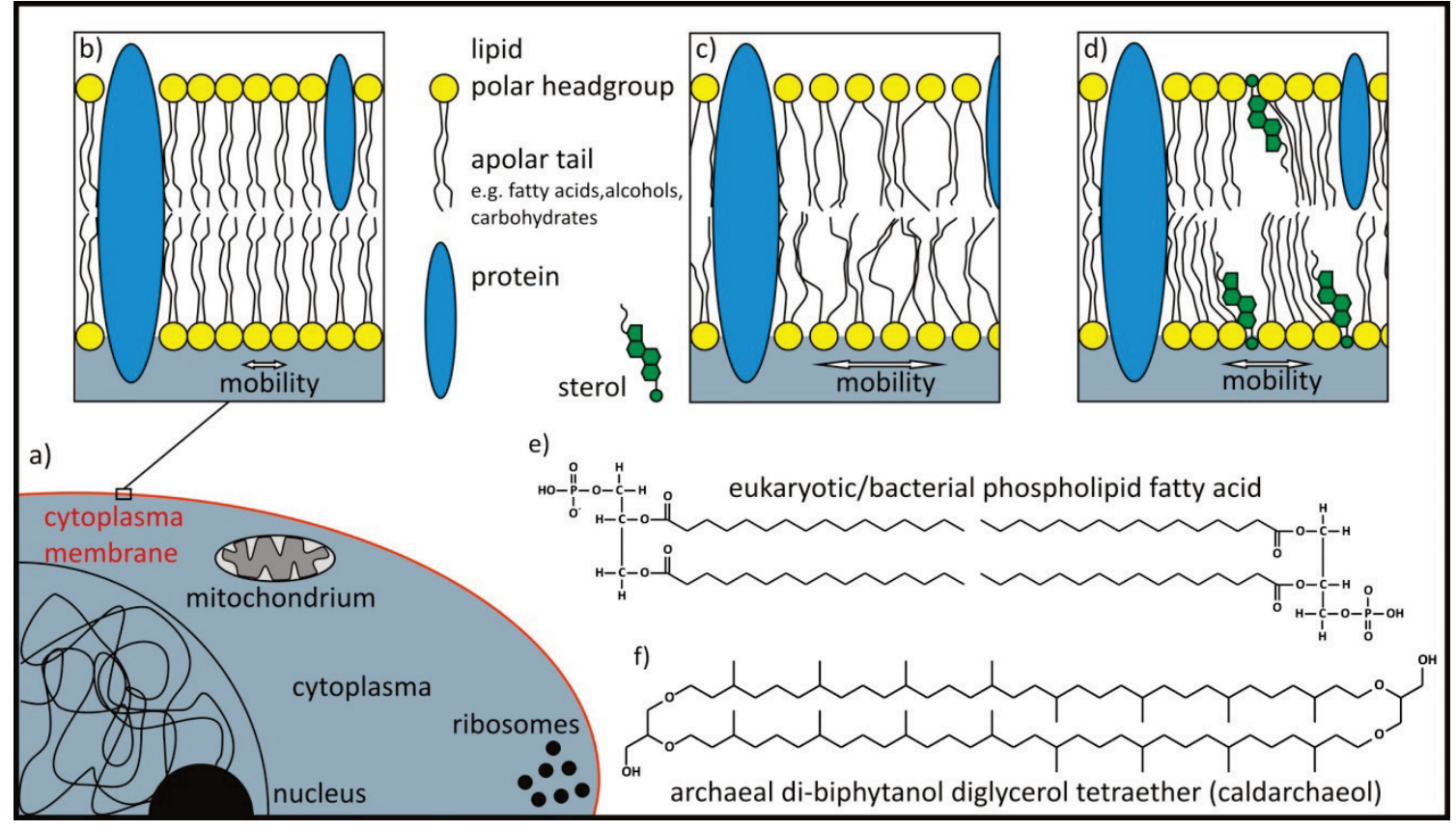

Fig. 1: Schematic overview of a eukaryotic cell and the cytoplasmic membrane construction. a) Section through a eikaryotic cell. The cytoplasma membrane is marked red. b) Section of a cytoplasma membrane consisting of lipids and proteins. Saturated apolar "tails" confine molecule mobility and membrane fluidity. c) Unsaturated apolar "tails" avoid dense packaging of the molecules and increase molecule mobility and thus, membrane fluidity. d) A sterol positioned between the lipids restricts mobility but avoids dense packaging of the lipid molecules. e) Two phospholipid fatty acids arranged in a bilayer. f) Archaeal isoprenoid hydrocarbons forming a monolayer.

compounds, with their polar hydrophilic heads oriented to the aqueous inside and outside of the cell and the non-polar ends forming a hydrophobic zone in between (e.g. Campbell and Reece, 2003; Konhauser, 2007). The main constituents of bacterial and eukaryotic membranes are phospholipids. These lipids consist of fatty acids (usually $\mathrm{C}_{12}-\mathrm{C}_{24}$ ) attached to a glycerol and a phosphate group (Fig. 1e). Archaeal membranes differ in diether-bound and shorter $\left(\mathrm{C}_{15}\right.$ to $\left.\mathrm{C}_{25}\right)$ isoprenoid hydrocarbons that are attached to one head group or longer tetraether-bound $\left(\mathrm{C}_{40}\right)$ isoprenoid hydrocarbons that connect the inner and outer polar heads to form a monolayer (Fig. 1f; Peters et al., 2004).

Within a narrow temperature range, a lipid membrane is fluid because the membrane molecules are mobile. Higher temperatures disorder the membrane molecules, whilst lower temperatures make them densely packed (Campbell and Reece, 2003; Peters et al., 2004). Fluidity is necessary for the biological function of membranes and the relevant temperature range can be enhanced and adapted by modification of the lipid composition (Kannenberg and Poralla, 1999). In both 
bacterial and eukaryotic membranes, fluidity is enhanced by the incorporation of unsaturated fatty acids into the phospholipids (Fig. 1c). Other compounds influencing fluidity are hopanoids and sterols that are positioned between the phospholipids (Fig 1d). They are able to reduce movement of the phospholipids when the temperature is rising but also avoid dense packaging at low temperatures (Campbell and Reece, 2003; Peters et al., 2004). Archaea adapt their membranes to temperatures by either building monolayer membranes from tetraether-bound isoprenoids that reduce movement of the membrane molecules and preserve fluidity in high temperature environments, or by the incorporation of several cyclopentyl rings (Peters et al., 2004). There are numerous molecules that change membrane properties. These membrane constituents do not only differ between the domains of life. Some are even characteristic, for certain genera (Brocks and Pearson, 2005; Brocks and Grice, 2011). Thus, membrane constituents are biological markers for the presence of these organisms. The analysis of membrane constituents or their residues is a useful tool to gain information about microbial communities in recent environments but can also be used to reconstruct paleo-communities.

If analyzed for stable carbon isotope composition, biomarkers can yield further information about their producers and the substrates used for membrane construction. During the uptake of carbon in form of $\mathrm{CO}_{2}\left(\right.$ and $\left.\mathrm{HCO}_{3}{ }^{-}\right), \mathrm{CH}_{4}$, or organic material, the lighter ${ }^{12} \mathrm{C}$ is fractionated over the heavier ${ }^{13} \mathrm{C}$. In the case of methanotrophy, the substrate $\mathrm{CH}_{4}$ is often already strongly depleted in ${ }^{13} \mathrm{C}$, especially if of biogenic origin. Methanotrophs further fractionate during uptake and incorporation into their membranes. Therefore, lipids of methanotrophs are usually characterized by very low $\delta^{13} \mathrm{C}$ values, compared to other organic materials (Pancost and Pagani, 2006).

\subsubsection{Bacteriohopanepolyols (BHPs)}

Bacteriohopanepolyols are biomarkers that are so far only known to be produced by bacteria (Ourisson and Albrecht, 1992). BHPs consist of the basic pentacyclic $\mathrm{C}_{30}$ hopane linked to a $C_{5} n$-alkyl polyhydroxylated unit (Fig. 2; Rohmer et al., 1984; Neunlist and Rohmer, 1985). This side chain is highly variable, with attached polar moieties at its end, different numbers of hydroxy groups, or the $\mathrm{C}_{35}$ hydroxy group can be exchanged with an amino group (Neunlist and Rohmer, 1985). The function 
of BHPs remains unresolved so far. A first assumption was that BHPs in bacterial membranes might fulfill the same membrane stabilizing function as the structurally similar sterols in eukaryotes (Ourisson and Albrecht, 1992; Kannenberg and Poralla, 1999). The squalene-hopene-cyclase necessary for BHP production, however, was only identified in $\sim 10 \%$ of bacteria with sequenced genomes and hence, BHPs might not be as important as assumed for bacterial membranes (Pearson et al., 2007). An alternative relation of BHP production to $\mathrm{N}$-fixation is also under debate (e.g. Berry et al., 1991; Pearson et al., 2007; Blumenberg et al., 2009; Blumenberg et al., 2012). Despite the uncertainty of their function, some BHPs are produced by distinct bacterial genera and are nevertheless useful

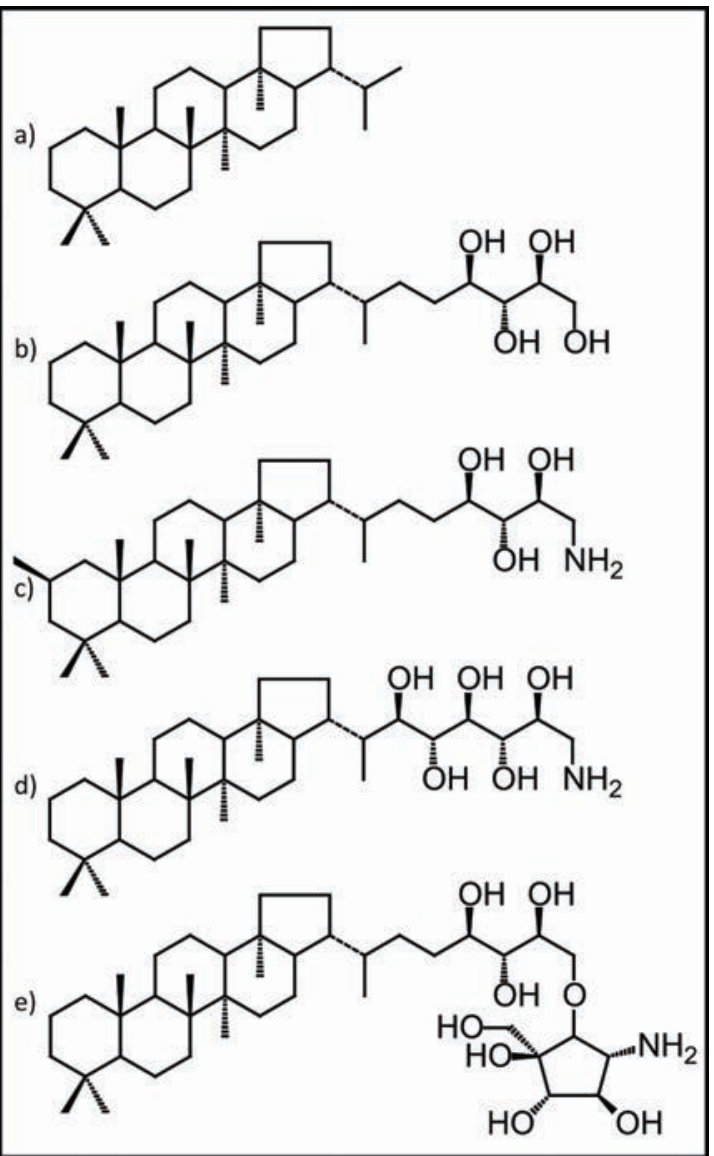

Fig. 2: The basic hopane and a selection of the variable BHPs.

a) hopane

b) bacteriohopane-32,33,34,35-tetrol (BHT)

c) 2-methyl-35-aminobacteriohopane-32,33,34-triol

d) 35-aminobacteriohopane-30,31,32,33,34-pentol

e) bacteriohopanetetrol cyclitol ether tools for their identification in present and past environments.

\subsection{Stratified water columns}

Stratified water columns are the result of natural salinity and temperature variations leading to density variations in different water layers. Put simply, every water column is at least seasonally stratified, usually by a warmer mixed surface layer and an underlying colder deep water layer, divided by a pycnocline (zone of strong density gradient; Colling et al., 2001). The modern world ocean's conveyorbelt circulation, for example, is based on a strong stratification with very cold and oxygen rich water masses sinking down and ventilating the deep sea (Colling et al., 2001; Meyer and Kump, 2008). 


\begin{tabular}{ccc}
\hline $\begin{array}{c}\mathrm{O}_{2} \\
{\left[\mathrm{ml} \mathrm{I}^{-1}\right]}\end{array}$ & $\begin{array}{c}\mathrm{O}_{2} \\
\text { regime }\end{array}$ & $\begin{array}{c}\text { Physiological } \\
\text { regime }\end{array}$ \\
\hline $8.0-2.0$ & oxic & (norm)oxic \\
$2.0-0.2$ & dysocix & hypoxic \\
$2.0-1.0$ & moderate & \\
$1.0-0.5$ & severe & \\
$0.5-0.2$ & extreme & \\
$0.2-0.0$ & suboxic & \\
$0.0\left(\mathrm{H}_{2} \mathrm{~S}\right)$ & anoxic (euxinic) & anoxic \\
\hline
\end{tabular}

Tab. 1: Terminology of low oxygen regimes (altered after Tyson and Pearson, 1991)
Some persistently stratified water columns, however, such as the fully marine Cariaco Basin, the semienclosed Black Sea, the Framvaren and Mariager Fjords, and the Baltic Sea, are characterized by hypoxic to anoxic/euxinic conditions (Fig. 3a; see Tab. 1 for terminology; Konovalov et al., 2005; Strauss, 2006; Meyer and Kump, 2008). These settings share characteristics such as strong density stratification, high primary production and a silled basin topography. The density stratification of the water column decouples the deep water from the atmosphere and excludes this water mass from gas exchange, i.e. oxygen supply. A sill or basin geomorphology of the sea floor can additionally restrict water exchange by deep currents (Meyer and Kump, 2008). High primary production in the surface waters induces the export of large amounts of organic material to the isolated deeper water layers. The decomposition of this material rapidly consumes any oxygen $\left(\mathrm{O}_{2}\right)$ present in these layers. Nutrients are released and trapped below the pycnocline. These nutrients only become available occasionally for the surface waters by turbulent mixing and internal waves at the pycnocline (Fig. 3b; Meyer and Kump, 2008; Reissmann et al., 2009). The decomposition of organic material, however, proceeds in the absence of $\mathrm{O}_{2}$, as certain prokaryotes are capable of $\mathrm{O}_{2}$-independent metabolism pathways, e.g. nitrate $\left(\mathrm{NO}_{3}{ }^{-}\right)$or sulfate $\left(\mathrm{SO}_{4}{ }^{2-}\right)$ reduction (Konovalov et al., 2005). A metabolic side product of sulfate reduction is the toxic hydrogen sulfide $\left(\mathrm{H}_{2} \mathrm{~S}\right)$, that accumulates in the anoxic water column (euxinic conditions; Tyson and Pearson, 1991; Konovalov et al., 2005). As a result of topography and primary production, hypoxia or anoxia/euxinia establishes in the deep water layers. The water column is finally divided into an upper oxic zone and an underlying anoxic zone, with a chemocline (zone of strong gradients in various oxidants and reductants) in between. 

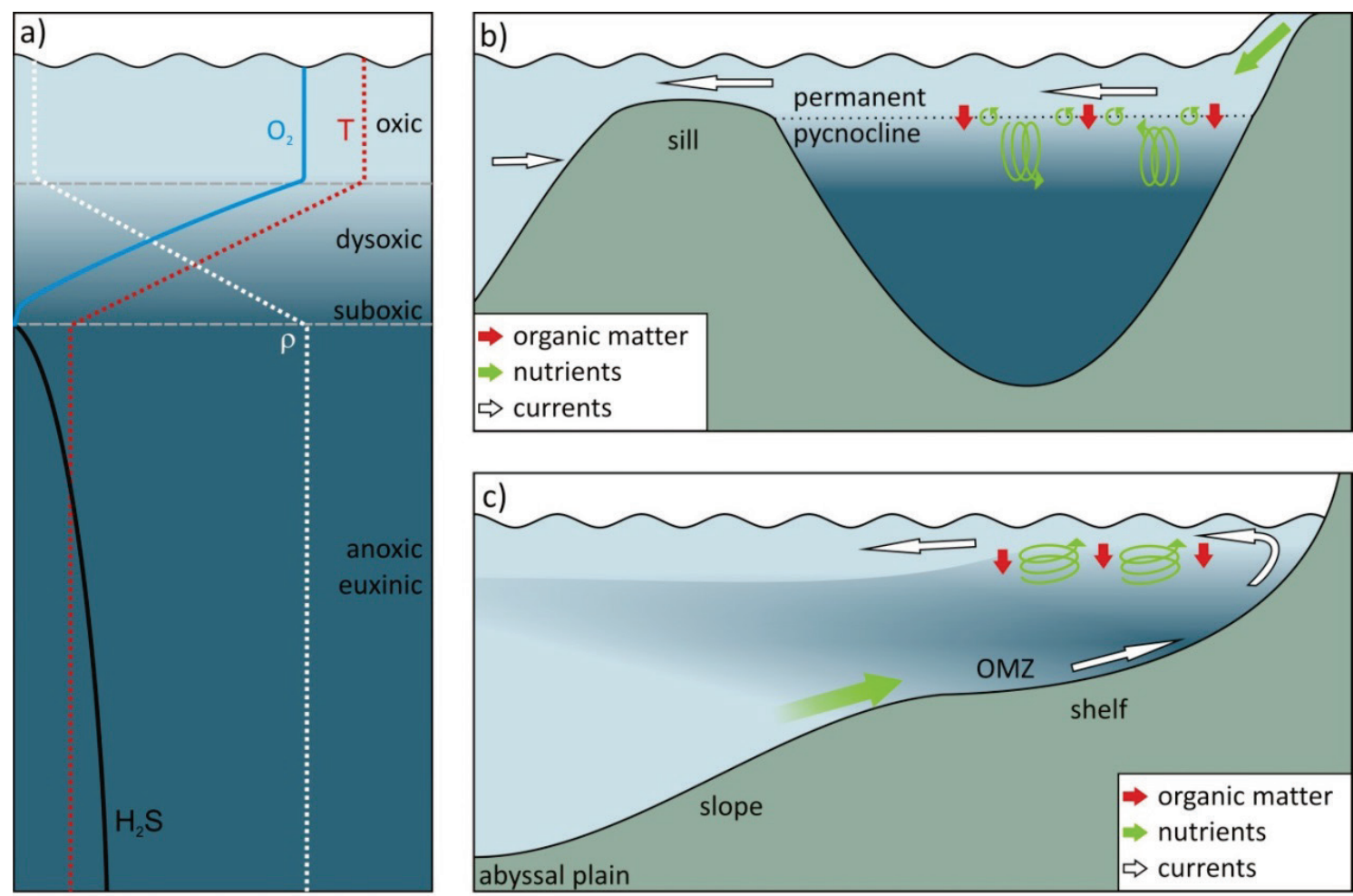

Fig. 3: Physicochemical properties and development of stratified water columns. a) Physicochemical properties of a stratified water column. Warmer water of lower density are overlying cooler, denser deep waters ( $\rho=$ density). Oxygen levels are indicated by color change and notes at the right side (compare Tab. 1). The chemocline (area of steepest gradients) is located between the dashed gray lines. b) A density stratified water column in a silled basin topography. Organic material from a highly productive surface is sinking below the pycnocline and is decomposed under $\mathrm{O}_{2}$ consumption in the isolated deep water layers. Nutrients are trapped below the pycnocline; new nutrients enter the system via e.g. riverine input. c) Formation of a stratified water column under upwelling regions. Nutrient-rich deep water masses are brought into the photic zone, strongly enhancing primary production. Sinking organic material is decomposed under $\mathrm{O}_{2}$ consumption.

Such a chemocline is also occurring in coastal upwelling regions. Modern upwelling is mainly located at western continental margins, e.g. at the Peru and Chile Margin and the coasts of California and Namibia (Strauss, 2006). These areas are naturally rich in nutrients brought up with cold deep waters (Colling et al., 2001), and primary production in these settings is high. Microbial respiration of organic material exported to deeper water layers leads to an oxygen minimum zone (OMZ) and a similar $\mathrm{O}_{2}$ zonation as in the semi-enclosed continental seas (Fig. 3c). The same effect can be observed for monsoon-driven upwelling in the Arabian Sea and the Bay of Bengal (Bange et al., 2000; Helly and Levin, 2004; Strauss, 2006).

Naturally occurring hypoxic conditions, especially in the semi-enclosed continental seas, were enhanced in the last decades by human eutrophication. The resulting planktonic algal blooms and the extensive amounts of organic material fueled 
microbial respiration, which further intensified oxygen consumption and thus, hypoxic environments were spreading (Tyson and Pearson, 1991; Zaitsev and Mamaev, 1997a; Diaz and Rosenberg, 2008). Consequently, habitat compressions and the loss of benthic organisms not only had severe effects for the original flora and fauna, but also negatively affected fishery economies (Zaitsev, 1992; Diaz and Rosenberg, 2008; Meyer and Kump, 2008).

\subsection{Geobiology of stratified water columns}

Stratified water columns comprise many physical and chemical gradients that support different layers of biological activity (Wakeham et al., 2007; Meyer and Kump, 2008). The oxic surface is usually inhabited by a mixed prokaryotic/eukaryotic community, including bacteria, algae, protists, invertebrates and vertebrates. High primary production by microalgae and cyanobacteria in the photic zone leads to nutrient depletion in this water layer and export of organic material to deeper water layers. In settings with a deep photic zone or a shallow chemocline, photosynthetic anoxygenic green and purple sulfur bacteria also contribute to primary production (Overmann et al., 1992; Mandernack et al., 2003, and citations therein). As previously mentioned, a stratified water column means a compressed habitat for organisms that are sensitive to low $\mathrm{O}_{2}$ concentrations and the toxic $\mathrm{H}_{2} \mathrm{~S}$. A sufficient $\mathrm{O}_{2}$ supply thus limits their vertical distribution to oxic water layers (Tyson and Pearson, 1991; Diaz and Rosenberg, 2008). Some protists are more tolerant with respect to $\mathrm{O}_{2}$ and $\mathrm{H}_{2} \mathrm{~S}$. These do not only thrive in oxic layers and the chemocline, but in the case of some grazing ciliates also in anoxic/euxinic layers (Behnke et al., 2006; Anderson et al., 2012; Edgcomb and Pachiadaki, 2014). The chemocline supports a multitude of microbial physiologies because of its steep physicochemical gradients. Various oxidants and reductants co-occur, and especially the lower chemocline is known to be a hotspot of microbial activity (Wakeham et al., 2007; Wakeham et al., 2012; Edgcomb and Pachiadaki, 2014). Important biogeochemical processes in the chemocline are sulfide oxidation and the aerobic oxidation of methane $\left(\mathrm{CH}_{4}\right)$ by $\mathrm{O}_{2}$ consumption, iron (Fe(III)) and manganese (Mn(IV)) reduction, as well as de-nitrification and anaerobic ammonium oxidation (anammox), both leading to the formation of di-nitrogen $\left(\mathrm{N}_{2}\right)$. The high abundance of bacteria and archaea within the chemocline makes it a productive zone with rapid 
turnover of organic material (Detmer et al., 1993). Heterotrophic bacteria and eukaryotes, such as ciliates and dinoflagellates, are also important members of the chemocline microbial community (Detmer et al., 1993; Wakeham et al., 2007; Stock et al., 2009; Anderson et al., 2012; Wakeham et al., 2012; Edgcomb and Pachiadaki, 2014).

The anoxic zone is dominated by archaea and bacteria, although some ciliates are usually found below the chemocline and in case of the Cariaco Basin, even down to $900 \mathrm{~m}$ water depth (Anderson et al., 2012; Edgcomb and Pachiadaki, 2014). The main processes in the anoxic zone are sulfate reduction and anaerobic oxidation of methane (AOM). The reduction of sulfate, which is abundant in sea water, is energetically more favorable than methanogenesis and the presence of sulfate limits methanogenesis. Thus, methanogenesis usually occurs in the underlying sediments in the absence of sulfate.

Benthic macrofauna can only be found under either periodically and short, or persistent hypoxic conditions. In usually oxic environments, where the benthic macrofauna is not adapted to low oxygen concentrations, only episodic hypoxic events in the range of days to weeks can be survived by a few species. Instead, the persistent OMZs below upwelling regions, e.g. Peru Margin, are characterized by high benthic biomass, because species could adapt to the continuously low oxygen and high organic matter environment (Diaz and Rosenberg, 1995, 2008). Persistent and spreading anoxia, however, leads to mass mortalities of benthic macrofauna. Basins such as the Black and Baltic Sea are therefore free of such organisms (Diaz and Rosenberg, 1995; Zaitsev and Mamaev, 1997a, b).

\subsection{Holocene development of the Baltic Sea and the present situation}

The development of the modern stratified Baltic Sea is characterized by a complex interplay of melting glaciers, eustatic and isostatic processes, opening and closing thresholds, and freshwater periods interchanging with brackish periods. The history of the Baltic Sea is divided into the (unstratified) Baltic Ice Lake, Yoldia Sea, Ancylus Sea, and the (stratified) Littorina Sea stages, followed by a Post-Littorina and the present stage. Ages (in calendar years) were taken from Zillén et al. (2008) and Zillén and Conley (2010). It has to be taken into account, that these ages can vary 
depending on the sample location and thus, only reflect a basic time scale. See Fig. 4 for locations mentioned in the text.

\subsubsection{Baltic Ice Lake ( 16,000-11,600 cal. yr. BP)}

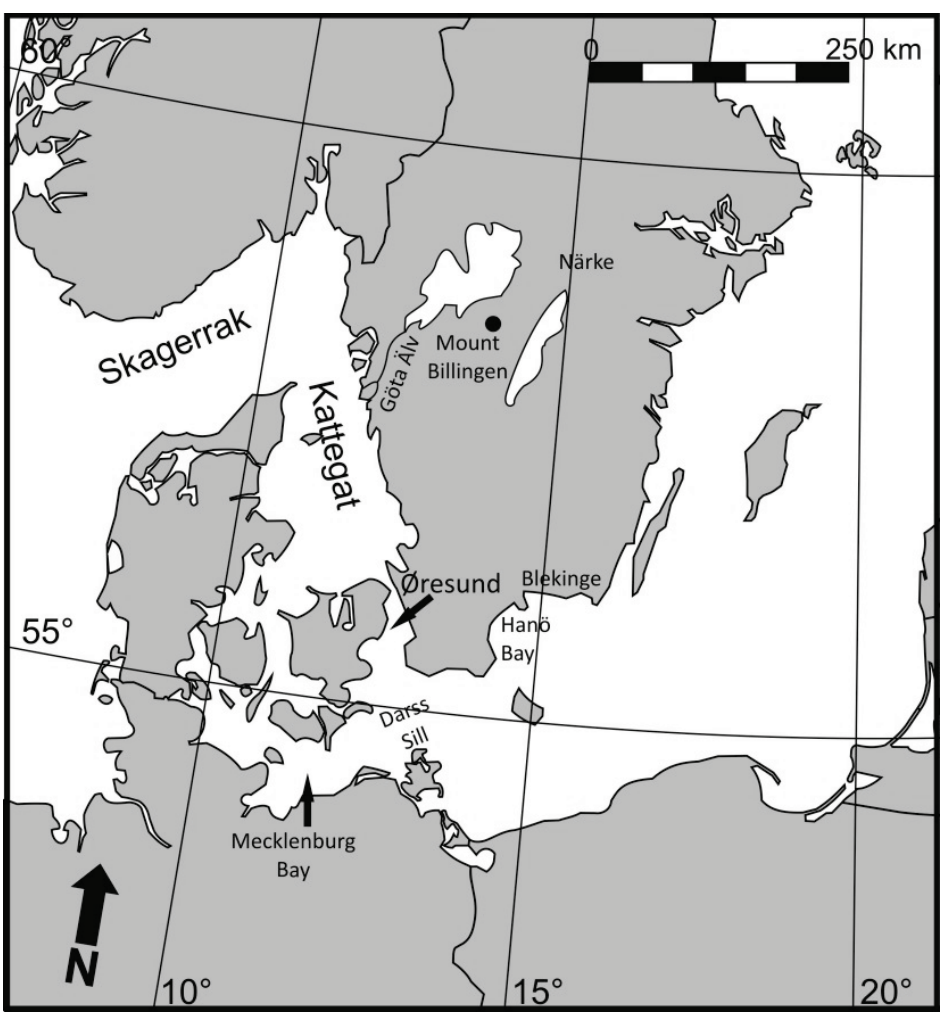

Fig. 4: The south western Baltic Sea with locations mentioned in the text (adapted and changed from Björck, 1995).
The onset of deglaciation in the southwestern Baltic Sea area is dated from $\sim 17,000$ to 15,000 cal. yr. BP, with the formation of a first lake in the Mecklenburg Bay/Hanö Bay region (Björck, 1995; Andrén et al., 2000b). With proceeding melting, large parts of the southern Baltic became ice free and the Baltic Ice Lake developed from $\sim 16,000$ cal. yr. BP on (Zillén et al., 2008), with drainage through the Øresund.

Sediments deposited close to the ice sheet during that time were reddish-brown varved clays. Further away, more homogenous clays were deposited (Björck, 1995; Moros et al., 2002).

Because of isostatic uplift in the ice free regions, the Øresund was successively closed. The Baltic Ice Lake was dammed and the water level rose above sea level. Finally, at $\sim 11,600$ cal. yr. BP, the water drained abruptly at Mount Billingen in south central Sweden and caused water levels to drop up to 25 m (Björck, 1995; Zillén et al., 2008).

\subsubsection{Yoldia Sea ( 11,600-10,700 cal. yr. BP)}

After the Baltic Ice Lake drained, the Yoldia Sea was established and its water level was determined by the global ocean (Zillén et al., 2008). Deglaciation increased and sedimentation rates were high, with exposed formerly Ice Lake clays now being 
reworked. Sediments changed to dark gray clays with thick varves (Björck, 1995; Sohlenius et al., 1996).

In the south central Swedish Lowlands, the Närke Strait opened and connected the Yoldia Sea to the ocean. The continuous outflow of melt water prevented salt water intrusions, until melting slowed down and the global sea level rose (Björck, 1995; Andrén et al., 2000b). A brackish phase of about 200-300 cal. yr. could be tracked (Wastegård et al., 1995), until isostatic uplift closed the Närke Strait and the Yoldia Sea became fresh again (Sohlenius et al., 1996).

\subsubsection{Ancylus Lake ( 10,700-8,000 cal. yr. BP)}

After the closing of the Närke Strait, only a narrow drainage in this area remained, and the Ancylus Transgression was initiated. Again, the water level was dammed above sea level. Because melting glaciers were no longer influencing sedimentation, a homogenous gray clay was deposited rather than varves (Sohlenius et al., 1996).

Main drainage of the Ancylus Lake with a substantial water level drop occurred at 10,000 cal. yr. BP, when the Darss Sill was eroded and a connection to the Kattegat was established (Björck, 1995). The narrow and long connection, however, prevented salt water inflows until $\sim 8,000$ cal. yr. BP, when the global sea level rose above Øresund sill (Björck, 1995). Before the intrusion of salt water, the absence of a halocline and a relatively low deposition of organic matter preserved oxic bottom waters in the entire Ancylus Lake (Sohlenius et al., 1996).

\subsubsection{Littorina Sea ( 8,000 - 4,000 cal. yr. BP)}

The initial Littorina stage began with the first intrusion of salt water and ended when fully brackish conditions were achieved at 6,000 cal. yr. BP (Andrén et al., 2000a; Andrén et al., 2000b; Zillén and Conley, 2010). During this time, the Øresund transect was about twice of its present size (Gustafsson and Westman, 2002). Climate changes reduced river runoff and increased nutrient input into the Littorina Sea (Andrén et al., 2000a). A permanent halocline was established and flora and fauna changed to more marine species (Andrén et al., 2000a). The following Littorina stage was the most marine stage in the history of the Baltic Sea with salinity values as high as 10-15 \%o (modern: 7-8\%; Andrén et al., 2000b; Gustafsson and Westman, 2002; Zillén et al., 2008). The strong pycnocline and the 
increased primary production, dominated by cyanobacteria (Andrén et al., 2000a), most likely lead to hypoxic bottom waters as far north as the Bothnian Sea and Bay (Zillén and Conley, 2010). In the deep central Baltic basins, hypoxic bottom waters probably have been established since the first salt water intrusion (Sohlenius et al., 1996). In these basins, sediments changed to laminated clay gyttja (clay with 6-30\% organic matter) containing pyrite (Sohlenius et al., 1996).

\subsubsection{Post-Littorina Sea ( 4,000-present cal. yr. BP)}

From $\sim 4,000$ cal. yr. BP on, salinity started to drop considerably. The Kattegat connection was reduced in size by isostatically induced sea level changes and less salt water was flowing in (Zillén and Conley, 2010). The flora and fauna shifted back to more freshwater species (Andrén et al., 2000a). Fewer saltwater inflows lead to a weakened pycnocline and the end of anoxia in the northern Baltic Sea. The main physicochemical conditions established during this time have not changed until today and conditions of the basin were very similar to the modern ones (Zillén and Conley, 2010).

From $\sim 2,000$ cal. yr. BP on, warmer climate phases and human activities influenced the Baltic Sea. Warmer climates during Roman (100-400 AD) and Medieval times (1000-1100 AD) lead to increased primary production and hypoxia (Andrén et al., 2000a; Andrén et al., 2000b; Leipe et al., 2008). Growing populations around the Baltic and greater land use during the early-Medieval expansion (800-1300 AD) enhanced these processes (Zillén and Conley, 2010). In contrast to the warmer periods before, a cold phase from 1300-1850 AD (including the Little Ice Age) with reduced salt water inflows and a population decline during the late-Medieval crisis $(\sim 1300$ AD) caused more oxic conditions and a reduced primary production (Leipe et al., 2008; Zillén and Conley, 2010).

Human population growth increased from the $18^{\text {th }}$ century, including a boom which occurred after 1850 with the Industrial Revolution. This change had a considerable impact on the Baltic Sea. Modern agriculture, deforestation and synthetic fertilizers lead to eutrophication of the Baltic Sea and a strong increase in primary production that caused expanding hypoxia which remains today (Jonsson and Carman, 1994; Zillén and Conley, 2010). 


\subsubsection{The modern Baltic Sea circulation}

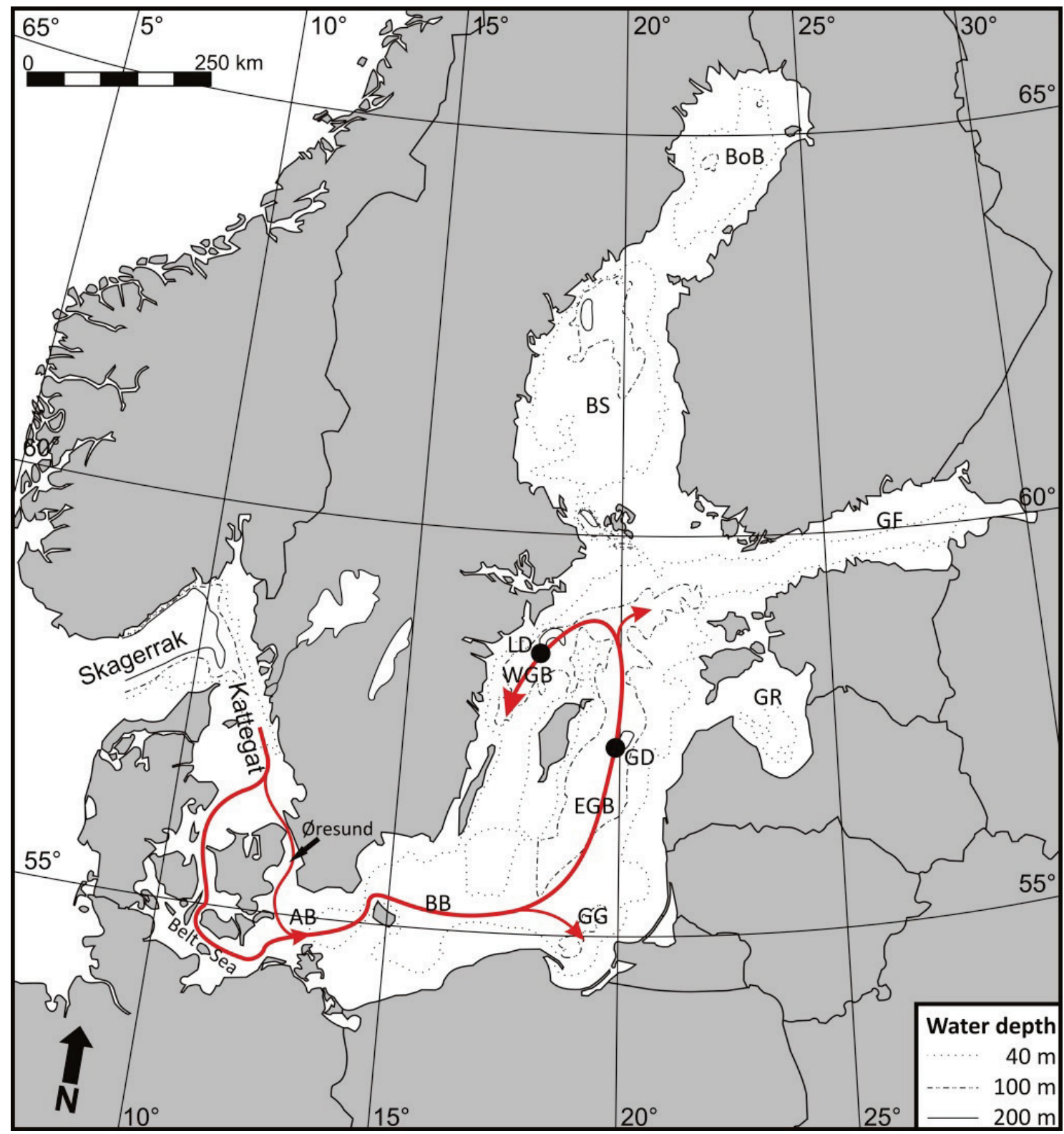

Fig. 5: Map of the Baltic Sea with the modern deep water circulation pathway (red arrows). $A B=$ Arkona Basin; BB = Bornholm Basin; GG = Gulf of Gdansk; EGB = Eastern Gotland Basin; GD = Gotland Deep; GR = Gulf of Riga; $L D=$ Landsort Deep; WGB = Western Gotland Basin; GF = Gulf of Finland; BS = Bothnian Sea; BoB = Bothnian Bay (changed after Matthäus and Lass, 1994; Matthäus and Schinke, 1999)

The modern Baltic Sea circulation is characterized by the narrow and shallow transition area of the Øresund and the Great Belt to the North Sea via Skagerrak and Kattegat that was established during the Post-Littorina-Sea stage (Fig. 5; Matthäus and Schinke, 1999; Reissmann et al., 2009; Zillén and Conley, 2010). Through this transition zone, there is a constant outflow of less saline surface waters, and an inflow of more saline bottom waters. Because of their proximity to the Kattegat 
(surface salinity (dimensionless) $\sim 17$; bottom salinity $\sim 30$ ), salinity is generally higher e.g. in the Arkona and Bornholm Basin (surface 7-10; bottom 20) and Eastern Gotland Basin (surface 7; bottom 12) than in the Western Gotland Basin (surface $\sim 6$; bottom $\sim 10$ ), the Bothnian Sea $(\sim 6)$ and the Bothnian Bay ( 3; Winsor et al., 2001; Stal et al., 2003; Reissmann et al., 2009).

Large amounts of saline waters from the North Sea, however, can only enter the Baltic Sea under very specific meteorological conditions including continuous zonal winds, sea level and density differences (Matthäus and Lass, 1995; Meier et al., 2006; Reissmann et al., 2009). Significant inflows (Major Baltic Inflows, MBIs) were observed in 1993 and another, although considerably smaller with respect to water volume, salinity and oxygenation, in 2003 (Feistel et al., 2006). The inflow of 1993 was able to end a stagnation period in the Eastern Gotland Basin that had continued since 1977 (Matthäus and Lass, 1995), but was not strong enough to have a considerable influence on the deeper water layers of the Western Gotland Basin and the Landsort Deep (Bergström and Matthäus, 1996). The entering saline waters are diluted by turbulent mixing and entrainment of less saline water masses and they ultimately are no longer dense enough to reach more distant basins as bottom currents. Thus, the central Baltic deep waters are only sporadically ventilated (Matthäus and Lass, 1995; Meier et al., 2006). Only such strong MBIs of dense saline waters as the ones from 1993 and 2003 have the potential to propagate through the system of successional sills and basins into the Eastern, and finally, the Western Gotland Basin (Matthäus and Lass, 1995; Matthäus and Schinke, 1999).

\subsection{Sampling and analytical methods}

\subsubsection{Sampling}

Particulate organic carbon (POC) from water column samples includes phytoplankton, zooplankton, bacteria and archaea, but can also contain pollen or other parts of land plants. POC can be sampled either using filters or sediment traps (Fig. 6).

Sediment traps gather sinking particles. Collected POC in these traps reflect an integrated signal of the material derived from the water column above. Thus, sediment traps cannot give information about the exact origin of the POC within the water column and are rather used for the estimation of sediment or surface 
productivity fluxes (Harvey, 2006). Filtering, instead, allows selective sampling of different water depths. As in our studies, POC often is collected using glass fiber filters with certain pore sizes (nominally 0.7 $\mu \mathrm{m})$ and pore sizes thus define the lower size boundary of POC (Harvey, 2006). In the following chapters, water samples were taken with an in situ pump (with the exception of

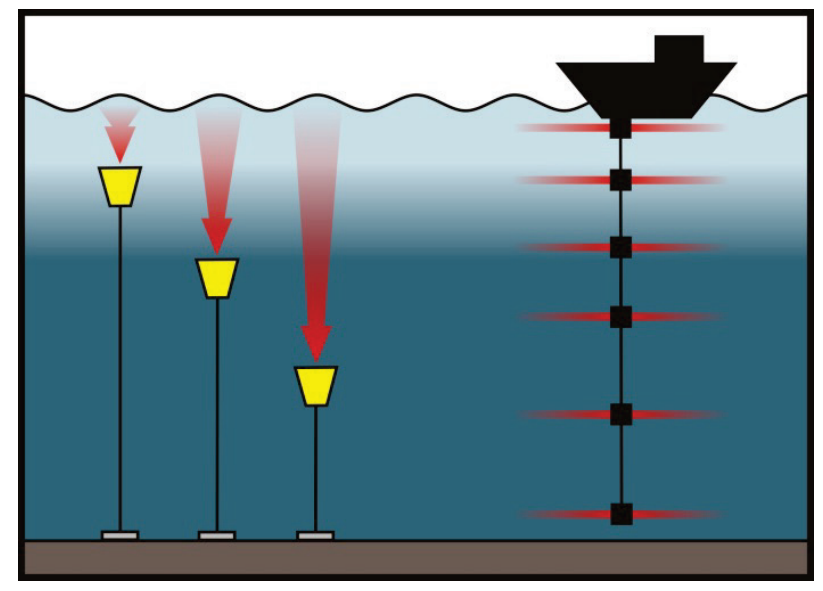

Fig. 6: Sediment trap and in situ pump sampling. Particles sampled with sediment traps (left) are derived from the complete overlying water column. In situ pumping (right) allows sampling of distinct water layers. chapter 3, where samples were taken with a pump-CTD connected to filtration on board). The pump was supplied with a glass fiber filter and remained for several hours in the relevant water depth and filtered up to $\sim 250 \mathrm{l}$. This method allows sampling of distinct water layers within the oxic, suboxic and anoxic zones.

Surface sediments were sampled with a "Frahmlot" that yielded undisturbed surface layers and up to $1 \mathrm{~m}$ of deeper sediments. A gravity corer was used to recover an $11.6 \mathrm{~m}$ long sediment core covering all stages of the Baltic Sea Holocene history.

\subsubsection{Extraction, fractionation and analysis of biomarkers}

For a detailed description of extraction methods, see chapter 2. Briefly, filters and sediment samples were freeze dried. Filters were then cut into small pieces, and sediment samples were homogenized. Both were then extracted three times using a mixture of dichloromethane (DCM)/methanol (MeOH) (3:1; v:v) and a CEM Mars 5 microwave (Matthews, NC, USA). The extracts were combined.

The total extracts were further divided into hydrocarbons, ketones and alcohols, and fatty acids by column chromatography (for exact methods applied, see for example chapter 3). Analysis was done with gas chromatography - mass spectrometry (GCMS). In GC-MS, the compounds of the vaporized sample are separated by a heated capillary column (stationary phase) and a continuous flow of a carrier gas (mobile phase, helium in the case of the following studies). Individual compounds become mobile again depending on the affinity for the stationary phase of the column and 
their relative vapor pressure. The released uncharged molecules become positively ionized and fragmented under high vacuum in the ion source of the mass spectrometer. The ions are accelerated and mass separated in the homogenous magnetic field of the quadrupole mass analyzer. The resulting ion current is intensified and finally detected. In GC-combustion isotope ratio mass spectrometry (GC-C-IRMS), the compounds are combusted and oxidized after column separation. Water is removed from the resulting $\mathrm{CO}_{2}$ before it enters the IRMS. The molecules are ionized, accelerated and mass sorted according to their isotopic composition.

Most BHPs are highly functionalized and too amphiphilic for analysis by GC-MS. GCMS analysis is only possible by the treatment of BHPs with periodic acid (oxidation of the 1,2-diols yielding aldehyde products) and sodium borohydrate (reduction of the aldehyde products to terminal alcohols), but this leads to a loss of structural information of the side chain (Talbot et al., 2001). Thus, BHPs are analyzed by liquid chromatography-mass spectrometry (LC-MS) that allows for identification of complex and highly polar molecules. In LC-MS, a liquid mobile phase with gradually changing polarities is used for mobilization of the compounds from the capillary column instead of the temperature program applied in GC-MS. The sample is vaporized before entry into the mass spectrometer. The molecules become ionized and are processed as described for GC-MS.

\subsection{Introduction to the following chapters}

A comparison of different extraction methods with respect to bacteriohopanepolyols (BHPs) is discussed in Chapter 2 ("Test of microwave, ultrasound and Bligh \& Dyer extraction for quantitative extraction of bacteriohopanepolyols (BHPs) from marine sediments"). All methods are applicable for the extraction of BHPs and microwave extraction was the method preferentially used in the following chapters. [Own contribution: First author; reprocessing of samples, measurements, interpretation, discussion, writing.]

In chapter 3 , the general distribution of biomarkers in the stratified central Baltic Sea water column was analyzed with samples collected in the Landsort Deep ("Biomarkers in the stratified water column of the Landsort Deep (Baltic Sea)"). [Own contribution: First author; reprocessing of samples, measurements, interpretation, discussion, writing.] 
First results on aerobic methanotrophy in the Baltic Sea Gotland Deep are presented in Chapter 4 ("Aerobic methanotrophy within the pelagic redox-zone of the Gotland Deep (central Baltic Sea)"). Interdisciplinary methods performed on water samples collected in summer 2008 gave information about the amount of methane consumed and the bacteria involved in the suboxic zone. [Own contribution: Co-Author; partial reprocessing of samples, contribution to interpretation, discussion, writing.]

In Chapter 5 ("Biomarkers for aerobic methanotrophy in the water column of the stratified Gotland Deep (Baltic Sea)"), Gotland Deep samples collected in summer 2008 were further analyzed with respect to molecular biomarkers. BHPs were of special interest. It was shown that suboxic zone BHP production controls BHP signals in the underlying surface sediment. [Own contribution: First author; reprocessing of samples, measurements, interpretation, discussion, writing.]

The geological record of BHPs in sediments and their applicability to reconstruct water column stratification during the Baltic Sea Holocene history is discussed in chapter 6 ("Bacteriohopanepolyols record stratification, nitrogen fixation and other biogeochemical perturbations in Holocene sediments of the central Baltic Sea"). [Own contribution: Co-Author; partial reprocessing of samples, BHP measurements, contribution to writing.]

\section{References}

Anderson, R., Winter, C., Jürgens, K., 2012. Protist grazing and viral lysis as prokaryotic mortality factors at Baltic Sea oxic-anoxic interfaces. Marine Ecology Progress Series 467, 1-14.

Andrén, E., Andrén, T., Kunzendorf, H., 2000a. Holocene history of the Baltic Sea as a background for assessing records of human impact in the sediments of the Gotland Basin. The Holocene 10, 687-702.

Andrén, E., Andrén, T., Sohlenius, G., 2000b. The Holocene history of the southwestern Baltic Sea as reflected in a sediment core from the Bornholm Basin. Boreas 29. 
Bange, H.W., Rixen, T., Johansen, A.M., Siefert, R.L., Ramesh, R.L., Ittekott, V., Hoffmann, M.R., Andreae, M.O., 2000. A revised nitrogen budget for the Arabian Sea. Global Biogeochemical Cycles 14, 1283-1297.

Behnke, A., Bunge, J., Barger, K., Breiner, H.-W., Alla, V., Stoeck, T., 2006. Microeukaryote community patterns along an $\mathrm{O}_{2} / \mathrm{H}_{2} \mathrm{~S}$ gradient in a supersulfidic anoxic fjord (Framvaren, Norway). Applied and Environmental Microbiology 72, 3626-3636.

Bergström, S., Matthäus, W., 1996. Meteorology, hydrology and hydrography. In: Third periodic assessment of the state of the marine environment of the Baltic Sea, 1989-1993; Background document HELCOM, Helsinki.

Berry, A.M., Moreau, R.A., Jones, A.D., 1991. Bacteriohopanetetrol: abundant lipid in Frankia cells and in nitrogen-fixing nudule tissue. Plant Physiology 95, 111-115.

Björck, S., 1995. A review of the history of the Baltic Sea, 13.0-8.0 ka BP. Quaternary International 27, 19-40.

Blumenberg, M., Hoppert, M., Krüger, M., Dreier, A., Thiel, V., 2012. Novel findings on hopanoid occurrences among sulfate reducing bacteria: Is there a direct link to nitrogen fixation? Organic Geochemistry 49, 1-5.

Blumenberg, M., Oppermann, B.I., Guyoneaud, R., Michaelis, W., 2009. Hopanoid production by Desulfovibrio bastinii isolated from oilfield formation water. FEMS Microbiology Letters 293, 73-78.

Brocks, J.J., Grice, K., 2011. Biomarkers (molecular fossils). In: Reitner, J., Thiel, V., Encyclopedia of Geobiology. Springer, Dordrecht, The Netherlands, pp. 147-167.

Brocks, J.J., Pearson, A., 2005. Building the biomarker tree of life. Reviews in Mineralogy and Geochemistry 59, 233-258.

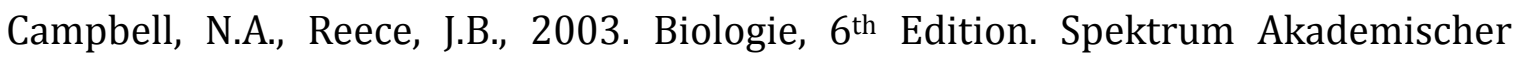
Verlag, Heidelberg, Berlin. 
Colling, A., Brown, E., Park, D., Philips, J., Rothery, D., Wright, J., 2001. Ocean Circulation. Butterworth Heinemann, Oxford.

Detmer, A.E., Giesenhagen, H.C., Trenkel, V.M., Auf dem Venne, H., Jochem, F., 1993. Phototrophic and hetreotrophic pico- and nanoplankton in anoxic depths of the central Baltic Sea. Marine Ecology Progress Series 99, 197-203.

Diaz, R.J., Rosenberg, R., 1995. Marine benthic hypoxia: a review of its ecological effects and the behavioural responses of benthic macrofauna. Oceanography and Marine Biology: an annual Review 33, 245-303.

Diaz, R.J., Rosenberg, R., 2008. Spreading dead zones and consequences for marine ecosystems. Science 321, 926-929.

Edgcomb, V.P., Pachiadaki, M., 2014. Ciliates along oxyclines or permanently stratified marine water columns. Journal of Eukaryotic Microbiology 0, 1-12.

Feistel, R., Nausch, G., Hagen, E., 2006. Unusual Baltic inflow activity in 2002-2003 and varying deep-water properties. Oceanologia 48, 21-35.

Gustafsson, B.G., Westman, P., 2002. On the causes of salinity variations in the Baltic Sea during the last 8500 years. Paleoceanography 17, 12-11-12-14.

Harvey, H.R., 2006. Sources and cycling of organic matter in the marine water column. In: Volkmann, J.K., The handbook of environmental chemistry, Volume 2: Marine organic matter. Springer, Berlin, Heidelberg, pp. 1-25.

Helly, J.J., Levin, L.A., 2004. Global distribution of naturally occurring marine hypoxia on continental margins. Deep-Sea Research I 51, 1159-1168.

Jonsson, P., Carman, R., 1994. Changes in deposition of organic matter and nutrients in the Baltic Sea during the twentieth century. Marine Pollution Bulletin 28, 417-426.

Kannenberg, E.L., Poralla, K., 1999. Hopanoid biosythesis and function in bacteria. Naturwissenschaften 86, 168-176.

Konhauser, K., 2007. Introduction to Geomicrobiology. Blackwell Publishing, Oxford. 
Konovalov, S.K., Murray, J.W., Luther III, G.W., 2005. Basic processes of Black Sea biogeochemistry. Oceanography 18, 24-35.

Leipe, T., Dippner, J.W., Hille, S., Voss, M., Christiansen, C., Bartholdy, J., 2008. Environmental changes in the central Baltic Sea during the past 1000 years: inferences from sedimentary records, hydrography and climate. Oceanologia 50, 2341.

Mandernack, K.W., Krouse, H.R., Skei, J.M., 2003. A stable sulfur and oxygen isotopic investigation of sulfur cycling in an anoxic marine basin, Framvaren Fjord, Norway. Chemical Geology 195, 181-200.

Matthäus, W., Lass, H.U., 1995. The recent salt inflow into the Baltic Sea. Journal of Physical Oceanography 25, 280-286.

Matthäus, W., Schinke, H., 1999. The influence of river runoff on deep water conditions of the Baltic Sea. Hydrobiologia 393, 1-10.

Meier, H.E.M., Feistel, R., Piechura, J., Arneborg, L., Burchard, H., Fiekas, V., Golenko, N., Kuzmina, N., Mohrholz, V., Nohr, C., Paka, V.T., Sellschopp, J., Stips, A., Zhurbas, V., 2006. Ventilation of the Baltic Sea deep water: A brief review of present knowledge from observations and models. Oceanologia 48, 133-164.

Meyer, K.M., Kump, L.R., 2008. Oceanic euxinia in earth history: causes and consequences. Annual Review of Earth and Planetary Sciences 36, 251-288.

Moros, M., Lemke, W., Kuijpers, A., Endler, R., Jensen, J.B., Bennike, O., Gingele, F., 2002. Regressions and transgressions of the Baltic basin refelcted by a new hoghresolution deglacial and postglacial lithostratigraphy for Arkona Basin sediments (western Baltic Sea). Boreas 31, 151-162.

Neunlist, S., Rohmer, M., 1985. Novel hopanoids from the methylotrophic bacteria Methylococcus capsulatus and Methylomonas methanica. (22S)-35aminobacteriohopane-30,31,31,33,34-pentol and (22S)-35-amino-3 $\beta$ methylbacteriohopane-30,31,32,33,34-pentol. Biochemical Journal 231, 635-639. 
Ourisson, G., Albrecht, P., 1992. Hopanoids. 1. Geohopanoids: The most abundant natural products on earth? Accounts of Chemical Research 25, 398-402.

Overmann, J., Cypionka, H., Pfennig, N., 1992. An extremely low-light-adapted phototrophic sulfur bacterium from the Black Sea. Limnology and Oceanography 37, 150-155.

Pancost, R.D., Pagani, M., 2006. Controls on the carbon isotopic compositions of lipids in marine environments. In: Volkman, J.K., The handbook of environmental chemistry, Volume 2: Marine organic matter. Springer, Berlin, Heidelberg, pp. 209249.

Pearson, A., Flood Page, S.R., Jorgensen, T.L., Fischer, W.W., Higgins, M.B., 2007. Novel hopanoid cyclases from the environment. Environmental Microbiology 9, 2175-2188.

Peters, K.E., Walters, C.C., Moldowan, J.M., 2004. The biomarker guide, Volume 1, $2^{\text {nd }}$ Edition. Cambridge University Press, Cambridge.

Reissmann, J.H., Burchard, H., Feistel, R., Hagen, E., Lass, H.U., Mohrholz, V., Nausch, G., Umlauf, L., Wieczorek, G., 2009. State-of-the-art review on vertical mixing in the Baltic Sea and consequences for eutrophication. Progress in Oceanography 82, 4780 .

Rohmer, M., Bouvier-Nave, P., Ourisson, G., 1984. Distribution of hopanoid triterpenes in prokaryotes. Journal of General Microbiology 130, 1137-1150.

Sohlenius, G., Sternbeck, J., Andrén, E., Westman, P., 1996. Holocene history of the Baltic Sea as recorded in a sediment core from the Gotland deep. Marine Geology 134.

Stal, L.J., Albertano, P., Bergmann, B., von Bröckel, K., Gallon, J.R., Hayes, P.K., Sivonen, K., Walsby, A.E., 2003. BASIC: Baltic Sea cyanobacteria. An investigation of the structure and dynamics of water blooms of cyanobacteria in the Baltic Sea responses to a changing environment. Continental Shelf Research 23, 1695-1714. 
Stock, A., Jürgens, K., Bunge, J., Stoeck, T., 2009. Protistan diversity in suboxic and anoxic waters of the Gotland Deep (Baltic Sea) as revealed by $18 \mathrm{~S}$ rRNA clone libraries. Aquatic Microbial Ecology 55, 267-284.

Strauss, H., 2006. Anoxia through time. In: Neretin, L.N., Past and Present Water Column Anoxia. Springer Netherlands, pp. 3-19.

Talbot, H.M., Watson, D.F., Murrel, J.C., Carter, J.F., Farrimond, P., 2001. Analysis of intact bacteriohopanepolyols from methanotrophic bacteria by reversed-phase highperformance liquid chromatography-atmospheric pressure chemical ionisation mass spectrometry. Journal of chromatography A 921, 175-185.

Tyson, R.V., Pearson, T.H., 1991. Modern and ancient continental shelf anoxia: an overview. Geological Society Special Publication 58, 1-24.

Wakeham, S.G., Amann, R., Freeman, K.H., Hopmans, E.C., Jørgensen, B.B., Putnam, I.F., Schouten, S., Sinninghe Damsté, J.S., Talbot, H.M., Woebken, D., 2007. Microbial ecology of the stratified water column of the Black Sea as revealed by a comprehensive biomarker study. Organic Geochemistry 38, 2070-2097.

Wakeham, S.G., Turich, C., Schubotz, F., Podlaska, A., Xiaona, N.L., Varela, R., Astor, Y., Sáenz, J.P., Rush, D., Sinninghe Damsté, J.S., Summons, R.E., Scranton, M.I., Taylor, G.T., Hinrichs, K.U., 2012. Biomarkers, chemistry and microbiology show chemoautotrophy in a multilayer chemocline in the Cariaco Basin. Deep Sea Research Part I 163, 133-156.

Wastegård, S., Andrén, T., Sohlenius, G., Sandgren, P., 1995. Different phases of the Yoldia Sea in the North-Western Baltic proper. Quaternary International 27, 121129.

Winsor, P., Rodhe, J., Omstedt, A., 2001. Baltic Sea ocean climate: an analysis of 100 yr of hydrographic data with focus on the freshwater budget. Climate Research 18, 5-15.

Zaitsev, Y.P., 1992. Recent changes in the trophic structure of the Black Sea. Fisheries Oceanography 1, 180-189. 
Zaitsev, Y.P., Mamaev, V., 1997a. Main man-made impacts on Black Sea Biodiversity. In, Biological diversity in the Black Sea: a study of change and decline. United Nations Publications, New York, pp. 49-74.

Zaitsev, Y.P., Mamaev, V., 1997b. Present state of Black Sea Biodiversity. In, Biological diversity in the Black Sea: a study of change and decline. United Nations Publications, New York, pp. 75-130.

Zillén, L., Conley, D.J., 2010. Hypoxia and cyanobacteria blooms - are they really natural features of the late Holocene history of the Baltic Sea? Biogeosciences 7, 2567-2580.

Zillén, L., Conley, D.J., Andrén, T., Andrén, E., Björck, S., 2008. Past occurrences of hypoxia in the Baltic Sea and the role of climate variability, environmental chnage and human impact. Earth-Science Reviews 91, 77-92. 


\title{
Test of microwave, ultrasound and Bligh \& Dyer extraction for quantitative extraction of bacteriohopanepolyols (BHPs) from marine sediments
}

\author{
Christine Berndmeyer, Volker Thiel and Martin Blumenberg \\ Organic Geochemistry (2014) 68, 90-94.
}

DOI: 10.1016/j.orggeochem.2014.01.003; reprinted with permission of Elsevier

\subsection{Abstract}

Microwave, ultrasound and Bligh \& Dyer extraction methods were tested for the yield of bacteriohopanepolyols (BHPs) from sediments and their potential to bias compound distributions. Differences in the concentration of abundant BHPs were not apparent for the three methods. However, the two phase solvent Bligh \& Dyer extraction method generally showed greater extraction efficiency for minor BHPs containing an amino group. Our comparison demonstrates that all three methods are suitable for the extraction of BHPs, but quantitative comparisons of individual compounds between studies using different extraction approaches may be biased due to different extraction efficiency for amino BHPs.

\subsection{Introduction}

Bacteriohopanepolyols (BHPs) are increasingly used because of their potential in paleoreconstruction and for the characterization of viable bacterial communities (e.g. Farrimond et al., 2000; Blumenberg et al., 2007, 2009, 2013; Talbot and Farrimond, 2007; Wakeham et al., 2007; Sáenz et al., 2011a; Berndmeyer et al., 2013). A number of methods have been applied to extract BHPs from sediments, microbial cells and other geobiological samples, those based on single phase solvent mixtures [usually dichloromethane (DCM) and $\mathrm{MeOH}$ ] being particularly common. For example, single phase solvent mixtures are used in combination with microwave extraction (Schmidt et al., 2010; Berndmeyer et al., 2013; Blumenberg et al., 2013) or in combination with ultrasound and/or temperature (e.g. Talbot et al., 2003a,b; 
Sinninghe Damste et al., 2004; Blumenberg et al., 2009). Another widely used method for the extraction of BHPs is the so called Bligh \& Dyer extraction (Bligh and Dyer, 1959) using a monophase mixture for extraction consisting of $\mathrm{CHCl}_{3}$ (or DCM), $\mathrm{MeOH}$ and water or phosphate- buffered water, followed by a two phase separation to produce the organic extract (Summons et al., 1994; Jahnke et al., 1999; Cooke et al., 2008, 2009; Rethemeyer et al., 2010; Sáenz et al., 2011a, 2012; Doğrul Selver et al., 2012; Kharbush et al., 2013). For many widely used biomarkers, like intact polar lipids (IPLs) or fatty acids, there are comparative investigations of the extraction efficiency of different methods (e.g. Macnaughton et al., 1997; Lewis et al., 2000; Iverson et al., 2001; Blyth et al., 2006; Jansen et al., 2006; Péres et al., 2006; Huguet et al., 2010), but this is lacking for BHPs. In this study, we have compared the widely used single solvent mixture of $\mathrm{DCM} / \mathrm{MeOH}$, supported by microwave and ultrasound, respectively, with the common Bligh \& Dyer method. We focus on the differences in extraction efficiency and effect on the relative abundance of individual BHPs.

\subsection{Methods}

Two samples from the Baltic Sea Gotland Deep (sample 1) and Landsort Deep (sample 2; both 6-8 $\mathrm{cm}$ sediment depth), collected in summer 2011, were freeze dried and homogenized. Each was divided into $3 \mathrm{~g}$ aliquots and extracted using: (i) microwave extraction, (ii) ultrasound extraction (both using a single phase solvent mixture) and (iii) a modified Bligh \& Dyer extraction using a monophase solvent mixture for extraction followed by a two phase separation.

\subsubsection{Microwave extraction}

The two samples were extracted $3 \mathrm{x}$ with a single phase mixture of $\mathrm{DCM} / \mathrm{MeOH}$ (40 ml; 3:1, v:v) in a CEM Mars 5 device (Matthews, NC, USA). The microwave was operated at $800 \mathrm{~W}$ as follows: heating to $60{ }^{\circ} \mathrm{C}$ over $10 \mathrm{~min}$, extraction for $15 \mathrm{~min}$, cooling to room temperature over $20 \mathrm{~min}$. The combined extracts were dried under reduced pressure at $40^{\circ} \mathrm{C}$ using a rotary evaporator. 


\subsubsection{Ultrasound extraction}

The two samples were extracted with a single phase DCM/MeOH mixture $(40 \mathrm{ml}$, $3: 1, \mathrm{v}: \mathrm{v}$ ) and sonicated (3 $\times 15 \mathrm{~min}$ ) in a water bath (room temperature) with a BANDELIN Sonorex digital 10P (Bandelin Electronics, Berlin, Germany). After centrifugation (20 min, $2000 \mathrm{rpm}$ ), the combined extracts were dried as above.

\subsubsection{Modified Bligh \& Dyer extraction}

The extraction was carried out as described by White and Ringelberg (1998), except that $\mathrm{CHCl}_{3}$ was replaced with DCM, as increasingly done in recent studies (Rashby et al., 2007; Pearson et al., 2008; Saenz et al., 2011a,b, 2012; Sessions et al., 2013). DCM has very similar properties to $\mathrm{CHCl}_{3}$, but is less toxic; $11.4 \mathrm{ml}$ of MeOH/DCM/phosphate buffer (2:1:0.8, v:v; phosphate buffer: $8.7 \mathrm{~g} \mathrm{~K}_{2} \mathrm{HPO}_{4}$ in $1 \mathrm{l}$ nanopure water, adjusted to $\mathrm{pH} 7.4$ with $6 \mathrm{~N} \mathrm{HCl}$ ) were added to the samples and the mixture was sonicated in an ultrasonic bath (30 s only, so as not to bias via intensive ultrasonication). Samples were then shaken on a shaker table for $60 \mathrm{~min}$. They were centrifuged (30 min, $2000 \mathrm{rpm}$ ) and the supernatant decanted into a separating funnel. DCM and water were added to a final ratio of 1:1:0.9 MeOH/DCM/buffer. The separating funnel was vigorously shaken and the aqueous ( $\mathrm{MeOH}$ and water) phase and organic phase (DCM) were allowed to separate overnight. The lower DCM phase was obtained and dried as above.

\subsubsection{Acetylation and liquid chromatography-mass spectrometry (LC-MS)}

The extracts were acetylated using $2 \mathrm{ml} \mathrm{Ac} 2 \mathrm{O}$ and pyridine $(1: 1, \mathrm{v}: \mathrm{v})$ for $1 \mathrm{~h}$ at $50{ }^{\circ} \mathrm{C}$ and left overnight at room temperature. LC-MS was performed using a Prostar Dynamax high performance LC (HPLC) system coupled to a 1200L triple quadrupole mass spectrometry (MS) instrument (both Varian) equipped with a Merck Lichrocart [Lichrosphere 100; reversed phase (RP) $\mathrm{C}_{18 \mathrm{e}}$ column $(250 \times 4 \mathrm{~mm})$ ] and a Merck Lichrosphere pre-column of the same material. A solvent gradient profile of 100\% A [MeOH/water (9:1v:v), 0-1 min] to 100\% B [MeOH/propan-2-ol (1:1, v:v)] at $35 \mathrm{~min}$, then isocratic to $60 \mathrm{~min}$ was used. All solvents were HPLC grade (Fisher Scientific). The LC-MS instrument was operated with an atmospheric pressure chemical ionization (APCI) source in positive ion mode (capillary $150{ }^{\circ} \mathrm{C}$, vaporizer $400{ }^{\circ} \mathrm{C}$, corona discharge $8 \mu \mathrm{A}$, nebulizing flow 70 psi and auxiliary gas 17 psi). For 
determination of concentration, peak areas of selected ions (SIM mode; bacteriohopane-32,33,34,35-tetrol, $m / z$ 655; 32,35-anhydrobacteriohopanetetrol, $m / z \quad 613 ; \quad 35$-aminobacteriohopane-32,33,34-triol, $m / z \quad 714 ; \quad 35$ aminobacteriohopane-31,32,33,34-tetrol, $\quad m / z \quad 772 ; \quad 35$-aminobacteriohopane30,31,32,33,34-pentol, $m / z$ 830; bacteriohopanetetrol cyclitol ether, $m / z$ 1002, after Talbot et al., 2008) were compared with an acetylated authentic BHT and 35aminobacteriohopanetriol standard with known concentrations (external calibration). Amino BHPs had a 7x higher response factor than non-amino BHPs and concentrations in the samples were corrected accordingly. Comparisons with elution times of previously identified compounds were used for BHP assignment. Concentration was corrected for individual responses of amino and non-amino BHPs. Each aliquot was measured 5x.

\subsection{Results}

All three extraction methods resulted in similar amounts of total BHPs for both

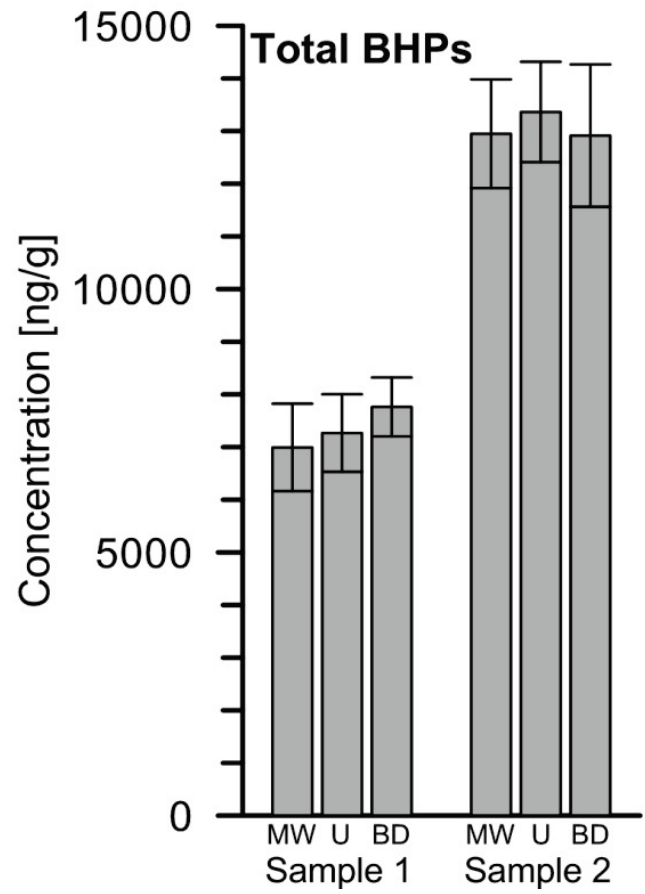

Fig. 1: Summed concentration of BHPS extracted from two Baltic Sea sediments using microwave (MW), ultrasound (U) and Bligh \& Dyer (BD), respectively. Error bars represent standard deviation of the five replicate LC-MS measurements. samples (Fig. 1) with generally higher summed BHP concentration for sample 2 (sample 1: 7.0$7.8 \mu \mathrm{g} / \mathrm{g}$; sample 2: 12.9-13.4 $\mu \mathrm{g} / \mathrm{g})$. The differences appeared to be related to differences in the organic carbon contents $(2.7 \%$ in sample $1,5.8 \%$ in sample 2 ).

In total, eight individual BHPs were found in both samples (for structures, see Fig. 2), namely two isomers of $17 \beta, 21 \beta$-bacterioho- pane32,33,34,35-tetrol (BHT and BHT II), 32,35anhydrobacteriohopanetetrol (anhydroBHT), two isomers of bacteriohopanetetrol cyclitol ether (BHT cyclitol ether and BHT cyclitol ether II), 35-aminobacteriohopane-32,33,34-triol (aminotriol), 35-aminobacteriohopane-

31,32,33,34-tetrol (aminotetrol) and 35aminobacteriohopane-30,31,32,33,34-pentol (aminopentol). 


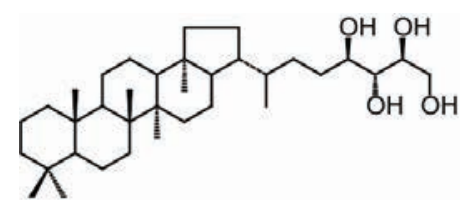

$\mathrm{BHT}$ (and BHT II)

(173,213-bacteriohopane32,33,34,35-tetrol)

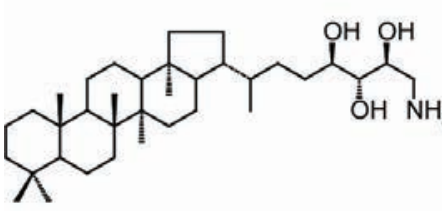

aminotriol (35-aminobacteriohopane-32,33,34-triol)
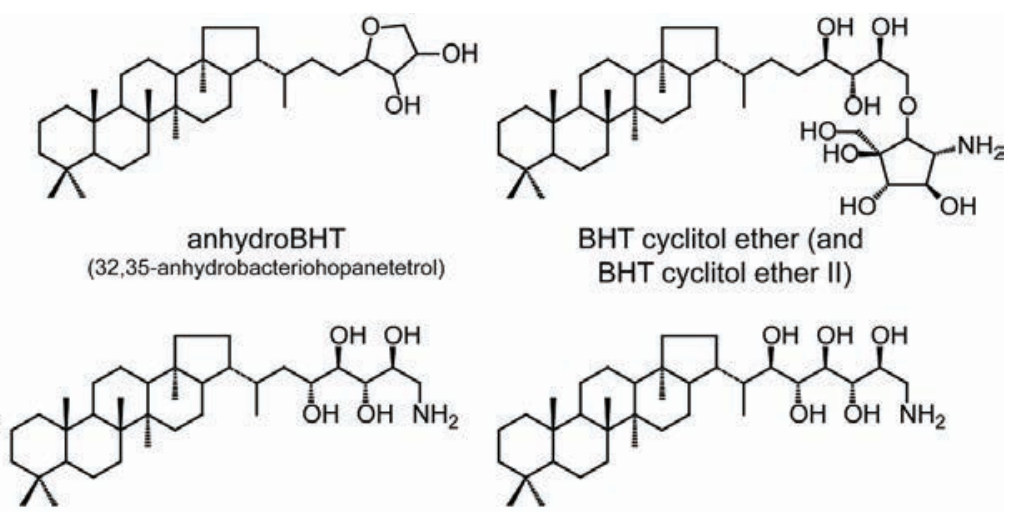

aminotetrol aminopentol

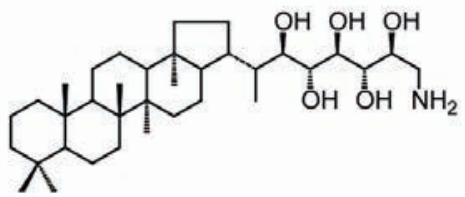

(35-aminobacteriohopane-30,31,32,33,34-pentol)

Fig. 2: BHP structures. The structures of the isomers BHT II and BHT cyclitol ether II were not further characterized.

For both samples, BHT extraction yield from the different methods was almost equal, considering the three error ranges of the individual BHT concentrations (Fig. 3). A higher BHT II concentration was consistently observed with the Bligh \& Dyer extraction (sample 1: microwave $144 \mathrm{ng} / \mathrm{g}$, ultrasound

131 ng/g; Bligh \& Dyer 283 ng/g; sample 2: microwave 685 ng/g, ultrasound 841 ng/g, Bligh \& Dyer 963 ng/g). Furthermore, the concentration of anhydroBHT in sample 2 was similar for all methods (microwave $76 \mathrm{ng} / \mathrm{g}$, ultrasound $78 \mathrm{ng} / \mathrm{g}$, Bligh \& Dyer $67 \mathrm{ng} / \mathrm{g}$ ), but for sample 1, was almost twice as high for the microwave and ultrasound extractions vs. the Bligh \& Dyer extraction (microwave $84 \mathrm{ng} / \mathrm{g}$, ultrasound 73 ng/g, Bligh \& Dyer 44 ng/g). For the less abundant amino BHPs, greater differences were noted. For both samples, BHT cyclitol ether yield from the Bligh \& Dyer extraction was 100-400\% higher than for microwave and ultrasound extraction. Again, the differences were not consistent between the two samples, as the Bligh \& Dyer extraction showed a higher extraction efficiency over the other methods for BHT cyclitol ether II in sample 2 as compared with sample 1 (Fig. 3). A much higher yield from the Bligh \& Dyer extraction was also observed for the 35amino BHPs (aminotriol, aminotetrol and aminopentol) in both samples.

\subsection{Discussion}

While the microwave and the ultrasound extraction use energy in the form of either temperature or ultrasound for enhanced extraction, the Bligh \& Dyer extraction is less intensive. Nevertheless, the total concentration of BHPs was almost constant (Fig. 1), supporting a general capability of all approaches for the extraction of BHPs. 

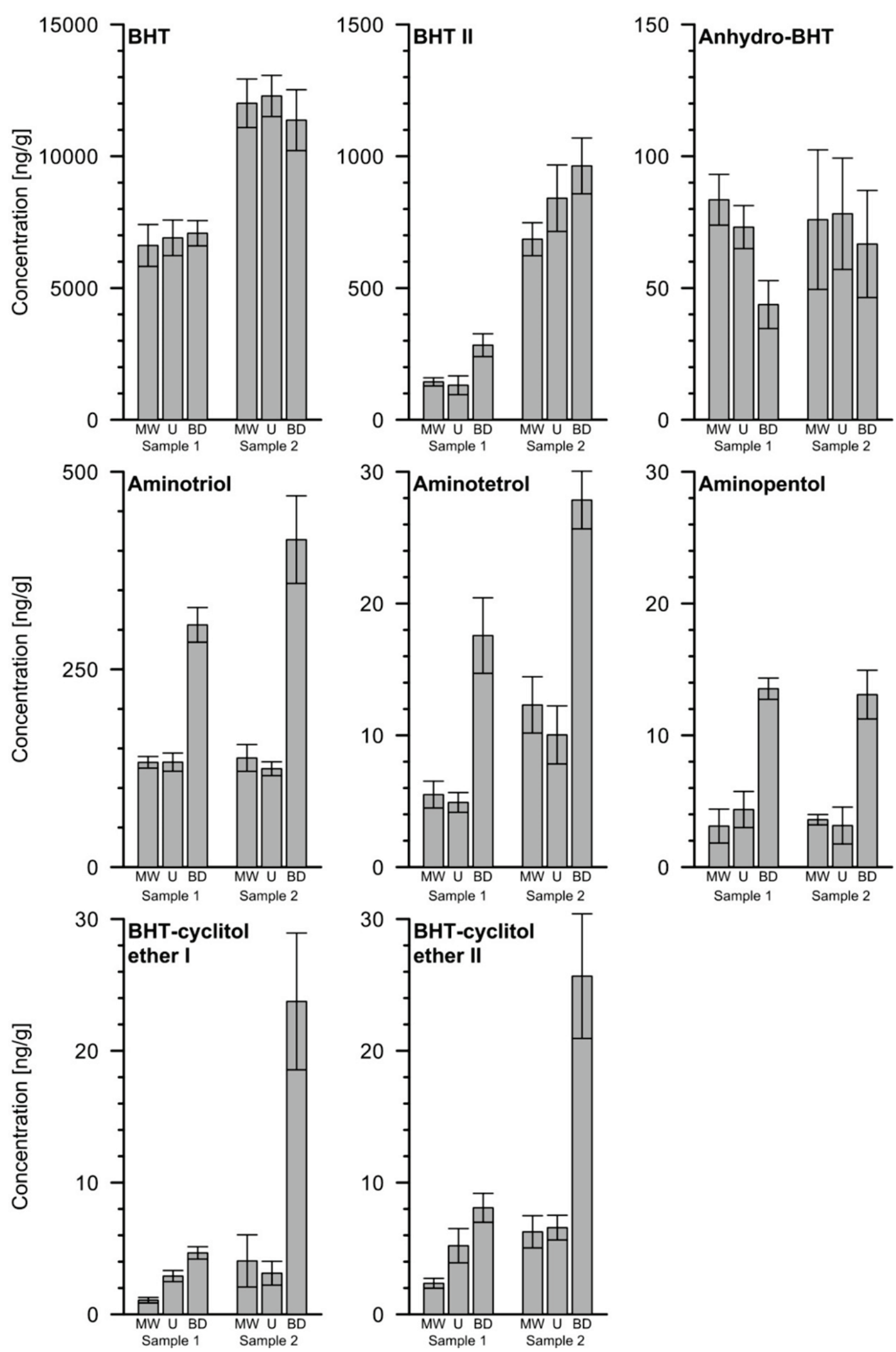

Fig. 3: Concentration of individual BHPs extracted from two Baltic Sea sediments using microwave (MW), ultrasound $(\mathrm{U})$ and Bligh \& Dyer (BD), respectively. Error bars represent standard deviation of the five replicate LC-MS measurements. 
However, differences in the three methods became evident. Visually, the extracts from the microwave and the ultrasound extractions appeared to contain much more organic material (black color, thick and oily appearance). In contrast, the extracts from the Bligh \& Dyer extraction were golden in color. Differences were also obvious in the LC chromatograms, as the peaks were sharper and the noise was considerably lower for the Bligh \& Dyer samples in agreement with a previous study comparing Bligh \& Dyer extraction with a number of other procedures (Cooke, 2011). Thus, in contrast to Bligh \& Dyer, the more energy intensive microwave and ultrasound methods obviously led to extraction of much more, non-LC amenable material.

The concentration of BHT showed only minor variation. The isomer BHT II appeared, however, to be slightly more efficiently extracted with Bligh \& Dyer (Fig. 3). Interestingly, it appeared that BHT II showed an improved signal with the Bligh \& Dyer extraction, as the LC-MS peak shapes were much cleaner and sharper (signal to noise ratio for BHT II: sample 1: microwave 13, ultrasound 12, Bligh \& Dyer 19; sample 2: microwave 30, ultrasound 28, Bligh \& Dyer 37) and the separation between BHT and BHT II was much clearer than for the other methods. Concentration of anhydroBHT was similar for all three methods with sample 2, considering the error range of the individual concentration, but was elevated for microwave and ultrasound extraction of sample 1 (Fig. 3). AnhydroBHT is assumed to be a product of other BHPs, formed during early diagenesis (Talbot et al., 2005; Schaeffer et al., 2008, 2010). Our results raise the question as to whether the more energetic extraction methods (microwave and ultrasound) can lead to the formation of anhydroBHT during extraction. Schaeffer et al. $(2008,2010)$ have shown that anhydroBHT is formed under low $\mathrm{pH}$, as induced by the presence of acidic clay minerals such as montmorillonite and high temperature. Montmorillonite is the dominating clay mineral in the sediments of the northern and middle Baltic proper (Carman and Rahm, 1997), where the samples from the Gotland and Landsort Deep were taken. Thus, the sediment matrix provided favorable conditions for the formation of anhydroBHT in our samples. Schaeffer et al. $(2008,2010)$ treated their samples for $3 \mathrm{~h}$ and 8 days, respectively, in the presence of montmorillonite at $120^{\circ} \mathrm{C}$. Although significant amounts of anhydroBHT were generated from BHT and BHT cyclitol ether after 8 days, only trace amounts of anhydroBHT were found after $3 \mathrm{~h}$. The microwave method, where the highest anhydroBHT concentration was 
found, only uses a temperature of up to $60{ }^{\circ} \mathrm{C}$ for $15 \mathrm{~min}$. Therefore, it is unlikely that anhydroBHT was formed from other BHPs during extraction.

Regarding extraction of the 35-amino BHPs (aminotriol, aminotetrol and aminopentol), an advantage of the Bligh \& Dyer method became obvious. Although the concentrations of these minor compounds obtained with microwave and ultrasound extraction were reproducible for both samples, the yield was much higher with the Bligh \& Dyer extraction. Similar concentration differences were observed for the BHT cyclitol ethers I and II, which also contain an amino group (Renoux and Rohmer, 1985). At this point, however, we can only speculate about the possible reasons for this observation. The possibility of amino BHP destruction by relatively harsh (microwave and ultrasound) extraction methods seems unlikely, as studies have shown that aminotriol does not decompose after $4 \mathrm{~h}$ acid treatment at $120^{\circ} \mathrm{C}$ (Schaeffer et al., 2008). On the other hand, the solvent mixture in the Bligh \& Dyer extraction contains a water phase that causes cellular swelling. Therefore, the cell walls would become more permeable for the solvent (Guckert and White, 1988). Although the definite cell location of BHPs in general or that of individual BHPs (e.g. 35-amino BHPs) is not known for certain, such a cellular swelling effect of the Bligh \& Dyer extraction might particularly affect specific cell membranes rich in 35- amino BHPs. This, however, remains to be clarified and we can only state that Bligh \& Dyer extraction in particular improves the extraction efficiency for 35-amino-BHPs.

\subsection{Conclusions}

With respect to the major BHPs, our work has shown that single phase solvent extraction using microwave, ultrasound or Bligh \& Dyer extraction gave similar yields, with microwave and ultrasound revealing the closest similarity. For studies aimed in particular at BHPs with an amino group, Bligh \& Dyer extraction may, however, be preferred due to higher recovery of this group of compounds. The extraction method should therefore be taken into account when comparing BHP distributions from different studies.

\section{Acknowledgments}

We thank C. Conradt for laboratory assistance, and T. Licha and K. Nödler for help with LC-MS. We also thank O. Schmale for providing the sediment samples and D. Rush and an anonymous reviewer for constructive comments. The German Research 
Foundation (Deutsche Forschungsgemeinschaft, DFG) is acknowledged for financial support (Grants BL 971/1-3 and 971/3-1).

\section{References}

Berndmeyer, C., Thiel, V., Schmale, O., Blumenberg, M., 2013. Biomarkers for aerobic methanotrophy in the water column of the stratified Gotland Deep (Baltic Sea). Organic Geochemistry 55, 103-111.

Bligh, E.G., Dyer, W.J., 1959. A rapid method of total lipid extraction and purification. Canadian Journal of Biochemistry and Physiology 37, 911-917.

Blumenberg, M., Berndmeyer, C., Moros, M., Muschalla, M., Schmale, O., Thiel, V., 2013. Bacteriohopanepolyols record stratification, nitrogen fixation and other biogeochemical perturbations in Holocene sediments of the central Baltic Sea. Biogeosciences 10, 2725-2735.

Blumenberg, M., Seifert, R., Kasten, S., Bahlmann, E., Michaelis, W., 2009. Euphotic zone bacterioplankton sources major sedimentary bacteriohopanepolyols in the Holocene Black Sea. Geochimica et Cosmochimica Acta 73, 750-766.

Blumenberg, M., Seifert, R., Michaelis, W., 2007. Aerobic methanotrophy in the oxicanoxic transition zone of the Black Sea water column. Organic Geochemistry 38, 8491.

Blyth, A.J., Farrimond, P., Jones, M., 2006. An optimised method for the extraction and analysis of lipid biomarkers from stalagmites. Organic Geochemistry 37, 882890.

Carman, R., Rahm, L., 1997. Early diagenesis and chemical characteristics of interstitial water and sediments in the deep deposition bottoms of the Baltic proper. Journal of Sea Research 37, 25-47. 
Cooke, M.P., 2011. The Role of Bacteriohopanepolyols as Biomarkers for Soil Bacterial Communities and Soil derived Organic Matter. PhD Thesis, Newcastle University, UK. <http://hdl.handle.net/10443/1139>.

Cooke, M.P., Talbot, H.M., Farrimond, P., 2008. Bacterial populations recorded in bacteriohopanepolyol distributions in soils from Northern England. Organic Geochemistry 39, 1347-1358.

Cooke, M.P., van Dongen, B.E., Talbot, H.M., Semiletov, I., Shakhova, N., Guo, L., Gustafsson, 0., 2009. Bacteriohopanepolyol biomarker composition of organic matter exported to the Arctic Ocean by seven of the major Arctic rivers. Organic Geochemistry 40, 1151-1159.

Doğrul Selver, A., Talbot, H.M., Gustafsson, O., Boult, S., van Dongen, B.E., 2012. Soil organic matter transport along an sub-Arctic river-sea transect. Organic Geochemistry 51, 63-72.

Farrimond, P., Head, I.M., Innes, H.E., 2000. Environmental influence on the biohopanoid composition of recent sediments. Geochimica et Cosmochimica Acta 64, 2985-2992.

Guckert, J.B., White, D.C., 1988. Evaluation of a hexane/isopropanol lipid solvent system for analysis of bacterial phospholipids and application to chloroformsoluble Nuclepore (polycarbonate) membranes with retained bacteria. Journal of Microbiological Methods 8, 131-137.

Huguet, C., Martens-Habbena, W., Urakawa, H., Stahl, D.A., Ingalls, A.E., 2010. Comparison of extraction methods for quantitative analysis of core and intact polar glycerol dialkyl glycerol tetraethers (GDGTs) in environmental samples. Limnology and Oceanography: Methods 8, 127-145.

Iverson, S.J., Lang, S.L.C., Cooper, M.H., 2001. Comparison of the Bligh and Dyer and Folch methods for total lipid determination in a broad range of marine tissue. Lipids 36, 1283-1287. 
Jahnke, L.L., Summons, R.E., Hope, J.M., Des Marais, D.J., 1999. Carbon isotopic fractionation in lipids from methanotrophic bacteria II: the effects of physiology and environmental parameters on the biosynthesis and isotopic signatures of biomarkers. Geochimica et Cosmochimica Acta 63, 79-93.

Jansen, B., Nierop, K.G.J., Kotte, M.C., de Voogt, P., Verstraten, J.M., 2006. The applicability of accelerated solvent extraction (ASE) to extract lipid biomarkers from soils. Applied Geochemistry 21, 1006-1015.

Kharbush, J.J., Ugalde, J.A., Hogle, S.L., Allen, E.E., Aluwihare, L.I., 2013. Composite bacterial hopanoids and their microbial producers across oxygen gradients in the water column of the California Current. Applied and Environmental Microbiology, 79.

Lewis, T., Nichols, P.D., McMeekin, T.A., 2000. Evaluation of extraction methods for recovery of fatty acids from lipid-producing microheterotrophs. Journal of Microbiological Methods 43, 107-116.

Macnaughton, S.J., Jenkins, T.L., Wimpee, M.H., Cormier, M.R., White, D.C., 1997. Rapid extraction of lipid biomarkers from pure cultures and environmental samples using pressurized accelerated hot solvent extraction. Journal of Microbiological Methods 31, 19-27.

Pearson, A., Leavitt, W.D., Sáenz, J.P., Summons, R.E., Tam, M.C.M., Close, H.G., 2008. Diversity of hopanoids and squalene-hopene cyclases across a tropical land-sea gradient. Environmental Microbiology 11, 1208-1223.

Péres, V.F., Saffi, J., Melecchi, M.I.S., Abad, F.C., de Assis Jacques, R., Martinez, M.M., Oliveira, E.C., Caramão, E.B., 2006. Comparison of soxhlet, ultrasound-assisted and pressurized liquid extraction of terpenes, fatty acids and vitamin E from Piper gaudichaudianum Kunth. Journal of Chromatography A 1105, 115-118.

Rashby, S.E., Sessions, A.L., Summons, R.E., Newman, D.K., 2007. Biosynthesis of 2methylbacteriohopanepolyols by an anoxygenic phototroph. Proceedings of the National Academy of Sciences USA 104, 15099-15104. 
Renoux, J.M., Rohmer, M., 1985. Prokaryotic triterpenoids: New bacteriohopanetetrol cyclitol ethers from the methylotrophic bacterium Methylobacterium organophilum. European Journal of Biochemistry 151, 405-410.

Rethemeyer, J., Schubotz, F., Talbot, H.M., Cooke, M.P., Hinrichs, K.U., Mollenhauer, G., 2010. Distribution of polar membrane lipids in permafrost soils and sediments of a small high Arctic catchment. Organic Geochemistry 41, 1130- 1145.

Sáenz, J.P., Eglinton, T.I., Summons, R.E., 2011a. Abundance and structural diversity of bacteriohopanepolyols in suspended particulate matter along a river to ocean transect. Organic Geochemistry 42, 774-780.

Sáenz, J.P., Wakeham, S.G., Eglinton, T.I., Summons, R.E., 2011b. New constraints on the provenance of hopanoids in the marine geologic record: bacteriohopanepolyols in marine suboxic and anoxic environments. Organic Geochemistry 42, 1351-1362.

Sáenz, J.P., Waterbury, J.B., Eglinton, T.I., Summons, R.E., 2012. Hopanoids in marine cyanobacteria: probing their phylogenetic distribution and biological role. Geobiology 10, 311-319.

Schaeffer, P., Schmitt, G., Adam, P., Rohmer, M., 2008. Acid-catalyzed formation of 32,35-anhydrobacteriohopanetetrol from bacteriohopanetetrol. Organic Geochemistry 39, 1479-1482.

Schaeffer, P., Schmitt, G., Adam, P., Rohmer, M., 2010. Abiotic formation of 32,35anhydrobacteriohopanetetrol: a geomimetic approach. Organic Geochemistry 41, 1005-1008.

Schmidt, F., Hinrichs, K.U., Elvert, M., 2010. Sources, transport, and partitioning of organic matter at a highly dynamic continetal margin. Marine Chemistry 118, 37-55.

Sessions, A.L., Zhang, L., Welander, P.V., Doughty, D., Summons, R.E., Newman, D.K., 2013. Identification and quantification of polyfunctionalized hopanoids by high temperature gas chromatography-mass spectrometry. Organic Geochemistry 56, 120-130. 
Sinninghe Damste, J.S., Rijpstra, W.I.C., Schouten, S., Fuerst, J.A., Jetten, M.S.M., Strous, M., 2004. The occurrence of hopanoids in planctomycetes: implications for the sedimentary biomarker record. Organic Geochemistry 35, 561-566.

Summons, R.E., Jahnke, L.L., Roksandic, Z., 1994. Carbon isotopic fractionation in lipids from methanotrophic bacteria: relevance for interpretation of the geochemical record of biomarkers. Geochimica et Cosmochimica Acta 58, 2853-2863.

Talbot, H.M., Farrimond, P., 2007. Bacterial populations recorded in diverse sedimentary biohopanoid distributions. Organic Geochemistry 38, 1212-1225.

Talbot, H.M., Farrimond, P., Schaeffer, P., Pancost, R.D., 2005. Bacteriohopanepolyols in hydrothermal vent biogenic silicates. Organic Geochemistry 36, 663-672.

Talbot, H.M., Squier, A.H., Keely, B.J., Farrimond, P., 2003a. Atmospheric pressure chemical ionisation reversed-phase liquid chromatography/ion trap mass spectrometry of intact bacteriohopanepolyols. Rapid Communications in Mass Spectrometry 17, 728-737.

Talbot, H.M., Summons, R.E., Jahnke, L.L., Cockell, C.S., Rohmer, M., Farrimond, P., 2008. Cyanobacterial bacteriohopanepolyol signatures from cultures and natural environmental settings. Organic Geochemistry 39, 232-263.

Talbot, H.M., Summons, R.E., Jahnke, L.L., Farrimond, P., 2003b. Characteristic fragmentation of bacteriohopanepolyols during atmospheric pressure chemical ionisation liquid chromatography/ion trap mass spectrometry. Rapid Communications in Mass Spectrometry 17, 2788-2796.

Wakeham, S.G., Amann, R., Freeman, K.H., Hopmans, E.C., Jorgensen, B.B., Putnam, I.F., Schouten, S., Sinninghe Damste, J.S., Talbot, H.M., Woebken, D., 2007. Microbial ecology of the stratified water column of the Black Sea as revealed by a comprehensive biomarker study. Organic Geochemistry 38, 2070-2097. 
White, D.C., Ringelberg, D.B., 1998. Signature lipid biomarker analysis. In: Burlage, R.S., Atlas, R., Stahl, D., Geesey, G., Sayler, G. (Eds.), Techniques in Microbial Ecology. Oxford University Press, New York, pp. 255-272. 


\title{
Biomarkers in the stratified water column of the Landsort Deep (Baltic Sea)
}

\author{
Christine Berndmeyer, Volker Thiel, Oliver Schmale, Norbert Wasmund, and \\ Martin Blumenberg
}

Biogeosciences Discussions (2014) 11, 9853-9887.

DOI: 10.5194/bgd-11-9853-2014, Open Access

\subsection{Abstract}

The water column of the Landsort Deep, central Baltic Sea, is stratified into an oxic, suboxic and anoxic zone. This stratification controls the distributions of individual microbial communities and biogeochemical processes. In summer 2011, particulate organic matter was filtered from these zones using an in situ pump. Lipid biomarkers were extracted from the filters to establish water column profiles of individual hydrocarbons, alcohols, phospholipid fatty acids, and bacteriohopanepolyols (BHPs). As a reference, a cyanobacterial bloom sampled in summer 2012 in the central Baltic Sea Gotland Deep was analyzed for BHPs. The biomarker data from the surface layer of the oxic zone showed major inputs from different cyanobacteria and eukaryotes such as dinoflagellates and ciliates, while the underlying cold winter water layer was characterized by a low diversity and abundance of organisms, with copepods as a major group. The suboxic zone supported bacterivorous ciliates, type I aerobic methanotrophic bacteria, sulfate reducing bacteria, and, most likely, methanogenic archaea. In the anoxic zone, sulfate reducers and archaea were the dominating microorganisms as indicated by the presence of distinctive branched fatty acids, archaeol and PMI derivatives, respectively. Our study of in situ biomarkers in the Landsort Deep thus provided an integrated insight into the distribution of relevant players and the related biogeochemical processes in stratified water columns of marginal seas. 


\subsection{Introduction}

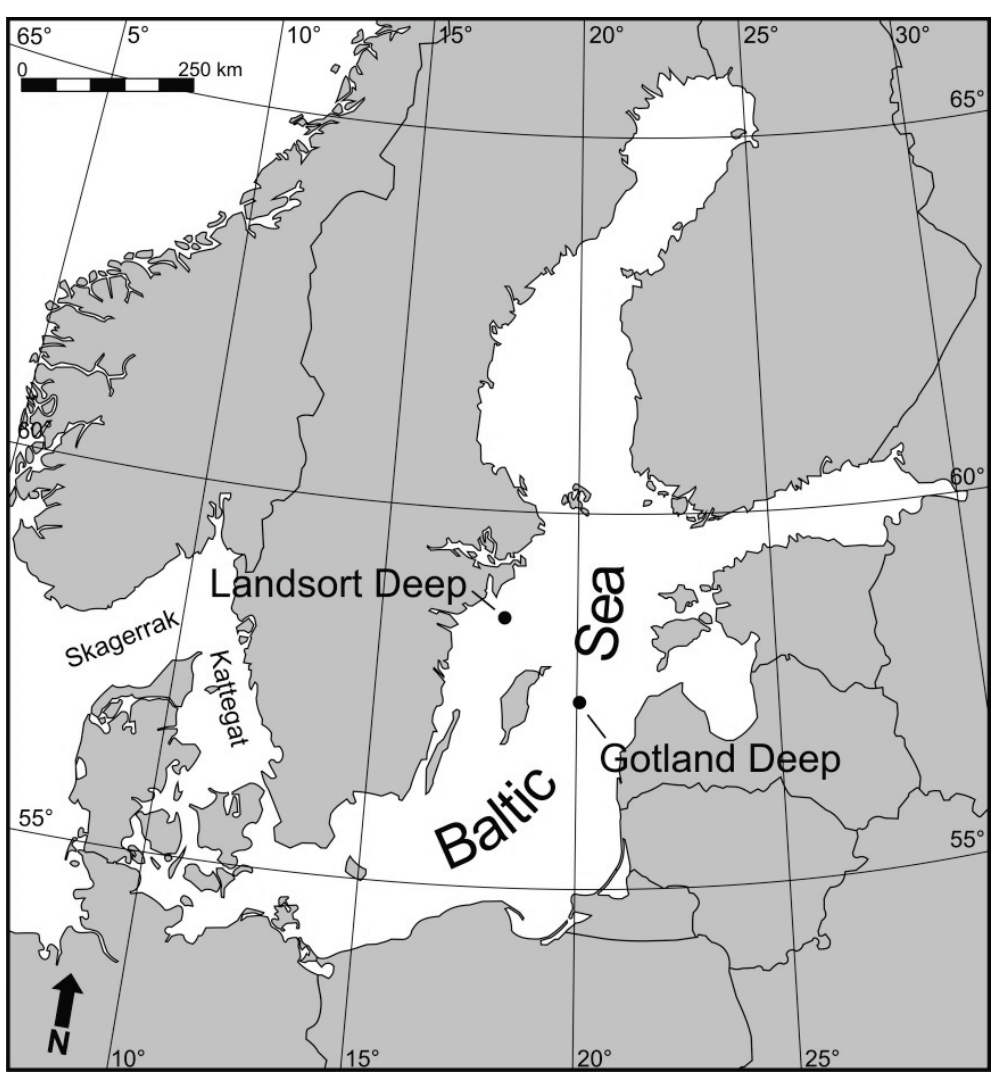

Fig. 1: Map showing the sampling locations in the central Baltic Sea.
The Baltic Sea is a brackish marine marginal Sea with a maximum depth of $459 \mathrm{~m}$ in the Landsort Deep (western central Baltic Sea; Matthäus and Schinke, 1999; Reissmann et al., 2009; Fig. 1). A positive freshwater budget and saltwater inflows from the North Sea through Skagerrak and Kattegat lead to a permanent halocline that stratifies the water column of the central Baltic Sea at about

$60 \mathrm{~m}$ water depth (Reissmann et al., 2009). Major saltwater inflows, as detected in 1993 and 2003, sporadically disturb the stratification in the eastern central Baltic Sea and oxygenate the suboxic zone and deep water. These inflows, however, rarely reach the western central Baltic Sea, and thus, even the strong inflow from 1993 had only minor effects on Landsort Deep, where stagnating conditions prevailed throughout (Bergström and Matthäus, 1996). The relatively stable stratification in the Landsort Deep provides environments for microbial life within the oxic, suboxic and anoxic zones.

Little is known, however, about the particulate organic matter (POM) sources and biomarker distributions in the Landsort Deep water column (and the Baltic Sea in general), as most studies focus on pollution related markers in particular organisms and sediments (e.g. Beliaeff and Burgeot, 2001; Lehtonen et al., 2006; Hanson et al., 2009). Recent work has given insight into the distributions of bacteriohopanepolyols (BHPs) and phospholipid fatty acids (PLFA) in the water column of the Gotland Deep (eastern central Baltic Sea), but these studies were 
focused on bacterial methanotrophy (Schmale et al., 2012; Berndmeyer et al., 2013; Jakobs et al., under review). In these investigations, as well as in our current study, in situ pumping was used for sampling. In situ pumping allows sampling of biomarkers in exactly the water depth where they are produced, thus providing information about the coupling of water column chemistry and microbial life. Several focused in situ biomarker water column studies exist (Schouten et al., 2001; Schubert et al., 2006; Blumenberg et al., 2007; Sáenz et al., 2011; Xie et al., 2014, and others). Comprehensive in situ biomarker reports exist from the Black Sea water column (Wakeham et al., 2007; 2012). These studies gave a wide-ranging overview of various biomarkers and their producers, and identified a close coupling of microorganisms to water layers. With respect to bacterial methane oxidation, the importance of the Baltic Sea suboxic zone for microbial processes was recently confirmed by Jakobs et al. (2013; under review). The authors also stated the theoretical possibility of sulfate-dependent methane oxidation in the anoxic zone, a process that still has to be proven in the central Baltic Sea water column. Because the eastern central Baltic Sea is regularly disturbed by lateral intrusions in intermediate water depths (Jakobs et al., 2013), we chose the more stable Landsort Deep in the western central Baltic Sea as a sampling site for this biomarker study. Here we report the depth profiles of individual lipids from Landsort Deep, providing further insight into the distribution of relevant biota and the connected biogeochemical processes in stratified water columns.

\subsection{Material and methods}

\subsubsection{Samples}

Samples were taken during cruise 06EZ/11/05 of R/V Elisabeth Mann Borghese in summer 2011. The Landsort Deep is located north of Gotland (58 $35.0^{\prime}$ N 18¹4.0’ E; Fig. 1). A Seabird sbe911+ CTD system and a turbidity sensor ECO FLNTU (WET Labs) were used for continuous water column profiling. Oxygen and hydrogen sulfide concentrations were measured with Winkler's method and colometrically, respectively (Grasshoff et al., 1983). Filter samples of 65 to $195 \mathrm{l}$ obtained from 10, 65, 70, 80, 90, 95 and $420 \mathrm{~m}$ water depth were taken with an in situ pump and particulate material was filtered onto precombusted glass microfiber filters $(\varnothing$ 
$30 \mathrm{~cm}$; $0.7 \mu \mathrm{m}$ pore size; Munktell \& Filtrak GmbH, Germany). Filters were freeze dried and kept frozen at $-20^{\circ} \mathrm{C}$ until analysis.

A cyanobacterial bloom was sampled in summer 2012 on cruise M87/4 of R/V Meteor at the Gotland Deep (57 $19.2^{\prime} \mathrm{N}, 20^{\circ} 03.0^{\prime} \mathrm{E}$; Fig. 1), east of Gotland. Water samples of $10 \mathrm{l}$ were taken at $1 \mathrm{~m}$ water depth and filtered with a $20 \mu \mathrm{m}$ net. The samples were centrifuged and the residue freeze dried. Samples were kept frozen at $-20^{\circ} \mathrm{C}$ until analysis.

\subsubsection{Bulk CNS analysis}

Three pieces $(\varnothing 1.2 \mathrm{~cm})$ from different zones of the filters were combusted together with $\mathrm{Vn}_{2} \mathrm{O}_{5}$ in a EuroVector EuroEA Elemental Analyzer. Particulate matter in the Baltic Sea was reported to be free of carbonate (Schneider et al., 2002), and thus, the filters were not acidified prior to analysis. $\mathrm{C}, \mathrm{N}$, and S contents were calculated by comparison with peak areas from standards. Standard deviations were $\pm 2 \%$ for C and $\pm 5 \%$ for $\mathrm{N}$ and $\mathrm{S}$.

\subsubsection{Lipid analysis}

$3 / 4$ of each filter was extracted ( $3 \times 20 \mathrm{~min}$ ) with dichloromethane (DCM)/methanol $(\mathrm{MeOH})(40 \mathrm{ml} ; 3: 1, \mathrm{v}: \mathrm{v})$ in a CEM Mars 5 microwave (Matthews, NC, USA) at $60^{\circ} \mathrm{C}$ and $800 \mathrm{~W}$. All extracts were combined.

The freeze dried residue of the cyanobacterial bloom was extracted ( 3 x $10 \mathrm{~min}$ ) with DCM/MeOH (10 ml; 3:1, v:v) and ultrasonication. All extracts were combined. An aliquot of each filter extract and the bloom extract was acetylated using $\mathrm{Ac}_{2} \mathrm{O}$ and pyridine $(1: 1, \mathrm{v}: \mathrm{v})$ for $1 \mathrm{~h}$ at $50{ }^{\circ} \mathrm{C}$ and then overnight at room temperature. The mixture was dried under vacuum and analyzed for BHPs using LC-MS.

Another aliquot of each filter extract was separated into a hydrocarbon (F1), an alcohol and ketone (F2) and a polar fraction (F3) using column chromatography. The column ( $\varnothing$ ca. $1 \mathrm{~cm}$ ) was filled with $7.5 \mathrm{~g}$ silica gel 60, samples were dried on ca. $500 \mathrm{mg}$ silica gel 60 and placed on the column. The fractions were eluted with $30 \mathrm{ml}$ n-hexane/DCM 8:2 (v:v, F1), $30 \mathrm{ml}$ DCM/EtOAC 9:1 (v:v, F2) and $100 \mathrm{ml}$ DCM/MeOH 1:1, (v:v) followed by additional $100 \mathrm{ml} \mathrm{MeOH} \mathrm{(F3).} \mathrm{F2} \mathrm{was} \mathrm{dried} \mathrm{and} \mathrm{derivatized}$ using a BSTFA/pyridine $3: 2(\mathrm{v}: \mathrm{v})$ mixture for $1 \mathrm{~h}$ at $40{ }^{\circ} \mathrm{C} .50 \%$ of the polar fraction 
F3 was further fractionated to obtain PLFA (F3.3) according to Sturt et al. (2004). Briefly, the column was filled with $2 \mathrm{~g}$ silica gel 60 and stored at $200^{\circ} \mathrm{C}$ until use. The F3 aliquot was dried on ca. $500 \mathrm{mg}$ silica gel 60 and placed on the column. After successive elution of the column with $15 \mathrm{ml}$ DCM and $15 \mathrm{ml}$ acetone, the PLFA fraction was eluted with $15 \mathrm{ml} \mathrm{MeOH} \mathrm{(F3.3).} \mathrm{F3.3} \mathrm{was} \mathrm{transesterified} \mathrm{using}$ trimethylchlorosilane (TMCS) in $\mathrm{MeOH}$ (1:9; v:v) for $1 \mathrm{~h}$ at $80{ }^{\circ} \mathrm{C}$. In the resulting fatty acid methyl ester (FAME) fractions, double bond positions in monounsaturated compounds were determined using dimethyldisulfide (DMDS; Carlson et al., 1989;Gatellier et al., 1993). The samples were dissolved in $200 \mu \mathrm{l}$ DMDS, $100 \mu \mathrm{l} n$ hexane, and $30 \mu \mathrm{I}_{2}$ solution ( $60 \mathrm{mg} \mathrm{I} 2$ in $1 \mathrm{ml} \mathrm{Et}_{2} \mathrm{O}$ ) and derivatized at $50{ }^{\circ} \mathrm{C}$ for $48 \mathrm{~h}$. Subsequently, $1 \mathrm{ml}$ of $n$-hexane and $200 \mu \mathrm{l}$ of $\mathrm{NaHSO}_{4}$ (5\% in water) were added and the $n$-hexane extract was pipetted off. The procedure was repeated $3 \mathrm{x}$, the $n$-hexane extracts were combined, dried on ca. $500 \mathrm{mg}$ silica gel 60 and put onto a small column (ca. $1 \mathrm{~g}$ silica gel 60). For cleaning, the $n$-hexane extract was eluted with ten dead volumes of DCM. F1, F2, F3.3 and the samples treated with DMDS were analyzed using GC-MS.

\subsubsection{Gas chromatography-mass spectrometry (GC-MS) and GC-combustion isotope ratio mass spectrometry (GC-C-IRMS)}

GC-MS was performed using a Varian CP-3800 chromatograph equipped with a Phenomenex Zebron ZB-5MS fused silica column (30 m x $0.32 \mathrm{~mm}$; film thickness $0.25 \mu \mathrm{m}$ ) coupled to a Varian 1200L mass spectrometer. Helium was used as carrier gas. The temperature program started at $80{ }^{\circ} \mathrm{C}(3 \mathrm{~min})$ and ramped to $310^{\circ} \mathrm{C}$ (held $25 \mathrm{~min}$ ) with $4{ }^{\circ} \mathrm{C} \mathrm{min}^{-1}$. Compounds were assigned comparing mass spectra and retention times to published data. Concentrations were determined by comparison with peak areas of internal standards.

Compound specific stable carbon isotope ratios of biomarkers in F2 and F3.3 were measured (2x) using a Thermo Trace GC gas chromatograph coupled to a Thermo Delta Plus isotope ratio mass spectrometer. The GC was operated under the same conditions and with the same column as for GC-MS. The combustion reactor contained $\mathrm{CuO}, \mathrm{Ni}$ and $\mathrm{Pt}$ and was operated at $940{ }^{\circ} \mathrm{C}$. Isotopic compositions are reported in standard delta notation relative to the Vienna PeeDee Belemnite (V- 
PDB) and were calculated by comparison with an isotopically known $\mathrm{CO}_{2}$ reference gas. GC-C-IRMS precision and linearity was checked daily using an external $n$-alkane isotopic standard (provided by A. Schimmelmann, Indiana University).

\subsubsection{Liquid chromatography-mass spectrometry (LC-MS)}

LC-MS was performed using a Varian Prostar Dynamax HPLC system fitted with a Merck Lichrocart (Lichrosphere 100; reversed phase (RP) $\mathrm{C}_{18 \mathrm{e}}$ column [250 x $4 \mathrm{~mm}]$ ) and a Merck Lichrosphere pre-column of the same material coupled to a Varian 1200L triple quadrupole mass spectrometer (both Varian). Used solvents were $\mathrm{MeOH} /$ water 9:1 (v:v; solvent A) and $\mathrm{MeOH} /$ propan-2-ol 1:1 (v:v; solvent B), and all solvents were Fisher Scientific HPLC grade. The solvent gradient profile was $100 \% \mathrm{~A}(0-1 \mathrm{~min})$ to $100 \% \mathrm{~B}$ at $35 \mathrm{~min}$, then isocratic to $60 \mathrm{~min}$. The MS was equipped with an atmospheric pressure chemical ionization (APCI) source operated in positive ion mode (capillary temperature $150{ }^{\circ} \mathrm{C}$, vaporizer temperature $400{ }^{\circ} \mathrm{C}$, corona discharge current $8 \mu \mathrm{A}$, nebulizing gas flow 70 psi, auxiliary gas 17 psi). In SIM (single ion monitoring) mode, ions obtained from acetylated BHP peaks in the samples were compared to authentic BHP standards with known concentration (acetylated BHP and aminotriol) to determine BHP concentrations (external calibration). Amino BHPs had a 7x higher response factor than non-amino BHPs and concentrations in the samples were corrected accordingly. Comparisons with elution times of previously identified compounds further aided in BHP assignment. The quantification error is estimated to be $\pm 20 \%$.

\subsection{Results}

\subsubsection{Physicochemical parameters of the water column}

In summer 2011, the Landsort Deep showed a strong vertical stratification (Fig. 2). The oxic zone consisted of the uppermost $80 \mathrm{~m}$ and was divided by a strong thermocline into a warm surface layer $(\sim 0-10 \mathrm{~m})$ and a cold winter water layer ( 10-70 m). The halocline was located between $60 \mathrm{~m}$ and $80 \mathrm{~m} . \mathrm{O}_{2}$ concentrations rapidly decreased from $>8 \mathrm{ml} \mathrm{l}^{-1}$ at $\sim 50 \mathrm{~m}$ to $<0.2 \mathrm{ml} \mathrm{l}^{-1}$ at $\sim 80 \mathrm{~m}$, defining the upper boundary of the suboxic zone (Tyson and Pearson, 1991). $\mathrm{H}_{2} \mathrm{~S}$ was first detected at $83 \mathrm{~m}$. Because $\mathrm{O}_{2}$ concentrations could methodically only be measured in the complete absence of $\mathrm{H}_{2} \mathrm{~S}$, oxygen could not be traced below this depth. Therefore, 


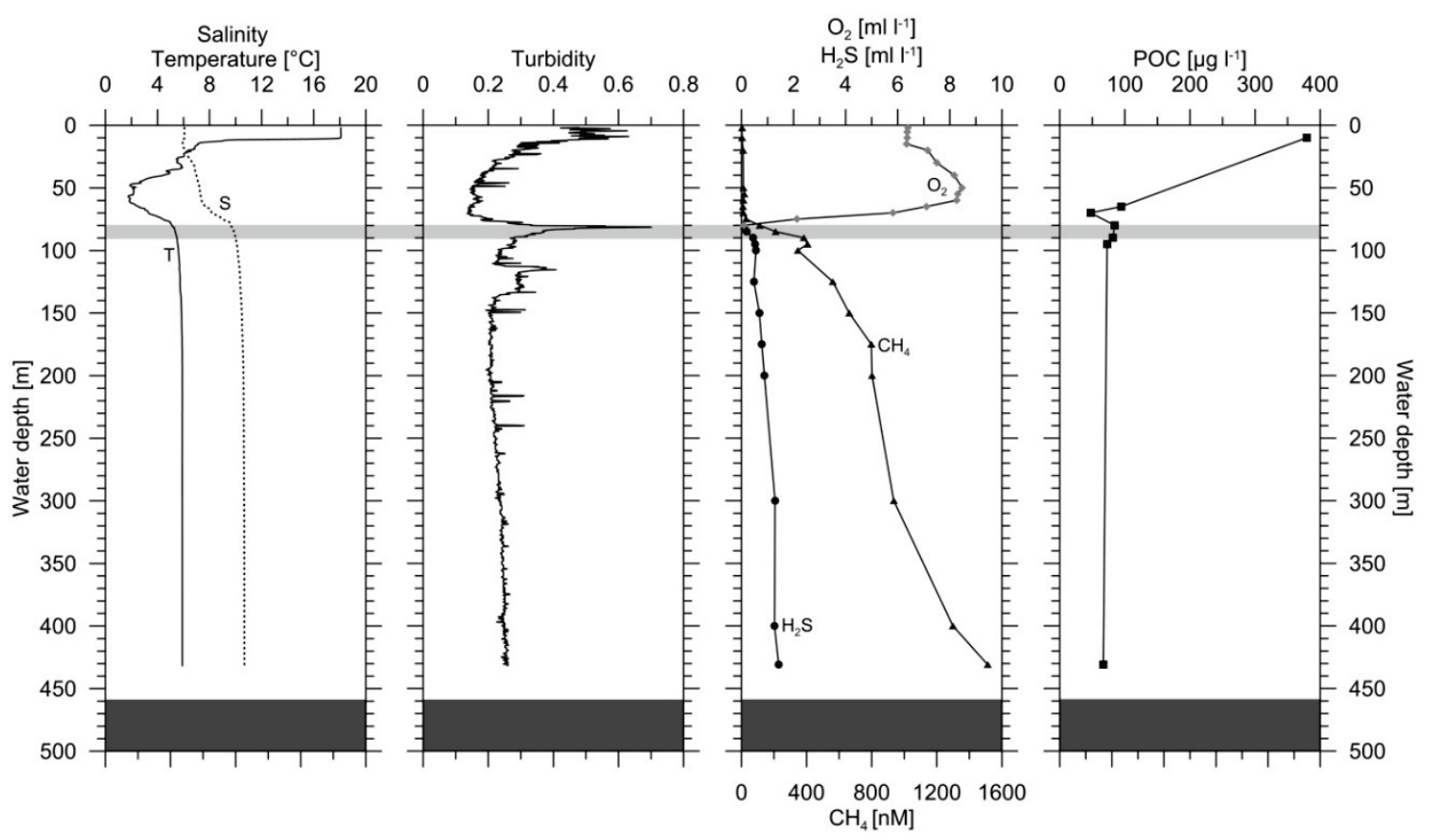

Fig. 2: Physico-chemical characteristics of the Landsort Deep water column in summer 2011. The suboxic zone is shaded light grey. Temperature and methane data partially taken from Jakobs et al. (under review).

the lower boundary of the suboxic zone was defined to be at $90 \mathrm{~m}$, where $\mathrm{H}_{2} \mathrm{~S}$ concentrations were sharply increasing. The suboxic zone also showed a sharp peak in turbidity that is possibly caused by precipitation of Fe and Mn oxides (Dellwig et al., 2010) or zero-valent sulfur (Kamyshny Jr. et al., 2013) and can be used as an indicator for the $\mathrm{O}_{2}-\mathrm{H}_{2} \mathrm{~S}$ transition (Kamyshny Jr. et al., 2013). The anoxic zone extends from $90 \mathrm{~m}$ to the bottom and is characterized by the complete absence of $\mathrm{O}_{2}$ and high concentrations of $\mathrm{H}_{2} \mathrm{~S}$ and $\mathrm{CH}_{4}$.

$\mathrm{CH}_{4}$ was highest in the deep anoxic zone, decreased strongly towards the suboxic zone but was still present in minor concentrations in the oxic zone. A small $\mathrm{CH}_{4}$ peak was detected at the suboxic-anoxic interface (Fig. 2). Particulate organic carbon (POC) was highest at $10 \mathrm{~m}\left(380 \mu \mathrm{g} \mathrm{l}^{-1}\right)$, decreased to a minimum in the cold winter water layer $\left(48 \mu \mathrm{g} \mathrm{l}^{-1}\right)$ and showed almost constant values of $\sim 70 \mu \mathrm{g} \mathrm{l}^{-1}$ in the suboxic and anoxic zones.

Generally, we follow the zonation of the Landsort Deep water column as used in Jakobs et al. (under review). We used the onset of $\mathrm{H}_{2} \mathrm{~S}$ as the top of the anoxic zone, however, as this is better supported by our biomarker data (see below). 

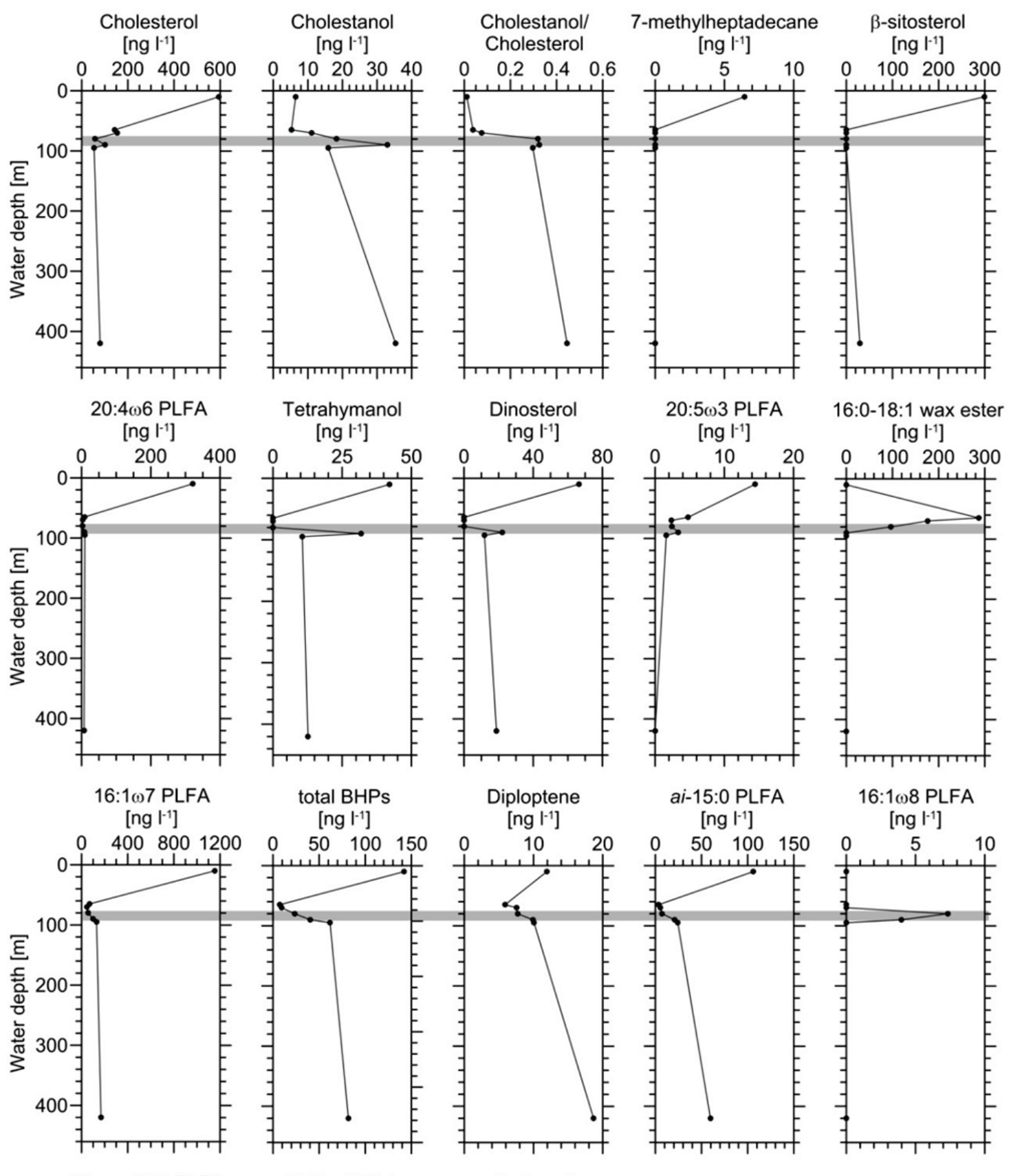

$[$ [ng |'-1]
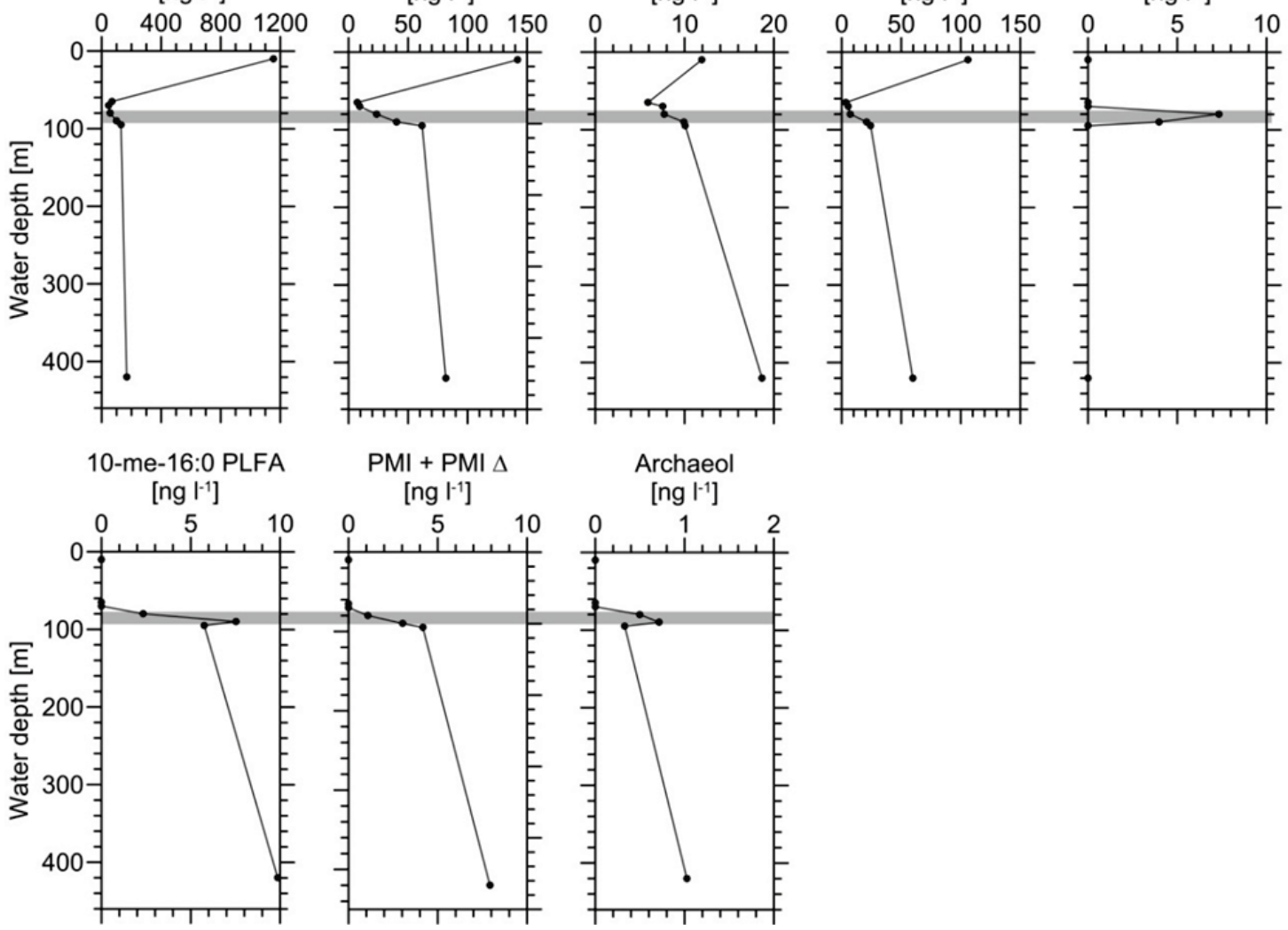

Fig. 3: Vertical distribution of biomarkers in the Landsort Deep water column. The suboxic zone is shaded grey. 


\subsubsection{Lipid analysis}

To obtain an overview about the sources and distributions of biomarkers in the water column, 17 major compounds were selected, specifying inputs from prokaryotes and eukaryotes (with phototrophic, chemotrophic and/or heterotrophic metabolisms). The concentrations of these compounds are shown in Fig. 3 and were distinguished into four major groups according to their profiles in the water column. Compound-specific $\delta^{13} \mathrm{C}$ values are given in Table 1 . Additionally, the $n$-alkane and $n$-alkene distributions in the sea surface layer (Fig. 4), the distribution of individual BHPs (Fig. 5a) and BHPs from bloom cyanobacteria were taken into account (Fig. $5 b)$.

\subsubsection{Group 1: surface maximum}

\begin{tabular}{|c|c|c|c|}
\hline Compound & $\begin{array}{l}\delta^{13} \mathrm{C}[\% \\
\text { oxic } \\
\text { zone } \\
\end{array}$ & $\begin{array}{l}\text { ] suboxic } \\
\text { zone }\end{array}$ & $\begin{array}{l}\text { anoxic } \\
\text { zone }\end{array}$ \\
\hline \multicolumn{4}{|l|}{ Group 1} \\
\hline $\begin{array}{l}\text { cholesterol } \\
\text { 7-me-17:0 alkane }\end{array}$ & $\begin{array}{r}-26.8 \\
\text { n.d. }\end{array}$ & $\begin{array}{r}-28.9 \\
\text { n.d. }\end{array}$ & $\begin{array}{r}-31.7 \\
\text { n.d. }\end{array}$ \\
\hline$\beta$-sitosterol & -29.9 & n.d. & -30.1 \\
\hline 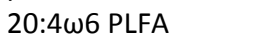 & -30.1 & -31.7 & -31.6 \\
\hline \multicolumn{4}{|l|}{ Group 2} \\
\hline tetrahymanol & -28.7 & -27.9 & -25.9 \\
\hline dinosterol & -29.9 & -30.9 & -32.0 \\
\hline \multicolumn{4}{|l|}{ Group 3} \\
\hline $\begin{array}{l}\text { 16:1 } 1 \omega 7 \text { PLFA } \\
\text { diploptene }\end{array}$ & $\begin{array}{r}-30.6 \\
\text { n.d. }\end{array}$ & $\begin{array}{r}-28.0 \\
\text { n.d. }\end{array}$ & $\begin{array}{r}-28.3 \\
\text { n.d. }\end{array}$ \\
\hline ai-15:0 PLFA & -29.3 & -32.5 & -34.2 \\
\hline \multicolumn{4}{|l|}{ Group 4} \\
\hline 10-me-16:0 PLFA & n.d. & -32.5 & -35.4 \\
\hline PMI +PMI $\Delta$ & n.d. & n.d. & n.d. \\
\hline archaeol & n.d. & n.d. & n.d. \\
\hline \multicolumn{4}{|l|}{ Others } \\
\hline cholestanol & -27.8 & -28.9 & -30.1 \\
\hline 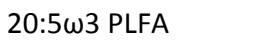 & -29.2 & n.d. & n.d. \\
\hline 16:0-18:1 wax ester & -28.1 & -28.2 & n.d. \\
\hline 16:1w8 PLFA & n.d. & -45.4 & n.d. \\
\hline
\end{tabular}

Tab. 1: $\delta^{13} \mathrm{C}$ values of the major compounds. The compounds were grouped according to their profile in the water column. N.d. = not detectable.

The first group is defined by a strong maximum in the surface layer. It contains cholest-5-en-3 $\beta$-ol (cholesterol), 7-methylheptadecane, 24-ethylcholest-5-en-3 $\beta$-ol

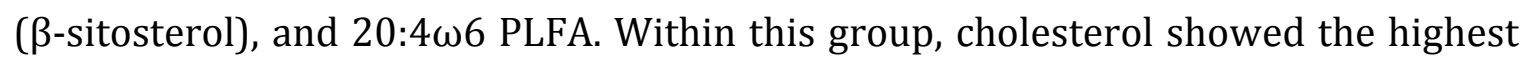
concentrations (594 $\mathrm{ng} \mathrm{l}^{-1}$ ), and 7-methylheptadecane the lowest (6 $\mathrm{ng} \mathrm{l}^{-1}$, Fig. 3). Apart from their maxima in the surface layer, the trend of these biomarkers differed

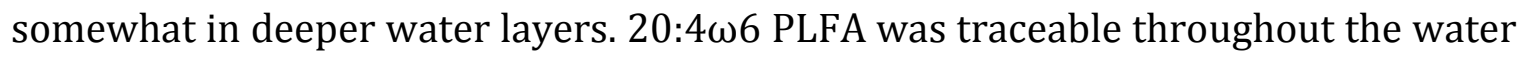
column, whereas 7-methylheptadecane exclusively occurred in the surface layer. $\beta$-sitosterol occurred in the surface and the bottom layer. Unlike the other compounds, cholesterol did not show a straight decrease with depth, rather are there minor peaks right above and at the bottom of the suboxic zone, respectively. These variations were small, however, and were not considered for grouping the compounds. $\delta^{13} \mathrm{C}$ values of all compounds were between -32 and $-26 \%$ (Table 1 ). 


\subsubsection{Group 2: surface and lower suboxic zone maxima}

This group contains only two compounds, $4 \alpha, 23,24$-trimethyl-5 $\alpha$-cholest-22E-en$3 \beta$-ol (dinosterol) and gammacer-3 $\beta$-ol (tetrahymanol). Both had their maximum concentration in the surface water (dinosterol: $66 \mathrm{ng} \mathrm{l}^{-1}$; tetrahymanol: $42 \mathrm{ng} \mathrm{l}^{-1}$ ) and were not detectable in the layers below, until a sharp second maximum occurred at the bottom of the suboxic zone. Concentrations decreased again below the suboxic zone and remained constantly low in the bottom water. Tetrahymanol was isotopically heavier in the oxic than in the anoxic zone $\left(\delta^{13} \mathrm{C}:-28.1 \mathrm{vs},-25.9 \%\right)$, whereas the opposite was observed for dinosterol ( $\left.\delta^{13} \mathrm{C}:-29.9 v s .-32.0 \% 0\right)$.

\subsubsection{Group 3: surface maximum, continuous increase in suboxic zone}

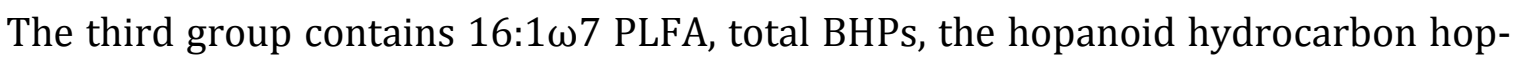
22(29)-ene (diploptene), and ai-15:0 PLFA. All these compounds were abundant in

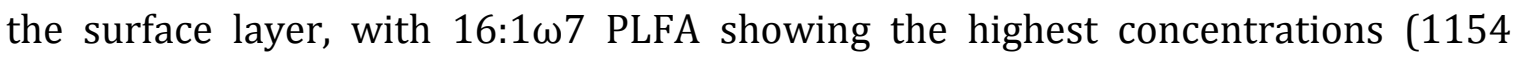
$\left.\mathrm{ng} \mathrm{l}^{-1}\right)$ and diploptene the lowest $\left(12 \mathrm{ng} \mathrm{l}^{-1}\right)$. A further feature is the continuous increase that extends throughout the suboxic zone and the anoxic zone. ai-15:0 PLFA shows a slight isotopic depletion in the anoxic zone $(-34.2 \%)$ whereas the other compounds of this group showed consistently higher $\delta^{13} \mathrm{C}$ values of about -28 to $-30 \%$.

\subsubsection{Group 4: Absent in the oxic zone, bottom layer maximum}

10-me-16:0 PLFA, the irregular $\mathrm{C}_{25}$ isoprenoid 2,6,10,15,19-pentamethylicosane (PMI), three unsaturated derivatives thereof (PMI $\Delta$ ), and 2,3-di- 0 -isopranyl sn-glycerol diether (archaeol) showed profiles defined in group four. These compounds were all absent in the oxic zone and only occurred in the suboxic zone and below. In all cases, maxima were detected in the anoxic zone, with highest amounts observed for 10-me-16:0 PLFA (10 $\left.\mathrm{ng} \mathrm{l}^{-1}\right)$ followed by PMI and PMI $\Delta$ (8 $\mathrm{ng} \mathrm{l}^{-1}$ ) and archaeol (1 $\mathrm{ng} \mathrm{l}^{-1}$ ). 10-me-16:0 PLFA shows a slight ${ }^{13} \mathrm{C}$ depletion in the anoxic zone (-35.4\%o). Concentrations of archaeol, PMI, and PMI $\Delta$ were too low to determine $\delta^{13} \mathrm{C}$. 


\subsubsection{Others}

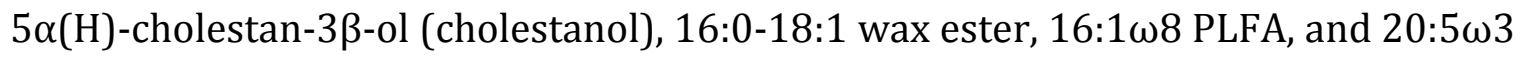
PLFA showed individual profiles not related to any of the groups defined above. Cholestanol shows lowest values within the oxic zone, although concentrations start to increase in the cold winter water layer. Maxima occur at the suboxic-anoxic interface (33 $\mathrm{ng} \mathrm{l}^{-1}$ ) and in the deep anoxic zone (35 $\mathrm{ng} \mathrm{l}^{-1}$ ). The wax ester shows maximum concentrations (286 $\left.\mathrm{ng} \mathrm{l}^{-1}\right)$ in the cold winter water layer, and a decrease through the suboxic zone. It was absent in the surface layer and in the anoxic zone. 20:5 $\omega 3$ PLFA has maximum concentrations in the surface layer (15 $\left.\mathrm{ng} \mathrm{l}^{-1}\right)$, remains at relatively high concentrations in the cold winter water layer $\left(6 \mathrm{ng} \mathrm{l}^{-1}\right)$ and shows a

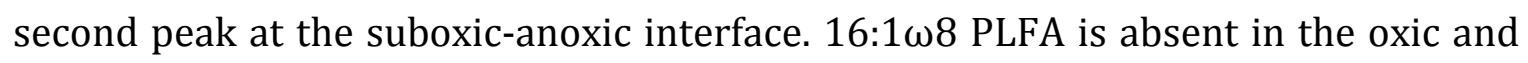
anoxic layers. It only occurs in the suboxic zone with a maximum concentration at its top $\left(7 \mathrm{ng} \mathrm{l}^{-1}\right)$. Of all compounds measured, it shows the lowest $\delta^{13} \mathrm{C}(-45.4 \%)$.

\subsection{8 n-alkanes and n-alkenes in the sea surface layer}

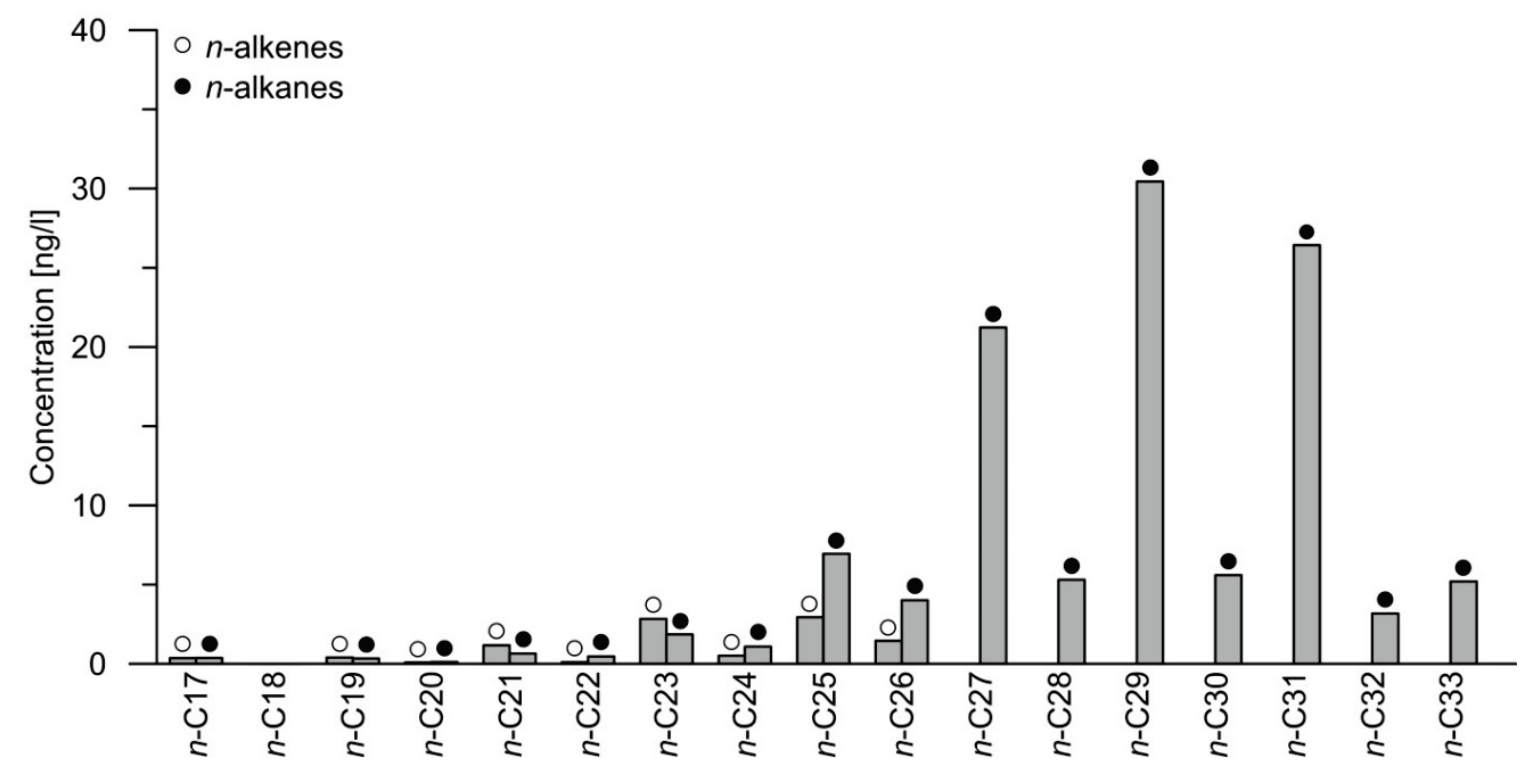

Fig. 4: Concentrations of $n$-alkanes and $n$-alkenes in the Landsort Deep surface layer (oxic zone, $10 \mathrm{~m}$ water depth).

The concentrations of $n$-alkanes and $n$-alkenes in the surface sample $(10 \mathrm{~m}$ water depth) are given in Fig. 4. The longest $n$-alkane chain was $n-C_{33}$, and odd carbon numbers dominated over even. Highest concentrations were found for $n-C_{27}$ (21 ng l-1), $n-\mathrm{C}_{29}\left(30 \mathrm{ng} \mathrm{l}^{-1}\right)$, and $n-\mathrm{C}_{31}\left(26 \mathrm{ng} \mathrm{l}^{-1}\right)$. The longest $n$-alkene chain was $n$ - 
$\mathrm{C}_{26: 1}$, highest $n$-alkene concentrations were measured for $n-\mathrm{C}_{23: 1}\left(3 \mathrm{ng} \mathrm{l}^{-1}\right)$ and $n-\mathrm{C}_{25: 1}$ $\left(3 \mathrm{ng} \mathrm{l}^{-1}\right)$.

\subsubsection{Individual BHPs}

In the Landsort Deep, seven individual BHPs were identified (Fig. 5a). In all samples bacteriohopane-32,33,34,35-tetrol (BHT) accounted for the greatest portion of the total BHPs (88-94\%). An as yet uncharacterized BHT isomer, BHT II, was present only below $70 \mathrm{~m}$ and showed its highest relative abundance $(\sim 2 \%)$ between 70 and $90 \mathrm{~m}$. BHT cyclitol ether, BHT glucosamine, and 35-aminobacteriohopane-32,33,34triol (aminotriol) were present throughout the water column. BHT cyclitol ether and BHT glucosamine were most abundant in the oxic zone (ca. 1-4\%), but showed only minor abundances $(<1 \%)$ below. Aminotriol was elevated at 65 and $420 \mathrm{~m}(\sim 7$ and $\sim 5 \%$, respectively). 35-aminobacteriohopane-31,32,33,34-tetrol (aminotetrol) occurred throughout the suboxic and anoxic zones, whereas 35-aminobacteriohopane-30,31,32,33,34-pentol (aminopentol) was observed only at $90 \mathrm{~m}$ and below. Both, aminotetrol and aminopentol showed minor relative abundances of $\sim 2 \%$ and $<1 \%$ of the total BHPs, respectively (Jakobs et al., under review).

At the Gotland Deep, a cyanobacterial bloom occurred, which consisted mainly of Aphanizonemon, to a smaller degree of Anabaena and Nodularia and was accompanied by dinoflagellates. The phytoplankton species and biomass were determined by the microscopical method according to the manual

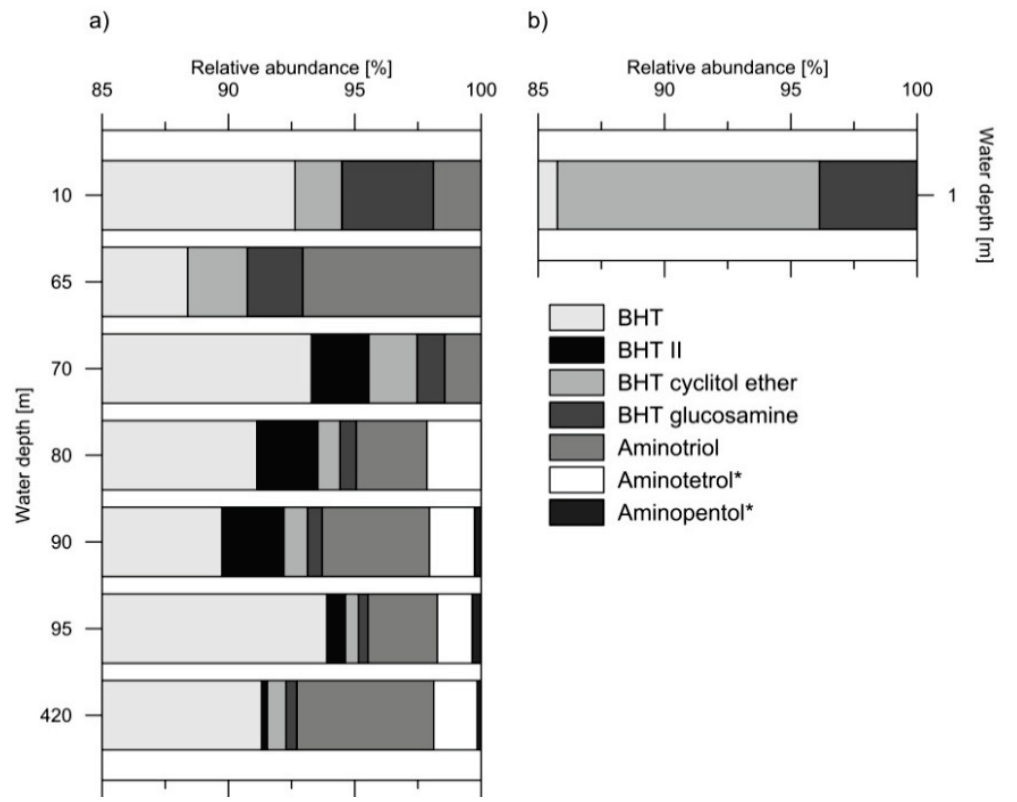

Fig. 5: Relative abundances of individual BHPs (as percent of the total) of a) the Landsort Deep water column and b) the Gotland Deep cyanobacterial bloom. Note that [\%]-axes start at $85 \%$. * = data taken from Jakobs et al. (under review). 
of HELCOM (2012). Three BHPs were observed in the bloom POM (Fig. 5b). Among these compounds, the most abundant was BHT ( $~ 86 \%)$, followed by BHT cyclitol ether $(\sim 10 \%)$, and BHT glucosamine $(\sim 4 \%)$.

\subsection{Discussion}

In the following, we discuss several aspects of the biomarker profiles with respect to their significance as tracers for the relevant biota and biogeochemical processes in stratified water columns.

\subsubsection{Water column redox zones as reflected by cholestanol/cholesterol ratios}

Different redox states of the Landsort Deep water column and the associated microbial processes are reflected by the profiles of cholesterol and its diagenetic product, cholestanol (Fig. 3). Cholesterol is produced by various eukaryotes such as plankton and higher plants (Parrish et al., 2000) and abundant in water columns and sediments In sediments as well as in stratified water columns, stanols are produced from sterols by anaerobic bacterial hydrogenation (Gaskell and Eglinton, 1975; Wakeham, 1989) and by the abiotic reduction of double bonds by reduced inorganic species such as $\mathrm{H}_{2} \mathrm{~S}$ (Hebting et al., 2006; Wakeham et al., 2007). Therefore, cholestanol/cholesterol ratios typically increase under more reducing conditions. In the Black Sea, low ratios of $\sim 0.1$ were associated with oxygenated surface waters (Wakeham et al., 2007). The suboxic zone showed ratios between 0.1 and 1 whereas the anoxic zone revealed values $>1$ (Wakeham et al., 2007). In the Landsort Deep, the cholestanol/cholesterol ratios showed a slight increase with depth from the surface towards the suboxic zone, but always remained $<0.1$. Below, the values increased to $\sim 0.3$ in the suboxic zone, and further to a maximum of 0.45 in the anoxic zone. Whereas the ratios in the Landsort Deep are considerably lower than in the Black Sea, the depth trend still clearly mirrors the changes from oxic to suboxic, and further to anoxic conditions. It is also interesting to note that total cholesterol and cholestanol concentrations in the Landsort Deep were ten- and fourfold higher, respectively, as in the Black Sea (Wakeham et al., 2007). 


\subsubsection{Phototrophic primary production}

As expected, in situ biomarkers for phototrophic organisms showed a clear preference for the surface layer. Among these compounds, 7-methylheptadecane is a characteristic marker for cyanobacteria (Shiea et al., 1990; Köster et al., 1999). Its most likely source are members of the subclass Nostocophyceae that were often reported to produce isomeric mid-chain branched alkanes, including 7-methylheptadecane (Shiea et al., 1990; Hajdu et al., 2007; Liu et al., 2013). Nostocophyceae are key members of the photoautotrophic community in the Baltic Sea. Particularly the filamentous genera Nodularia and Aphanizonemon (see 3.2.7), and the picocyanobacterium Synechococcus play a major role in blooms during summer time (Stal et al., 2003; Labrenz et al., 2007). The importance of cyanobacteria in the surface layer of the Landsort Deep is further reflected by the presence of $\mathrm{C}_{21: 1}, \mathrm{C}_{23: 1}$ and $\mathrm{C}_{25: 1} n$-alkenes (Fig. 4). These compounds have been reported from Anacystis (Gelpi et al., 1970) and Oscillatoria (Matsumoto et al., 1990). Oscillatoria vaucher is also known to occur in the Baltic Sea, but is of only minor abundance (Kononen et al., 1996; Vahtera et al., 2007).

20:4 $\omega 6$ PLFA is a biomarker traditionally assigned to eukaryotic phytoplankton (Nanton and Castell, 1999; Lang et al., 2011) and organisms grazing thereon, such as protozoa (Findlay and Dobbs, 1993; Pinkart et al., 2002; Risse-Buhl et al., 2011). High concentrations of 20:4 66 PLFA, as observed in the surface layer of the oxic zone, are in good agreement with such an authochthonous plankton-based source.

Long-chain $n$-alkanes with a strong predominance of the odd-numbered $n$ - $C_{25}$ to $n$ $\mathrm{C}_{33}$ homologues (Eglinton and Hamilton, 1967; Bi et al., 2005) and $\beta$-sitosterol (Volkman, 1986) are typical components of higher plant lipids. The occurrence and distributions of these compounds reflect a significant contribution from terrestrial higher plants and thus, continental runoff and/or aeolian input of terrigenous OM into the Landsort Deep.

\subsubsection{Phototrophic vs. heterotrophic dinoflagellates, and ciliates}

The distribution of dinoflagellates and ciliates in the water column is reflected by two specific biomarkers, dinosterol and tetrahymanol (see 3.2.2, Fig. 3). Dinosterol is mainly produced by dinoflagellates (Boon et al., 1979), although it was also reported in minor abundance from a diatom (Navicula sp., Volkman et al., 1993). The 
dinosterol concentrations in the Landsort Deep showed a bimodal distribution. The strong peak in the surface layer of the oxic zone most likely represents phototrophic dinoflagellates. Plausible candidates are Peridiniella catenata and Scrippsiella hangoei, both of which are involved in the spring phytoplankton blooms in the central Baltic Sea (Wasmund et al., 1998; Höglander et al., 2004). The latter species was previously reported to produce dinosterol (Leblond et al., 2007). However, $P$. catenata as well as $S$. hangoei are virtually absent below $50 \mathrm{~m}$ water depth (Höglander et al., 2004) and can thus not account for the second peak of dinosterol at the suboxic-anoxic transition zone. A likely source of dinosterol at this water depth are heterotrophic dinoflagellates that are abundant in the suboxic zones of the central Baltic Sea (Anderson et al., 2012). Due to their enhanced productivity, these environments provide good conditions to sustain communities of eukaryotic grazers (Detmer et al., 1993). A possible candidate, Gymnodinium beii, was described from the suboxic zones of the central Baltic Sea (Stock et al., 2009). Indeed, several Gymnodinium species are known to be heterotrophs (Strom and Morello, 1998) and some have been reported to produce dinosterol (Mansour et al., 1999).

A similar concentration distribution as for dinosterol was observed for tetrahymanol. Tetrahymanol is produced by ciliates as a substitute for cholesterol when grazing on prokaryotes instead of eukaryotes such as algae (Conner et al., 1968; Boschker and Middelburg, 2002). High concentrations of tetrahymanol were also described for the suboxic zone of the Black Sea (Wakeham et al., 2007), where ciliates were assumed to feed on chemoautotrophic bacteria. This is also a feasible scenario for the Baltic Sea where the ciliate genera Metopus, Strombidium, Metacystis, Mesodinium, and Coleps are abundant in the suboxic zone and at the suboxic-anoxic interface (Detmer et al., 1993; Anderson et al., 2012). Unidentified ciliates also occurred in the anoxic waters of the Landsort Deep (Anderson et al., 2012). We therefore assume ciliates living under suboxic to anoxic conditions to be the source of tetrahymanol in the suboxic zone and below.

In the Black Sea, tetrahymanol was absent in the surface waters (Wakeham et al., 2007) whereas the Landsort Deep showed the highest concentration at $10 \mathrm{~m}$ depth (Fig. 3). The occurrence of tetrahymanol at this depth appears paradox, as cholesterol is also abundant in the surface waters and thus, the ciliates could incorporate it, e.g. through grazing on eukaryote derived OM. On the other hand, 
some ciliates seem to prefer prokaryotes as a prey. Sinking agglomerates of cyanoand other bacteria are known to be covered by feeding ciliates (Gast and Gocke, 1988). Such a selective diet would plausibly explain the abundance of tetrahymanol in the shallow waters of the Landsort Deep.

$\delta^{13} \mathrm{C}$ values of tetrahymanol revealed an opposite trend as compared to dinosterol. While dinosterol became isotopically lighter with depth (-29.9 to $-32.0 \%)$, tetrahymanol became heavier (-28.7 to $-25.9 \%$ ) and showed its highest $\delta^{13} \mathrm{C}$ values in the anoxic zone. Although ciliates and dinoflagellates are both grazers at the suboxic-anoxic interface, they seem to occupy different ecological niches and feed on different bacterial sources.

\subsubsection{Heterotrophs in the cold winter water layer}

The only biomarkers with enhanced concentrations in the cold winter water layer are wax esters (e.g. 16:0-18:1 wax ester, Fig. 3) and 20:5 33 PLFA. Known producers of wax esters and 20:5 33 PLFA are copepods (Lee et al., 1971; Sargent et al., 1977; Kattner and Krause, 1989; Nanton and Castell, 1999; Falk-Petersen et al., 2002). These organisms synthesize wax esters with total chain lengths between 28 and 44 carbon atoms (Lee et al., 1971; Kattner and Krause, 1989; Falk-Petersen et al., 2002) of which several were present in the Landsort Deep (data not shown in Fig. 3), following the distribution of the most prominent 16:0-18:1. Particularly copepods rich in wax esters prefer deep water or near-surface cold water (Sargent et al., 1977), which is in full agreement with the high amounts of these compounds in the cold winter water layer. Copepods are abundant and diverse in the Baltic Sea, with major species being Pseudocalanus elongatus, Temora longicornis, and Acartia spp. (Möllmann et al., 2000; Möllmann and Köster, 2002). Like the wax esters, the 20:5 33 FA shows high concentrations in the cold winter water layer, but it is also abundant in the surface and at the suboxic-anoxic interface (Fig. 3), suggesting multiple biological origins for this compound. Dinoflagellates are known producers of 20:5 3 PLFA (Parrish et al., 1994; Volkman et al., 1998) and may be an alternative source in the surface layer and at the suboxic-anoxic interface, which is supported by a good correlation with dinosterol at these depths.

Unlike the abovementioned compounds, all other selected biomarkers show particularly low concentrations in the cold winter water layer. This is also true for 


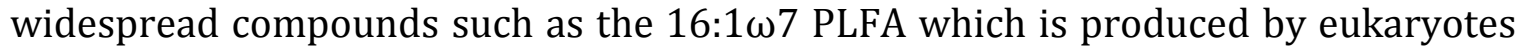
(Pugh, 1971; Shamsudin, 1992) as well as prokaryotes (Parkes and Taylor, 1983; Vestal and White, 1989). While a mixed origin of 16:1 107 PLFA has to be assumed for the oxic zone, a bacterial source is more probable in the suboxic zone and in the anoxic zone. Regardless of the biological source, a very low amount of this ubiquitous FA (Fig. 3) indicates that the cold winter water layer of the Landsort Deep does not support abundant planktonic life. Based on microscopy, similar observations have been made for the cold winter water layers of the Gotland, Bornholm and Danzig Basins (Gast and Gocke, 1988, and citations therein).

\subsubsection{BHPs as indicators for aerobic and anaerobic metabolisms}

Bacteria are the only known source of BHPs (Kannenberg and Poralla, 1999). Although the biosynthesis of BHPs and their precursor, diploptene, does not require oxygen, the production of hopanoids was long assumed to be restricted to aerobic bacteria, as reports from facultatively or strictly anaerobic bacteria were initially missing. More recently, however, planctomycetes (Sinninghe Damsté et al., 2004), metal reducing Geobacter (Fischer et al., 2005), and sulfate reducing Desulfovibrio (Blumenberg et al., 2006; Blumenberg et al., 2009; Blumenberg et al., 2012) were identified as anaerobic producers of BHPs. In the Landsort Deep, cyanobacteria are abundant in the surface water layer and may be considered as a major source of BHPs (cf. Talbot et al., 2008; Welander et al., 2010). Evidence for such cyanobacterial BHP contributions may come from our analysis of a Gotland Deep bloom from summer 2012 (see 3.2.7). BHPs identified in this bloom were BHT, BHT cyclitol ether, and BHT glucosamine (Fig. 5b) which is in line with the BHP composition of the Landsort Deep surface layer (Fig. 5a). These three cyanobacterial BHPs were present throughout the Landsort Deep water column, although they were minor in the suboxic zone and below. In addition, the surface layer contained aminotriol that was also present in the whole water column. Aminotriol is an abundant BHP produced by various bacteria (e.g. Talbot and Farrimond, 2007, and references therein), indicating BHP sources other than cyanobacteria in the surface layer.

A further notable feature is the occurrence of BHT II at $70 \mathrm{~m}$ and below. The source of BHT II is not fully resolved yet. It was recently related to bacteria performing anaerobic ammonium oxidation in sediments (Rush et al., 2014), but two recent 
studies in the Landsort Deep could not give evidence for anammox in the water column of the Landsort Deep (Hietanen et al., 2012; Thureborn et al., 2013). BHT II was also described from stratified water columns of the Arabian Sea, Peru Margin and Cariaco Basin (Sáenz et al., 2011) Gotland Deep (Berndmeyer et al., 2013) and has therefore been proposed as a proxy for stratified water columns. This theory has positively been adopted to reconstruct the water column stratification in the Baltic Sea Holocene development (Blumenberg et al., 2013).

Like BHT II, aminotetrol and aminopentol are absent from the surface layer. Whereas both BHPs are biomarkers for methanotrophic bacteria, the latter typically occurs in type I methanotrophs (Talbot et al., 2001). The presence of type I methanotrophic bacteria is further supported by the co-occurrence of the specific 16:1 18 PLFA (Nichols et al., 1985; Bowman et al., 1991; Bowman et al., 1993) and its considerably depleted $\delta^{13} \mathrm{C}$ value $(-45.4 \% 0)$.

Whereas a major in situ production of BHPs in the suboxic zone is evident from our data, the sources of BHPs in the anoxic zone are more difficult to establish. BHPs in the anoxic zone may partly derive from sinking POM as well as being newly produced by anaerobic bacteria. The further may apply for BHT cyclitol ether and BHT glucosamine which seem to derive from cyanobacteria thriving in the oxic zone, as discussed above. Aminotriol, aminotetrol, and aminopentol, however, are known products of sulfate reducing bacteria (Blumenberg et al., 2006; Blumenberg et al., 2009; Blumenberg et al., 2012) and may have their origin within the anoxic zone. This interpretation is supported by the close correlation of the total BHPs with the ai-15:0 PLFA, which is considered as indicative for sulfate reducers (see 4.7.). Thus, the anoxic zone of the Landsort Deep is likely an active source for BHPs instead of solely being a pool for transiting compounds.

\subsubsection{Microbial processes in the anoxic zone}

Sulfate reducing bacteria were traced using ai-15:0 PLFA and 10-me-16:0 PLFA (Parkes and Taylor, 1983; Taylor and Parkes, 1983; Vainshtein et al., 1992). The high abundance of $a i-15: 0$ PLFA in the surface layer (Fig. 3) is surprising at first glance, as sulfate reducers are not supposed to thrive in oxic environments. However, these bacteria were previously reported from oxygenated surface waters of the Gotland Deep where they were associated with sinking cyanobacterial agglomerates (Gast 
and Gocke, 1988). 10-Me-16:0 PLFA, on the other hand, is absent from the oxic zone. This FA was reported to occur in Desulfobacter and Desulfobacula (Taylor and Parkes, 1983; Kuever et al., 2001), both strictly anaerobic organisms (Szewzyk and Pfennig, 1987; Widdel, 1987; Kuever et al., 2001). Indeed, Desulfobacula toluolica was genetically identified by Labrenz et al. (2007) in suboxic and anoxic waters of the central Baltic Sea.

In addition to the bacterial FA, two archaeal in situ biomarkers, archaeol and PMI, were identified. Archaeol is the most common ether lipid in archaea, but is especially abundant in euryarchaeotes, including methanogens (Tornabene and Langworthy, 1979; Koga et al., 1993). Likewise, PMI and its unsaturated derivatives are diagnostic for methanogenic euryarchaeotes (Tornabene et al., 1979; De Rosa and Gambacorta, 1988; Schouten et al., 1997). In the Landsort Deep, both compounds are virtually absent in the oxic zone, and increase in abundance with depth through the suboxic zone (Fig. 3). The same trend has been described for PMI in the Black Sea (Wakeham et al., 2007) and the presence of euryarchaeota in Landsort Deep anoxic waters has recently been proven by Thureborn et al. (2013).

Given the available sample resolution, it is impossible to further elucidate the exact distribution of archaea in the anoxic zone of the Landsort Deep. Likewise, $\delta^{13} \mathrm{C}$ values could not be obtained for archaeol and PMI due to low compound concentrations, which excludes statements on inputs of these lipids from archaea involved in the sulfate-dependent anaerobic oxidation of methane (AOM; cf. Hinrichs et al., 1999; Thiel et al., 1999; Pancost et al., 2001). Whereas it has been shown that $\mathrm{AOM}$ is theoretically possible in the anoxic zone of the Landsort Deep and anaerobic methane consumption was demonstrated to occur (Jakobs et al., 2013), a clear evidence for abundant $\mathrm{AOM}$ is as yet lacking and requires further investigations focused at the anoxic water bodies of the Baltic Sea.

\subsection{Conclusions}

The Landsort Deep in the western central Baltic Sea is characterized by a stratified water column. Marine microbial organisms have adapted to the vertical chemical limitations of their ecosystems and their distributions in the water column can be reconstructed using diverse in situ biomarkers. Within the oxic zone, a clear preference for the surface layer became obvious for distinctive biomarkers. 
7-methylheptadecane, different alkenes and the BHPs BHT cyclitol ether and BHT glucosamine indicated the presence of cyanobacteria. Dinosterol concentrations and $\delta^{13} \mathrm{C}$ values not only supported a phototrophic dinoflagellate population in the surface, but a second, heterotrophic community at the suboxic-anoxic interface. Similarly, tetrahymanol was most abundant at the surface, indicating ciliates feeding on cyanobacterial agglomerates, but showed a second maximum at the suboxicanoxic interface where ciliates graze on chemo-autotrophic bacteria. The cold winter water layer at the bottom of the oxic zone showed only low concentrations of biomarkers and seemed to be avoided by most organisms, except copepods. In contrast, biomarkers in the suboxic zone reflected a high abundance and diversity of

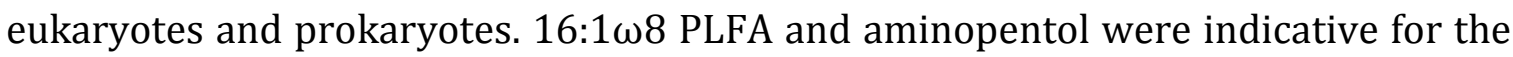
presence of type I aerobic methane oxidizing bacteria whereas ai-15:0 PLFA, 10-me-16:0 and total BHPs indicated the distribution of sulfate reducing bacteria in the Landsort Deep water column. ai-15:0 PLFA was also present in the surface layer, indicating sulfate reducers associated with cyanobacteria agglomerates. The close coupling of ai-15:0 PLFA with total BHPs make these bacteria a likely in situ source for hopanoids in the anoxic zone. The anoxic zone was further inhabited by archaea, as shown by the presence of archaeol and PMI and its derivatives. Our study of in situ biomarkers in the water column of the Landsort Deep thus provided a better insight into the distribution of relevant players and the related biogeochemical processes. Yet, still only little is known about the microorganisms, their distribution, and their metabolisms in the anoxic zone. Thus, further studies in the anoxic part of the water column would be of great interest for an advanced understanding of microbial communities in the central Baltic Sea.

\section{Acknowledgments}

We thank the Captains and crews of R/Vs Elisabeth Mann Borghese and Meteor for assistance during the cruises. We thank C. Conradt and L. Kammel for laboratory assistance, and T. Licha and K. Nödler for help with LC-MS. The German Research Foundation (Deutsche Forschungsgemeinschaft, DFG) is acknowledged for financial support (Grants BL 971/1-3 and 971/3-1). 


\section{References}

Anderson, R., Winter, C., Jürgens, K., 2012. Protist grazing and viral lysis as prokaryotic mortality factors at Baltic Sea oxic-anoxic interfaces. Marine Ecology Progress Series 467, 1-14.

Beliaeff, B. and Burgeot, T., 2001. Integrated biomarker response: a useful tool for ecological risk assessment. Environmental Toxicology and Chemistry 21, 1316-1322.

Bergström, S. and Matthäus, W., 1996. Meteorology, hydrology and hydrography. HELCOM, Helsinki, 1996.

Berndmeyer, C., Thiel, V., Schmale, O., Blumenberg, M., 2013. Biomarkers for aerobic methanotrophy in the water column of the stratified Gotland Deep (Baltic Sea). Organic Geochemistry 55, 103-111.

Bi, X., Sheng, G., Liu, X., Li, C., Fu, J., 2005. Molecular and carbon and hydrogen isotopic composition of $n$-alkanes in plant leaf waxes. Organic Geochemistry 36, 1405-1417.

Blumenberg, M., Krüger, M., Nauhaus, K., Talbot, H. M., Oppermann, B. I., Seifert, R., Pape, T., Michaelis, W., 2006. Biosynthesis of hopanoids by sulfate-reducing bacteria (genus Desulfovibrio). Environmental Microbiology 8, 1220-1227.

Blumenberg, M., Seifert, R., Michaelis, W., 2007. Aerobic methanotrophy in the oxicanoxic transition zone of the Black Sea water column, Organic Geochemistry 38, 8491.

Blumenberg, M., Oppermann, B. I., Guyoneaud, R., Michaelis, W., 2009. Hopanoid production by Desulfovibrio bastinii isolated from oilfield formation water. FEMS Microbiology Letters 293, 73-78.

Blumenberg, M., Hoppert, M., Krüger, M., Dreier, A., Thiel, V., 2012. Novel findings on hopanoid occurrences among sulfate reducing bacteria: Is there a direct link to nitrogen fixation? Organic Geochemistry 49, 1-5.

Blumenberg, M., Berndmeyer, C., Moros, M., Muschalla, M., Schmale, O., Thiel, V., 2013. Bacteriohopanepolyols record stratification, nitrogen fixation and other 
biogeochemical perturbations in Holocene sediments of the central Baltic Sea. Biogeosciences, 10, 2725-2735.

Boon, J. J., Rijpstra, W. I. C., De Lange, F., De Leeuw, J. W., 1979. Black Sea sterol - a molecular fossil for dinoflagellate blooms. Nature, 277, 125-127.

Boschker, H. T. S. and Middelburg, J. J., 2001. Stable isotopes and biomarkers in microbial ecology. FEMS Microbiology Ecology 40, 85-95.

Bowman, J. P., Skeratt, J. H., Nichols, P. D., Sly, L. I., 1991. Phopsholipid fatty acid and lipopolysaccharide fatty acid signature lipids in methane-utilizing bacteria. FEMS Microbiology Ecology 85, 15-22.

Bowman, J. P., Sly, L. I., Nichols, P. D., Hayward, A. C., 1993. Revised taxonomy of the methanotrophs: Description of Methylobacter gen. nov., emendation of Methylococcus, validation of Methylosinus and Methylocystis species, and a proposal that the family Methylococcaceae includes only the group I methanotrophs. International Journal of Systematic Bacteriology 43, 735-753.

Carlson, D. R., Roan, C.-S., Yost, R. A., Hector, J., 1989. Dimethyl disulfide derivatives of long chain alkenes, alkadiens, and alkatrienes for gas chromatography / mass spectrometry. Analytical Chemistry 61, 1564-1571.

Conner, R. L., Landrey, J. R., Burns, C. H., Mallory, F. B., 1968. Cholesterol inhibition of pentacyclic triterpenoid biosythesis in Tetrahymena pyriformis, Journal of Protozoology 15, 600-605.

De Rosa, M. and Gambacorta, A., 1988. The lipids of archaebacteria. Progress in Lipid Research 27, 153-175.

Dellwig, O., Leipe, T., März, C., Glockzin, M., Pollehne, F., Schnetger, B., Yakushev, E. V., Böttcher, M. E., Brumsack, H.-J., 2010. A new particulate Mn-Fe-P-shuttle at the redoxcline of anoxic basins. Geochimica et Cosmochimica Acta 74, 7100-7115.

Detmer, A. E., Giesenhagen, H. C., Trenkel, V. M., Auf dem Venne, H., Jochem, F., 1993. Phototrophic and hetreotrophic pico- and nanoplankton in anoxic depths of the central Baltic Sea. Marine Ecology Progress Series 99, 197-203. 
Eglinton, G. and Hamilton, R. J., 1967. Leaf epicuticular waxes. Science, 156, 13221335.

Falk-Petersen, S., Dahl, T. M., Scott, C. L., Sargent, J. R., Gulliksen, B., Kwasniewski, S., Hop, H., Millar, R.-M., 2002. Lipid biomarkers and trophic linkages between ctenophores and copepods in Svalbard waters. Marine Ecology Progress Series 227, 187-194.

Findlay, R. H. and Dobbs, F. C., 1993. Quantitative description of microbial communities using lipid analysis. In: Cole, J. J. (Ed.). Handbook of methods in aquatic microbial ecology. CRC Press, Florida, USA, 1993.

Fischer, W. W., Summons, R. E., Pearson, A., 2005. Targeted genomic detection of biosynthetic pathways: anaerobic production of hopanoid biomarkers by a common sedimentary microbe. Geobiology, 3, 33-40.

Gaskell, S. J. and Eglinton, G., 1975. Rapid hydrogenation of sterols in a contemporary lacustrine sediment. Nature, 254, 209-211, 1975.

Gast, V. and Gocke, K., 1988. Vertical distribution of number, biomass and size-class spectrum of bacteria in relation to oxic/anoxic conditions in the Central Baltic Sea. Marine Ecology Progress Series 45, 179-186.

Gatellier, J.-P. L. A., de Leeuw, J. W., Sinninghe Damsté, J. S., Derenne, S., Largeau, C., Metzger, P., 1993. A comparative study of macromolecular substances of a Coorongite and cell walls of the extant alga Botryococcus braunii, Geochimica et Cosmochimica Acta 57, 2053-2068.

Gelpi, E., Schneider, H., Mann, J., Oró, J., 1970. Hydrocarbons of geochemical significance in microscopic algae. Phytochemistry 9, 603-612.

Hajdu, S., Höglander, H., Larsson, U., 2007. Phytoplankton vertical distributions and compositions in Baltic Sea cyanobacterial blooms. Harmful Algae 6, 189-205.

Hanson, N., Förlin, L., Larsson, Â., 2009. Evaluation of long-term biomarker data from perch (Perca fluviatilis) in the Baltic Sea suggests increasing exposure to environmental pollutants. Environmental Toxicology and Chemistry 28, 364-373. 
Hebting, Y., Schaeffer, P., Behrens, A., Adam, P., Schmitt, G., Schneckenburger, P., Bernasconi, S. M., Albrecht, P., 2006. Biomarker evidence for a major preservation pathway of sedimentary organic carbon. Science 312, 1627-1631.

Hietanen, S., Jäntti, H., Buizert, C., Jürgens, K., Labrenz, M., Voss, M., Kuparinen, J., 2012. Hypoxia and nitrogen processing in the Baltic Sea water column. Limnology and Qceanography 57, 325-337.

Hinrichs, K. U., Hayes, J. M., Sylva, S. P., Brewer, P. G., DeLong, E. F., 1999. Methaneconsuming archaebacteria in marine sediments. Nature 398, 802-805.

Höglander, H., Larsson, U., Hajdu, S., 2004. Vertical distribution and settling of spring phytoplankton in the offshore NW Baltic Sea proper. Marine Ecology Progress Series 283, 15-27.

Jakobs, G., Rehder, G., Jost, G., Kießlich, K., Labrenz, M., Schmale, O., 2013. Comparative studies of pelagic microbial methane oxidation within the redox zones of the Gotland Deep and Landsort Deep (central Baltic Sea). Biogeosciences 10, 7863-7875.

Jakobs, G., Holtermann, P., Berndmeyer, C., Rehder, G., Blumenberg, M., Jost, G., Nausch, G., Schmale, O., 2014. Seasonal and spatial methane dynamic in the water column of the central Baltic Sea (Gotland Sea), Continental Shelf Research, under review.

Kamyshny Jr., A., Yakushev, E. V., Jost, G., Podymov, O. I., 2013. Role of sulfide oxidation intermediates in the redox balance of the oxic-anoxic interface of the Gotland Deep, Baltic Sea. In: Yakushev, E. V. (Ed.). The handbook of environmental chemistry. Springer, Berlin Heidelberg, 95-119, 2013.

Kannenberg, E. L. and Poralla, K., 1999. Hopanoid biosythesis and function in bacteria. Naturwissenschaften 86, 168-176.

Kattner, G. and Krause, M., 1989. Seasonal variations of lipids (wax esters, fatty acids and alcohols) in calanoid copepods from the North Sea, Marine Chemistry 26, 261275. 
Koga, Y., Nishihara, M., Morii, H., Akagawa-Matsushita, M., 1993. Ether polar lipids of methanogenic bacteria: structures, comparative aspects, and biosynthesis. Microbiological Reviews 57 164-182.

Kononen, K., Kuparinen, J., Mäkelä, K., Laanemets, J., Pavelson, J., Nõmman, S., 1996. Initiation of cyanobacterial blooms in a frontal region at the entrance to the Gulf of Finland, Baltic Sea. Limnology Oceanography 41, 98-112.

Köster, J., Volkman, J. K., Rullkötter, J., Scholz-Böttcher, B. M., Rethmeier, J., Fischer, U., 1999. Mono-, di- and trimethyl-branched alkanes in cultures of the filamentous cyanobacterium Calothrix scopulorum. Organic Geochemistry 30, 1367-1379.

Kuever, J., Könnecke, M., Galushko, A., Drzyzga, 0., 2001. Reclassification of Desulfobacterium phenolicum as Desulfobacula phenolica comb. nov. and description of strain $\operatorname{Sax}^{\mathrm{T}}$ as Desulfotignum balticum gen. nov., sp. nov. International Journal of Systematic and Evolutionary Microbiology 51, 171-177.

Labrenz, M., Jost, G., Jürgens, K., 2007. Distribution of abundant prokaryotic organsims in the water column of the central Baltic Sea with an oxic-anoxic interface. Aquatic Microbial Ecology 46, 177-190.

Lang, I., Hodac, L., Friedl, T., Feussner, I., 2011. Fatty acid profiles and their distribution patterns in microalgae: a comprehensive analysis of more than 2000 strains from the SAG culture collection. BMC Plant Biology 11, 124-140.

Leblond, J. D., Anderson, B., Kofink, D., Logares, R., Rengefors, K., Kremp, A., 2007. Fatty acid and sterol composition of two evolutinary closely related dinoflagellate morphospecies from cold Scandinavian brackish and freshwaters. European Journal of Phycology 41, 303-311.

Lee, R. F., Nevenzel, J. C., Paffenhöfer, G.-A., 1971. Importance of wax esters and other lipids in the marine food chain: phytoplankton and copepods. Marine Biology 9, 99108.

Lehtonen, K. K., Schiedek, D., Köhler, A., Lang, T., Vuorinen, P. J., Förlin, L., Baršienė, J., Pempkowiak, J., Gercken, J., 2006. The BEEP project in the Baltic Sea: Overview of 
results and outline for a regional biological effects monitoring strategy. Marine Pollution Bulletin 53, 523-537.

Liu, A., Zhu, T., Lu, X., Song, L., 2013. Hydrocarbon profiles and phylogenetic analyses of diversified cyanobacterial species. Applied Energy 111, 383-393.

Mansour, M. P., Volkman, J. K., Jackson, A. E., Blackburn, S. I., 1999. The fatty acid and sterol composition of five marine dinoflagellates. Journal of Phycology 35, 710-720.

Matsumoto, G. I., Akiyama, M., Watanuki, K., Torii, T., 1990. Unusual distribution of long-chain $n$-alkanes and $n$-alkenes in Antarctic soil. Organic Geochemistry 15, 403412.

Matthäus, W. and Schinke, H., 1999. The influence of river runoff on deep water conditions of the Baltic Sea. Hydrobiologia 393, 1-10.

Möllmann, C., Kornilovs, G., Sidrevics, L., 2000. Long-term dynamics of main mesozooplankton species in the central Baltic Sea. Journal of Plankton Research 22, 2015-2038.

Möllmann, C. and Köster, F. W., 2002. Population dynamics of calanoid copepods and the implications of their predation by clupeid fish in the Central Baltic Sea. Journal of Plankton Research 24, 959-977.

Nanton, D. A. and Castell, J. D., 1999. The effects of temperature and dietary fatty acids on the fatty acid composition of harpacticoid copepods, for use as a live food for fish larvae. Aquaculture 175, 167-181.

Nichols, P. D., Smith, G. A., Antworth, C. P., Hanson, R. S., White, D. C., 1985. Phospholipid and lipopolysaccharide normal and hydroxy fatty acids as potential signatures for methane-oxidizing bacteria. FEMS Microbiology Ecology 0, 327-335.

Pancost, R. D., Hopmans, E. C., Sinninghe Damsté, J. S., s. s. party, T. M., 2001. Archaeal lipids in Mediterranean cold seeps: molecular proxies for anaerobic methane oxidation. Geochimica et Cosmochimica Acta 65, 1611-1627. 
Parkes, R. J. and Taylor, J., 1983. The relationship between fatty acid distributions and bacterial respiratory types in contemporary marine sediments. Estuarine, Coastal and Shelf Science 16, 173-189.

Parrish, C. C., Bodennec, G., Gentien, P., 1994. Time courses of intracellular and extracellular lipid classes in batch cultures of the toxic dinoflagellate, Gymnodinium cf. nagasakiense. Marine Chemisty 48, 71-82.

Parrish, C. C., Abrajano, T. A., Budge, S. M., Helleur, R. J., Hudson, E. D., Pulchan, K., Ramos, C., 2000. Lipid and Phenolic Biomarkers in Marine Ecosystems: Analysis and Applications. In: Wangersky, P. J. (Ed.). The Handbook of Environmental Chemistry. Springer Berlin Heidelberg, 193-223, 2000.

Pinkart, H. C., Ringelberg, D. B., Piceno, Y. M., Macnaughton, S. J., White, D. C., 2002. Biochemical approaches to biomass measurements and community structure analysis. In: Hurt, C. J. (Ed.). Manual of environmental microbiology, 2nd ed. ASM Press, Washington, DC, 101-113, 2002.

Pugh, P. R., 1971. Changes in the fatty acid composition of Coscinodiscus eccentricus with cultur-age and salinity. Marine Biology 11, 118-124.

Reissmann, J. H., Burchard, H., Feistel, R., Hagen, E., Lass, H. U., Mohrholz, V., Nausch, G., Umlauf, L., Wieczorek, G., 2009. State-of-the-art review on vertical mixing in the Baltic Sea and consequences for eutrophication. Progress in Oceanography 82, 4780.

Risse-Buhl, U., Trefzeger, N., Seifert, A.-G., Schönborn, W., Gleixner, G., Küsel, K., 2011. Tracking the autochthonous carbon transfer in stream biofilm food webs. FEMS Microbiology Ecology 79, 118-131.

Rush, D., Sinninghe Damsté, J. S., Poulton, S. W., Thamdrup, B., Garside, A. L., González, J. A., Schouten, S., Jetten, M. S. M., Talbot, H. M., 2014. Anaerobic ammonium-oxidising bacteria: a biological source of the bacteriohopanetetrol stereoisomer in marine sediments. Geochimica et Cosmochimimica Acta 140, 50-64. 
Sáenz, J. P., Wakeham, S. G., Eglinton, T. I., Summons, R. E., 2011. New constraints on the provenance of hopanoids in the marine geologic record: Bacteriohopanepolyols in marine suboxic and anoxic environments. Organic Geochemisty 42, 1351-1362.

Sargent, J. R., Gatten, R. R., McIntosh, R., 1977. Wax esters in the marine environment - their occurence, formation, transformation and ultimate fates. Marine Chemistry 5, 573-584.

Schmale, O., Blumenberg, M., Kießlich, K., Jakobs, G., Berndmeyer, C., Labrenz, M., Thiel, V., Rehder, G., 2012. Microbial methane oxidation at the redoxcline of the Gotland Deep (Baltic Sea). Biogeosciences 9, 4969-4977.

Schneider, B., Nausch, G., Kubsch, H., Petersohn, I., 2002. Accumulation of total $\mathrm{CO}_{2}$ during stagnation in the Baltic Sea deep water and its relationship to nutrient and oxygen concentrations. Marine Chemistry 77, 277-291.

Schouten, S., Van der Maarel, M. J. E. C., Huber, R., Sinninghe Damsté, J. S., 1997. 2,6,10,15,19-Pentamethylicosenes in Methanolobus bombayensis, a marine methanogenic archaeon, and in Methanosarcina mazei. Organic Geochemistry 26, 409-414.

Schouten, S., Wakeham, S. G., Sinninghe Damsté, J. S., 2001. Evidence for anaerobic methane oxidation by archaea in euxinic waters of the Black Sea. Organic Geochemistry 32, 1277-1281.

Schubert, C. J., Coolen, M. J., Neretin, L. N., Schippers, A., Abbas, B., Durisch-Kaiser, E., Wehrli, B., Hopmans, E. C., Damste, J. S., Wakeham, S., Kuypers, M. M., 2006. Aerobic and anaerobic methanotrophs in the Black Sea water column. Environmental Microbiology 8, 1844-1856.

Shamsudin, L., 1992. Lipid and fatty acid composition of microalgae used in Malaysian aquaculture as live food for the early stage of penaeid larvae. Journal of Applied Phycology 4, 371-378.

Shiea, J., Brassel, S. C., Ward, D. M., 1990. Mid-chain branched mono- and dimethyl alkanes in hot spring cyanobacterial mats: A direct biogenic source for branched alkanes in ancient sediments? Organic Geochemistry 15, 223-231. 
Sinninghe Damsté, J. S., Rijpstra, W. I. C., Schouten, S., Fuerst, J. A., Jetten, M. S. M., Strous, M., 2004. The occurrence of hopanoids in planctomycetes: implications for the sedimentary biomarker record. Organic Geochemistry 35, 561-566.

Stal, L. J., Albertano, P., Bergmann, B., von Bröckel, K., Gallon, J. R., Hayes, P. K., Sivonen, K., Walsby, A. E., 2003. BASIC: Baltic Sea cyanobacteria. An investigation of the structure and dynamics of water blooms of cyanobacteria in the Baltic Sea responses to a changing environment. Continental Shelf Research 23, 1695-1714.

Stock, A., Jürgens, K., Bunge, J., Stoeck, T., 2009. Protistan diversity in suboxic and anoxic waters of the Gotland Deep (Baltic Sea) as revealed by $18 \mathrm{~S}$ rRNA clone libraries. Aquatic Microbial Ecology 55, 267-284.

Strom, S. L. and Morello, T. A., 1998. Comparative growth rates and yields of ciliates and heterotrophic dinoflagellates. Journal of Plankton Research 20, 571-584.

Sturt, H. F., Summons, R. E., Smith, K., Elvert, M., Hinrichs, K. U., 2004. Intact polar membrane lipids in prokaryotes and sediments deciphered by high-performance liquid chromatography/electrospray ionization multistage mass spectrometry - new biomarkers for biogeochemistry and microbial ecology. Rapid Communications in Mass Spectrometry 18, 617-628.

Szewzyk, R. and Pfennig, N., 1987. Complete oxidation of catechol by the strictly anaerobic sulfate-reducing Desulfobacterium catecholicum sp. nov. Archives of Microbiology 147, 163-168.

Talbot, H. M., Watson, D. F., Murrel, J. C., Carter, J. F., Farrimond, P., 2001. Analysis of intact bacteriohopanepolyols from methanotrophic bacteria by reversed-phase highperformance liquid chromatography-atmospheric pressure chemical ionisation mass spectrometry. Journal of Chromatography 921, 175-185.

Talbot, H. M. and Farrimond, P., 2007. Bacterial populations recorded in diverse sedimentary biohopanoid distributions. Organic Geochemistry 38, 1212-1225.

Talbot, H. M., Summons, R. E., Jahnke, L. L., Cockell, C. S., Rohmer, M., Farrimond, P., 2008. Cyanobacterial bacteriohopanepolyol signatures from cultures and natural environmental settings. Organic Geochemistry 39, 232-263. 
Taylor, J. and Parkes, J., 1983. The cellular fatty acids of the sulphate-reducing bacteria, Desulfobacter sp., Desulfobulbus sp. and Desulfovibrio desulfuricans. Journal of General Microbiology 129, 3303-3309.

Thiel, V., Peckmann, J., Seifert, R., Wehrung, P., Reitner, J., Michaelis, W., 1999. Highly isotopically depleted isoprenoids: molecular markers for ancient methane venting. Geochimica et Cosmochimica Acta 63, 3959-3966.

Thureborn, P., Lundin, D., Plathan, J., Poole, A. M., Sjöberg, B.-M., Sjöling, S., 2013. A metagenomics transect into the deepest point of the Baltic Sea reveals clear stratification of microbial functional capacities. PLOS One 8 (9), e74983.

Tornabene, T. G. and Langworthy, T. A., 1979. Diphytanyl and dibiphytanyl glycerol ether lipids of methanogenic archaebacteria. Science 203, 51-53.

Tornabene, T. G., Langworthy, T. A., Holzer, G., Orò, J., 1979. Sqalenes, phytanes and other isoprenoids as major neutral lipids of methanogenic and thermoacidophilic "archaebacteria". Journal of Molecular Evolution 13, 73-83.

Tyson, R. V. and Pearson, T. H., 1991. Modern and ancient continental shelf anoxia: an overview. Geological Society, London, Special Publications 58, 1-24.

Vahtera, E., Conley, D. J., Gustafsson, B. G., Kuosa, H., Pitkänen, H., Savchuk, O. P., Tamminen, T., Viitasalo, M., Voss, M., Wasmund, N., Wulff, F., 2007. Internal ecosystem feedbacks enhance nitrogen-fixing cyanobacteria blooms and complicate management in the Baltic Sea. AMBIO 36, 186-194.

Vainshtein, M., Hippe, H., Kroppenstedt, R. M., 1992. Cellular fatty acid composition of Desulfovibrio species and its use in classification of sulfate-reducing bacteria. Systematic and Applied Microbiology 15, 554-556.

Vestal, R. J. and White, D. C., 1989. Lipid analysis in microbial ecology. BioScience 39, 535-541.

Volkman, J. K., 1986. A review of sterol markers for marine and terrigenous organic matter. Organic Geochemistry 9, 83-99. 
Volkman, J. K., Barrett, S. M., Dunstan, G. A., Jeffrey, S. W., 1993. Geochemical significance of the occurrence of dinosterol and other 4-methyl sterols in a marine diatom. Organic Geochemistry 20, 7-15.

Volkman, J. K., Barrett, S. M., Blackburn, S. I., Mansour, M. P., Sikes, E. L., Gelin, F., 1998. Microalgal biomarkers: A review of recent research developments. Organic Geochemistry 29, 1163-1179.

Wakeham, S. G., 1989. Reduction of stenols to stanols in particulate matter at oxicanoxic boundaries in sea water. Nature 342, 787-790.

Wakeham, S. G., Amann, R., Freeman, K. H., Hopmans, E. C., Jørgensen, B. B., Putnam, I. F., Schouten, S., Sinninghe Damsté, J. S., Talbot, H. M., Woebken, D., 2007. Microbial ecology of the stratified water column of the Black Sea as revealed by a comprehensive biomarker study. Organic Geochemistry 38, 2070-2097.

Wakeham, S. G., Turich, C., Schubotz, F., Podlaska, A., Xiaona, N. L., Varela, R., Astor, Y., Sáenz, J. P., Rush, D., Sinninghe Damsté, J. S., Summons, R. E., Scranton, M. I., Taylor, G. T., Hinrichs, K. U., 2012. Biomarkers, chemistry and microbiology show chemoautotrophy in a multilayer chemocline in the Cariaco Basin. Deep Sea Research Part I 163, 133-156.

Wasmund, N., Nausch, G., Matthäus, W., 1998. Phytoplankton spring blooms in the southern Baltic Sea - spatio temporal development and long-term trends. Journal of Plankton Research 20, 1099-1117.

Welander, P. V., Coleman, M., Sessions, A. L., Summons, R. E., Newman, D. K., 2010. Identification of a methylase required for 2-methylhopanoid production and implications for the interpretation of sedimentary hopanes. PNAS 107, 8537-8542.

Widdel, F., 1987. New types of acetate-oxidizing, sulfate-reducing Desulfobacter species, D. hydrogenophilus sp. nov., D. latus sp. nov., and D. curvatus sp. nov. Archives of Microbiology 148, 286-291.

Xie, S., Liu, X.-L., Schubotz, F., Wakeham, S. G., Hinrichs, K. U., 2014. Distribution of glycerol ether lipids in the oxygen minimum zone of the Eastern Tropical North Pacific Ocean. Organic Geochemistry 71, 60-71. 


\title{
Aerobic methanotrophy within the pelagic redox-zone of the Gotland Deep (central Baltic Sea)
}

\author{
Oliver Schmale, Martin Blumenberg, Kathrin Kießlich, Gunnar Jakobs, Christine \\ Berndmeyer, Matthias Labrenz, Volker Thiel, and Gregor Rehder \\ Biogeosciences (2012) 9: 4969-4977. \\ DOI:10.5194/bg-9-4969-2012, Open Access
}

\subsection{Abstract}

Water column samples taken in summer 2008 from the stratified Gotland Deep (central Baltic Sea) showed a strong gradient in dissolved methane concentrations from high values in the saline deep water (max. $504 \mathrm{nM}$ ) to low concentrations in the less dense, brackish surface water (about $4 \mathrm{nM}$ ). The steep methane-gradient (between 115 and 135m water depth) within the redox-zone, which separates the anoxic deep part from the oxygenated surface water (oxygen concentration 0-0.8 $\mathrm{mL} \mathrm{L} \mathrm{L}^{-1}$ ), implies a methane consumption rate of $0.28 \mathrm{nM} \mathrm{d}^{-1}$. The process of microbial methane oxidation within this zone was evident by a shift of the stable carbon isotope ratio of methane between the bottom water $\left(\delta^{13} \mathrm{C} \mathrm{CH}_{4}=-82.4 \% 0\right)$ and the redoxzone $\left(\delta^{13} \mathrm{C} \mathrm{CH}_{4}=-38.7 \%\right.$ ). Water column samples between 80 and $119 \mathrm{~m}$ were studied to identify the microorganisms responsible for the methane turnover in that depth interval. Notably, methane monooxygenase gene expression analyses for water depths covering the whole redox-zone demonstrated that accordant methanotrophic activity was probably due to only one phylotype of the aerobic type I methanotrophic bacteria. An imprint of these organisms on the particular organic matter was revealed by distinctive lipid biomarkers showing bacteriohopanepolyols and lipid fatty acids characteristic for aerobic type I methanotrophs (e.g., 35-aminobacteriohopane-30,31,32,33,34-pentol), corroborating their role in aerobic methane oxidation in the redox-zone of the central Baltic Sea. 


\subsection{Introduction}

Methane as an atmospheric trace gas is known to have a relevant impact on Earth's climate. Aquatic systems represent the most significant source of atmospheric methane. However, the importance of the marine system seems to be marginal (Bange et al., 1994), although enormous amounts of methane are formed in marine sediments (Reeburgh, 2007). One effective mechanism that is limiting the flux of methane from the sedimentary reservoir into the atmosphere is the microbial oxidation of methane in the sediment and the water column (Reeburgh, 2007). Comprehensive studies on aquatic sediments in different settings show that methane is microbially oxidized by the use of different electron acceptors, with oxygen being most important for the water column and sulfate for the sedimentary turnover (Barnes and Goldberg, 1976; Reeburgh, 1976; Hinrichs and Boetius, 2002; Reeburgh, 2007). Recently, anaerobic methane oxidation using iron, manganese and nitrite has also been reported (Beal et al., 2009; Ettwig et al., 2010). Although these processes are efficient and consume the main part of dissolved methane before it escapes from the sediment/water interface, some parts of the ocean are characterised by strongly elevated methane concentrations in the water column. This holds particularly true for stagnant, oxygen-deficient basins like the Black Sea, Cariaco Basin or central Baltic Sea (Scranton et al., 1993; Kessler et al., 2006; Schmale et al., 2010a). Compared to the number of studies on the microbial processes of methane oxidation in sediments, water column studies are scarce, and could to date just identify the oxidation of methane through oxygen and sulfate (Reeburgh, 2007 and references therein). Nevertheless, multidisciplinary studies in the water column of the Black Sea could impressively demonstrate that the flux of methane from the deep-water reservoir into the atmosphere is effectively buffered by the microbial oxidation of methane under anaerobic and aerobic conditions (Schouten et al., 2001; Schubert et al., 2006; Wakeham et al., 2007; Blumenberg et al., 2007; Schmale et al., 2011).

Our present investigations were carried out in the Gotland Deep in the central part of the Baltic Sea (Fig. 1). The Baltic Sea is a European semi-enclosed marginal sea characterized by limnic to brackish surface water and more saline deep and bottom water. Especially for the central deep basins of the Baltic Sea, this results in limited vertical mixing, the development of a prominent redox-zone with oxic to anoxic 
conditions, and the formation of stable biogeochemical zones (Nausch et al., 2008). In these basins, the stagnant deep water can only be renewed by strong temporal inflow events of saline oxygenated water from the North Sea (Reissmann et al., 2009) or by long-term vertical transport mechanisms mainly induced by bottom boundary mixing along the sloping

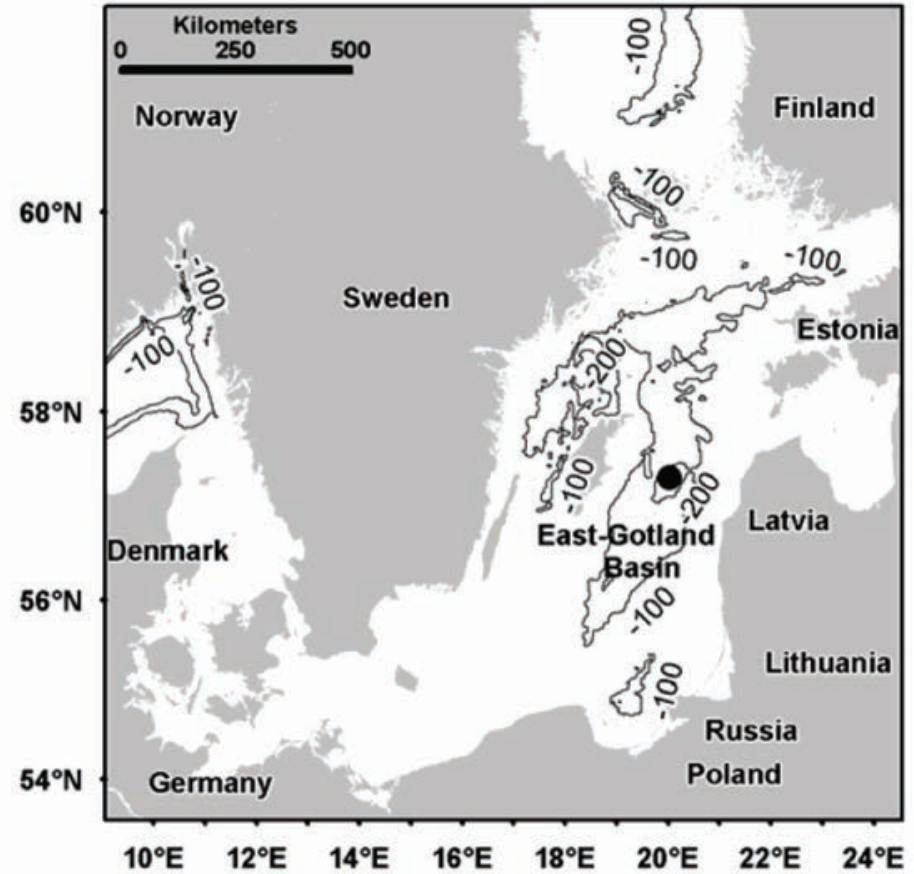

Fig. 1: The Baltic Sea and the location of the Gotland Deep. The study area is indicated with a black dot.

topography (Holtermann

and Umlauf, 2012). More frequent are weak inflows of North Sea water that are periodically perturbing the intermediate water column stratification and biogeochemical zones in the central basins (Matthäus et al., 2008). The Baltic Sea, like other marginal seas, is characterized by high terrestrial inputs and production rates of organic matter that are to a considerable extent accumulated and decomposed in the sediment. Under anoxic conditions, the final step of decomposition of organic matter leads to the generation of methane within the sediment. In the Baltic Sea, pore-water as well as acoustic investigations demonstrated that methane is abundant in high concentrations within the sediment and that in some regions methane is also released as free or dissolved gas into the water column (Dando et al., 1994; Piker et al., 1998; Thießen et al., 2006). Extensive water column investigations in the Baltic Sea identified the strongest methane enrichment within the stagnant anoxic water bodies of the deep basins (Gotland Deep and Landsort Deep; max. $504 \mathrm{nM}$ at $230 \mathrm{~m}$ water depth and $1058 \mathrm{nM}$ at $435 \mathrm{~m}$ water depth, respectively; Schmale et al., 2010b). In contrast, surface water methane concentrations in these areas are only slightly enriched compared to the atmospheric equilibrium, indicating an effective sink that prevents the escape of 
methane from the deep water into the atmosphere (Schmale et al., 2010b). However, little is as yet known about the processes that regulate the methane flux in this environment. In this paper, we use a multidisciplinary approach that combines gas chemistry, molecular biology and lipid biomarker geochemistry and present data on a microbial methane sink within the pelagic redox-zone of the Gotland Deep. Thus, this study aims to investigate whether aerobic methane oxidation also plays a role in the more dynamic and turbulent redox-zone of the central Baltic Sea.

\subsection{Methods}

Samples were retrieved during a scientific cruise in summer 2008 with the German research vessel Maria S. Merian (MSM 08/3, 18 June to 18 July. The Gotland Deep (57 $18^{\prime}$ N, $20^{\circ} 04^{\prime}$ E; Fig. 1) represents the deepest location in the eastern Gotland Basin (water depth at our water station $231 \mathrm{~m}$ ). The sampling strategy at this location was directed at (1) identifying the depth interval of aerobic methane oxidation within the redox-zone based on physical parameters and on board gas chemistry, and (2) recovering samples from the relevant depth interval for homebased molecular biological and lipid biomarker studies to identify the microorganisms involved in methane oxidation. These samples were taken within a time frame of 3 days and with different sampling equipment (as described below).

\subsubsection{Physical parameters and gas chemistry}

Water stations for analyses of the gas chemistry were carried out with a rosette water sampler equipped with twenty-four 10 L Hydro-bios Free Flow bottles. For continuous CTD and turbidity profiling a Seabird sbe911+ system, together with a turbidity sensor (ECO FLNTU, WET Labs) were attached to the underwater unit.

The oxygen distribution was measured according to Winkler's method, whereas hydrogen sulfide was analysed colorimetrically with the methylene blue method (Grasshoff et al., 1983).

Water samples $(600 \mathrm{~mL})$ for methane analyses were transferred directly from the sample bottle into pre-evacuated $1100 \mathrm{~mL}$ glass bottles. Dissolved methane was extracted using a vacuum degassing method and its mole fraction was determined with a gas chromatograph equipped with a flame ionisation detector (Trace GC, Thermo Electron). The average precision of this method is $\pm 3 \%$ (Keir et al., 2009). 
For the determination of $\delta^{13} \mathrm{C} \mathrm{CH}_{4}$ values, subsamples of the extracted gas were analysed at the Leibniz Institute for Baltic Sea Research Warnemünde using an isotope-ratio mass spectrometer (modified after Schmale et al., 2010a). These subsamples were collected in $10 \mathrm{~mL}$ pre-evacuated crimp-top glass vials containing $4 \mathrm{~mL}$ of supersaturated salt solution (degassed Millipore water, poisoned with $\mathrm{HgCl}_{2}$ ) and sealed with a butyl rubber septum. Stable carbon isotope analysis involved removal of water and carbon dioxide on a $\mathrm{NaOH} /$ Ascarite trap, double cryofocusing at $-110^{\circ} \mathrm{C}$ (ethanol/nitrogen) on Hayesep D and Poraplot S columns, gas-release by heating the traps separately to $40{ }^{\circ} \mathrm{C}$ and gas separation on a MolSieve 5A Plot capillary column (Supelco, $30 \mathrm{~m}$, I.D. $0.32 \mathrm{~mm}$ ) at $30^{\circ} \mathrm{C}$ (Trace GC Ultra, Thermo Electron), combustion to $\mathrm{CO}_{2}$ using a $\mathrm{Ni}$ catalyst at $1050{ }^{\circ} \mathrm{C}$, removal of combustion water using a Nafion trap, and injection into a MAT 253 mass spectrometer (Thermo Electron, Bremen) using a continuous flow technique. The $\delta^{13} \mathrm{C} \mathrm{CH}_{4}$ data is expressed vs. Vienna Pee Dee Belemnite (VPDB) standard. Calibration of the system was performed daily by the use of a $\mathrm{CH}_{4}$ standard with known isotopic composition. The average precision of that method is $\pm 1 \%$.

\subsection{2 pmoA gene expression analyses}

Within the identified redox-zone filter samples were taken in 80, 100, 105 and 119 $\mathrm{m}$ water depth using a rosette water sampler. $1000 \mathrm{~mL}$ of sample water were filtered on a Durapore filter $(0.2 \mu \mathrm{m}$ pore size), frozen in liquid nitrogen and stored at $-80^{\circ} \mathrm{C}$.

For each sample RNA was extracted from the frozen filter with acidic phenol (Weinbauer et al., 2002) and quantified using a NanoDrop ND-1000 spectrometer (NanoDrop Technologies). To generate $p m o A$-specific cDNA, 100 ng RNA was reverse transcribed using the iScript Select cDNA Synthesis Kit (Biorad) and reverse primer mb661r (Costello and Lidstrom, 1999). To detect potential DNA contamination one sample was incubated without reverse transcriptase. $1 \mu \mathrm{L}$ of cDNA was amplified by Polymerase Chain Reaction (PCR). For the generation of specific GC-clamped PCR products a discontinuous PCR was applied: reactions (50 $\mu \mathrm{L}$ ) containing $1 \times$ PCR buffer, $200 \mu \mathrm{M}$ of each dNTP, $0.3 \mu \mathrm{M}$ reverse primer mb661 $\mathrm{r}$, $0.1 \mu \mathrm{M}$ forward primer A189f (Holmes et al., 1995), $0.5 \mathrm{mM} \mathrm{MgCl}_{2}, 0.5 \mu \mathrm{L}$ polymerase (Herculase II, Fusion) and template cDNA were incubated at initial $94{ }^{\circ} \mathrm{C}$ for $5 \mathrm{~min}$. 
After 20 cycles of $60 \mathrm{~s}$ at $94^{\circ} \mathrm{C}, 60 \mathrm{~s}$ at $56^{\circ} \mathrm{C}$ and $30 \mathrm{~s}$ at $72{ }^{\circ} \mathrm{C}$, the PCR was paused at $72{ }^{\circ} \mathrm{C}$ and $0.12 \mu \mathrm{M}$ A189f GC primer were added to each reaction. Afterwards the PCR was resumed for another 15 cycles with conditions as described above, followed by a final elongation step of $5 \mathrm{~min}$ at $72{ }^{\circ} \mathrm{C}$. Specificity of the PCR products was documented by agarose gel electrophoresis and staining with ethidium bromide. The described discontinuous PCR yielded more specific and distinct PCR products than a conventional PCR with GC-primer (data not shown).

PCR products were separated by Denaturing Gradient Gel Electrophoresis (DGGE) using a gradient of $35 \%$ to $80 \%$ denaturant in a $6 \%$ polyacrylamide gel. Electrophoresis ran at $100 \mathrm{~V}$ and $60^{\circ} \mathrm{C}$ for $16 \mathrm{~h}$ in $1 \times \mathrm{TAE}$ buffer. The gel was stained with a $1: 5000$ dilution of SYBRGold (Invitrogen) for $30 \mathrm{~min}$. All bands from each depth were excised and reamplified in a PCR reaction containing $1 \times$ PCR buffer, 0.3 $\mu \mathrm{M}$ of A189f and mb661r each, $200 \mu \mathrm{M}$ of each dNTP and $0.5 \mu \mathrm{L}$ polymerase in 30 cycles with an annealing temperature of $56{ }^{\circ} \mathrm{C}$. PCR products were purified with NucleoSpin purification kit (Macherey-Nagel) and sequenced with primers A189f and mb661r by AGOWA (Berlin, Germany). Forward and reverse sequences were checked for quality applying Seqman software (DNASTAR).

For phylogenetic analysis the ARB software package was used (Ludwig et al., 2004). Alignment was based on partial DNA sequences of $p m o A$ and $a m o A$ genes obtained from GenBank Database with partial sequences of amoA (Accession numbers: AF037107, AF043710, AF037108) serving as an outgroup in the tree construction. Sequences for analysis were reduced to unambiguously alignable positions.

Three different trees were calculated using the algorithms maximum likelihood (PHYML), maximum parsimony and neighbour-joining with Jukes-Cantor correction. Nucleotide sequence accession numbers are deposited in the GenBank database (accession number KC188735).

\subsubsection{Lipid biomarkers}

For lipid biomarker studies a sample was selected from the centre of the redox-zone at $100 \mathrm{~m}$ water depth. That depth was chosen to obtain a POM sample that reflects the in situ microbial turnover of methane under low-oxygen conditions and is not "contaminated" by external water masses (i.e. increased oxygen concentrations or anoxic conditions) which may also include other methane consuming 
microorganisms (e.g. consortia performing the anaerobic oxidation of methane). 214 $\mathrm{L}$ of water were filtered on glass microfiber filters $(\varnothing 30 \mathrm{~cm} ; 0.7 \mu \mathrm{m}$ pore size) over a time span of two hours using a PUMP-CTD system (Strady et al., 2008). Half of the filter was extracted in triplicate with dichloromethane and methanol $(3: 1, \mathrm{v}: \mathrm{v})$ in a CEM Mars 5 microwave (Matthews, NC) at $80^{\circ} \mathrm{C}$ and $800 \mathrm{~W}$. An aliquot of the sample was acetylated with acetic acid/pyridine as described elsewhere (Blumenberg et al., 2007) and analyzed using high performance liquid chromatography-mass spectrometry (LC-MS). LC-MS was performed using a Varian Prostar Dynamax HPLC system coupled to a Varian $1200 \mathrm{~L}$ triple quadrupole mass spectrometer (for analytical details see Blumenberg et al., 2010). Another aliquot of the extract was separated by column chromatography into a hydrocarbon (F1), an alcohol and ketone (F2), and a polar fraction (F3) using a column (Ø $1 \mathrm{~cm}$ ) filled with $7.5 \mathrm{~g}$ silica gel 60 (according to Blumenberg et al., 2010). (F3) was transmethylated using trimethylchlorosilane in methanol $\left(1: 8 ; \mathrm{v}: \mathrm{v} ; 1.5 \mathrm{~h}\right.$ at $\left.80^{\circ} \mathrm{C}\right)$. Double bond positions within unsaturated fatty acid methyl esters were determined by derivatisation with dimethyldisulfide (DMDS; method modified after Carlson et al., 1989 and Gatellier et al., 1993). The polar fraction (F3), and the DMDS derivatized sample were analysed with coupled gas chromatography-mass spectrometry (GC-MS) using a Varian CP3800 gas chromatograph equipped with a fused silica column (Phenomenex Zebron ZB-5MS, 30 m, I.D. $0.32 \mathrm{~mm}$ ) coupled to a Varian 1200L mass spectrometer. He was used as carrier gas. The temperature program was $80^{\circ} \mathrm{C}(3 \mathrm{~min})$ to $310^{\circ} \mathrm{C}$ (held 25 $\min )$ at $4{ }^{\circ} \mathrm{C} \mathrm{min}^{-1}$. Compounds were identified by comparing mass spectra and retention times to published data. ${ }^{13} \mathrm{C}$ values of fatty acid methyl esters from the polar fraction (F3) were measured in replicate as described previously (Blumenberg et al., 2010). The precision was generally better than $0.5 \%$.

\subsection{Results and discussion}

\subsubsection{Physical parameters and gas chemistry}

The estuarine circulation in the Baltic Sea causes a strong vertical salinity gradient between the surface and deep water (Lass and Matthäus, 2008). This gradient is very pronounced in the deep basins of the central Baltic Sea (e.g. Gotland and Landsort Deep; Fig. 2) and reflects a water column stratification that limits the vertical mixing and water renewal in the deep strata (Reissmann et al., 2009). 

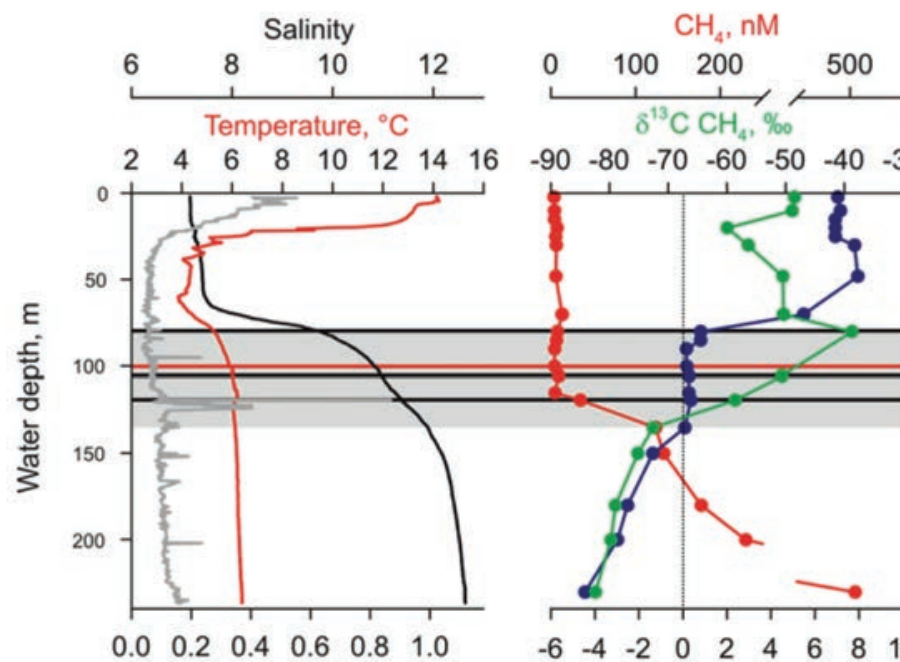

Turbidity

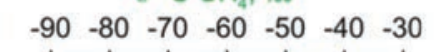

$\begin{array}{lllllll}-90 & -80 & -70 & -60 & -50 & -40 & -30\end{array}$
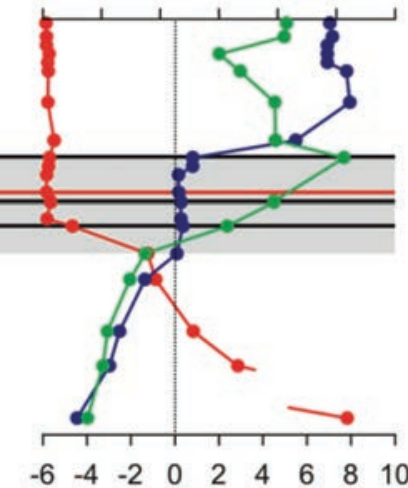

$\mathrm{O}_{2} / \mathrm{H}_{2} \mathrm{~S}, \mathrm{mLL}^{-1}$

Fig. 2: Left: vertical distribution of salinity (black), temperature (red), and turbidity (grey). Right: vertical distribution of oxygen and hydrogen sulfide (expressed as negative oxygen equivalents, blue), methane (red), and $\delta^{13} \mathrm{C}$ value of methane (green). The depth interval of the redox-zone is displayed in grey (oxygen concentration $0-0.8 \mathrm{~mL}$ $\mathrm{L}^{-1}$ ). The water depths for molecular biological and lipid biomarker studies are indicated with colored horizontal lines (black=molecular biology, red=molecular biology together with lipid biomarkers).

Oceanographic investigations, carried out at the redox-zone of the Gotland Deep, show that this depth is periodically perturbed by intrusions, internal waves or eddies which can shift the amplitudes of isoclines up to $10 \mathrm{~m}$ within time spans less than an hour (shown for temperature and salinity in Lass et al., 2003; Dellwig et al., 2012). During sampling, the specific water column structure led to oxygen

deficiency below a water depth of about $80 \mathrm{~m}$. Further downward, the oxygen concentrations decreased below $0.8 \mathrm{~mL} \mathrm{~L}^{-1}$, characterizing the redox-zone between the oxic surface and anoxic deep waters. The lower boundary of the redox-zone was located at about $138 \mathrm{~m}$ water depth where the concentration of hydrogen sulfide $\left(\mathrm{H}_{2} \mathrm{~S}\right)$ started to increase. A distinct turbidity anomaly was observed at about $120 \mathrm{~m}$ water depth (Fig. 2). This specific feature is known from other anoxic basins like the Black Sea and is most likely caused by the precipitation of iron and manganese oxides (Kempe et al., 1991) and an enrichment of particulate organic matter (POM) due to enhanced microbial activity (Prokhorenko et al., 1994). The concentrations of $\mathrm{H}_{2} \mathrm{~S}$ and other reduced chemical species like ammonium $\left(\mathrm{NH}_{4}{ }^{+}\right)$are constantly increasing with depth, indicating an upward flux from the sediment or deep water towards the redox-zone (Nausch et al., 2008). The same concentration pattern was observed for methane (Fig. 2). Highest methane concentrations were detected close to the seafloor (504 $\mathrm{nM}$ at $230 \mathrm{~m}$ water depth) supporting an origin from methanogenesis in the sediment (Piker et al., 1998). Indeed, low $\delta^{13} \mathrm{C} \mathrm{CH}_{4}$ values $(-82.4 \%$ to $-75.2 \%$, Fig. 2$)$ observed in the anoxic water body clearly point at a 
microbial methane source (Whiticar, 1999). The methane concentration profile shows a pronounced decrease within the redox-zone from $124 \mathrm{nM}$ at $135 \mathrm{~m}$ water depth to $4.8 \mathrm{nM}$ at $115 \mathrm{~m}$ water depth. At the same time, ${ }^{13} \mathrm{C}^{\mathrm{CH}_{4}}$ values substantially increase (up to $-38.7 \%$ at $80 \mathrm{~m}$ water depth). As microbial reactions favour the incorporation of ${ }^{12} \mathrm{C}$ and thus, enrichment in ${ }^{13} \mathrm{CH}_{4}$ in the residual methane pool, this isotopic shift clearly indicates microbial methane oxidation within that water level (Whiticar, 1999). In a first approximation the methane oxidation rate can be derived from the methane gradient and the vertical transport velocity. Using the vertical diffusivity (kz) of $0.95 \mathrm{~m}^{2} \mathrm{~d}^{-1}$ (Axell, 1998) in

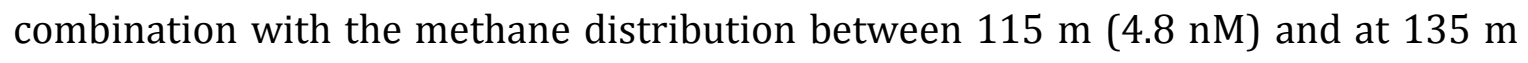
water depth (124 nM) this calculation leads to a flux of methane of $5.7 \mu \mathrm{mol} \mathrm{m}^{-2} \mathrm{~d}^{-1}$. If we assume that this flux is oxidized within the $20 \mathrm{~m}$ depth interval, we receive a methane consumption rate of $0.28 \mathrm{nM} \mathrm{d}^{-1}$. An inverse trend in methane carbon isotope ratios is observed above the suboxic layer (Fig. 2; $\delta^{13} \mathrm{C}$ ratios between $-59.9 \%$ and $-48.5 \%$ ). This trend is probably caused by (1) the downward ventilation ofatmospheric methane $(-47.4 \%$ \%; http://www.esrl.noaa.gov /gmd/ccgg/ iadv/), and/or (2) microbial methane production in shallow waters. The process of methane formation in an oxygenated water column has been observed in many regions (Holmes et al., 2000; Schmale et al., 2010a) and seems to be related to the decay of methylphosphonates, in particular under phosphatelimiting conditions, and/or methanogenesis in the anoxic interior of particles (Karl et al., 2008). Such methane forming processes are also indicated in our dataset by a pronounced ${ }^{13} \mathrm{CH}_{4}$ depletion at $20 \mathrm{~m}$ water depth $\left(\delta^{13} \mathrm{C}=-59.9 \%\right.$ ) together with slightly elevated methane concentrations of $7 \mathrm{nM}$ (surrounding water depths around $4 \mathrm{nM}$ ). However, within the surface water, methane is only slightly enriched compared with the atmospheric equilibrium (144\% saturation ratio; Schmale et al., $2010 \mathrm{~b}$ ), indicating that the local emission of methane into the atmosphere is rather low.

\subsubsection{Methanotrophic microorganisms within the redox-zone}

Chemical gradients feature versatile environments and are known to harbour enhanced microbial abundance and activity. Within the redox-zone of the central Baltic Sea, various biogeochemical processes have been identified, such as 


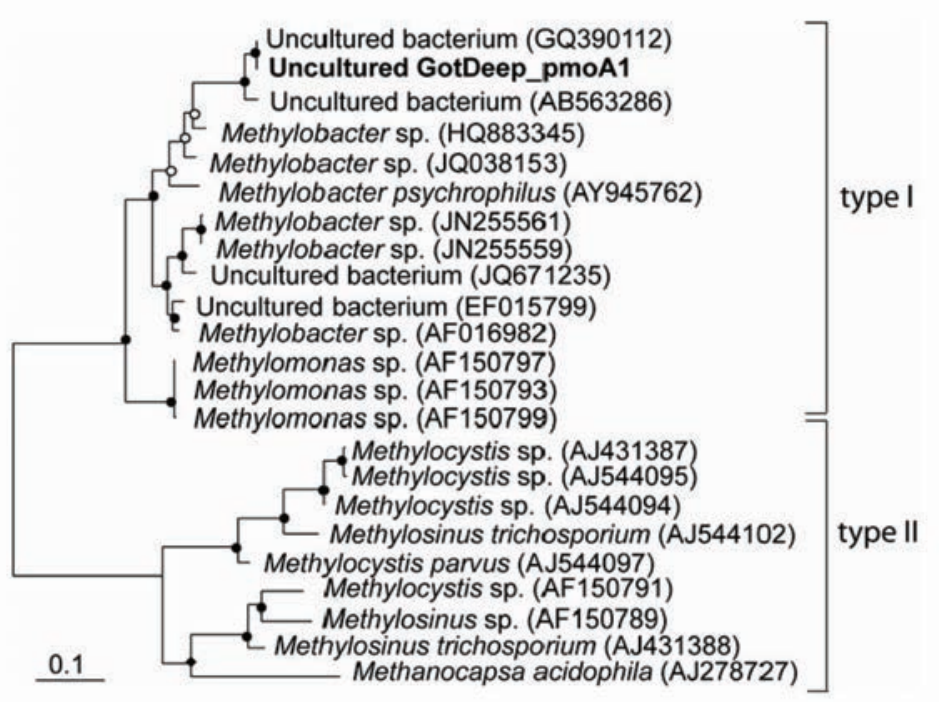

Fig. 3: Unrooted maximum likelihood tree showing the phylogenetic affiliation of the partial pmoA DNA sequence generated from the filter samples taken in 80,100, 105 and 119m water depth (marked bold). Black circles=validation of subtree by neighbourjoining and parsimony; white circles=validation of subtree by parsimony; black diamond=validation of subtree by neighbourjoining. Scale bar represents 10 substitutions per 100 nucleotides. For tree construction partial amoA sequences were used as an outgroup (not shown).

denitrification, ammonia oxidation, or dark $\mathrm{CO}_{2}$ fixation (Labrenz et al., 2005; Jost et al., 2008; Glaubitz et al., 2009; Labrenz et al., 2010) and also microbial consumption of methane was proposed as mechanism explaining the strong methane decrease in this water layer (Schmale et al., 2010a). To gain information on the contribution of methanotrophic microorganisms to the POM within the redox-zone, we performed expression analyses of the methane monooxygenase gene $(p m o A)$, and studied concentrations and distributions of bacteriohopanepolyols (BHPs). The presence of methanotrophic bacteria was proved by molecular biological studies carried out on samples obtained from 80, 100, 105 and $119 \mathrm{~m}$ water depth (Fig. 2). Although the two groups of methanotrophs, type I and type II, use different physiological pathways for the assimilation of carbon from methane, namely the ribulose monophosphate pathway and the serine pathway, the key enzyme methane monooxygenase responsible for the initial oxidation of methane to methanol is present in both groups. The gene coding for the alpha subunit of the particulate form of the enzyme $(p m o A)$ has been used as a marker for the detection and characterization of methanotrophic communities in different habitats (Costello and Lidstrom, 1999; Bourne et al., 2001; Chen et al., 2007; Chen et al., 2008). In order to identify active methanotrophs we investigated $p m o A$ gene expression in situ. Based on DGGE analysis only one type of pmoA transcript, named Uncultured GotDeep pmoA1, was present throughout the redox-zone. Phylogenetically it is affiliated with the type I methanotrophs and 


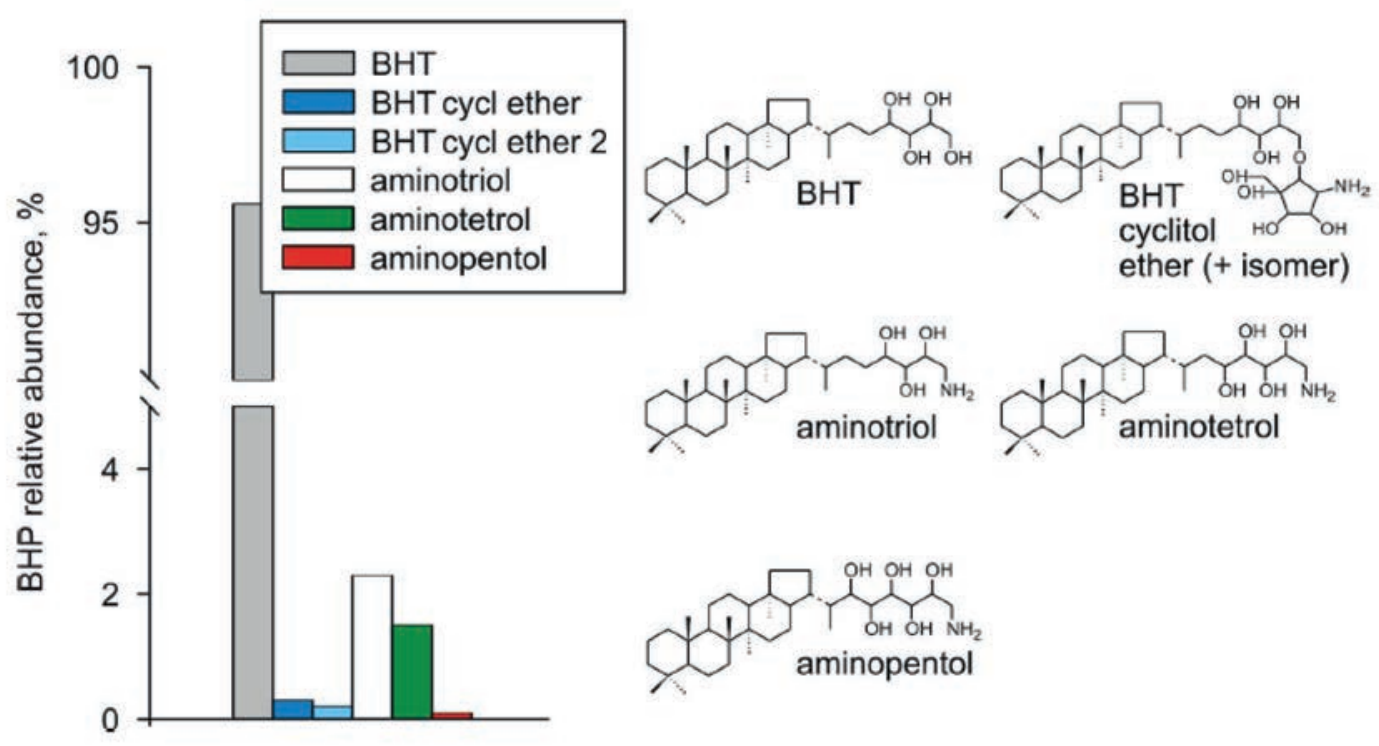

Fig. 4: The relative abundances of specific bacteriohopanepolyols (BHPs) sampled in $100 \mathrm{~m}$ water depth, together with the chemical structure of each compound. BHT=bacteriohopanetetrol; cycl=cyclitol.

practically identical to an uncultured bacterium found in the meromictic crater lake Lac Pavin (Fig. 3). With a permanently anoxic monimolimnion, also due to a halocline, elevated concentrations of $\mathrm{CH}_{4}$ and nearly identical temperatures around 5-6 ${ }^{\circ} \mathrm{C}$ (Aeschbach-Hertig et al., 2002) environmental conditions in Lac Pavin are in some aspects comparable to the central Baltic Sea (Fig. 2). Thus, activity of these identified methanotrophs could be indicative of this kind of habitat. To support these findings, an additional POM sample obtained in the centre of the redox-zone was investigated for lipid biomarkers. Of special biomarker value are BHPs with an A-ring methylation at C-3 (Neunlist and Rohmer, 1985) and/or an amino group at C35 of the hopanoid structure, both of which are widespread in methanotrophic bacteria (Neunlist and Rohmer, 1985; Talbot et al., 2001). The vast majority of BHPs was composed of bacteriohopane-32,33,34,35-tetrol (BHT) and 35aminobacteriohopane-32,33,34-triol (aminotriol), the most common and thus unspecific BHPs (Fig. 4). C-3 methylated BHPs were not observed. However, low abundances of 35-aminobacteriohopane-31,32,33,34-tetrol (aminotetrol) and of 35aminobacteriohopane-30,31,32,33,34-pentol (aminopentol) were found (Fig. 4). Whereas both these amino-BHPs are considered indicative of methanotrophic bacteria (Neunlist and Rohmer, 1985; Talbot and Farrimond, 2007), particularly the 


\begin{tabular}{|c|c|c|c|}
\hline Fatty acid & $\begin{array}{c}\text { Concentration } \\
{\left[\mu \mathrm{g} \mathrm{g}^{-1} \mathrm{C}_{\mathrm{org}}\right]}\end{array}$ & $\begin{array}{l}\% \text { of total } \\
\text { fatty acids }\end{array}$ & $\begin{array}{l}\delta^{13} \mathrm{C} \\
{[\% \circ]}\end{array}$ \\
\hline $\mathrm{C} 14: 0$ & 37.7 & 0.7 & -26.9 \\
\hline iC15:0 & 86.1 & 1.6 & -21.5 \\
\hline aiC15:0 & 101.4 & 1.9 & -26.2 \\
\hline C15:0 & 86 & 1.6 & -25.8 \\
\hline iC16:0 & 29.4 & 0.5 & -29.7 \\
\hline$C 16: 1 \omega 9 t$ & 31.4 & 0.6 & -22.2 \\
\hline C16:1w8c & 9.8 & 0.2 & -38.8 \\
\hline $\mathrm{C} 16: 1 \omega 8 \mathrm{t}$ & 33.0 & 0.6 & -30.4 \\
\hline$C 16: 1 \omega 7 c$ & 231.0 & 4.2 & -27.6 \\
\hline$C 16: 1 \omega 7 t$ & 57.0 & 1.0 & - \\
\hline$C 16: 1 \omega 5 c$ & 66.1 & 1.2 & -35.7 \\
\hline $\mathrm{C} 16: 1 \omega 5 \mathrm{t}$ & 22.2 & 0.4 & -33.8 \\
\hline C16:0 & 1300.1 & 23.7 & -26.9 \\
\hline iC17:0 & 9.7 & 0.2 & -29.6 \\
\hline aiC17:0 & 16.3 & 0.3 & -28.6 \\
\hline C17:0 & 63.2 & 1.2 & -30.9 \\
\hline C18:2 & 41.4 & 0.8 & -25.4 \\
\hline C18:3 & 32.5 & 0.6 & - \\
\hline C18:1 w9c & 246.4 & 4.5 & -26.5 \\
\hline $\mathrm{C} 18: 1 \omega 7 c$ & 232.6 & 4.2 & -24.9 \\
\hline $\mathrm{C} 18: 1 \omega 6 c$ & 15.0 & 0.3 & -30.9 \\
\hline $\mathrm{C} 18: 1 \omega 5 c$ & 9.0 & 0.2 & -20.2 \\
\hline C18:0 & 2279.4 & 41.6 & -27.1 \\
\hline iC19:0 & 49.7 & 0.9 & -26.5 \\
\hline C19:0 & 47.5 & 0.9 & - \\
\hline C20:0 & 154.0 & 2.8 & -29.6 \\
\hline C21:0 & 20.1 & 0.4 & - \\
\hline $\mathrm{C} 22: 0$ & 102.7 & 1.9 & -29.7 \\
\hline C24:0 & 77.2 & 1.4 & - \\
\hline
\end{tabular}

Table 1: Concentrations, relative abundances and $\delta^{13} \mathrm{C}$ values of individual fatty acids (analyzed as methyl ester derivatives) at $100 \mathrm{~m}$ water depth of the Gotland Deep. Fatty acids specific for methanotrophoc bacteria are given in bold letters.

latter is even regarded as a biomarker for the type I subgroup (gamma proteobacteria; Talbot and Farrimond, 2007). Further evidence for a prominent contribution of type I methanotrophs comes from the

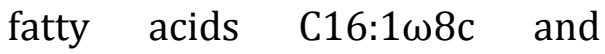
C16:1 $\omega 5 \mathrm{c}$ which are considered as specific to this group (Makula, 1978; Nichols et al., 1985; Table 1). At the same time the lack of

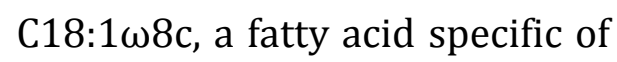
type II methanotrophs (alpha proteobacteria, Bowmann et al., 1991), indicates that these microorganisms do not play a significant role for the methane turnover at the redox-zone of the Gotland Deep. Biomarkers from methanotrophic bacteria commonly show the isotopic traits of the substrate (Summons et al., 1994). Indeed the $\delta^{13} \mathrm{C}$ values of the fatty acids $\mathrm{C} 16: 1 \omega 8 \mathrm{c}$ and $\mathrm{C} 16: 1 \omega 5 \mathrm{c}(-38.8 \% \mathrm{o}$ and $-35.5 \%$, respectively; Table 1) are well within the $\delta^{13} \mathrm{C} \mathrm{CH}_{4}$ at 80 and $105 \mathrm{~m}(=-38.7 \%$ and $-50.6 \%$, respectively; Fig. 2). Whereas biomarker indications for the presence of methanotrophic bacteria exist, their relative abundance among the bacterial community appears to be low. This is indicated (i) by the low proportion of methanotroph-specificamino-BHPs within the total BHPs $(<1.6 \%$ of total BHPs; note that amino-BHPs are often predominant in methanotrophs; Talbot et al., 2001), and

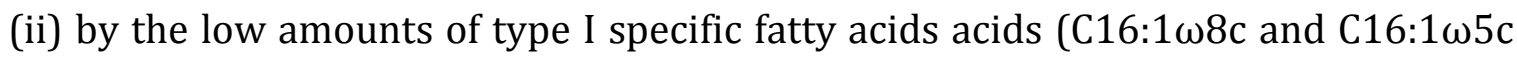


represent $1.4 \%$ of total fatty acids). Thus, in contrast to studies in the redox-zone of the Black Sea, where indications for type I, II and X were found (Gal'chenko et al., 1988; Durisch-Kaiser et al., 2005; Blumenberg et al., 2007), the diversity of active aerobic methanotrophs in the redox-zone of the Gotland Deep seemed to be restricted. These findings are only based on one dataset, but it would be in line with previous studies investigating the microbial catalysts of denitrification, nitrification, or dark $\mathrm{CO}_{2}$ fixation in central Baltic Sea redox-zones which also revealed that these pathways were actively driven by only a few bacterial or archaeal key species (Grote et al., 2008; Glaubitz et al., 2009; Labrenz et al., 2010). An explanation for the reduced diversity of active microorganisms along the central Baltic Sea redox-zone could be the periodic perturbation of the stratification which does not occur in the same strength and frequency in the Black Sea. An overlap of sulfide- and oxygencontaining waters can occur in the Gotland Basin (Axell, 1998), and it is known that sulfide is toxic for many organisms or at least can inhibit the activity of specific microorganisms (Erguder et al., 2009). Thus, potential sulfide stress could inhibit other than type I methanotrophic bacteria within the redox-zone of the Gotland Deep, but this interesting aspect needs further investigation.

\subsection{Conclusions}

Using a multidisciplinary approach of gas chemistry, molecular biology, and lipid geochemistry, we identified the process of aerobic methane oxidation within the pelagic redox-zone of the Gotland Deep (central Baltic Sea). This was evidenced by a strong decrease in methane concentrations together with a ${ }^{13} \mathrm{C} \mathrm{CH}_{4}$ enrichment, the detection of the key enzyme methane monooxygenase $(\mathrm{pmoA})$, and the occurrence of lipids specific for methanotrophic bacteria (e.g., aminopentol; 16:1 $\omega 8 \mathrm{c}$ fatty acid). Phylogenetic and biomarker data indicate that the diversity of active aerobic methanotrophs in the redox-zone of the Gotland Deep was restricted to members of the type I subgroup. In contrast to other marine settings with a permanent stratification, e.g. the Black Sea, the physical and biogeochemical structure of the Gotland Deep is periodically disturbed by intrusions, eddies, internal waves or longterm vertical transport mechanisms. How this variable environment is affecting the methane turnover in the water column and the microbial community responsible for this process is an interesting question that needs to be investigated in future studies. 
Also the transferability of our results on a basin scale needs to be addressed as some parts of the basin (e.g. the basin boundaries) are permanently influenced by intrusions and elevated vertical mixing that might influence the processes involved in the turnover of methane.

\section{Acknowledgments}

We thank the captain, officers and crew aboard R/V Maria S. Merian (MSM 08/3) for their assistance on sea. We gratefully acknowledge the efforts of G. Nausch and S. Krüger in carrying out the oxygen and hydrogen sulfide analysis as well as the CTD work on the cruise. We also thank J. Dyckmans (Centre for Stable Isotope Research and Analysis, University of Göttingen) for help with compound specific carbon isotope analysis and T. Licha and K. Nödler for support with LC-MS analyses. We thank Marcus Elvert and an unknown reviewer for their thoughtful reviews and comments. The study was supported by the Deutsche Forschungsgemeinschaft (DFG) through grants SCHM 2530/2-1, BL 971/3-1, and BL 971/1-3.

\section{References}

Aeschbach-Hertig, W., Hofer, M., Schmid, M., Kipfer, R., Imboden, D. M., 2002. The physical structure and dynamics of a deep, meromictic crater lake (Lac Pavin, France). Hydrobiologia 487, 111-136.

Axell, L. B., 1998. On the variability of Baltic Sea deepwater mixing. Journal of Geophysical Research: Oceans 103, 21667-21682.

Bange, H.W., Bartell, U. H., Rapsomanikis, S., Andreae, M. O., 1994. Methane in the Baltic and Noth Seas and a reassessment of the marine emission of methane. Global Biogeochemical Cycles 8, 465- 480.

Barnes, R. O. and Goldberg, E. D., 1976. Methane production and consumption in anaerobic marine sediments. Geology, 4, 297-300.

Beal, E. J., House, C. H., Orphan, V. J., 2009. Manganese- and iron-dependent marine methane oxidation. Science 325, 184-187. 
Blumenberg, M., Seifert, R., Michaelis, W., 2007. Aerobic methanotrophy in the oxicanoxic transition zone of the Black Sea water column. Organic Geochemistry 38, 8491.

Blumenberg, M., Mollenhauer, G., Zabel, M., Reimer, A., Thiel, V., 2010. Decoupling of bio- and geohopanoids in sediments of the Benguela Upwelling System (BUS). Organic Geochemistry 41, 1119-1129.

Bourne, D. G., McDonald, I. R., Murrell, J. C., 2001. Comparison of $p m o A$ PCR primer sets as tools for investigating methanotroph diversity in three Danish soils, Applied and Environmental Microbiology 67, 3802-3809.

Bowmann, J. P., Skerratt, J. H., Nichols, P. D., Sly, L. I., 1991. Phospholipid fatty acid and lipopolysaccharide fatty acid signature lipids in methane-utilizing bacteria. FEMS Microbiology Ecology 85, 15-22.

Carlson, D. A., Roan, C. S., Yost, R. A., Hector, J., 1989. Dimethyl disulfide derivatives of long chain alkenes, alkadienes, and alkatrienes for gas chromatography/mass spectrometry. Analytical Chemistry 61, 1564-1571.

Chen, Y., Dumont, M. G., Cébron, A., Murrell, J. C., 2007. Identification of active methanotrophs in a landfill cover soil through detection of expression of 16S rRNA and functional genes. Environmental Microbiology 9, 2855-2869.

Chen, Y., Dumont, M. G., McNamara, N. P., Chamberlain, P. M., Bodrossy, L., StralisPavese, N., Murrell, J. C., 2008. Diversity of the active methanotrophic community in acidic peatlands as assessed by mRNA and SIP-PLFA analyses. Environmental Microbiology 10, 446-459.

Costello, A. M. and Lidstrom, M. E., 1999. Molecular characterization of fuctional and phylogenetic genes from natural populations of methanotrophs in lake sediments. Applied and Environmental Microbiology 65, 5066-5074.

Dando, P. R., O’Hara, S. C. M., Schuster, U., Taylor, L. J., Clayton, C. J., Baylis, S., Laier, T., 1994. Gas seepage from a carbonate-cemented sandstone reef on the Kattegat coast of Denmark, Marine and Petroleum Geology 11, 182-189. 
Dellwig, O., Schnetger, B., Brumsack, H.-J., Grossart, H.-P., Umlauf, L., 2012. Dissolved reactive manganese at pelagic redoxclines (part II): Hydrodynamic conditions for accumulation. Journal of Marine Systems 90, 31-41.

Durisch-Kaiser, E., Klauser, L., Wehrli, B., Schubert, C., 2005. Evidence of intense archaeal and bacterial methanotrophic activity in the Black Sea water column. Applied and Environmental Microbiology 71, 8099-8106.

Erguder, T. H., Boon, N., Wittebolle, L., Marzorati, M., Verstraete, W., 2009. Environmental factors shaping the ecological niches of ammonia-oxidizing archaea. FEMS Microbiology Reviews 33, 855- 869.

Ettwig, K. F., Butler, M. K., Le Paslier, D., Pelletier, E., Mangenot, S., Kuypers, M. M. M., Schreiber, F., Dutilh, B. E., Zedelius, J., de Beer, D., Gloerich, J., Wessels, H. J. C. T., van Alen, T., Luesken, F., Wu, M. L., van de Pas-Schoonen, K. T., Op den Camp, H. J. M., Janssen-Megens, E. M., Francoijs, K.-J., Stunnenberg, H., Weissenbach, J., Jetten, M. S. M., Strous, M., 2010. Nitrite-driven anaerobic methane oxidation by oxygenic bacteria. Nature 464, 543-548.

Gal'chenko, V. F., Abranochkina, F. N., Bezukova, L. V., Sokolova, E. N., Ivanov, M. V., 1988. Species composition of the aerobic methanotrophic microflora of the Black Sea. Microbiology 57, 305-311.

Gatellier, J.-P. L. A., de Leeuw, J. W., Sinninghe Damst'e, J. S., Derenne, S., Largeau, C., Metzger, P., 1993. A comparative study of macromolecular substances of a Coorongite and cell walls of the extant alga Botryococcus braunii, Geochimica et Cosmochimica Acta 57, 2053-2068.

Glaubitz, S., Lueders, T., Abraham, W.-R., Jost, G., Jürgens, K., Labrenz, M., 2009. ${ }^{13}$ Cisotope analyses reveal that chemolithoautotrophic Gamma- and Epsilonproteobacteria feed a microbial food web in a pelagic redoxcline of the central Baltic Sea. Environmental Microbiology 11, 326-337.

Grasshoff, K., Erhardt, M., Kremling, K. (Eds), 1983. Methods of seawater analysis. Verlag Chemie, Weinheim, Germany. 
Grote, J., Jost, G., Labrenz, M., Herndl, G. J., Jürgens, K., 2008. Epsilonproteobacteria represent the major portion of chemoautotrophic bacteria in sulfidic waters of pelagic redoxclines of the Baltic and Black Seas, Applied and Environmental Microbiology 74, 7546- 7551.

Hinrichs, K. U. and Boetius, A., 2002. The anaerobic oxidation of methane: new insights in microbial ecology and biogeochemistry. In: Wefer, G., Billett, D., Hebbeln, D., Jørgensen, B. B., Schlüter, M., Van Weering, T. (Eds). Ocean Margin Systems. Springer Verlag, Berlin Heidelberg, 457-477.

Holmes, A. J., Costello, A., Lidstrom, M. E., Murrell, J. C., 1995. Evidence that participate methane monooxygenase and ammonia monooxygenase may be evolutionarily related. FEMS Microbiology Letters 132, 203-208.

Holmes, M. E., Sansone, F. J., Rust, T. M., Popp, B. N., 2000. Methane production, consumption, and air-sea exchange in the open ocean: an evaluation based on carbon isotopic ratios. Global Biogeochemical Cycles 14, 1-10.

Holtermann, P. L. and Umlauf, L., 2012. The Baltic Sea tracer release experiment: 2. Mixing processes, Journal of Geophysical Research 117, C01022.

Jost, G., Zubkov, M. V., Yakushev, E. V., Labrenz, M., Jürgens, K., 2008. High abundance and dark $\mathrm{CO} 2$ fixation of chemolithoautotrophic prokaryotes in anoxic waters of the Baltic Sea, Limnology and Oceanography 53, 14-22.

Karl, D. M., Beversdorf, L., Bjorkman, K. M., Church, M. J., Martinez, A., Delong, E. F., 2008. Aerobic production of methane in the sea, Nature Geoscience 1, 473-478.

Keir, R., Schmale, O., Seifert, R., Sültenfuß, J., 2009. Isotope fractionation and mixing in methane plumes from the Logatchev hydrothermal field, Geochemistry Geophysics Geosystems 10, Q05005.

Kempe, S., Diercks, A.-R., Liebezeit, G., Prange, A., 1991. Geochemical and structural aspects of the pycnocline in the Black Sea (R/V Knorr 134-8 Leg 1, 1988). In: Izdar, E. and Murray, J. W. (Eds). Black Sea Oceanography. NATO ASI Series C, Kluwer Academic Publisher, Dordrecht, 89-110. 
Kessler, J. D., Reeburgh, W. S., Southon, J., Seifert, R., Michaelis, W., Tyler, S. C., 2006. Basin-wide estimates of the input of methane from seeps and clathrates to the Black Sea. Earth and Planetary Science Letters 243, 366-375.

Labrenz, M., Jost, G., Pohl, C., Beckmann, S., Martens-Habenna, W., Jürgens, K., 2005. Impact of different in vitro electron donor/acceptor conditions on potential chemolithoautotrophic communities from marine pelagic redoxclines. Applied and Environmental Microbiology 71, 6664-6672.

Labrenz, M., Sintes, E., Toetzke, F., Zumsteg, A., Herndl, G. J., Seidler, M., Jürgens, K., 2010. Relevance of a crenarchaeotal subcluster related to Candidatus Nitrosopumilus maritimus to ammonia oxidation in the suboxic zone of the central Baltic Sea. ISME 4, 1496-1508.

Lass, H. U. and Matthäus, W., 2008. General oceanography of the Baltic Sea. In: Feistel, R., Nausch, G., and Wasmund, N. (Eds). State and evolution of the Baltic Sea, 1952-2005. John Wiley \& Sons, Inc., New Jersey, 5-44.

Lass, H. U., Prandke, H., Liljebladh, B., 2003. Dissipation in the Baltic proper during winter stratification. Journal of Geophysical Research 108, 3187.

Ludwig, W., Strunk, O., Westram, R., Richter, L., Meier, H., Yadhukumar, Buchner, A., Lai, T., Steppi, S., Jobb, G., Forster, W., Brettske, I., Gerber, S., Ginhart, A. W., Gross, O., Grumann, S., Hermann, S., Jost, R., Konig, A., Liss, T., Lussmann, R., May, M., Nonhoff, B., Reichel, B., Strehlow, R., Stamatakis, A., Stuckmann, N., Vilbig, A., Lenke, M., Ludwig, T., Bode, A., Schleifer, K.-H., 2004. ARB: a software environment for sequence data. Nucleic Acids Research 32, 1363-1371.

Makula, R. A., 1978. Phospholipid composition of methane-utilizing bacteria. Journal of Bacteriology 134, 771-777.

Matthäus, W., Nehring, D., Feistel, R., Nausch, G., Mohrholz, V., Lass, H. U., 2008. The inflow of high saline water into the Baltic Sea. In: Feistel, R., Nausch, G., and Wasmund, N. (Eds). State and evolution of the Baltic Sea, 1952-2005. John Wiley \& Sons, Inc., New Jersey, 265-310. 
Nausch, G., Nehring, D., Nagel, K., 2008. Nutrient concentrations, trends and their relation to eutrophication. In: Feistel, R., Nausch, G., and Wasmund, N. (Eds). State and evolution of the Baltic Sea, 1952-2005. John Wiley \& Sons, Inc., New Jersey, 337- 366.

Neunlist, S. and Rohmer, M., 1985. Novel hopanoids from the methylotrophic bacteria Methylococcus capsulatus and Methylomonas methanica. Biochemical Journal 231, 635-639.

Nichols, P. D., Shaw, P. M., Johns, R. B., 1985. Determination of the double bond position and geometry in monoenoic fatty acids from complex microbial and environmental samples by capillary GC-MS of their Diels-Alder adducts. Journal of Microbiological Methods 3, 311-319.

Piker, L., Schmaljohann, R., Imhoff, J. F., 1998. Dissimilatory sulfate reduction and methane production in Gotland Deep sediments (Baltic Sea) during a transition period from oxic to anoxic bottom water (1993-1996). Aquatic Microbial Ecology 14, 183-193.

Prokhorenko, Y. A., Krasheninnikov, B. N., Agafonov, E. A., Basharin, V. A., 1994. Experimental studies of the deep turbid layer in the Black Sea. Physical Oceanography 5, 133-139.

Reeburgh, W. S., 1976. Methane consumption in Cariaco Trench waters and sediments. Earth and Planetary Science Letters 28, 337-344.

Reeburgh, W. S., 2007. Ocean methane biogeochemistry. Chemical Reviews 107, 486-513.

Reissmann, J. H., Burchard, H., Feistel, R., Hagen, E., Lass, H. U., Mohrholz, V., Nausch, G., Umlauf, L., Wieczorek, G., 2009. Vertical mixing in the Baltic Sea and consequences for eutrophication - A review. Progress in Oceanography 82, 47-80.

Schmale, O., Beaubien, S. E., Rehder, G., Greinert, J., Lombardi, S., 2010a. Gas seepage in the Dnepr paleo-delta area (NW-Black Sea) and its regional impact on the water column methane cycle. Journal of Marine Systems 80, 90-100. 
Schmale, O., Schneider von Deimling, J., Gülzow, W., Nausch, G., Waniek, J. J., Rehder, G., 2010b. Distribution of methane in the water column of the Baltic Sea. Geophysical Research Letters 37, L12604.

Schmale, O., Haeckel, M., McGinnis, D. F., 2011. Response of the Black Sea methane budget to massive short-term submarine inputs of methane. Biogeosciences 8, 911918.

Schouten, S., Wakeham, S. G., Sinninghe Damsté, J. S., 2001. Evidence for anaerobic methane oxidation by archaea in euxinic waters of the Black Sea. Organic Geochemistry 32, 1277-1281.

Schubert, C. J., Coolen, M. J. L., Neretin, L. N., Schippers, A., Abbas, B., Durisch-Kaiser, E., Wehrli, B., Hopmans, E. C., Sinninghe Damsté, J. S., Wakeham, S., Kuypers, M. M. M., 2006. Aerobic and anaerobic methanotrophs in the Black Sea water column. Environmental Microbiology 8, 1844-1856.

Scranton, M. I., Crill, P., Angelis, M., Donaghay, P., Sieburth, J., 1993. The importance of episodic events in controlling the flux of methane from an anoxic basin. Global Biogiochemical Cycles 7, 491- 507.

Strady, E., Pohl, C., Yakushev, E. V., Krüger, S., Hennings, U., 2008. PUMP-CTD-System for trace metal sampling with a high vertical resolution. A test in the Gotland Basin, Baltic Sea. Chemosphere 70, 1309-1319.

Summons, R. E., Jahnke, L. L., Roksandic, Z., 1994. Carbon isotopic fractionation in lipids from methanotrophic bacteria: Relevance for interpretation of the geochemical record of biomarkers. Geochimica et Cosmochimica Acta 58, 28532863.

Talbot, H. M. and Farrimond, P., 2007. Bacterial populations recorded in diverse sedimentary biohopanoid distributions. Organic Geochemistry 38, 1212-1225.

Talbot, M., Watson, D. F., Murrell, J. C., Carter, J. F., Farrimond, P., 2001. Analysis of intact bacteriohopanepolyols from methanotrophic bacteria by reversed-phase highperformance liquid chromatography-atmopheric pressure chemical ionisation mass spectrometry. Journal of Chromatography A 921, 175-185. 
Thießen, O., Schmidt, M., Theilen, F., Schmitt, M., Klein, G., 2006. Methane formation and distribution of acoustic turbidity in organic-rich surface sediments in the Arkona Basin, Baltic Sea. Continental Shelf Research 26, 2469-2483.

Wakeham, S. G., Amann, R., Freeman, K. H., Hopmans, E. C., Joergensen, B. B., Putnam, I. F., Schouten, S., Damste, J. S. S., Talbot, M., Woebken, D., 2007. Microbial ecology of the stratified water column of the Black Sea as revealed by a comprehensive biomarker study. Organic Geochemistry 38, 2070-2097.

Weinbauer, M. G., Fritz, I., Wenderoth, D. F., Höfle, M. G., 2002. Simultaneous extraction from bacterioplankton of total RNA and DNA suitable for quantitative structure and functional analyses. Applied and Environmental Micobiology 68, 1082-1084.

Whiticar, M. J., 1999. Carbon and hydrogen isotope systematics of bacterial formation and oxidation of methane. Chemical Geology 161, 291- 314. 


\title{
5
}

\section{Biomarkers for aerobic methanotrophy in the water column of the stratified Gotland Deep}

\author{
Christine Berndmeyer, Volker Thiel, Oliver Schmale, and Martin Blumenberg \\ Organic Geochemistry (2013) 55, 103-111. \\ DOI: 10.1016/j.orggeochem.2012.11.010; reprinted with permission of Elsevier
}

\subsection{Abstract}

Filter samples from the oxic zone and suboxic zone of the physically stratified water column and sediment samples of the Gotland Deep, Baltic Sea, were analyzed for bacteriohopanepolyol (BHP) and phospholipid fatty acid (PLFA) concentrations. In total, eight BHPs were identified, with the greatest diversity in the suboxic zone. There, 35-aminobacteriohopane-31,32,33,34-tetrol (aminotetrol) and 35-aminobacteriohopane-30,31,32,33,34-pentol (aminopentol), whose concentrations decreased concurrently from the lower to the upper suboxic zone, indicated type I methanotrophic bacteria and thus aerobic oxidation of methane. The presence and activity of type I aerobic methanotrophic bacteria was further supported by the presence of ${ }^{13} \mathrm{C}$-depleted PLFAs, specifically 16:1 $1 \omega 8 \mathrm{c}$ and $16: 1 \omega 5 \mathrm{c}$ $\left(\delta^{13} \mathrm{C}\right.$ as low as $\left.-41.2 \%\right)$. However, the relative amount of methanotroph-specific compounds was low (aminopentol, $<0.2 \%$ of total BHPs; $16: 1 \omega 8 \mathrm{c}, \mathrm{ca}$. $0.5 \%$ of total PLFAs), suggesting a minor contribution of aerobic methanotrophic bacteria to the particulate organic matter. The distinctive BHP pattern in the suboxic zone, including aerobic methanotroph biomarkers and a tentative marker for a pelagic redoxcline [putative $22 S$ isomer of the ubiquitous $22 R$-bacteriohopanetetrol (BHT)], was mirrored in the sediment samples. Our data indicate that a major portion of the sedimentary hopanoids of the Gotland Deep is sourced from the suboxic part of the water column via an effective but unknown transport mechanism. 


\subsection{Introduction}

Microbial methane consumption (methanotrophy) is crucial for the removal of methane from marine sediments before it reaches the atmosphere (Reeburgh, 1976, 2007; Wakeham et al., 2004). Methane can be effectively oxidized by microorganisms in the sediment and water column, using a number of different electron acceptors (Beal et al., 2009; Ettwig et al., 2010), with the sulfate dependent anaerobic oxidation of methane as the quantitatively most important process (Barnes and Goldberg, 1976; Reeburgh, 2007 and references therein). As a consequence, only a low amount of methane is released to the atmosphere, where it is a highly effective greenhouse gas (IPCC, 2007). Of special importance for its production and methanotrophy in the ocean are stagnant anoxic basins, such as the Cariaco Basin and the Black Sea (Reeburgh, 1976, 2007; Scranton et al., 1993; Wakeham et al., 2004). Little is known about methane consumption in oceanic water columns, but studies have indicated that microbial oxidation of methane occurs particularly in the suboxic zone, a part of the redoxcline, as shown for the Black Sea (Durisch-Kaiser et al., 2005; Schubert et al., 2006; Blumenberg et al., 2007; Wakeham et al., 2007). The redoxcline, the transition zone between the oxic and

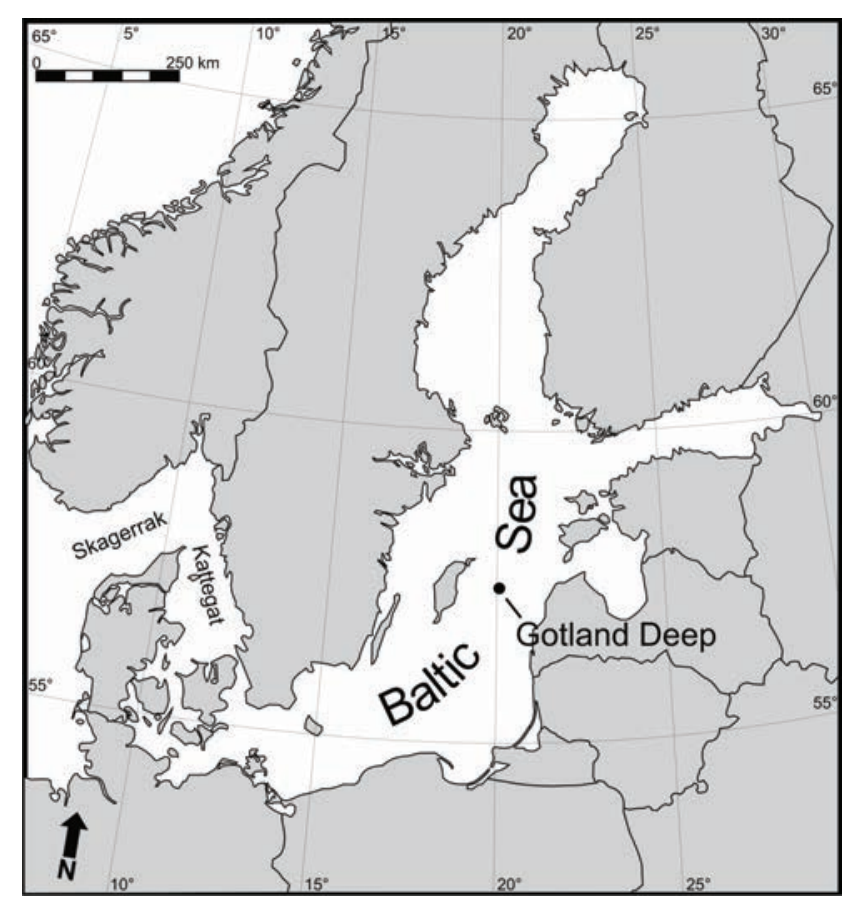

Fig. 1: Sample location in the Gotland Deep, East Gotland Basin. anoxic layers, is an important element, as it acts as a relatively stable region for several biogeochemical transformations (Schubert et al., 2006). Like the Black Sea and the Cariaco Basin, the central Baltic Sea is characterized by a stratified water column as a result of freshwater supply from rivers and salt water from the North Sea. It is a semi-enclosed marginal sea composed of a succession of basins divided by sills (Matthäus and Schinke, 1999; Lass and Matthäus, 2008). A connection 
to the North Sea exists via the Skagerrak/Kattegat strait (Fig. 1). According to its density, the inflowing saline North Sea water spreads in intermediate to deep Baltic Sea water layers and along the bottom, where the sills hamper its progress into the more distant basins (Reissmann et al., 2009). The frequent but small horizontal inflows from the North Sea have only little impact on the deep water of the more distant basins like the East-Gotland Basin and the Gotland Deep (249 m; Fig. 1) of the central Baltic. Only the rare, so-called major baltic inflows are able to carry large amounts of oxygenated saline water dense enough to renew the deep water of these basins (Matthäus and Schinke, 1999; Meier et al., 2006). The abundance of these inflows has, however, significantly decreased since the 1970s (Meier et al., 2006) and the last major inflows occurred in 1993 and 2003. Hence, the deeper central Baltic basins are characterized by longer stagnation phases of the deep water, leading to high concentrations of methane and S2- (Meier et al., 2006; Schmale et al., 2010). The physically different upper and lower water masses inhibit vertical mixing and lead to the stratified water column, where relatively stable physico- and biogeochemical zones become established, namely the upper oxic zone, the lower anoxic zone, with the suboxic zone in between. The latter in particular is a highly productive layer with a rapid turnover of organic material and a high abundance of microorganisms (Detmer et al., 1993). Anoxic bottom water conditions are also reflected in the upper laminated sediments of the Gotland Deep and their increasing organic carbon content, which is related to increasing primary production because of eutrophication and prolonged phases of $\mathrm{O}_{2}$ deficiency (Andrén et al., 2000; Harff et al., 2001).

A recent multidisciplinary study by our group reported initial biomarker, gas geochemical and microbiological indications for the occurrence of type I methanotrophic bacteria in a water sample from $100 \mathrm{~m}$, i.e. within the suboxic zone (Schmale et al., 2012). For a detailed view of the aerobic methanotrophic processes we have now quantitatively studied biomarkers, including phospholipid fatty acids (PLFAs) and bacteriohopanepolyols (BHPs; for structures, see Fig. 2) along a profile of several sampling depths within the oxic and suboxic zones. PLFAs occur in the membranes of all living cells, but not in storage lipids, and are rapidly turned over in dead cells (Fang et al., 2000). Some can be highly specific for certain source organisms, such as sulfate reducing bacteria (e.g. Taylor and Parkes, 1983) or 


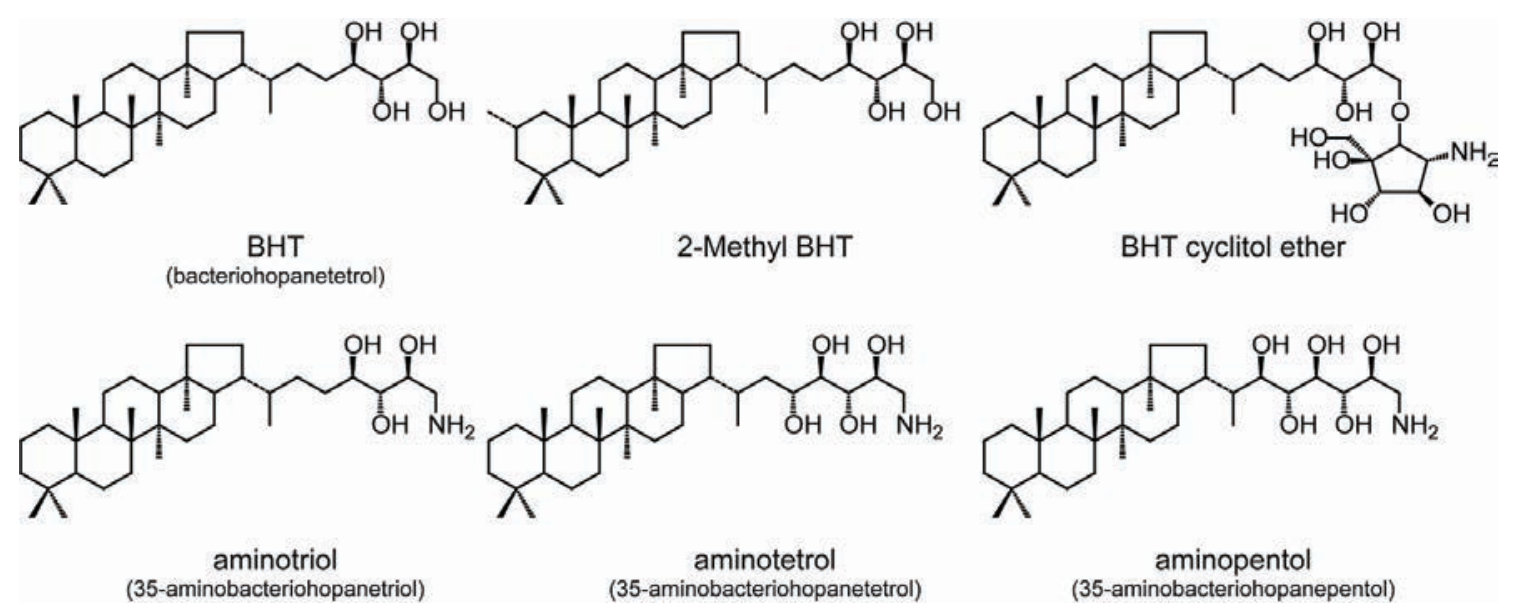

Fig. 2: BHP structures (the isomerism of BHT II and BHT cyclitol ether II was not characterized.

aerobic methanotrophic bacteria (e.g. Bowman et al., 1991; Bodelier et al., 2009). Like the PLFAs, some BHPs are rather widespread among bacteria, such as $22 R$ $17 \beta, 21 \beta$-bacteriohopane-32,33,34,35-tetrol (BHT). Others were found to be less abundant, such as 35-aminobacteriohopane-31,32,33,34-tetrol (aminotetrol) and 35-aminobacteriohopane-30,31,32,33,34-pentol (aminopentol), each with and without C-3 methylation that are indicative for aerobic methanotrophic bacteria (Talbot et al., 2008).

Here, we have used PLFAs and BHPs to identify the key methane oxidizing microorganisms. At the same time, we aimed at recognizing individual BHPs that may specify the particular oceanographic situation of the Gotland Deep as a stratified basin. Last, but not least, we studied the underlying surface deposits to test the potential of BHPs to become incorporated into the sedimentary record and thus, their utility for reconstructing water column stratification and methanotrophy during the variable Holocene history of the Baltic Sea.

\subsection{Methods}

\subsubsection{Samples}

Filter samples were taken during cruise MSM08-3 (station 271) of the RV Maria S. Merian in summer 2008. The sampling site is east of Gotland $\left(57^{\circ} 18.34^{\prime} \mathrm{N}\right.$, 2004.69'E; max. water depth 249 m; Fig. 1). For continuous CTD (conductivity, temperature, density) profiling, a Seabird sbe911+ instrument was used. $\mathrm{O}_{2}$ was measured using Winkler's method and $\mathrm{S}^{2-}$ colorimetrically with the methylene blue method, both as described by Grasshoff et al. (1983). Filter samples of ca. 200-250 l 
were taken from 10, 48, 80, 100, 108, 124 and 135 m water depth using a CTD pump on precombusted glass microfiber filters ( $\varnothing 30 \mathrm{~cm}$; $0.7 \mu \mathrm{m}$ pore size). The filters were kept frozen until analysis. Surface sediments were sampled at the same station using a Frahm corer during research cruise MSM16-1 in 2010. For sediment analysis ca. 2-3 g freeze dried sample were taken.

\subsubsection{Bulk CNS analysis}

Three pieces $(\varnothing 1.2 \mathrm{~cm}$ ) from different zones of each filter were combusted with $\mathrm{Vn}_{2} \mathrm{O}_{5}$ in a EuroVector EuroEA Elemental Analyzer. Sediment samples were also analyzed for bulk C/N/S. No acidification of the samples was performed, because suspended particulate material in the Gotland Sea was reported to be free of carbonate (Schneider et al., 2002), which was also demonstrated for the samples used for this study. The $\mathrm{C}, \mathrm{N}$ and $\mathrm{S}$ contents were calculated from comparisons with peak areas from a standard. The error in $\mathrm{C} / \mathrm{N} / \mathrm{S}$ analysis was $\pm 2 \%$ for $\mathrm{C}$, and $\pm 5 \%$ for $\mathrm{N}$ and $\mathrm{S}$.

\subsubsection{Extraction}

The sediment samples and half of each filter were extracted $(3 \mathrm{x}, 20 \mathrm{~min})$ with dichloromethane (DCM)/MeOH (40 ml; 3:1, v:v) in a CEM Mars 5 microwave (Matthews, NC, USA) at $80{ }^{\circ} \mathrm{C}$ and $800 \mathrm{~W}$. All extracts were combined.

\subsubsection{BHP acetylation and liquid chromatography-mass spectrometry (LC-MS)}

An aliquot of the extract (25\%) was acetylated using $\mathrm{Ac}_{2} \mathrm{O}$ and pyridine (1:1, v:v; $1 \mathrm{~h}$, $50{ }^{\circ} \mathrm{C}$; then overnight at room temperature). The mixture was then dried under vacuum and analyzed for BHPs using LC-MS. LC-MS was performed using a Prostar Dynamax HPLC system coupled to a 1200L triple quadrupole mass spectrometer (both Varian), equipped with a Merck Lichrocart (Lichrosphere 100; reversed phase (RP) $\mathrm{C}_{18 \mathrm{e}}$ column [250 x $\left.4 \mathrm{~mm}\right]$ ) and a Merck Lichrosphere pre-column of the same material. The solvent gradient profile was $100 \% \mathrm{~A}(0-1 \mathrm{~min})$ to $100 \% \mathrm{~B}$ at $35 \mathrm{~min}$, then isocratic to $60 \mathrm{~min}$ [solvent $\mathrm{A}$, MeOH/water $(9: 1 ; \mathrm{v}: \mathrm{v})$; solvent $\mathrm{B}$, $\mathrm{MeOH} /$ propan-2-ol (1:1; v:v); all Fisher Scientific HPLC grade]. The flow rate was 0.5 $\mathrm{ml} \mathrm{min}^{-1}$. The MS instrument was equipped with an atmospheric pressure chemical ionization (APCI) source operated in positive ion mode (capillary temperature 
$150{ }^{\circ} \mathrm{C}$, vaporizer temperature $400{ }^{\circ} \mathrm{C}$, corona discharge current $8 \mu \mathrm{A}$, nebulizing gas flow 70 psi and auxiliary gas 17 psi). Peaks from authentic BHP standards with known concentration (acetylated BHT and aminotriol) were compared with selected ions (SIM [single ion monitoring mode] mode) from acetylated BHP peaks in the samples to determine BHP concentration (external calibration). Assignment of BHPs was via MS characteristics and comparison with elution times of previously identified compounds. Response of BHPs was corrected for individual responses of amino- and non-amino-BHPs. The quantification error was estimated to be $\pm 20 \%$.

\subsubsection{PLFA fractionation, derivatization, gas chromatography-mass} spectrometry (GC-MS) and GC-combustion isotope ratio mass spectrometry (GCC-IRMS)

An aliquot (25\%) of the extract was separated via column chromatography into a hydrocarbon (F1), an alcohol and ketone (F2) and a polar fraction (F3) using a column ( $\varnothing$ ca. $1 \mathrm{~cm}$ ) filled with $7.5 \mathrm{~g}$ silica gel 60. The sample was dried on ca. 500 mg silica gel and placed on the column. After elution of F1 with $30 \mathrm{ml} n$-hexane/DCM 8:2 (v/v) and F2 with $30 \mathrm{ml}$ DCM/EtOAc 9:1 (v/v; data not shown), F3 was obtained with $100 \mathrm{ml}$ DCM/MeOH 1:1 (v/v) plus $100 \mathrm{ml} \mathrm{MeOH}$. To obtain the PLFAs, the polar fraction was separated using column chromatography of an aliquot (50\%) of F3, according to Sturt et al. (2004). Briefly, the column was filled with $2 \mathrm{~g}$ silica gel 60 and stored at $120^{\circ} \mathrm{C}$ until use. The sample was dried on ca. $500 \mathrm{mg}$ silica gel and added to the column. F3.1 (non-polar FAs) was eluted with $15 \mathrm{ml}$ DCM, F3.2 (glycolipid FAs) with $15 \mathrm{ml}$ acetone and F3.3 (PLFAs) with $15 \mathrm{ml} \mathrm{MeOH.} \mathrm{F3} \mathrm{and} \mathrm{F3.3}$ were methylated using trimethylchlorosilane in $\mathrm{MeOH}\left(1: 8 ; \mathrm{v} / \mathrm{v} ; 1.5 \mathrm{~h}, 80{ }^{\circ} \mathrm{C}\right)$. Double bond positions in unsaturated methyl esters were determined by derivatisation with dimethyldisulfide (DMDS; Carlson et al., 1989; Gatellier et al., 1993). The sample was dissolved in $100 \mu \mathrm{l} n$-hexane and $30 \mu \mathrm{I}_{2}$ solution (60 mg $\mathrm{I}_{2}$ in $1 \mathrm{ml} \mathrm{Et}{ }_{2} \mathrm{O}$ ) added. The sample was derivatized at $50{ }^{\circ} \mathrm{C}$ for $48 \mathrm{~h}$. Subsequently, $1 \mathrm{ml}$ of $n$-hexane and $200 \mu \mathrm{l}$ of $\mathrm{NaHSO}_{4}$ (5\% in water) were added and the hexane layer was pipetted of. The procedure was repeated $3 x$. The hexane phase was dried on ca. $500 \mathrm{mg}$ silica gel and added to a small column filled with ca. $1 \mathrm{~g}$ silica gel 60. It was eluted with 10 dead volumes of DCM. The methyl esters prepared from the polar fraction (F3) and the PLFAs (F3.3), and the DMDS derivatized samples were 
analyzed with GC-MS using a Varian CP-3800 chromatograph equipped with a fused silica column (Phenomenex Zebron ZB-5MS, $30 \mathrm{~m} \mathrm{x} 0.32 \mathrm{~mm}$ ) coupled to a $1200 \mathrm{~L}$ mass spectrometer, using He as carrier gas. The temperature program was $80{ }^{\circ} \mathrm{C}$ (3 min) to $310{ }^{\circ} \mathrm{C}$ (held $25 \mathrm{~min}$ ) at $4{ }^{\circ} \mathrm{C} \mathrm{min}^{-1}$. Compounds were assigned by comparing mass spectra and retention times with published data. The $\delta^{13} \mathrm{C}$ values of FAMEs from the polar fraction (F3) and the phospholipids (F3.3) were measured (2x) using a Trace GC gas chromatograph under the same conditions and equipped with the same column as for GC-MS, coupled to a Delta Plus isotope ratio mass spectrometer (both Thermo Scientific). The combustion reactor contained $\mathrm{CuO}, \mathrm{Ni}$ and Pt and was operated at $940{ }^{\circ} \mathrm{C}$. Isotopic composition values were calculated from comparisons with an isotopically known $\mathrm{CO}_{2}$ reference gas and are reported vs. Vienna Peedee Belemnite (V-PDB). GC-C-IRMS precision and linearity were checked daily by using an external n-alkane isotopic standard provided by A. Schimmelmann (Indiana University).

\subsection{Results}

\subsubsection{Bulk parameters}

The highest concentration of particulate organic carbon (POC) of $327 \mu \mathrm{g} \mathrm{l}^{-1}$ was in the surface water sample from $10 \mathrm{~m}$ (Table 1). The value was ca. 10x those of the deeper water samples. The lowest concentration $\left(27 \mu \mathrm{g} \mathrm{l}^{-1}\right)$ was at $100 \mathrm{~m}$ in the suboxic zone. The samples below showed a steady increase in POC concentration to $64 \mu \mathrm{g} \mathrm{l}^{-1}$ at $135 \mathrm{~m}$. Concentration of total organic carbon (TOC) in the surface sediment was $109 \mathrm{mg} \mathrm{g}^{-1} \mathrm{~d} . w$. (dry wt.) at 0-2 $\mathrm{cm}$ and $105 \mathrm{mg} \mathrm{g}^{-1} \mathrm{~d} . w$. at 6-8 cm.

\subsubsection{Physicochemical parameters for the water column}

The physicochemical parameters for the water column are given in Fig. 3 (Schmale et al., 2012). The pycnocline was at ca. $75 \mathrm{~m}$. Below the pycnocline, $\mathrm{O}_{2}$ decreased to $<0.2 \mathrm{ml} \mathrm{l}^{-1}$ at ca. $90 \mathrm{~m}$, defining the onset of the redoxcline and thus the upper boundary of the suboxic zone. $\mathrm{H}_{2} \mathrm{~S}$ was first detected at $138 \mathrm{~m}$ water depth, marking the upper boundary of the anoxic zone. Methane of biogenic origin $\left(\delta^{13} \mathrm{C} \mathrm{CH}_{4}\right.$ between $-82.4 \%$ and $-75.2 \%$ ) diffuses upwards from the underlying sediment into 


\begin{tabular}{|c|c|c|c|c|c|c|c|}
\hline \multirow{2}{*}{$\begin{array}{c}\begin{array}{c}\text { Water } \\
\text { depth }\end{array} \\
{[\mathrm{m}]}\end{array}$} & \multirow[t]{2}{*}{$\begin{array}{c}\text { Liters } \\
\text { pumped }\end{array}$} & \multirow{2}{*}{$\begin{array}{c}\mathrm{C}_{\mathrm{org}} \\
(\mathrm{POC}) \\
{\left[\mu \mathrm{g} \mathrm{Cl}^{-1}\right]}\end{array}$} & \multicolumn{2}{|c|}{ Total BHPs } & \multicolumn{3}{|c|}{ Fatty acids } \\
\hline & & & [ng/l] & {$\left[\mu \mathrm{g} \mathrm{g}^{-1} \mathrm{POC}\right]$} & $\begin{array}{c}\text { FAs } \\
{\left[\mathrm{mg} \mathrm{g}^{-1} \text { POC }\right]}\end{array}$ & $\begin{array}{c}\text { PLFAs } \\
{\left[\mathrm{mg} \mathrm{g}^{-1} \text { POC }\right]}\end{array}$ & $\begin{array}{l}\text { PLFA } \\
{[\%]}\end{array}$ \\
\hline 10 & 216 & 327 & 12.1 & 37.1 & 15.8 & 5.6 & 36 \\
\hline 48 & 219 & 39 & 6.6 & 166.4 & 9.3 & 3.3 & 36 \\
\hline 80 & 214 & 43 & & & 14.8 & 5.7 & 39 \\
\hline 100 & 214 & 28 & 27.8 & 996.5 & 5.5 & 3.8 & 70 \\
\hline 108 & 238 & 40 & 84.4 & 2108.4 & 6.1 & 3.0 & 50 \\
\hline 124 & 260 & $50^{*}$ & 38.3 & 765.1 & & & \\
\hline 135 & 211 & 64 & 189.0 & 3640.1 & 11.8 & 3.1 & 27 \\
\hline $\begin{array}{l}\text { Sediment } \\
\text { depth } \\
{[\mathrm{cm}]}\end{array}$ & $\begin{array}{c}\mathrm{g} \\
\text { sediment }\end{array}$ & $\begin{array}{c}\mathrm{C}_{\text {org }} \\
\text { (TOC) } \\
{\left[\mathrm{mg} \mathrm{Cg}^{-1} \text { sed.] }\right.}\end{array}$ & Tota & $\begin{array}{l}\text { BHPs } \\
{\left[\mu \mathrm{g} \mathrm{g}^{-1} \mathrm{TOC}\right]}\end{array}$ & & & \\
\hline $0-2$ & 2.5 & 109 & & 596.6 & & & \\
\hline $6-8$ & 3.8 & 105 & & 373.3 & & & \\
\hline
\end{tabular}

Tab. 1: General information on samples and concentrations of total BHPs, FAs, and PLFAs.

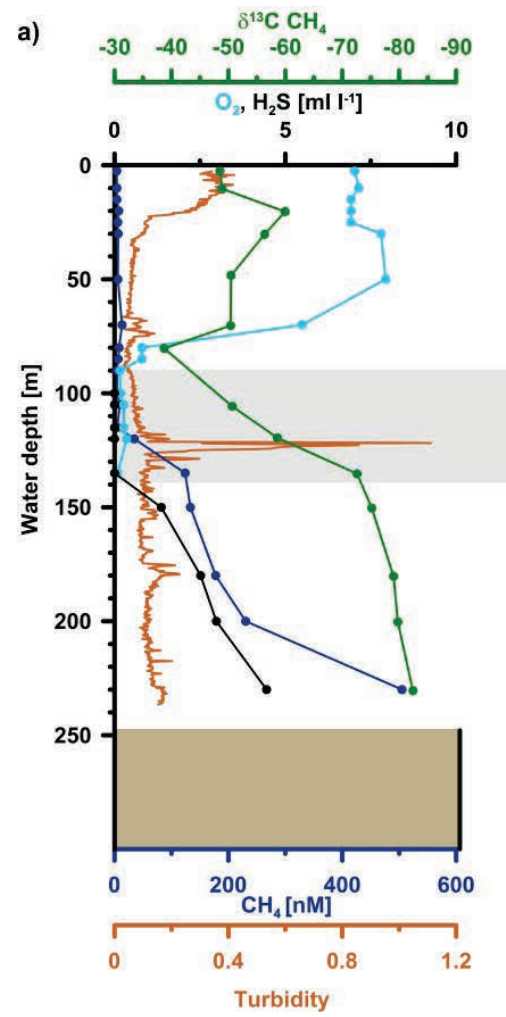

b)

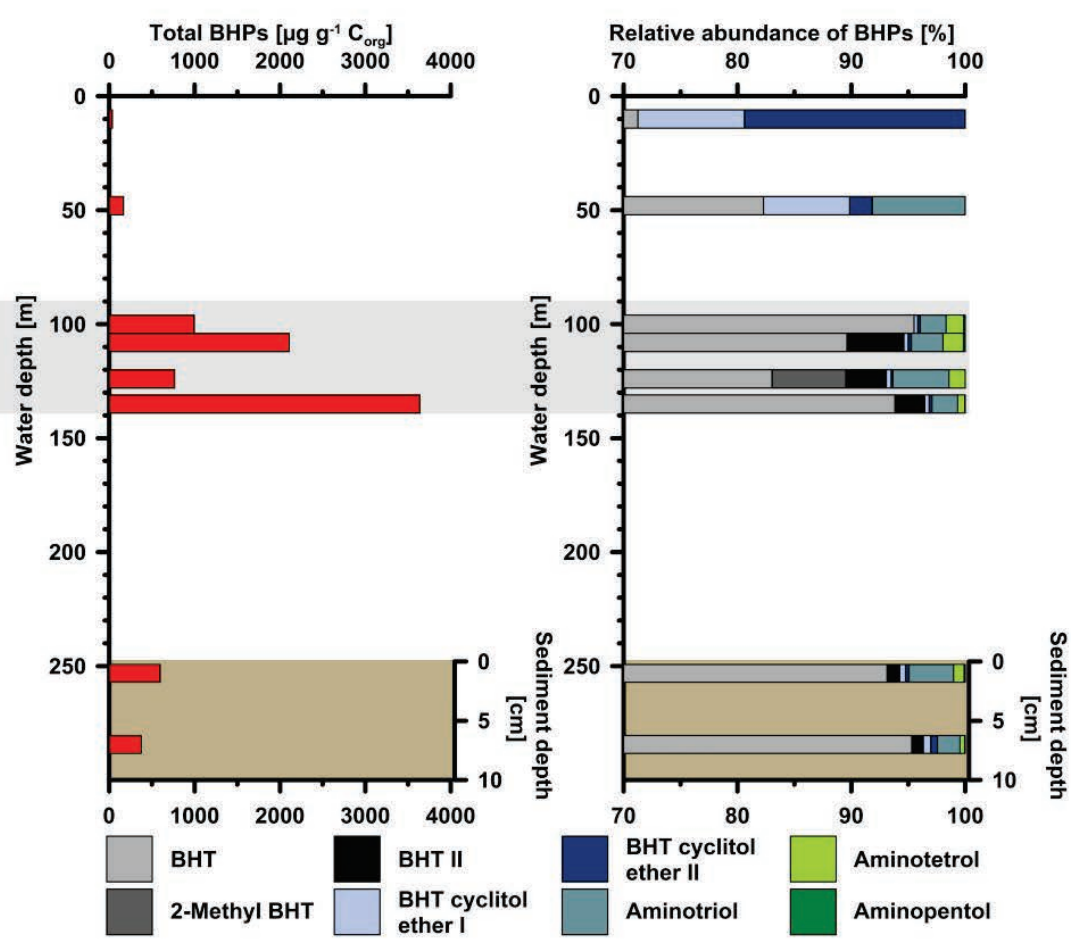

Fig. 2: Selected physicochemical parameters (Schmale et al., 2012) for the water column (a), concentration of total BHPs in Ig g_1 TOC (b) and distributions of BHPs in water column and sediment (c); distributions at $100 \mathrm{~m}$ are from Schmale et al., 2012); due to sample loss, no data are available for $80 \mathrm{~m}$. Gray shaded area is the suboxic zone. The relative amount of aminopentol in the water column is ca. $0.2 \%$ at $100 \mathrm{~m}$, ca. $0.2 \%$ at $108 \mathrm{~m}$, $0 \%$ at $124 \mathrm{~m}$, and ca. $0.1 \%$ at $135 \mathrm{~m}$, and ca. $0.1 \%$ in both sediment samples. 
the water column (Schmale et al., 2012). Thus, highest methane concentration was close to the sediment water interface (504 nM at $230 \mathrm{~m})$. Between ca. 135 and ca. $115 \mathrm{~m}$, it showed a strong decrease to near-zero values (Fig. 3a), along with a strong enrichment in ${ }^{13} \mathrm{C}$. The highest $\delta^{13} \mathrm{C} \mathrm{CH}_{4}$ value of $-38.7 \%$ was at ca. $80 \mathrm{~m}$ water depth (Schmale et al., 2012). The relative turbidity showed a maximum at ca. $122 \mathrm{~m}$, possibly caused by the precipitation of Fe and Mn oxides (Dellwig et al., 2010).

\subsubsection{BHPS}

Total concentration values of BHPs in the water column and sediment are given in Table 1 and Fig. 3b. Generally, the concentration in the water column was lower in the oxic than in the suboxic zone (Fig. 3b). The lowest was in the $10 \mathrm{~m}$ sample (40 $\mathrm{g}$ $\mathrm{g}^{-1}$ POC). With the exception of the sample from the turbidity maximum (124 m, 770 $\mu \mathrm{g} \mathrm{g}{ }^{-1}$ POC), concentration steadily increased with depth and showed a maximum at the lower boundary of the suboxic zone (135 m, $\left.3640 \mu \mathrm{g} \mathrm{g}^{-1} \mathrm{POC}\right)$. Total BHP concentration in the surface sediment samples was $600(0-2 \mathrm{~cm})$ and $370 \mu \mathrm{g} \mathrm{g}^{-1} \mathrm{TOC}$ (6-8 cm), respectively (Fig. 3b).

The distributions are given in Fig. 3c. In general, greater diversity was found in the samples from the suboxic zone and the sediment. The main hopanoid at all water depths was BHT (ca. $71 \%$ at $10 \mathrm{~m}$ and up to ca. $96 \%$ at $100 \mathrm{~m}$; Fig. 3c). In the suboxic zone (at 108, 124 and $135 \mathrm{~m}$ water depth) and in the two sediment samples a second BHT isomer, eluting directly behind BHT, was observed, with highest contribution (ca. 4\%) in the central suboxic zone (108 m). Two isomers of BHT cyclitol ether were present at every water depth and in the sediment. The nature of the isomerism for BHT and BHT cyclitol ether was not determined. BHT cyclitol ethers were most abundant in the oxic water samples. Another tetrafunctionalized BHP was 35-aminobacteriohopane-32,33,34-triol (aminotriol). It occurred in all samples, with the exception of the surface water sample. However, relative abundance was low with only ca. 2-8\% of total BHPs. The only pentafuctionalized BHP was 35-aminobacteriohopane-31,32,33,34-tetrol (aminotetrol), which was present in the suboxic zone and the sediment samples, but not in the shallow water samples. A similar depth distribution was found for 35-aminobacteriohopane30,31,32,33,34-pentol (aminopentol), which had highest abundance at $108 \mathrm{~m}$ water depth, but was not present in the turbidity maximum (124 m). Abundance of 


\begin{tabular}{|c|c|c|c|c|c|c|c|c|c|c|c|c|}
\hline \multirow[b]{2}{*}{ Component } & \multicolumn{2}{|l|}{$10 \mathrm{~m}$} & \multicolumn{2}{|l|}{$48 m$} & \multicolumn{2}{|l|}{$80 \mathrm{~m}$} & \multicolumn{2}{|c|}{$100 \mathrm{~m}$} & \multicolumn{2}{|c|}{$108 \mathrm{~m}$} & \multicolumn{2}{|c|}{$135 \mathrm{~m}$} \\
\hline & FA & PLFA & FA & PLFA & FA & PLFA & FA & PLFA & FA & PLFA & FA & PLFA \\
\hline$C 16: 1 \omega 9 t$ & 0.09 & 0.02 & 0.04 & 0.01 & 0.23 & 0.07 & 0.01 & 0.01 & 0.01 & 0.01 & 0.10 & 0.03 \\
\hline$C 16: 1 \omega 8 c$ & & & & & & & 0.03 & 0.03 & 0.04 & 0.02 & & \\
\hline$C 16: 1 \omega 8 t$ & & & & & & & 0.03 & 0.03 & 0.01 & 0.01 & & \\
\hline$C 16: 1 \omega 7 c$ & 2.24 & 0.79 & 0.25 & 0.19 & 0.55 & 0.28 & 0.23 & 0.21 & 0.23 & 0.18 & 1.38 & 0.44 \\
\hline$C 16: 1 \omega 7 t$ & 0.11 & 0.04 & 0.01 & & 0.12 & 0.04 & 0.06 & 0.03 & 0.05 & 0.04 & 0.13 & 0.03 \\
\hline$C 16: 1 \omega 5 c$ & & & 0.02 & 0.01 & 0.14 & 0.07 & 0.07 & 0.05 & 0.05 & 0.04 & 0.26 & 0.09 \\
\hline$C 16: 1 \omega 5 t$ & & & 0.01 & 0.01 & 0.11 & 0.03 & 0.02 & 0.01 & 0.03 & 0.02 & 0.12 & 0.02 \\
\hline C16:0 & 2.99 & 1.29 & 1.72 & 0.71 & 4.21 & 1.93 & 1.30 & 1.05 & 0.77 & 0.46 & 2.14 & 0.72 \\
\hline C18:1w9c & 0.76 & 0.34 & 0.93 & 0.20 & 2.14 & 0.45 & 0.25 & 0.12 & 0.38 & 0.09 & 0.84 & 0.21 \\
\hline$C 18: 1 \omega 7 c$ & 0.73 & 0.23 & 0.86 & 0.36 & 0.84 & 0.27 & 0.23 & 0.20 & 0.61 & 0.23 & 0.84 & 0.23 \\
\hline$C 18: 1 \omega 6 c$ & & & & & 0.10 & 0.05 & 0.02 & 0.01 & 0.03 & 0.01 & 0.05 & 0.01 \\
\hline C18:1w5c & 0.09 & 0.03 & 0.16 & 0.04 & 0.68 & 0.27 & 0.01 & 0.01 & 0.06 & 0.02 & 0.15 & 0.01 \\
\hline C18:0 & 0.59 & 0.18 & 2.99 & 1.12 & 2.57 & 1.01 & 2.28 & 1.45 & 2.37 & 1.28 & 2.58 & 0.79 \\
\hline
\end{tabular}

Tab. 2: Concentrations of individual FAs and PLFAs (mg g-1 POC; no data available for $124 \mathrm{~m}$ ).

\begin{tabular}{|c|c|c|c|c|c|c|c|c|c|c|c|c|}
\hline \multirow[b]{2}{*}{ Component } & \multicolumn{2}{|l|}{$10 \mathrm{~m}$} & \multicolumn{2}{|l|}{$48 \mathrm{~m}$} & \multicolumn{2}{|l|}{$80 \mathrm{~m}$} & \multicolumn{2}{|l|}{$100 \mathrm{~m}$} & \multicolumn{2}{|l|}{$108 \mathrm{~m}$} & \multicolumn{2}{|l|}{$135 \mathrm{~m}$} \\
\hline & FA & PLFA & FA & PLFA & FA & PLFA & FA & PLFA & FA & PLFA & FA & PLFA \\
\hline C16:1w9t & -32.7 & -31.1 & - & - & -15.5 & -27.5 & -22.2 & - & -27.1 & - & - & - \\
\hline C16:1w8c & & & & & & & -38.8 & -41.0 & -38.4 & -40.7 & & \\
\hline$C 16: 1 \omega 8 t$ & & & & & & & -30.4 & -33.5 & -27.4 & -26.1 & & \\
\hline$C 16: 1 \omega 7 c$ & -31.8 & -31.0 & -27.1 & -30.7 & -27.5 & -27.0 & -27.6 & -30.7 & -30.6 & -29.5 & -23.0 & -32.3 \\
\hline$C 16: 1 \omega 7 t$ & -32.2 & -32.7 & - & & - & - & - & -38.6 & -27.7 & -31.4 & -23.0 & -32.8 \\
\hline$C 16: 1 \omega 5 c$ & & & - & - & -22.2 & -25.7 & -35.7 & -37.7 & -41.4 & -41.2 & -29.5 & -29.9 \\
\hline$C 16: 1 \omega 5 t$ & & & -16.0 & -20.7 & -23.0 & -25.3 & -33.8 & -28.2 & -30.6 & -28.4 & -22.2 & -30.3 \\
\hline C16:0 & -31.2 & -31.7 & -29.1 & -28.8 & -25.6 & -25.6 & -26.9 & -28.4 & -26.9 & -26.9 & -27.5 & -26.6 \\
\hline C18:1w9c & -32.5 & -33.8 & -29.6 & -30.5 & -24.5 & -24.7 & -26.5 & -28.4 & -27.8 & -26.8 & -27.7 & -34.9 \\
\hline$C 18: 1 \omega 7 c$ & -27.4 & -24.9 & -24.0 & -24.7 & -24.2 & -25.0 & -24.9 & -24.5 & -24.1 & -23.7 & -19.2 & -22.2 \\
\hline C18:1w6c & & & & & -25.7 & -25.4 & -30.9 & -33.7 & -27.6 & -25.2 & -33.9 & -35.7 \\
\hline$C 18: 1 \omega 5 c$ & -27.7 & -27.6 & -20.2 & -21.4 & -23.1 & -23.3 & -20.2 & -23.8 & -21.0 & -18.2 & -19.1 & -24.1 \\
\hline C18:0 & -29.6 & -28.4 & -26.8 & -26.6 & -25.9 & -25.6 & -27.1 & -27.1 & -28.6 & -26.5 & -27.6 & -27.9 \\
\hline
\end{tabular}

Tab. 3: FA and PLFA $\delta^{13} \mathrm{C}$ values (\%) for $\mathrm{C} 16$ and $\mathrm{C} 18$ monounsaturated FAs (no data available for $124 \mathrm{~m})$.

aminotetrol and aminopentol was low, with a maximum of ca. 4\% for the first $(124$ $\mathrm{m}$ ) and ca. $0.2 \%$ for the latter $(108 \mathrm{~m})$.

\subsubsection{FAs}

Concentrations of total FAs and PLFAs are given in Table 1. FA concentration varied between a maximum of $15.8 \mathrm{mg} \mathrm{g}^{-1} \mathrm{POC}$ at $10 \mathrm{~m}$ water depth and a minimum of $5.5 \mathrm{mg} \mathrm{g}^{-1}$ POC at $100 \mathrm{~m}$ water depth. Concentration in the suboxic zone was generally lower than at the surface, with highest values at the lower boundary of the suboxic zone (135 m; $11.8 \mathrm{mg} \mathrm{g}^{-1}$ POC). PLFAs showed a similar trend of decreasing concentration in suboxic water, though less pronounced than for FAs. Except for the 48 m sample, where C18:0 was the most abundant PLFA, the oxic water samples 
were dominated by $\mathrm{C} 16: 0$, while the suboxic water samples were dominated by C18:0.

The concentration of individual FAs is presented in Table 2. Among the various homologues/isomers, $16: 1 \omega 8 \mathrm{c}, \quad 16: 1 \omega 5 \mathrm{c}$ and $16: 1 \omega 5 \mathrm{t}$ as markers for methanotrophic bacteria (Makula, 1978; Nichols et al., 1985; Bowman et al., 1991,

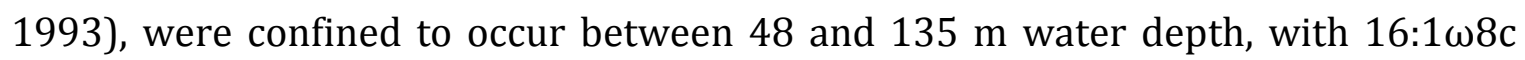
only occurring at $100 \mathrm{~m}$ and $108 \mathrm{~m}$ (Fig. 4). The $\delta^{13} \mathrm{C}$ values of PLFAs were also

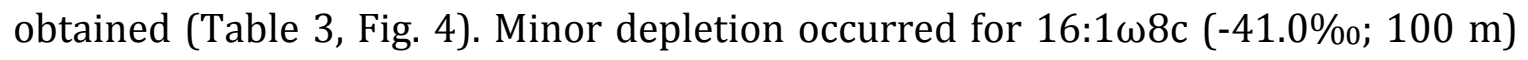
and $16: 1 \omega 5 \mathrm{c}(-41.2 \% ; 108 \mathrm{~m})$.

a) C16:1/C16:0 PLFA ratio

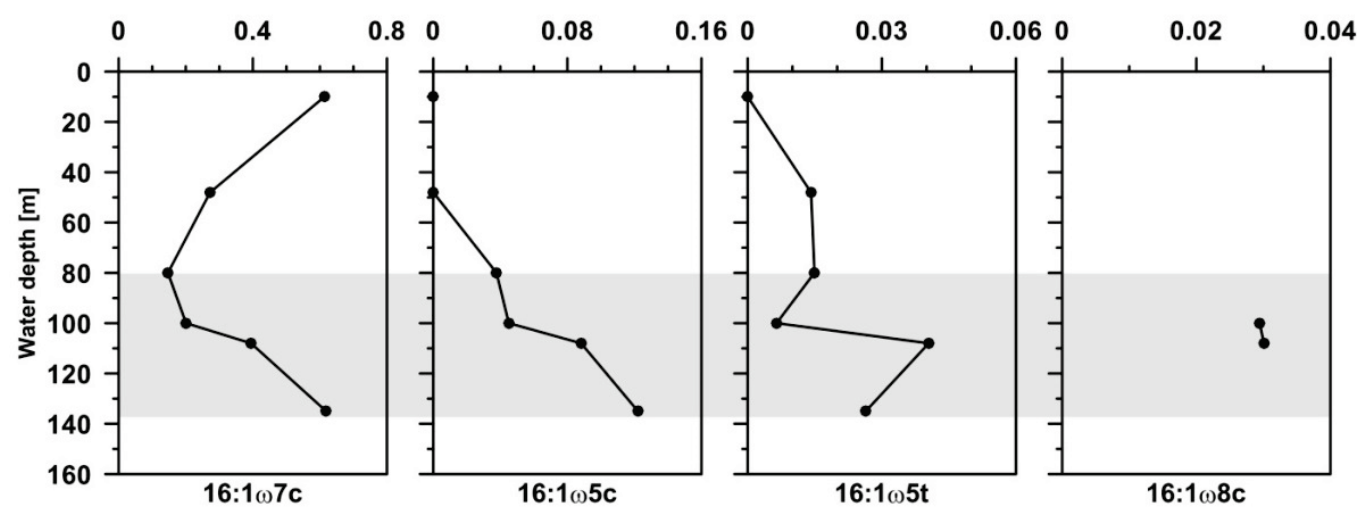

b) $\quad \delta^{13} \mathrm{C}$
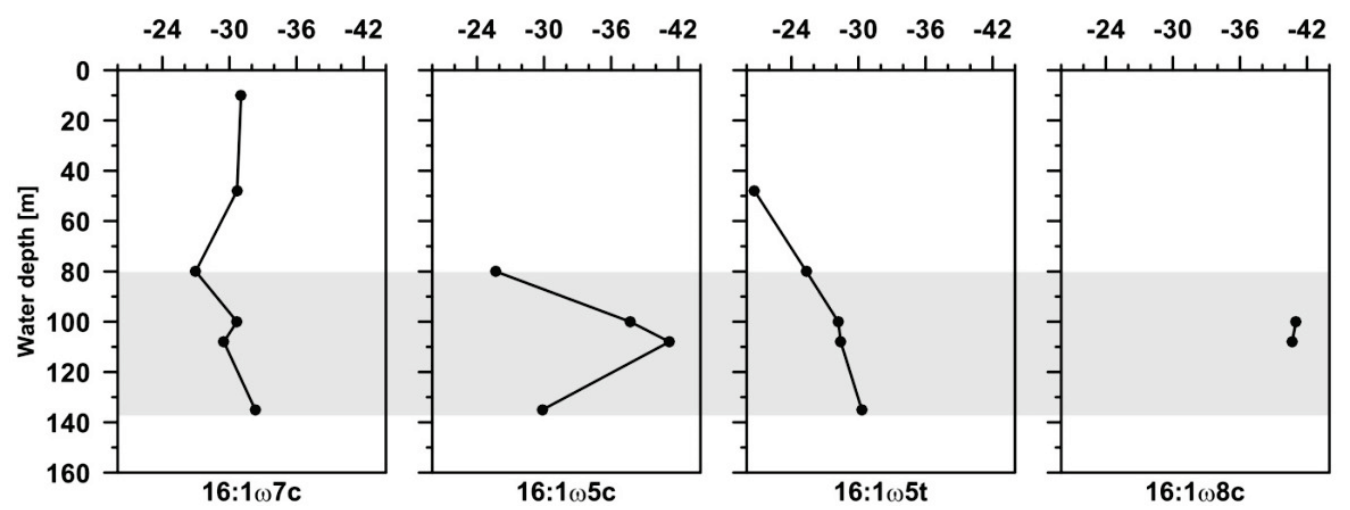

Fig. 3: $\mathrm{C} 16: 1 / \mathrm{C} 16: 0$ PLFA ratio and $\delta^{13} \mathrm{C}$ values for a non-specific $(16: 1 \omega 7 \mathrm{c})$ PLFA and for type I aerobic methanotroph-specific PLFAs. Gray shaded area is the suboxic zone.

\subsection{Discussion}

\subsubsection{Redox regime in water column of Gotland Deep}

Suboxic zones are important sites for microbial processes (Detmer et al., 1993;

Schubert et al., 2006; Labrenz et al., 2007). The rapid changes in the water column 
chemistry over a narrow depth interval support a number of different microbial metabolisms, ranging from oxic respiration to sulfate reduction, methanotrophy and methanogenesis (Teske et al., 1996; Labrenz et al., 2007). The redox regime in the water column of the Gotland Deep during the time of sampling has been recently described in detail (Schmale et al., 2012). Briefly, $\mathrm{O}_{2}$ concentration below the thermocline rapidly decreases with depth, with $0.2 \mathrm{ml} \mathrm{l}^{-1}$ reached at ca. $90 \mathrm{~m}$, marking the upper boundary of the suboxic zone. The lower boundary is defined by the onset of $\mathrm{H}_{2} \mathrm{~S}$, first detected at ca. $138 \mathrm{~m}$. Thus, the suboxic zone at the time of sampling was ca. $48 \mathrm{~m}$ thick. Methane concentration showed a strong decrease from the anoxic zone towards the center of the suboxic zone, along with enrichment in ${ }^{13} \mathrm{C}$ $\mathrm{CH}_{4}$. Both features indicate methane consumption (Schmale et al., 2012). The POC concentration was in good agreement with summer values from Brettar and Rheinheimer (1992). Maximum values in both cases occurred above the thermocline, corresponding to the zone of phytoplanktonic primary production in the euphotic zone. A second maximum at $135 \mathrm{~m}$ was consistent with a high abundance of microorganisms at that depth and/or organic particles accumulated at the suboxic/anoxic boundary.

\subsubsection{General biogeochemical aspects from BHP distributions}

In total, eight BHPs were found, but most were rather non-specific with respect to bacterial groups. BHT, BHT cyclitol ether and aminotriol are produced by various bacteria such as acetic acid bacteria, cyanobacteria, purple non-sulfur bacteria, methanotrophs, methylotrophs, and others (Rohmer et al., 1984; Neunlist and Rohmer, 1985a,b; Talbot et al., 2003a,b, 2008; Talbot and Farrimond, 2007). These non-specific hopanoids constituted $>90 \%$ of all BHPs. Surprisingly, the lowest concentration occurred in the samples from the euphotic zone (Table 1), where POC concentration and abundance of eukaryotic primary producers and cyanobacteria were highest (Detmer et al., 1993; Labrenz et al., 2007, Table 1). Some species of cyanobacteria are capable of BHP production, including a few marine nitrogen fixing cyanobacteria (Welander et al., 2010; Sáenz et al., 2012). Thus, cyanobacteria are regarded as possible producers of BHPs in aquatic environments (Summons et al., 1999, 2006). Likewise, the euphotic zone bacterioplankton was reported to be the main source of BHPs in sediments of the Black Sea (Blumenberg et al., 2009b). The 
low abundance of BHPs in the euphotic zone of the Gotland Deep may be explained by either the time of sampling, when cyanobacterial blooms had not yet occurred, or by a generally low abundance of BHP producing phototrophic bacteria in the central Baltic. The latter idea is supported by the fact that the key cyanobacteria in the central Baltic Sea (Labrenz et al., 2007) are relatives of the Synechococcus group, which contains only a few BHP producing strains (Talbot et al., 2008; Saenz et al., 2012). Future studies should test whether or not cyanobacteria are a significant source for BHPs in the central Baltic Sea.

The total concentration of BHPs strongly increased in the suboxic zone and showed a maximum at its lower boundary. This pattern has been described for the Black Sea (Blumenberg et al., 2007; Wakeham et al., 2007), as well as for the Arabian Sea, the Cariaco Basin and the Peru Margin (Sáenz et al., 2011). Although the synthesis of BHPs does not require the presence of $\mathrm{O}_{2}$ (Ourisson and Rohmer, 1982), BHPs were long thought to be produced only by aerobic bacteria (Ourisson et al., 1987; Innes et al., 1997). However, more recent studies have shown that BHPs also occur in an anaerobically grown Fe(III)-reducing Geobacter sp. (Fischer et al., 2005; Härtner et al., 2005), in bacteria capable of anaerobic $\mathrm{NH}_{4}{ }^{+}$oxidation (Sinninghe Damsté et al., 2004) and sulfate reducing bacteria (SRB; Blumenberg et al., 2006). Despite the source for most BHPs not being clear, our data support the idea that pelagic suboxic zones are an important habitat for BHP producing bacteria and/or zones where BHPs are physically enriched.

The diversity of BHP structures strongly increased in the suboxic zone. A methylated BHT occurred at $124 \mathrm{~m}$. The position of the methylation was not exactly identified, but elution characteristics suggest methylation at C-2. A 2-methyl BHT has been described by Wakeham et al. (2007) at the suboxic/anoxic boundary and in deeper anoxic water depths of the Black Sea. A second BHT isomer, eluting shortly after the common $22 R-17 \beta, 21 \beta$-BHT, occurred at 108 and $135 \mathrm{~m}$ water depth. Most likely, the same isomer (BHT II) has also been reported for sediments underlying the Benguela upwelling system (Watson, 2002; Blumenberg et al., 2010), the Peru margin (Watson, 2002; Sáenz et al., 2011), the Arabian Sea and the Cariaco Basin (Sáenz et al., 2011). The nature of the isomerism has not been elucidated, but for the Benguela upwelling system a $22 S$-configuration was suggested. As in our study, BHT II has been observed only in suboxic to anoxic environments (Sáenz et al., 2011). Thus, its 
occurrence in the suboxic zone of the Gotland Deep supports its utility as a biomarker for marine settings with an oxic-anoxic interface (Sáenz et al., 2011). The biological source(s) of BHT II remain(s) to be identified, but it may be produced by bacteria living in the suboxic zone. Alternatively, its presence may be due to yet unclear isomerization reactions of the common (22R-) BHT, or to physicochemical accumulation reactions. With the exception of the missing 2-methyl BHT, the diversity and the relative abundances of the compounds in the lower suboxic zone were reflected in the two sediment samples. This contradicts findings for the Black Sea (Blumenberg et al., 2009b), where BHPs in the sediment were related mainly to a bacterioplankton source from the euphotic zone. Although BHPs in the sediment reflect mainly those from the suboxic zone, a partial contribution from other bacteria living in the sediment cannot be completely excluded. A strong increase in bacterial numbers of SRB, including Desulfovibrio, and heterotrophic bacteria, was observed in the bottom water and the sediments of the Gotland Deep (Gast and Gocke, 1988; Bruns et al., 2002), and at least Desulfovibrio spp. are known BHP producers (e.g. Blumenberg et al., 2009a). Nonetheless, the similarity in BHPs in the suboxic zone and the underlying sediments strongly suggest that microbial processes in the suboxic water column are an important control on the composition and sedimentation of organic matter in the Gotland Deep.

\subsubsection{Biosignatures of methanotrophic bacteria in the suboxic zone of the Gotland Deep}

Bacteriohopanepolyols specific for methanotrophic bacteria were identified in the whole suboxic zone and the sediment samples. Aminotetrol is produced by methanotrophic bacteria (Neunlist and Rohmer, 1985a,b; Talbot et al., 2001; Talbot and Farrimond, 2007) and in minor amounts by SRB of the genus Desulfovibrio (Blumenberg et al., 2006, 2009a, 2012). Aminopentol, although also found in trace amounts in Desulfovibrio (Blumenberg et al., 2012), appears to remain an excellent biomarker for type I methanotrophic bacteria (Neunlist and Rohmer, 1985b; Cvejic et al., 2000; Talbot et al., 2001). C-3 methylated BHPs, although only present in a low number of aerobic methanotrophs from the Methylococcaceae group and thus a marker of minor significance (Welander and Summons, 2012), were not present in the Gotland Deep suboxic zone. They were also absent from the Black Sea samples 
described by Wakeham et al. (2007), but were observed in samples from the Black Sea suboxic zone Blumenberg et al., (2007). The presence of pelagic methanotrophic bacteria is supported by FA biomarkers. To better distinguish between dead cell material and cells living at the water sampling depth, PLFAs were analyzed separately from the total FAs, as PLFAs reflect signals from living cells (Fang et al., 2000). PLFA abundance showed a clear maximum in the central suboxic zone, pointing out the importance of this environment for active microbial processes. The PLFA fraction strongly decreases at the anoxic boundary, where dead cell material seems to accumulate. This is in good agreement with the increase in POC values at this depth (Table 1).

In particular, 16:1 $108 \mathrm{c}$ is regarded as a marker for type I methanotrophic bacteria of the genus Methylomonas (type I methanotroph), although it may occur in minor amounts in some species of Methylococcus, a type X methanotroph (Makula, 1978; Nichols et al., 1985; Bowman et al., 1991, 1993). As indicated by the presence of aminotetrol and aminopentol (Fig. 3), type I methanotrophic bacteria occur in the whole suboxic zone and are not restricted to the $100 \mathrm{~m}$ depth from which they were recently reported (Schmale et al., 2012). The distribution of 16:1 $\omega 8 \mathrm{c}$ in our samples supports this finding, although it was only detected in the central suboxic zone (100 and $108 \mathrm{~m}$ ) but not at the lower boundary (Fig. 4). Another FA related to type I

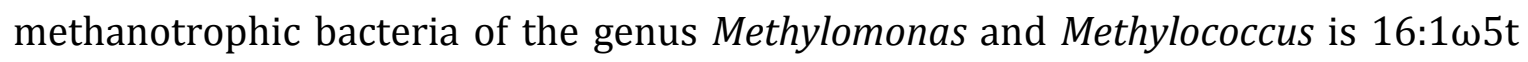
(Makula, 1978; Nichols et al., 1985; Bowman et al., 1993). It was detected at $48 \mathrm{~m}$ depth and below, with highest concentration at 135 and $80 \mathrm{~m}$. Its concentration decreased at 100 and $108 \mathrm{~m}$, where evidence for type I methanotrophic bacteria from other biomarkers was strongest. The 16:1/16:0 PLFA ratio (Fig. 4a) shows, however, the strongest increase in relative abundance of $16: 1 \omega 5 t$ - and all other relevant compounds - at $108 \mathrm{~m}$.

The ${ }^{13} \mathrm{C}^{13} \mathrm{CH}_{4}$ values in the redoxcline during the time of sampling were $-60 \%$ o to $-38 \%$ between 120 and $80 \mathrm{~m}$ depth (Schmale et al., 2012). The values for FAs from methanotrophic bacteria should therefore also reflect depletion in ${ }^{13} \mathrm{C}$, particularly if type I methanotrophs are key players (Jahnke et al., 1999; Schmale et al., 2012). Although PLFAs were considered as best reflecting in situ microbiological processes, trends in $\delta^{13} \mathrm{C}$ for FAs and PLFAs were largely identical (Table 2). Fig. 4b shows the $\delta^{13} \mathrm{C}$ values of selected PLFAs; $16: 1 \omega 7 \mathrm{c}$ is a common compound produced 
by a number of organisms. Thus, it does not show any peculiarity in its isotopic composition throughout the water column. In comparison, 16:1w8c shows a minor depletion $\left(\delta^{13} \mathrm{C}\right.$ as low as $-41 \%$, about $10 \%$ o lower than for $\left.16: 1 \omega 7 \mathrm{c}\right)$. The values for $16: 1 \omega 5 t$ continuously decreased with depth into the suboxic zone, although being generally higher than those of $16: 1 \omega 8 \mathrm{c}$ and $16: 1 \omega 5 \mathrm{c}$. The latter shows considerable ${ }^{13} \mathrm{C}$ depletion (up to $19 \%$ ) only in the central suboxic zone, vs. the sample depths above and below. This suggests the existence of both methanotrophic and methaneindependent source organisms for this particular compound. It therefore seems that alternative PLFA sources obscure the $\delta^{13} \mathrm{C}$ signals from methanotrophic bacteria. This is feasible for $16: 1 \omega 5 \mathrm{c}$, as a strong increase in the 16:1/16:0 PLFA ratio (Fig. 4) at the suboxic boundary argues for the increasing importance of SRB (Dowling et al., 1986; Oude Elferink et al., 1998). According to these observations, in conjunction with the low concentration of specific BHPs and PLFAs, the contribution of type I methanotrophic bacteria to the total bacterial biomass appears to be low. The abundance of aerobic methanotrophs in the Gotland Deep is similarly low as in the Black Sea, where a type I methanotrophic bacteria maximum of $4 \%$ occurred at the suboxic/anoxic boundary (Schubert et al., 2006). Typical biomarkers for type II

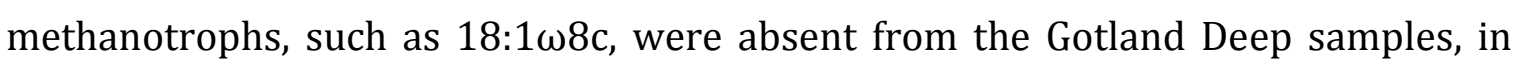
good agreement with molecular microbiological analysis (Schmale et al., 2012). The virtual absence of type II methanotrophs is a notable difference from the Black Sea, where such organisms have been observed (Gal'chenko et al., 1988; Durisch-Kaiser et al., 2005). As for other important biogeochemical processes (Glaubitz et al., 2009; Labrenz et al., 2010), aerobic methanotrophy at the redoxcline of the Gotland Deep appears to be restricted to a single group of organisms. Other organisms like the observed type I bacteria are most likely less adapted to the temporarily changing biogeochemical situation in the central Baltic Sea.

\subsection{Conclusions and outlook}

Aerobic methanotrophic bacteria thrive in the suboxic zone of the Gotland Deep water column (Baltic Sea). The methanotrophic community largely, if not exclusively, consists of type I methanotrophs, whereas there was no evidence for the presence of type II methanotrophs. Compound concentration and $\delta^{13} \mathrm{C}$ profiles of specific marker compounds suggest additional sources and a generally low 
abundance of aerobic methanotrophs among the bacterial community. Our study nevertheless demonstrates the utility of specific BHPs and FAs, along with compound specific isotopes, to reflect these aerobic methane-consuming processes in the water column. Moreover, BHPs in surface sediments mirror the distinctive distributions in the suboxic zone, demonstrating the capability of BHPs to enter the geological record as markers for a stratified setting.

Considering the results, a number of interesting questions remain. It is not known, for instance, how methanotrophic bacteria are affected by seasonal alteration of the suboxic zone by cyanobacterial blooms, or episodic salt water inflow. Moreover, the impact of other pathways of methanotrophy, particularly the anaerobic oxidation of methane, require further investigation. Using the potential of BHPs to reflect redoxcline processes in the sedimentary record, it will be interesting to test the extent to which microbial methanotrophy played a role in the Holocene history of the central Baltic Sea.

\section{Acknowledgments}

We are grateful to the captain, crew and shipboard party of the R/V Maria S. Merian cruises MSM08-3 and MSM16-1. We thank C. Conradt and M. Muschalla for laboratory assistance, J. Dyckmans from the KOSI (Göttingen) for help with stable isotope analysis, and T. Licha and C. Nödler for help with LC-MS. We thank two anonymous reviewers for comments and suggestions, which helped improving the manuscript. The Deutsche Forschungsgemeinschaft is thanked for financial support (Grants BL 971/1-3 and 971/3-1).

\section{References}

Andrén, E., Andrén, T., Kunzendorf, H., 2000. Holocene history of the Baltic Sea as a background for assessing records of human impact in the sediments of the Gotland Basin. The Holocene 10, 687-702.

Barnes, R.O., Goldberg, E.D., 1976. Methane production and consumption in anaerobic marine sediments. Geology 4, 297-300. 
Beal, E.J., House, C.H., Orphan, V.J., 2009. Manganese- and iron-dependent marine methane oxidation. Science 325, 184-187.

Blumenberg, M., Krüger, M., Nauhaus, K., Talbot, H.M., Oppermann, B.I., Seifert, R., Pape, T., Michaelis, W., 2006. Biosynthesis of hopanoids by sulfate-reducing bacteria (genus Desulfovibrio). Environmental Microbiology 8, 1220-1227.

Blumenberg, M., Seifert, R., Michaelis, W., 2007. Aerobic methanotrophy in the oxicanoxic transition zone of the Black Sea water column. Organic Geochemistry 38, 8491.

Blumenberg, M., Oppermann, B.I., Guyoneaud, R., Michaelis, W., 2009a. Hopanoid production by Desulfovibrio bastinii isolated from oilfield formation water. FEMS Microbiology Letters 293, 73-78.

Blumenberg, M., Seifert, R., Kasten, S., Bahlmann, E., Michaelis, W., 2009b. Euphotic zone bacterioplankton sources major sedimentary bacteriohopanepolyols in the Holocene Black Sea. Geochimica et Cosmochimica Acta 73, 750-766.

Blumenberg, M., Mollenhauer, G., Zabel, M., Reimer, A., Thiel, V., 2010. Decoupling of bio- and geohopanoids in sediments of the Benguela Upwelling System (BUS). Organic Geochemistry 41, 1119-1129.

Blumenberg, M., Hoppert, M., Krüger, M., Dreier, A., Thiel, V., 2012. Novel findings on hopanoid occurrences among sulfate reducing bacteria: is there a direct link to nitrogen fixation? Organic Geochemistry 49, 1-5.

Bodelier, P.L.E., Bär Gillisen, M.-J., Hordijk, K., Sinninghe Damsté, J.S., Rijpstra, W.I.C., Geenevasen, J.A.J., Dunfield, P.F., 2009. A reanalysis of phospholipid fatty acids as ecological biomarkers for methanotrophic bacteria. The ISME Journal 3, 606-617.

Bowman, J.P., Skeratt, J.H., Nichols, P.D., Sly, L.I., 1991. Phopsholipid fatty acid and lipopolysaccharide fatty acid signature lipids in methane-utilizing bacteria. FEMS Microbiology Ecology 85, 15-22.

Bowman, J.P., Sly, L.I., Nichols, P.D., Hayward, A.C., 1993. Revised taxonomy of the methanotrophs: description of Methylobacter gen. nov., emendation of 
Methylococcus, validation of Methylosinus and Methylocystis species, and a proposal that the family Methylococcaceae includes only the group I methanotrophs. International Journal of Systematic Bacteriology 43, 735-753.

Brettar, I., Rheinheimer, G., 1992. Influence of carbon availability on denitrification in the central Baltic Sea. Limnology and Oceanography 37, 1146-1163.

Bruns, A., Cypionka, H., Overmann, J., 2002. Cyclic AMP and acyl homoserine lactones increase the cultivation efficiency of heterotrophic bacteria from the Central Baltic Sea. Applied and Environmental Microbiology 68, 3978-3987.

Carlson, D.R., Roan, C.-S., Yost, R.A., Hector, J., 1989. Dimethyl disulfide derivatives of long chain alkenes, alkadiens, and alkatrienes for gas chromatography/mass spectrometry. Analytical Chemistry 61, 1564-1571.

Cvejic, J.H., Bodrossy, L., Kovács, K.L., Rohmer, M., 2000. Bacterial triterpenoids of the hopane series from the methanotrophic bacteria Methylocaldum spp.: phylogenetic implications and first evidence for an unsaturated aminobacteriohopanepolyol. FEMS Microbiology Letters 182, 361-365.

Dellwig, O., Leipe, T., März, C., Glockzin, M., Pollehne, F., Schnetger, B., Yakushev, E.V., Böttcher, M.E., Brumsack, H.-J., 2010. A new particulate Mn-Fe-P-shuttle at the redoxcline of anoxic basins. Geochimica et Cosmochimica Acta 74, 7100- 7115.

Detmer, A.E., Giesenhagen, H.C., Trenkel, V.M., Auf dem Venne, H., Jochem, F., 1993. Phototrophic and hetreotrophic pico- and nanoplankton in anoxic depths of the central Baltic Sea. Marine Ecology Progress Series 99, 197-203.

Dowling, N.J.E., Widdel, F., White, D.C., 1986. Phospholipid ester-linked fatty acid biomarkers of acetate-oxidizing sulphate-reducers and other sulphide-forming bacteria. Journal of General Microbiology 132, 1815-1825.

Durisch-Kaiser, E., Klauser, L., Wehrli, B., Schubert, C., 2005. Evidence of intense archaeal and bacterial methanotrophic activity in the Black Sea water column. Applied and Environmental Microbiology 71, 8099-8106. 
Ettwig, K.F., Butler, M.K., Le Paslier, D., Pelletier, E., Mangenot, S., Kuypers, M.M., Schreiber, F., Dutilh, B.E., Zedelius, J., de Beer, D., Gloerich, J., Wessels, H.J., van Alen, T., Luesken, F., Wu, M.L., van de Pas-Schoonen, K.T., Op den Camp, H.J., JanssenMegens, E.M., Francoijs, K.J., Stunnenberg, H., Weissenbach, J., Jetten, M.S., Strous, M., 2010. Nitrite-driven anaerobic methane oxidation by oxygenic bacteria. Nature 464, 543-548.

Fang, J., Barcelona, M.J., Semrau, J.D., 2000. Characterization of methanotrophic bacteria on the basis of intact phospholipid profiles. FEMS Microbiology Letters 189, $67-72$.

Fischer, W.W., Summons, R.E., Pearson, A., 2005. Targeted genomic detection of biosynthetic pathways: anaerobic production of hopanoid biomarkers by a common sedimentary microbe. Geobiology 3, 33-40.

Gal'chenko, V.F., Abranochkina, F.N., Bezrukova, L.V., Sokolova, E.N., Ivanov, M.V., 1988. Species composition of aerobic methanotrophic microflora in the Black Sea. Microbiology 57, 305-311.

Gast, V., Gocke, K., 1988. Vertical distribution of number, biomass and size-class spectrum of bacteria in relation to oxic/anoxic conditions in the Central Baltic Sea. Marine Ecology Progress Series 45, 179-186.

Gatellier, J.-P.L.A., de Leeuw, J.W., Sinninghe Damsté, J.S., Derenne, S., Largeau, C., Metzger, P., 1993. A comparative study of macromolecular substances of a Coorongite and cell walls of the extant alga Botryococcus braunii. Geochimica et Cosmochimica Acta 57, 2053-2068.

Glaubitz, S., Lueders, T., Abraham, W.R., Jost, G., Jurgens, K., Labrenz, M., 2009. ${ }^{13} \mathrm{C}$ isotope analyses reveal that chemolithoautotrophic Gamma- and Epsilonproteobacteria feed a microbial food web in a pelagic redoxcline of the central Baltic Sea. Environmental microbiology 11, 326-337.

Grasshoff, K., Kremling, K., Ehrhardt, M. (Eds.), 1983. Methods of Seawater Analysis. Verlag Chemie, Weinheim, Germany. 
Harff, J., Bohling, G., Davis, J.C., Endler, R., Kunzendorf, H., Olea, R.A., Schwarzacher, W., Voss, M., 2001. Physico-chemical stratigraphy of Gotland Basin Holocene sediments, the Baltic Sea. Baltica 14, 58-66

Härtner, T., Straub, K.L., Kannenberg, E., 2005. Occurrence of hopanoid lipids in anaerobic Geobacter species. FEMS Microbiology Letters 243, 59-64.

Innes, H.E., Bishop, A.N., Head, I.M., Farrimond, P., 1997. Preservation and diagenesis of hopanoids in recent lacustrine sediments of Priest Pot, England. Organic Geochemistry 26, 565-576.

IPCC, 2007. Changes in atmospheric constituents and in radiative forcing. In: Solomon, S., Qin, D., Manning, M., Chen, Z., Marquis, M., Averyt, K.B., Tignor, M., Miller, H.L., Climate Change: The Physical Science basis. Contribution of Working Group I to the Fourth Assessment Report of the Intergovernmental Panel on Climate Change (Eds.). Cambridge University Press, Cambridge, United Kingdom and New York, NY, USA, pp. 41-68.

Jahnke, L.L., Summons, R.E., Hope, J.M., Des Marais, D.J., 1999. Carbon isotopic fractionation in lipids from methanotrophic bacteria II: The effects of physiology and environmental parameters on the biosynthesis and isotopic signatures of biomarkers. Geochimica et Cosmochimica Acta 63, 79-93.

Labrenz, M., Jost, G., Jürgens, K., 2007. Distribution of abundant prokaryotic organisms in the water column of the central Baltic Sea with an oxic-anoxic interface. Aquatic Microbial Ecology 46, 177-190.

Labrenz, M., Sintes, E., Toetzke, F., Zumsteg, A., Herndl, G.J., Seidler, M., Jürgens, K., 2010. Relevance of a crenarchaeotal subcluster related to Candidatus Nitrosopumilus maritimus to ammonia oxidation in the suboxic zone of the central Baltic Sea. The ISME Journal 4, 1496-1508.

Lass, H.U., Matthäus, W., 2008. General oceanography of the Baltic Sea. In: Feistel, R., Nausch, G., Wasmund, N. (Eds.), State and Evolution of the Baltic Sea, 1952- 2005. John Wiley \& Sons, Inc., New Jersey, pp. 5-44. 
Makula, R.A., 1978. Phospholipid composition of methane-utilizing bacteria. Journal of Bacteriology 134, 771-777.

Matthäus, W., Schinke, H., 1999. The influence of river runoff on deep water conditions of the Baltic Sea. Hydrobiologia 393, 1-10.

Meier, H.E.M., Feistel, R., Piechura, J., Arneborg, L., Burchard, H., Fiekas, V., Golenko, N., Kuzmina, N., Mohrholz, V., Nohr, C., Paka, V.T., Sellschopp, J., Stips, A., Zhurbas, V., 2006. Ventilation of the Baltic Sea deep water: a brief review of present knowledge from observations and models. Oceanologia 48, 133-164.

Neunlist, S., Rohmer, M., 1985a. The hopanoids of 'Methylosinus trichosporium': aminobacteriohopanetriol and aminobacteriohopanetetrol. Journal of General Microbiology 131, 1363-1367.

Neunlist, S., Rohmer, M., 1985b. Novel hopanoids from the methylotrophic bacteria Methylococcus capsulatus and Methylomonas methanica. (22S)-35aminobacteriohopane-30,31,31,33,34-pentol and (22S)-35-amino-3 $\beta$ methylbacteriohopane- 30,31,32,33,34-pentol. Biochemical Journal 231, 635-639.

Nichols, P.D., Smith, G.A., Antworth, C.P., Hanson, R.S., White, D.C., 1985. Phospholipid and lipopolysaccharide normal and hydroxy fatty acids as potential signatures for methane-oxidizing bacteria. FEMS Microbiology Ecology, 327-335.

Oude Elferink, S.J.W.H., Boschker, H.T.S., Stams, A.J.M., 1998. Identification of sulfate reducers and Syntrophobacter sp. in anaerobic granular sludge by fatty-acid biomarkers and 16S rRNA probing. Geomicrobiology Journal 15, 3-17.

Ourisson, G., Rohmer, M., 1982. Prokaryotic polyterpenes: phylogenetic precursors of sterols. In: Bronner, F., Kleinzeller, A. (Eds.), Current Topics in Membranes and Transport. Academic Press, Inc., New York, pp. 153-182.

Ourisson, G., Rohmer, M., Poralla, K., 1987. Prokaryotic hopanoids and other polyterpenoid sterol surrogates. Annual Review of Microbiology 41, 301-333. 
Reeburgh, W.S., 1976. Methane consumption in Cariaco Trench waters and sediments. Earth and Planetary Science Letters 28, 337-344.

Reeburgh, W.S., 2007. Oceanic methane biogeochemistry. Chemical Reviews 107, 486-513.

Reissmann, J.H., Burchard, H., Feistel, R., Hagen, E., Lass, H.U., Mohrholz, V., Nausch, G., Umlauf, L., Wieczorek, G., 2009. State-of-the-art review on vertical mixing in the Baltic Sea and consequences for eutrophication. Progress in Oceanography 82, 4780.

Rohmer, M., Bouvier-Nave, P., Ourisson, G., 1984. Distribution of hopanoid triterpenes in prokaryotes. Journal of General Microbiology 130, 1137-1150.

Sáenz, J.P., Wakeham, S.G., Eglinton, T.I., Summons, R.E., 2011. New constraints on the provenance of hopanoids in the marine geologic record: bacteriohopanepolyols in marine suboxic and anoxic environments. Organic Geochemistry 42, 1351-1362.

Sáenz, J.P., Waterbury, J.B., Eglinton, T.I., Summons, R.E., 2012. Hopanoids in marine cyanobacteria: probing their phylogenetic distribution and biological role. Geobiology 10, 311-319.

Schmale, O., Schneider von Deimling, J., Gülzow, W., Nausch, G., Waniek, J.J., Rehder, G., 2010. Distribution of methane in the water column of the Baltic Sea. Geophysical Research Letters 37, L12604.

Schmale, O., Blumenberg, M., Kießlich, K., Jakobs, G., Berndmeyer, C., Labrenz, M., Thiel, V., Rehder, G., 2012. Aerobic methanotrophy within the pelagic redoxzone of the Gotland Deep (central Baltic Sea). Biogeosciences 9, 4969-4977.

Schneider, B., Nausch, G., Kubsch, H., Petersohn, I., 2002. Accumulation of total $\mathrm{CO}_{2}$ during stagnation in the Baltic Sea deep water and its relationship to nutrient and oxygen concentrations. Marine Chemistry 77, 277-291.

Schubert, C.J., Coolen, M.J., Neretin, L.N., Schippers, A., Abbas, B., Durisch-Kaiser, E., Wehrli, B., Hopmans, E.C., Damste, J.S., Wakeham, S., Kuypers, M.M., 2006. Aerobic 
and anaerobic methanotrophs in the Black Sea water column. Environmental Microbiology 8, 1844-1856.

Scranton, M.I., Crill, P., Angelis, M., Donaghay, P., Sieburth, J., 1993. The importance of episodic events in controlling the flux of methane from an anoxic basin. Biogeochemical Cycles 7, 491-507.

Sinninghe Damsté, J.S., Rijpstra, W.I.C., Schouten, S., Fuerst, J.A., Jetten, M.S.M., Strous, M., 2004. The occurrence of hopanoids in planctomycetes: implications for the sedimentary biomarker record. Organic Geochemistry 35, 561-566.

Sturt, H.F., Summons, R.E., Smith, K., Elvert, M., Hinrichs, K.U., 2004. Intact polar membrane lipids in prokaryotes and sediments deciphered by highperformance liquid chromatography/electrospray ionization multistage mass spectrometry - new biomarkers for biogeochemistry and microbial ecology. Rapid Communications in Mass Spectrometry 18, 617-628.

Summons, R.E., Jahnke, L.L., Hope, J.M., Logan, G.A., 1999. 2-Methylhopanoids as biomarkers for cyanobacterial oxygenic biosynthesis. Nature 400, 554-557.

Summons, R.E., Bradley, A.S., Jahnke, L.L., Waldbauer, J.R., 2006. Steroids, triterpenoids and molecular oxygen. Philosophical Transactions of the Royal Society of London: Series B, Biological Sciences 361, 951-968.

Talbot, H.M., Farrimond, P., 2007. Bacterial populations recorded in diverse sedimentary biohopanoid distributions. Organic Geochemistry 38, 1212-1225.

Talbot, H.M., Watson, D.F., Murrel, J.C., Carter, J.F., Farrimond, P., 2001. Analysis of intact bacteriohopanepolyols from methanotrophic bacteria by reversed-phase highperformance liquid chromatography-atmospheric pressure chemical ionisation mass spectrometry. Journal of Chromatography A 921, 175-185.

Talbot, H.M., Squier, A.H., Keely, B.J., Farrimond, P., 2003a. Atmospheric pressure chemical ionisation reversed-phase liquid chromatography/ion trap mass spectrometry of intact bacteriohopanepolyols. Rapid Communications in Mass Spectrometry $17,728-737$. 
Talbot, H.M., Summons, R.E., Jahnke, L.L., Farrimond, P., 2003b. Characteristic fragmentation of bacteriohopanepolyols during atmospheric pressure chemical ionisation liquid chromatography/ion trap mass spectrometry. Rapid Communications in Mass Spectrometry 17, 2788-2796.

Talbot, H.M., Summons, R.E., Jahnke, L.L., Cockell, C.S., Rohmer, M., Farrimond, P., 2008. Cyanobacterial bacteriohopanepolyol signatures from cultures and natural environmental settings. Organic Geochemistry 39, 232-263.

Taylor, J., Parkes, J., 1983. The cellular fatty acids of the sulphate-reducing bacteria, Desulfobacter sp., Desulfobulbus sp. and Desulfovibrio desulfuricans. Journal of General Microbiology 129, 3303-3309.

Teske, A., Wawer, C., Muyzer, G., Ramsing, N.B., 1996. Distribution of sulfate reducing bacteria in a stratified fjord (Mariager Fjord, Denmark) as evaluated by mostprobable-number counts and denaturing gradient gel electrophoresis of PCRamplified ribosomal DNA fragments. Applied and Environmental Microbiology 62, 1405-1415.

Wakeham, S.G., Hopmans, E.C., Schouten, S., Sinninghe Damsté, J.S., 2004. Archaeal lipids and anaerobic oxidation of methane in euxinic water columns: a comparative study of the Black Sea and Cariaco Basin. Chemical Geology 205, 427-442.

Wakeham, S.G., Amann, R., Freeman, K.H., Hopmans, E.C., Jørgensen, B.B., Putnam, I.F., Schouten, S., Sinninghe Damsté, J.S., Talbot, H.M., Woebken, D., 2007. Microbial ecology of the stratified water column of the Black Sea as revealed by a comprehensive biomarker study. Organic Geochemistry 38, 2070-2097.

Watson, D.F., 2002. Environmental distribution and sedimentary fate of hopanoid biological marker compounds. Newcastle upon Tyne, UK, University of Newcastle. Ph.D. Thesis.

Welander, P.V., Summons, R.E., 2012. Discovery, taxonomic distribution, and phenotypic characterization of a gene required for 3-methylhopanoid production. Proceedings of the National Academy of Sciences of the USA 109, 12905-12910. 
Welander, P.V., Coleman, M.L., Sessions, A.L., Summons, R.E., Newman, D.K., 2010. Identification of a methylase required for 2-methylhopanoid production and implications for the interpretation of sedimentary hopanes. Proceedings of the National Academy of Sciences of the USA 109, 8537-8542. 


\section{Bacteriohopanepolyols record stratification, nitrogen fixation and other biogeochemical perturbations in Holocene sediments of the central Baltic Sea}

Martin Blumenberg, Christine Berndmeyer, Matthias Moros, Melanie Muschalla, Oliver Schmale, and Volker Thiel

Biogeosciences (2013) 10, 2725-2735.

DOI: 10.5194/bg-10-2725-2013, Open Access

\subsection{Abstract}

The Baltic Sea, one of the world's largest brackish-marine basins, established after deglaciation of Scandinavia about 17000 to $15000 \mathrm{yr}$ ago. In the changeable history of the Baltic Sea, the initial freshwater system was connected to the North Sea about 8000 yrs ago and the modern brackish-marine setting (Littorina Sea) was established. Today, a relatively stable stratification has developed in the water column of the deep basins due to salinity differences. Stratification is only occasionally interrupted by mixing events, and it controls nutrient availability and growth of specifically adapted microorganisms and algae. We studied bacteriohopanepolyols (BHPs), lipids of specific bacterial groups, in a sediment core from the central Baltic Sea (Gotland Deep) and found considerable differences between the distinct stages of the Baltic Sea's history. Some individual BHP structures indicate contributions from as yet unknown redoxcline-specific bacteria (bacteriohopanetetrol isomer), methanotrophic bacteria (35aminobacteriohopanetetrol), cyanobacteria (bacteriohopanetetrol cyclitol ether isomer) and from soil bacteria (adenosylhopane) through allochthonous input after the Littorina transgression, whereas the origin of other BHPs in the core has still to be identified. Notably high BHP abundances were observed in the deposits of the brackish-marine Littorina phase, particularly in laminated sediment layers. Because these sediments record periods of stable water column stratification, bacteria specifically adapted to these conditions may account for the high portions of BHPs. 
An additional and/or accompanying source may be nitrogen-fixing (cyano)bacteria, which is indicated by a positive correlation of BHP abundances with $\mathrm{C}_{\text {org }}$ and $\delta^{15} \mathrm{~N}$.

\subsection{Introduction}

The Baltic Sea had a variable geological and biogeochemical history after it originated 17 000-15 $000 \mathrm{yr}$ before present (BP; see comprehensive summary in Andrén et al., 2011). After deglaciation of Scandinavia, the closed basin of the modern Baltic Sea was filled with melt water and a freshwater system developed around $16000 \mathrm{yr}$ BP, the so-called Baltic Ice Lake. This oligotrophic lake setting was terminated about $11700 \mathrm{yr}$ BP by a pulse of marine water that entered the Baltic Sea via a passage through south-central Sweden and led to a slightly brackish environment (Yoldia Sea). Freshwater conditions re-established about 10700 yr BP (Ancylus Lake), until the major marine transgression took place via the Kattegat, resulting in the establishment of the modern Littorina Sea. The onset of the Littorina Sea stage is still a matter of discussion (see e.g. Rößler et al., 2011). Dating based on calcareous fossils revealed 8100-8000 yr BP in the Great Belt (e.g. Bennike et al., 2004) and Mecklenburg Bight (Rößler et al., 2011), and 7200 yr BP in Arkona Basin (e.g. Moros et al., 2002). Bulk sediment dates revealed older ages of 8500-8000 yr BP for the onset in Bornholm Basin (Andrén et al., 2000a) and Gotland Basin (Andrén et al., 2000b).

The ingression of marine North Sea waters led to the development of a stratified water body in the deep basins of the central Baltic Sea, with more saline, denser waters in the lower water column. Such conditions also characterize one of the deepest basins of the modern Baltic Sea - the Gotland Deep (249 m water depth). In this basin there exists a relatively stable oxic-anoxic transition zone (redoxcline) at about $100 \mathrm{~m}$ water depth. The stratification of the Gotland Deep is only occasionally disturbed by turbulent vertical transport processes and inflows of North Sea water (Reissmann et al., 2009). The stratification has major consequences on the nutrient situation of the central Baltic Sea and the composition of pelagic micro- and macroorganisms (e.g. Labrenz et al., 2007; Schmale et al., 2012). For instance, high nutrient input with excess phosphorus loads promotes growth of nitrogen-fixing cyanobacteria (Nausch et al., 2009; Wasmund et al., 2012). 
Numerous micropalaeontological and biogeochemical studies on the Holocene in the central Baltic Sea exist, mainly reflecting the change from oligotrophic freshwater conditions (Ancylus Lake) to a brackish-marine setting (Littorina Sea) with widespread deep water anoxia (e.g. Sohlenius et al., 1996; Bianchi et al., 2000; Brenner, 2001, 2005; Voss et al., 2001). As a result of the Littorina Sea transgression, marine diatoms and dinoflagellates entered the central Baltic Sea (Brenner, 2005), and cyanobacteria became increasingly important as indicated by pigment and molybdenum abundances (Bianchi et al., 2000; Kunzendorf et al., 2001; Poutanen and Nikkila, 2001; Borgendahl and Westman, 2007). Due to the lack of preservable cell remnants, however, information about the microbial protagonists of biogeochemical cycling in the changeful history of the central Baltic Sea is scarce. An organic geochemical approach was made by Nytoft and Larsen (2001), who reported changes in the composition of bacterial hopanoid hydrocarbons from the Gotland Deep and concluded that bacteria became more prominent during the Littorina Sea stage. Our study aims to specify these bacterial contributions to the Holocene sediments of the Gotland Deep by using one of the most ubiquitous classes of lipids, bacteriohopanepolyols (BHPs). BHPs are produced by many groups of bacteria and are excellently suitable for palaeoreconstructions of contributions from metabolically and phylogenetically distinct bacteria into lake and marine sediments (e.g. Talbot and Farrimond, 2007; Coolen et al., 2008; Blumenberg et al., 2009; Taylor and Harvey, 2011). So far, only one report of BHPs from surface sediments of the central Baltic Sea exists (Berndmeyer et al., 2013). This study focused on BHPs from methanotrophic bacteria living in the redoxcline of the Gotland Deep water column and clearly demonstrated the utility of BHPs to reflect water column processes. The current study is aimed at BHPs and selected other biomarkers in deeper Holocene sediments of the Gotland Deep. Our goal is to bridge the gap between the relatively well known record of eukaryotic remains and the much less understood bacteria and, by that, to get a better understanding of bacterial primary production and redoxcline-related processes in the geological history of the central Baltic Sea. 


\subsection{Study site and core stratigraphy}

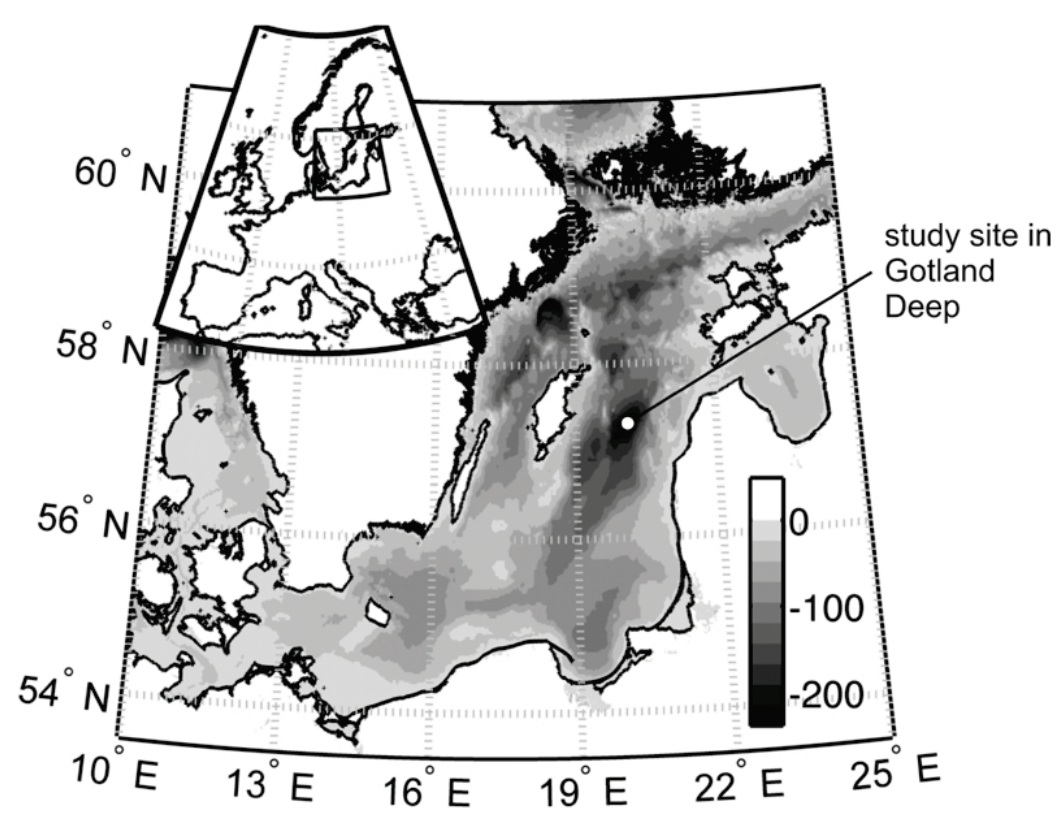

Fig. 1: Study site (station 52-07) in the central Baltic Sea.
During a research cruise with RV Maria S. Merian in summer 2010, an $11.6 \mathrm{~m}$ long gravity core, together with a "Frahmlot" core to obtain undisturbed surface layers, were taken in the Gotland Deep (240 m water depth; station MSM 16- 1 52-07; coordinates:

57016.998; E $20.7182^{\circ}$; for sampling site see Fig. 1). The cores cover sedimentary depositions of all stages of the Baltic Sea's history. Sediment depths in the figures are composites resulting from lithostratigraphic correlation of the gravity and the Frahmlot corer. The deposits of the Baltic Ice Lake were characterised by brownish and clayish sediments with low visible organic matter content $(\sim 1000$ to $680 \mathrm{~cm}$ below sea floor (cmbsf); Fig. 2). Similarly organic-lean Ancylus Lake sediments were found between 680 to $\sim 440 \mathrm{cmbsf}$. A black colour in the upper Ancyclus Lake layer is most likely due to precipitation of sulphide bands after downward diffusion of $\mathrm{H}_{2} \mathrm{~S}$ from sulfate reduction in the overlying Littorina Sea deposits (Boesen and Postma, 1988; Sohlenius et al., 1996; Moros et al., 2002). The brackish-marine Littorina Sea sediments start at $440 \mathrm{cmbsf}$ and partially show fine lamination, characterizing times of pronounced and stable deep water anoxia. Strongly laminated sediments between 60 and $90 \mathrm{cmbsf}$ and in the uppermost $20 \mathrm{cmbsf}$ most likely represent deposits of the warm stages Medieval Climate Anomaly (MCA, from AD 950 to 1250 ) and the Modern Warm Period (MoWP, since $\sim$ AD 1850), respectively, while the organic-lean sediments in between record the Little Ice Age (LIA, from $\sim$ AD 1350 to 1850; ages inferred from Kabel et al., 2012). 


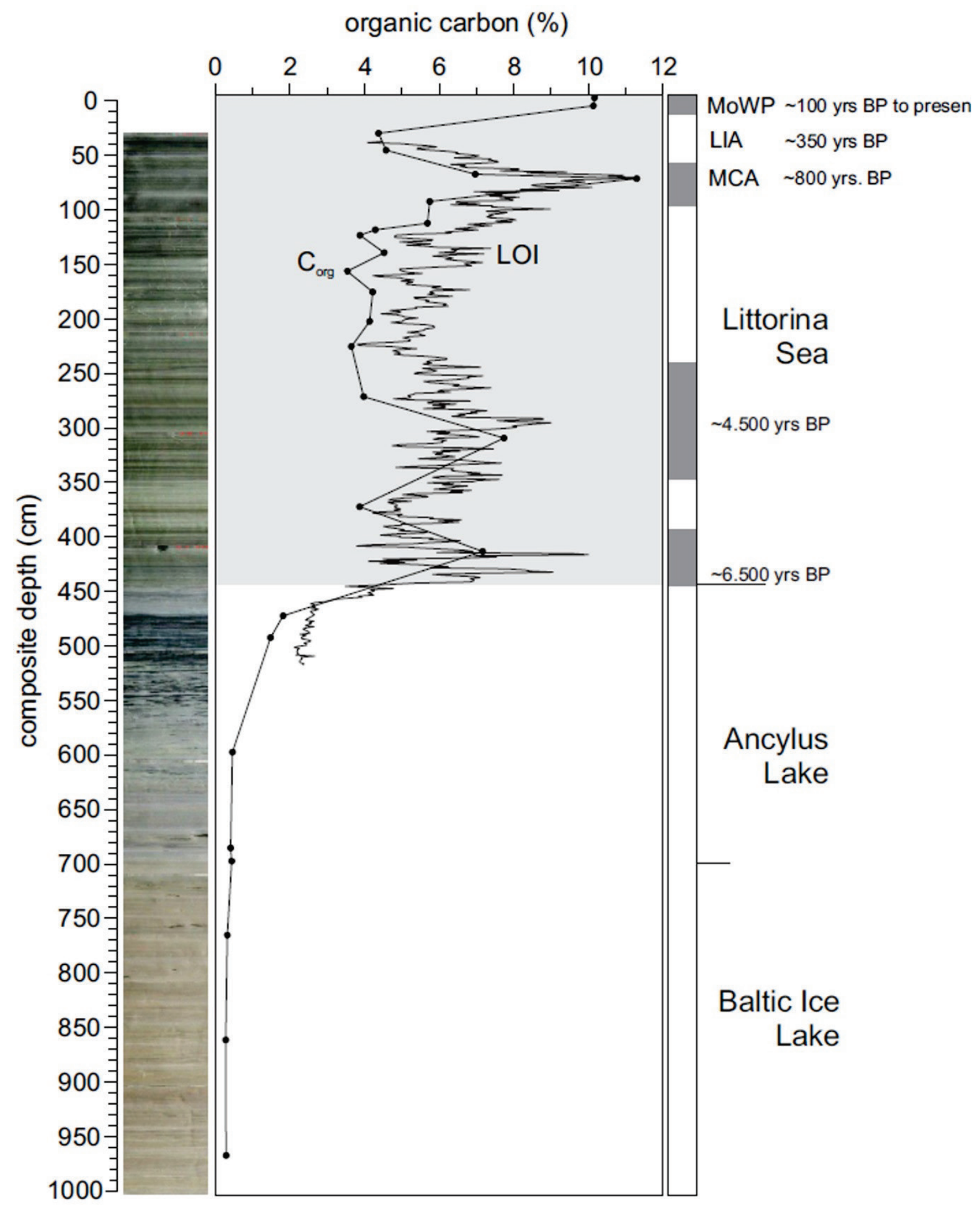

Fig. 2: $\mathrm{C}_{\text {org }}$ concentrations of the samples used for biomarker analyses in comparison with LOI (loss on ignition) data obtained at higher resolution. Dark grey areas in the column on the right represent sediments with strong lamination and thus pronounced and stable water column stratification during the Littorina Sea stage. Layers in between lacked strong bottom water anoxia, at least for extended periods of time. Ages are inferred from correlations with the master core described in Lougheed et al. (2012). In the central Baltic Sea, LOI have to be divided by approximately 2.5 to obtain $C_{\text {org }}$ abundances (Leipe et al., 2010). LIA=Little Ice Age; MCA=Medieval Climate Anomaly, MoWP=Modern Warm Period. 


\subsection{Materials and methods}

\subsubsection{Sample preparation and bulk analyses ( $\left.C_{o r g}, N, \delta^{15} N, L O I\right)$}

The core was stored cool on board and in the laboratory until sampling in February 2011 (samples for biomarker and bulk analyses were then stored frozen until further analyses). The upper three samples were obtained from the accompanying Frahmlot (MSM 16-1 52-04) and data were taken from Berndmeyer et al. (2013). The samples were homogenized by grinding, and aliquots were taken for elemental analyses (C /N/ S) using a Eurovector Euro EA CNS analyser. To determine the contents of organic carbon $\left(\mathrm{C}_{\mathrm{org}}\right)$, each sample was also analysed after decarbonatisation with $\mathrm{HCl}$. The error for $\mathrm{C}$ and $\mathrm{N}$ analyses are generally $<2$ and $5 \%$, respectively. Bulk $\delta^{15} \mathrm{~N}$ isotope analysis was carried out in duplicate using elemental analysis-isotope ratio mass spectrometry (EA-IRMS, Delta plus, Thermo scientific). The lab standard deviation of this method is $0.1 \%$. The loss on ignition (LOI) was determined in high resolution for the upper $500 \mathrm{~cm}$ of the gravity core by ashing freeze-dried samples at $550{ }^{\circ} \mathrm{C}(3 \mathrm{~h})$ and calculating the resulting mass difference (wt.\%).

\subsubsection{Extraction, column chromatography and derivatisation}

About $7.5 \mathrm{~g}$ of the sediments was extracted three times (20 min) with $40 \mathrm{ml}$ of a mixture of dichloromethane (DCM) and methanol (MeOH) $(3: 1, v / v)$ in a CEM Mars 5 microwave (Matthews, NC, USA) at $80{ }^{\circ} \mathrm{C}$ and $800 \mathrm{~W}$. An aliquot of the combined extract was acetylated and analysed for bacteriohopanepolyols by liquid chromatographymass spectrometry (LC-MS; see below). Acetylation was performed using a mixture of acetic acid anhydride and pyridine $\left(1: 1, \mathrm{v} / \mathrm{v}, 50{ }^{\circ} \mathrm{C}\right.$ for $1 \mathrm{~h}$ and overnight at room temperature). The pyridine/acetic acid anhydride mixture was then dried under vacuum. Another aliquot was separated by column chromatography into a hydrocarbon (F1), a ketone and alcohol (F2), and a polar fraction (F3; details are described in Blumenberg et al., 2009). Resulting alcohols in the F2 were silylated using BSTFA (N,O-bis[trimethylsilyl]trifluoroacetamide) for $1.5 \mathrm{~h}$ at $80^{\circ} \mathrm{C}$. 


\subsubsection{Gas chromatography-mass spectrometry (GC-MS)}

The hydrocarbon and alcohol fractions (F1 and F2) were analysed using GC-MS (Varian CP-3800 chromatograph coupled to a 1200L mass spectrometer), and peaks were identified by comparing mass spectra and retention times with published data. The system was equipped with a fused silica column (Phenomenex Zebron ZB-5MS, $30 \mathrm{~m}, 0.25 \mu \mathrm{m}$ film thickness, i.d. $0.32 \mathrm{~mm}$ ). Helium was used as carrier gas and the temperature program was $80^{\circ} \mathrm{C}(3 \mathrm{~min})$ to $310^{\circ} \mathrm{C}$ at $4{ }^{\circ} \mathrm{C} \mathrm{min}^{-1}$ (held $25 \mathrm{~min}$ ).

\subsubsection{Liquid chromatography-mass spectrometry (LC-MS)}

Details about LC-MS analyses and quantification of bacteriohopanepolyols (BHPs) can be found elsewhere (Blumenberg et al., 2010). Briefly, LC-MS was performed using a Prostar Dynamax High-Performance Liquid Chromatography (HPLC) system interfaced with a 1200L triple quadrupole mass spectrometer (both Varian). HPLC separation was achieved using a Merck Lichrocart (Lichrosphere 100; RPC18e $5 \mu \mathrm{m}$ column; $250 \times 4 \mathrm{~mm}$ ) and a Merck Lichrosphere pre-column of the same material. Quantifications were done using external standards of BHPs, bacteriohopanetetrol and 35-aminobacteriohopanetriol, with known concentrations. Routine replicate analyses of the standard BHPs revealed an error in quantification of $\pm 20 \%$.

\subsection{Results}

\subsubsection{Bulk geochemical data and stratigraphy}

$\mathrm{C}_{\text {org }}$ as well as high-resolution LOI data are presented in Fig. 2. In the central Baltic Sea, LOI (\%) approximately mirrors $C_{\text {org }}(\%)$, if divided by 2.5 (Leipe et al., 2010), and this conversion factor appears to be also valid for the studied core from the Gotland Deep (see converted LOI data in Fig. 2). The high resolution of LOI data allowed a comparison with dated cores from the same area (Lougheed et al., 2012; see supplementary figure). Four maxima in $\mathrm{C}_{\mathrm{org}}$ were found, the lower of which represents the establishment of the Littorina Sea (about $440 \mathrm{cmbsf}$; peak at 420 cmbsf $\sim 6500 \mathrm{yr} \mathrm{BP}$ ), the peak at $290 \mathrm{cmbsf}$ represents $4500 \mathrm{yr}$ BP, and the peak at $70 \mathrm{cmbsf}$ that of the MCA (maximising at $\sim 800 \mathrm{yr}$ BP). The uppermost $\mathrm{C}_{\text {org }}$ maximum records the MoWP of the last $100 \mathrm{yr}$ ( $\mathrm{C}_{\text {org }}$ data from Frahmlot).

In Fig. 3, $\mathrm{C}_{\text {org }}$ is compared with $\delta^{15} \mathrm{~N}$ and $\mathrm{C} / \mathrm{N}$ ratios. As clearly demonstrated in Fig. $3 \mathrm{~b}, \mathrm{C}_{\text {org }}$ and $\delta^{15} \mathrm{~N}$ are excellently negatively correlated ( $p$ value $3 \times 10^{-7}$; excluding the surface samples). Lowest $\mathrm{C} / \mathrm{N}$ ratios of about 5 were observed during the Baltic Ice 
Lake and Ancylus Lake stages and highest $\mathrm{C} / \mathrm{N}$ values of about 10 in sediments deposited during the Littorina stage. The maximum value of 12.9 was observed in the deepest sediment sample of the Littorina Sea stage.

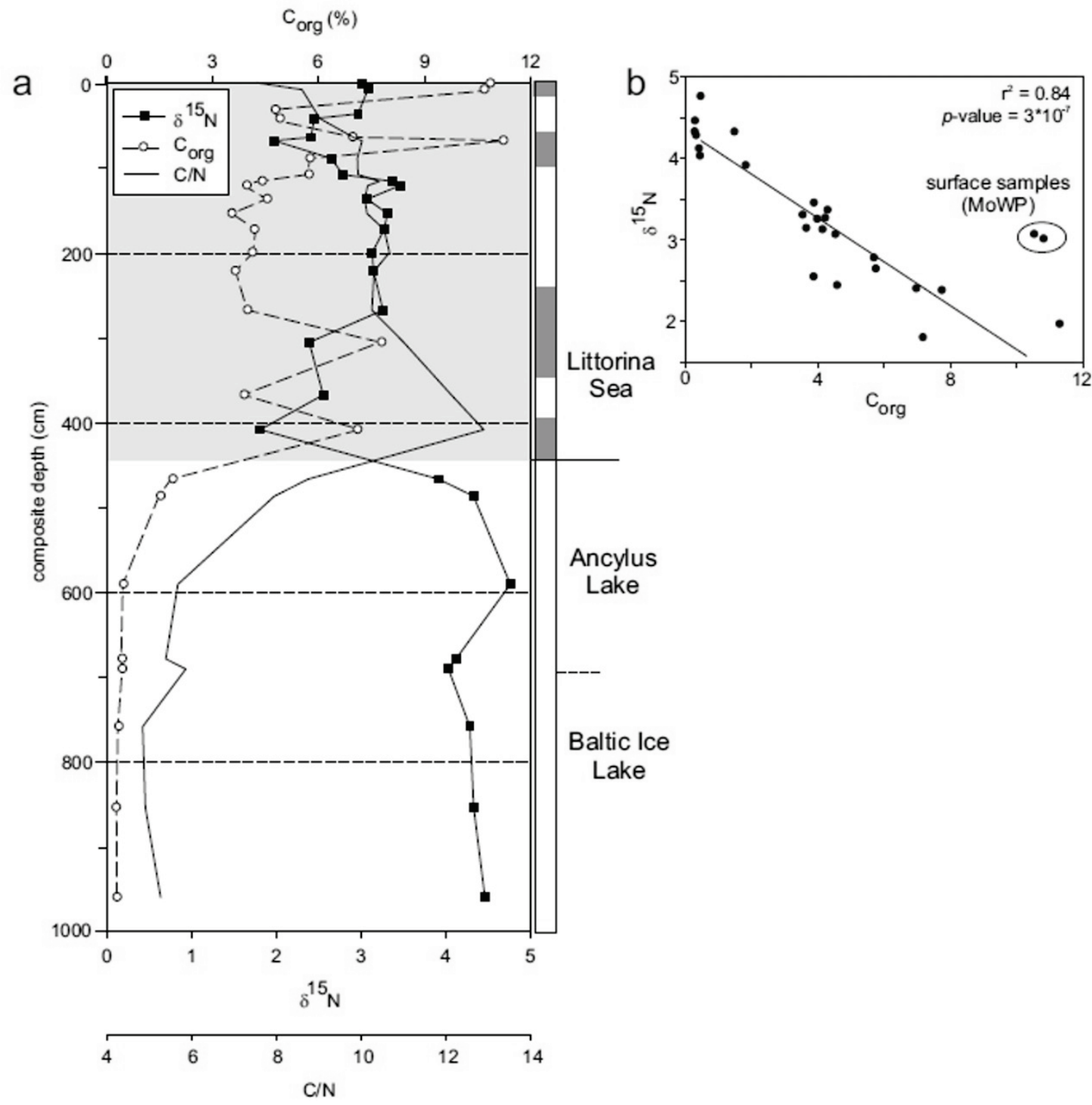

Fig. 3: a) Concentrations and distributions of bulk geochemical data $\left(\mathrm{C}_{\mathrm{org}}, \delta^{15} \mathrm{~N}\right.$, and $\left.\mathrm{C} / \mathrm{N}\right)$. Shaded areas in dark grey mark strongly laminated Littorina Sea sediment layers (see caption of Fig. 2). b) Cross plot of $\mathrm{C}_{\text {org }}$ with $\delta^{15} \mathrm{~N}$. Surface samples were excluded from the correlation. MoWP=Modern Warm Period.

\subsubsection{Biomarkers}

Figure 4 shows concentrations of selected biomarkers in the Gotland Deep sediments. Highest abundances of nonacosane $(n C 29)$ were found in Baltic Ice Lake 

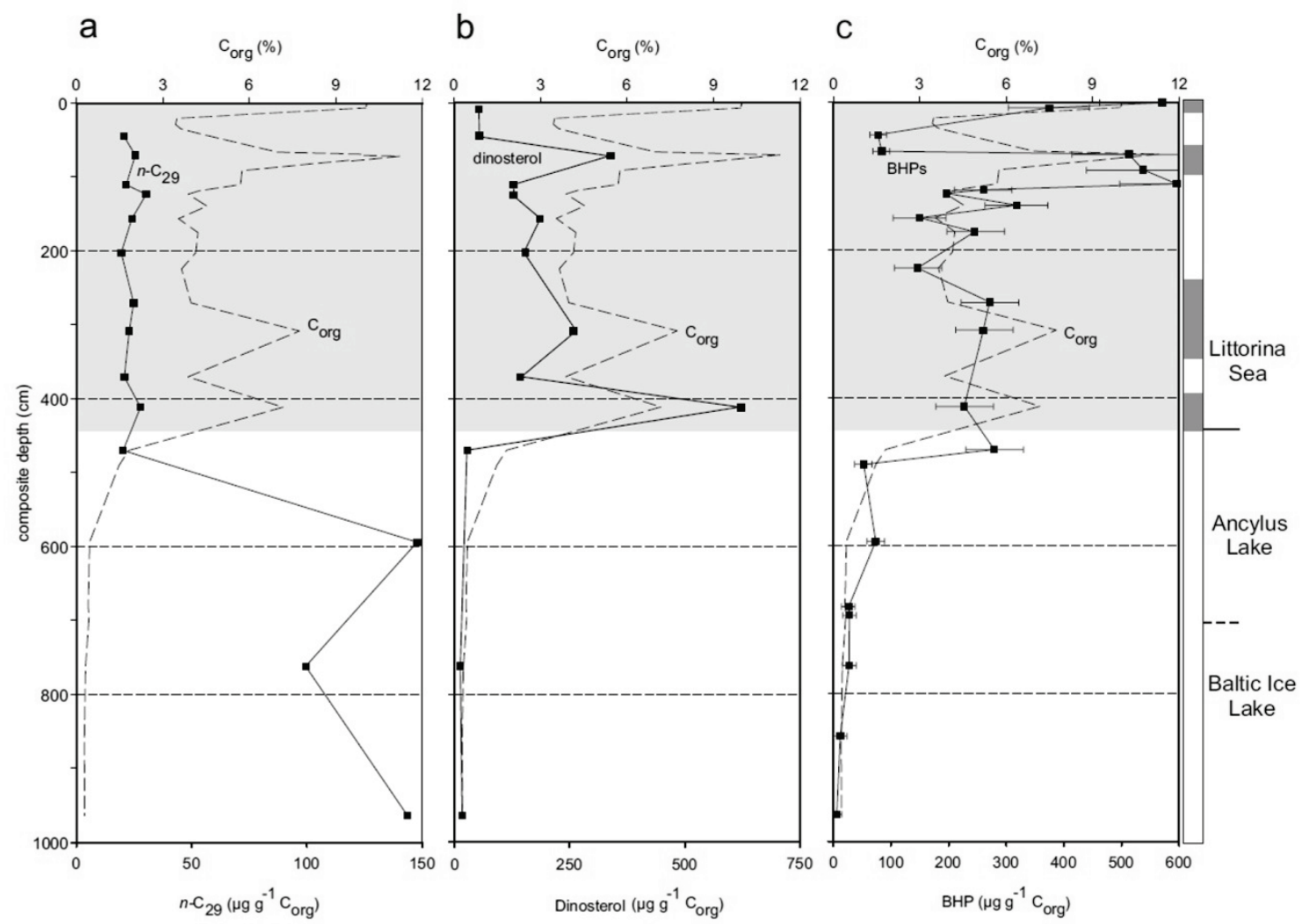

Fig. 4: Selected biomarkers in the Holocene sediments of the Gotland Deep in comparison with $C_{\text {org }}$. a) Nonacosane ( $n \mathrm{C} 29)$, representing higher plant inputs; b) dinosterol $(4 \alpha, 23,24$-trimethyl-5 $\alpha$-cholest22E-en-3 $\beta$-ol), representing dinoflagellate inputs; c) total BHP, representing inputs from hopanoidproducing bacteria. Error bars show the analytical uncertainty of BHP analyses of $20 \%$. Shaded areas in dark grey mark strongly laminated Littorina Sea sediment layers. BHP concentrations for the surface sediment samples (0-2 and 6-8 cmbsf) were taken from Berndmeyer et al. (2013).

and Ancylus Lake samples ( $\sim 600$ to $1000 \mathrm{cmbsf}$; up to $150 \mu \mathrm{g} \mathrm{g}^{-1} \mathrm{C}_{\text {org }}$, Fig. 4a). All core samples revealed a high carbon preference index (CPI) of $>5$, reflecting a strong odd-over-even carbon number predominance and thus a mostly terrestrial origin of $n$ C29 and other long-chain $n$-alkanes (Bray and Evans, 1961). Above the Ancylus Lake-Littorina Sea transition, concentrations clearly decreased to about $20 \mu \mathrm{g} \mathrm{g}^{-1}$ $\mathrm{C}_{\text {org. }}$ In the Littorina Sea sediments, concentrations of $n \mathrm{C} 29$ were relatively stable, demonstrating low fluctuations of terrestrial plant input. In contrast to $n \mathrm{C} 29$, abundances of dinosterol ( $4 \alpha, 23,24$-trimethyl-5 $\alpha$-cholest-22E-en-3 $\beta$-ol), a 4-methyl steroid prominent in dinoflagellates (Withers, 1983), is positively correlated with total $\mathrm{C}_{\text {org }}$ (Fig. 4b).

Similar to dinosterol, the sum of bacteriohopanepolyols (BHPs) revealed highest abundances in the Littorina Sea sediments. Within this lithological unit, particularly high BHP amounts, maximising at about $600 \mu \mathrm{g} \mathrm{g}^{-1} \mathrm{C}_{\mathrm{org}}$, were observed in the most 
organic-rich layers. Whereas dinosterol increased at the establishment of the Littorina Sea stage, BHPs had already risen during the late Ancylus Lake stage (after the initial Littorina transgression at about $470 \mathrm{cmbsf}$ ). The lowest BHP concentrations were observed in the earlier Ancylus Lake and Baltic Ice Lake sediments. The Gotland Deep core contains eight distinct BHPs whose individual distributions are shown in Fig. 5. Highest amounts were found for bacteriohopanetetrol (BHT) and 32,35-anhydroBHT, with the latter showing greater abundances with increasing depth. 35-aminobacteriohopanetriol and -tetrol were prominent in sediments representing the beginning of the Littorina Sea stage. BHT cyclitol ethers (two isomers; tentatively identified by co-elutions with previously identified BHT cyclitol isomers) were first observed in sediments of the late Ancylus Lake stage and were omnipresent, although in low abundance, in the sediments of the Littorina Sea. In the lowermost Littorina Sea stage sample studied (at 420 cmbsf), an unknown BHT isomer was found, whose elution characteristics correspond with a BHT isomer found in the recent Gotland Deep water column (Berndmeyer et al., 2013).

\subsection{Discussion}

\subsubsection{Biogeochemical changes in the Holocene as reflected by bulk geochemical parameters}

The sediments from the Gotland Deep markedly reflect the establishment of the marine-brackish Littorina Sea in a steep increase in $\mathrm{C}_{\text {org, }}$ probably due to enhanced preservation and/or increasing primary production, and the deposition of strongly laminated sediments (Fig. 2; see discussion below). A peak in $\mathrm{C}_{\text {org }}$ was also observed at about $800 \mathrm{yr}$ BP, most likely reflecting high organic carbon accumulation and sediment lamination during the MCA. The sediments deposited during the subsequent cooler period (Little Ice Age; LIA) are characterised by low $\mathrm{C}_{\text {org }}$ and most likely oxic conditions in the bottom waters (Sohlenius et al., 1996; Andrén et al., 2000b; Fig. 2). Above, the MoWP and recent anthropogenic influence are reflected by a parallel increase in $\delta^{15} \mathrm{~N}$ and $\mathrm{C}_{\text {org }}$ (Voss et al., 2001; Struck et al., 2000). Except for the samples from the MoWP, Corg correlates negatively with bulk $\delta^{15} \mathrm{~N}$ (Fig. 3). Enhanced growth of cyanobacteria capable of biological nitrogen fixation is a 

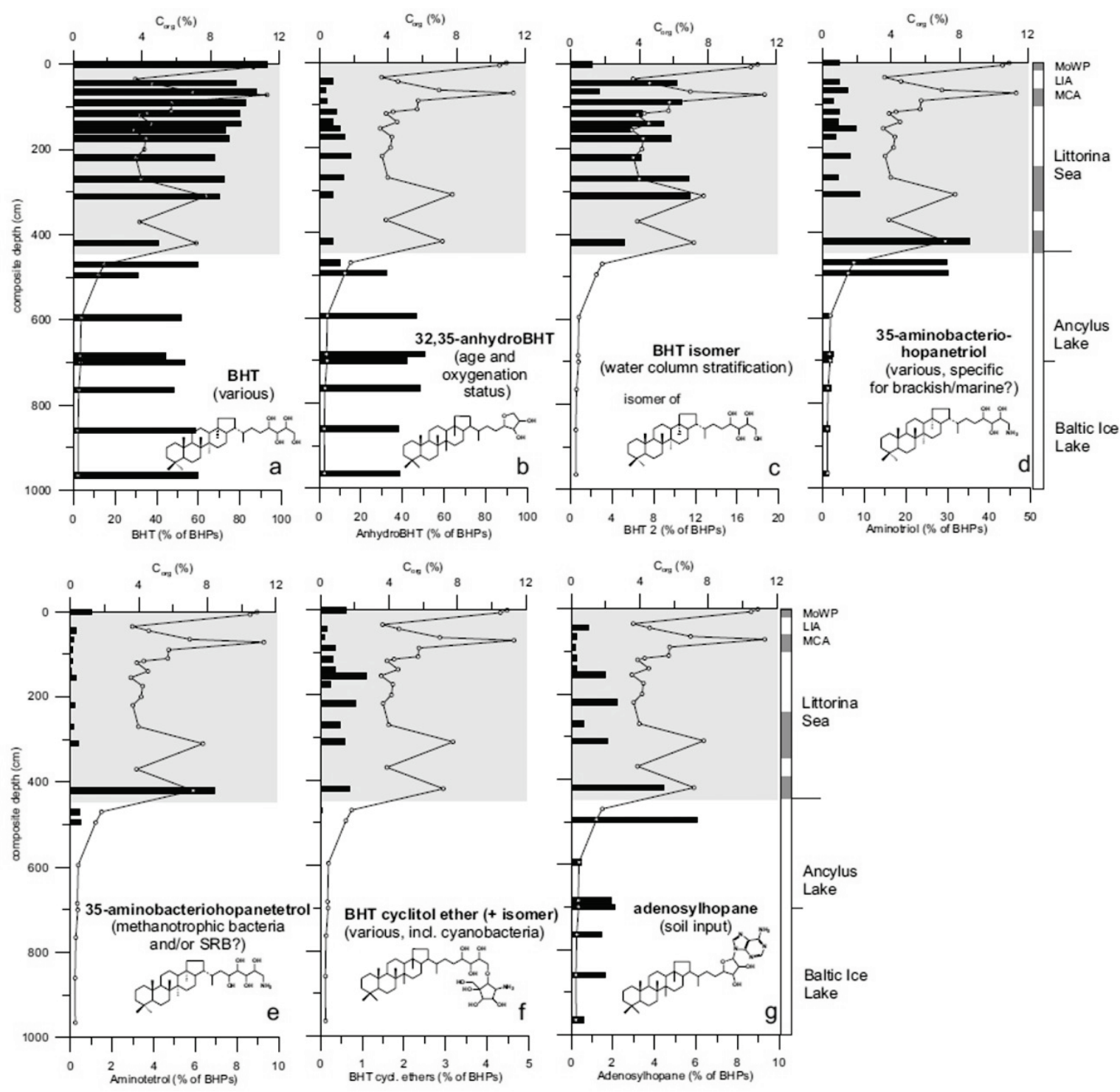

Fig. 5: Distributions of major BHPs. Note different $y$-axes for individual BHPs; MoWP=Modern Warm Period; LIA=Little Ice Age; MCA=Medieval Climate Anomaly. Shaded areas in dark grey mark strongly laminated Littorina Sea sediment layers.

plausible explanation for low $\delta^{15} \mathrm{~N}$ values, a scenario which has been suggested for numerous settings (Sachs and Repeta, 1999; Kuypers et al., 2004; Blumenberg et al., 2009), including the Baltic Sea (Bianchi et al., 2000; Voss et al., 2001; Voss, 2005). The increasing importance of nitrogen fixing cyanobacteria after the Littorina Sea transgression is demonstrated by enhanced occurrences of cyanobacterial carotenoid pigments and molybdenum, which is an essential micronutrient to facilitate nitrogen fixation (Poutanen and Nikkila, 2001; Kunzendorf et al., 2001; Borgendahl et al., 2007). Today, cyanobacteria contribute about $45 \%$ to the bulk sedimentary nitrogen (Struck et al., 2004). Flourishing of nitrogen-fixing 
(cyano)bacteria is commonly promoted by phosphorus excess (lowering N/P ratios) through riverine input or release from anoxic sediments (Bianchi et al., 2000). Consequently, the establishment of a stratified, partly anoxic water body after the Littorina Sea transgression is a conceivable scenario for a decrease of N/P ratios and an increase in cyanobacterial biomass. A further reduction in the N/P ratio may have been induced by bacterial denitrification under the established anoxic conditions (Haug et al., 1998; Struck et al., 2000). Due to the high energy costs of cleaving $\mathrm{N}_{2}$, nitrogen-fixing cyanobacteria have only an advantage over algae in waters depleted in bioavailable nitrogen (Karl et al., 2002). Hence, the good correlation between high $\mathrm{C}_{\text {org }}$ and low $\delta^{15} \mathrm{~N}$ argues for (i) a major role of nitrogen-fixing (cyano)bacteria during the deposition of organic-rich, laminated sediments (e.g. after the Littorina Sea transgression, and during the MCA), and for (ii) enhanced primary production under N/P ratios lower than the Redfield Ratio (C/N/P: 106/16/1; (Redfield et al., 1963)). At the same time, cyanobacteria are known for biomass $\mathrm{C} / \mathrm{N}$ ratios higher than that obtained from the Redfield Ratio $(\mathrm{C} / \mathrm{N}=6.6)$. For Nodularia spumigena, an important (nitrogen-fixing) cyanobacterium in the central Baltic Sea, a C/N of 8.5 was reported (Sörensson and Sahlsten, 1987). Consequently, the observed increase in $\mathrm{C} / \mathrm{N}$ in laminated sediments after the Littorina Transgression (Fig. 3a) is well explainable with an increasing importance of cyanobacteria among the primaryproducing community. Moreover, a direct temperature dependence of cyanobacterial blooming in the central Baltic Sea has also currently been reported (Kabel et al., 2012), in addition to the indirect role of high temperatures for water column stratification, and the related shift to low N/P ratios.

\subsubsection{Biomarker records of biogeochemical perturbations in the central Baltic Sea}

6.6.2.1 Baltic Ice Lake-Ancylus Lake transition (10 700 - 9800 yr BP)

The resolution of samples from these intervals was low, but among the studied biomarkers the transition is not reflected in any changes.

\subsubsection{Ancylus Lake-Littorina Sea transition ( 8500 - 8000 yr BP)}

In Ancylus Lake sediments, nonacosane $(n \mathrm{C} 29)$ was much higher in relative abundance than in Littorina Sea deposits (Fig. 4a). $n$ C29 is a biomarker for higher 
plant waxes (Eglinton et al., 1962), and the concentration in the lower core demonstrates the high relevance of allochthonous input during the Ancylus Lake stage. This is supported by previous findings of abundant plant-derived triterpane biomarkers in Ancylus Lake sediments (Nytoft and Larsen, 2001). After the Littorina Sea transgression, a substantial environmental change is reflected by a drop in $n \mathrm{C} 29$ abundance by an order of magnitude (Fig. 4a). At the same time, a biomarker for dinoflagellates, dinosterol (Withers, 1983), increased (Fig. 4b). Together, both biomarkers mirror the shift from an oligotrophic, terrestrially influenced system towards a setting controlled by particular brackish-marine primary producers, which fits well with micropalaeontological studies (e.g. Brenner, 2001). It must be noted, however, that dinosterol contributions in the Gotland Deep sediments appear to be largely due to marine dinoflagellates of the Littorina Sea stage, whereas the high relevance of specific freshwater dinoflagellates (e.g. Gonyaulax apiculata) reported for the Ancylus Lake stage (Brenner, 2001; Yu and Berglund, 2007) is not reflected by this biomarker.

As a result of the Littorina Sea transgression, concentrations of BHPs increased by almost two orders of magnitude and followed a similar trend to $\mathrm{C}_{\text {org }}$ (Fig. 4c). The maximum BHP concentrations of up to $600 \mu \mathrm{g} \mathrm{g}^{-1} \mathrm{C}_{\text {org }}$ were extraordinarily high compared to other marine settings (e.g. four times higher than in Black Sea sediments; Blumenberg et al., 2009). Similarly, diploptene, a hopanoid hydrocarbon that is produced by many bacteria along with BHP, was reported to be most abundant in the Littorina Sea stage in Gotland Deep sediments (Nytoft and Larsen, 2001). The consistently low amounts of adenosylhopane, a BHP abundant in soil bacteria (Talbot and Farrimond, 2007; Cooke et al., 2008; Fig. 5g), argues against variations in land-derived allochthonous BHP contributions as a major control on BHP patterns. Likewise, the peak in adenosylhopane in the late Ancylus Lake stage may be due to enhanced input of soil organic matter during the flooding of land areas during the Littorina transgression (Fig. 5g).

The observed trends might be also influenced, or amplified, by enhanced lipid preservation as result of the establishment of anoxic bottom waters and sediments. Enhanced preservation is crucial for high BHP abundances in sediments as these polyfunctionalised lipid structures are prone to microbial degradation. A change in the redox environment in the course of the Littorina Sea transgression is reflected in 
a decrease in the relative abundance of 32,35-anhydroBHT (Fig. 5b). 32,35anhydroBHT is a diagenetic degradation product of BHT and composite BHPs under acidic and marine sedimentary conditions (Bednarczyk et al., 2005; Schaeffer et al., 2008,2010 ). Higher concentrations of this diagenetic product consequently suggest a lower preservation potential in Ancylus Lake and older sediments. In turn, the generally low amounts of 32,35-anhydroBHT in Littorina Sea deposits, with lowest abundances recorded in the organic rich laminated sediments, may reflect a different preservational status of BHP. Apart from that, however, it is unlikely that total BHP concentrations, including the diagenetic product 32,35-anhydroBHT, are controlled by redox changes in bottom waters and sediments. Studies from comparable settings demonstrated a stability of BHPs up to an age of $100000 \mathrm{yr}$ (Cooke et al., 2008; Coolen et al., 2008; Blumenberg et al., 2009, 2010). Providing additional evidence for production of BHPs as key control for BHP abundances in the studied core, $C_{\text {org }}$ trends were found to be slightly delayed to BHPs (e.g. AncylusLittorina transition or at the MCA; Fig. 4). This rather indicates BHPs to record pioneer organisms of these changes.

BHPs specific for cyanobacteria were not found in the Gotland Deep sediments. However, an isomer of the common BHT cyclitol ether was observed that was also observed in the oxic part of the water column (Berndmeyer et al., 2013), which suggests a bacterial source from within the euphotic zone (Fig. 5f; BHT cyclitol ether were summed up as similar trend suggest the same origin). An isomer of the common BHT cyclitol ether was also reported from the cyanobacterium Anacystis montana (Herrmann et al., 1996), which has, however, not been reported from the recent Baltic Sea water column. The contribution of cyanobacteria to the sedimentary BHP pool in Gotland Deep sediments therefore remains ambiguous and seemingly reflects the fact that neither all cyanobacteria produce BHPs nor that their BHP inventory, if present, must always be specific.

\subsubsection{Biogeochemical variations during the Littorina Sea stage as reflected by BHPS}

Despite the generally higher importance of BHP producing bacteria in the Littorina Sea stage, internal variations in this unit were also observed. 35aminobacteriohopanetriol is, along with BHT, a ubiquitous BHP and is produced by diverse bacterial groups. Bacteria rich in 35-aminobacteriohopanetriol flourished 
particularly during the transition from the Ancylus Lake to the Littorina Sea where concentrations are about 4-fold higher than in all other samples studied (Fig. 5d). Which group of bacteria particularly sourced 35-aminobacteriohopanetriol is unclear, but the same maximum, at the time of the Littorina Sea transgression is revealed by a more specific BHP, 35-aminobacteriohopanetetrol (Fig. 5e), which was also particularly abundant in Black Sea sediments reflecting the marine ingression after the last deglaciation (Blumenberg et al., 2009). 35-aminobacteriohopanetetrol was reported from cultured methanotrophic bacteria (Neunlist and Rohmer, 1985; Talbot et al., 2001) as well as from sulfate reducing bacteria (Blumenberg et al., 2006, 2012). Indeed, both bacterial groups can plausibly explain the observed trend in these individual BHP concentrations. First, the inflow of marine sulfate-rich waters during the Littorina Sea transgression, and the establishment of a stratified water column has likely strongly stimulated the activity of sulfate reducing bacteria in the upper sediments and bottom waters. Increased microbial sulfate reduction is also expressed by an increase in pyrite sulfur in the respective core section (data not shown; see also black pyrite layers from downward-diffusing $\mathrm{H}_{2} \mathrm{~S}$ in the uppermost Ancylus Lake sediments; Fig. 2). However, during the Littorina stage, SRB should have remained a stable part of the microbial community. This conflicts with the observed decreases in 35-aminobacteriohopanetriol and -tetrol abundances after the Littorina optimum (Fig. 5d and e). Moreover, a quantitative estimate on sedimentary SRB in a comparable sedimentary setting (the Black Sea), clearly argued against these bacteria as considerable contributor to the BHP pool in this setting (Blumenberg et al., 2009). Another possible source for both BHPs are methanotrophic bacteria, which were reported as important members of the microbial community at the recent redoxcline of the Gotland Deep water column (Schmale et al., 2012; Berndmeyer et al., 2013). Unfortunately, the analyses of $\delta^{13} \mathrm{C}$ values to characterise the bacterial source (Hayes, 1993) and particularly to identify methanotrophy (Freeman et al., 1990) were not possible for the Gotland Deep due to low concentrations. Despite this, we propose that both 35-aminobacteriohopanetriol and -tetrol are related to pioneer methanotrophic bacteria related to the establishment of the pelagic redoxcline.

Redoxcline processes are also reflected by another abundant BHP in Gotland Deep sediments. In the upper part of the core, we found relatively high amounts of a BHT 
isomer (Fig. 5c). The nature of the isomerisation was not further identified, but a BHT isomer was observed to be abundant in suboxic zones of stratified marine water columns (Sáenz et al., 2011) and near the redoxcline of a microbial mat (Blumenberg et al., 2013), and a compound with the same spectral and chromatographic properties was also reported from the redoxcline of the modern Gotland Deep water column (Berndmeyer et al., 2013).We therefore suggest that the consistent occurrence of the BHT isomer in the underlying sediments of the Littorina Sea stage records water column stratification. It appears, however, that the concentrations of this compound cannot directly be translated into the stability of the stratification because neither the strongly laminated sediments of the MCA and MoWP warm periods (intense stratification) nor the sediments of the LIA (less pronounced stratification; Zillén and Conley, 2010) show corresponding excursions in the relative abundance of the BHT isomer (Fig. 5c). Further studies are needed to corroborate the relationship of BHT isomer occurrences to redoxcline processes, as well as the identification of the biological source(s).

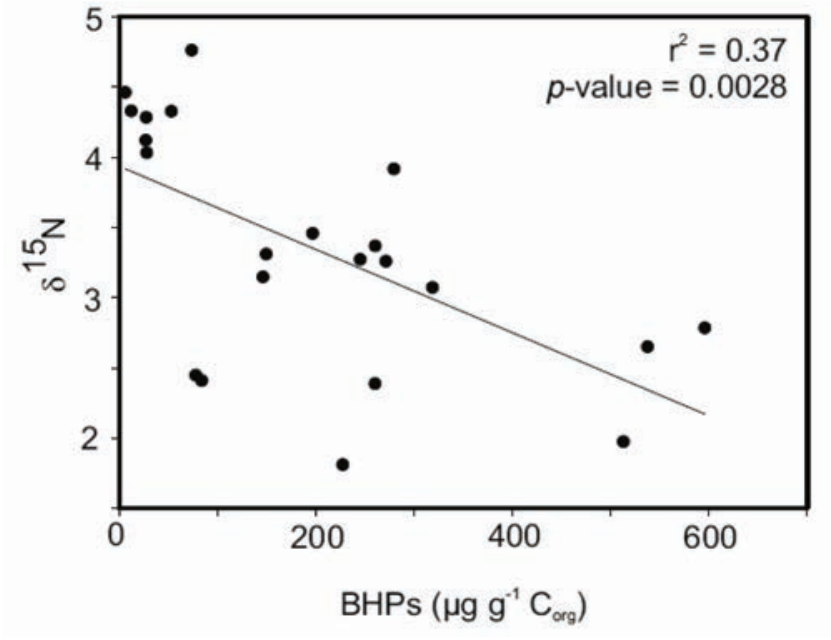

Fig. 6: Cross plot of BHP abundances with bulk $\delta^{15} \mathrm{~N}$.
Apart from the ups and downs of individual BHP sources, it can be stated that the overall input of hopanoids is linked to changes in the nutrient situation (low N/P ratios with high phosphorus loads; Bianchi et al., 2000) and the establishment of water column stratification. A similar scenario may explain BHP increases in Black Sea sediments as a result of the ingression of Mediterranean waters through the Bosporus after the Last Glacial Maximum (Blumenberg et al., 2009). The correlation between the occurrence of laminated sediments, bulk $\delta^{15} \mathrm{~N}$ and total BHPs may be taken as support for a similar relationship for the Baltic Sea (Fig. 6), but may also be linked to the development of redoxclines and the establishment of redoxcline-specific BHP producing bacteria (Wakeham et al., 2007; Sáenz et al., 2011; Berndmeyer et al., 2013; Blumenberg et al., 2013). For the Gotland Deep sediments it is likely that both bacterial primary 
production under low N/P ratios and the presence of a redoxcline controlled BHP abundances, but which factor prevailed is unclear. Nevertheless, the stability of the stratification is most likely an important factor as BHP abundances appear to be exceedingly high during warmer times (e.g. during the MCA and the MoWP). Future studies should focus on the identification of microbial BHP producers thriving at these biogeochemical zones because these zones appear to be key environments for the biosynthesis of the precursors of geohopanoids, which are ubiquitous in rocks, oils and sediments.

\subsection{Conclusions}

A composite core (gravity core and Frahmlot) covering the last $9000 \mathrm{yr}$ of the central Baltic Sea history was studied for bulk geochemical parameters and selected biomarkers, with a particular focus on bacteriohopanepolyols (BHPs). Biomarker distributions and abundances in the Baltic Ice Lake (before $11700 \mathrm{yr}$ BP) and Ancylus Lake (10 700 to $8500 \mathrm{yr}$ BP) sediments were similar and reflect pronounced higher plant inputs and low primary productivity. Marine dinoflagellates, as indicated by dinosterol, and BHP producing bacteria began to flourish after the Littorina Sea transgression 8500 to 8000 yr BP. In the Littorina Sea stage, BHP concentrations are the highest so far reported from a marine or brackish setting. BHPs are most abundant in laminated sediments, pointing at an important role of hopanoid producing bacteria during times of water column stratification and pronounced anoxia of the lower water column. Such conditions characterised, for instance, the onset of the Littorina Sea transgression, the MCA and the MoWP. Whereas the discrete microorganisms that sourced the BHPs in Gotland Deep sediments still have to be identified, the structures and distributions of individual BHPs point at contributions from methanotrophic and other bacteria specific to redoxclines, as well as most likely cyanobacteria. A good correlation between BHPs, $\mathrm{C}_{\text {org }}$ and $\delta^{15} \mathrm{~N}$ highlights an involvement of BHP-producing bacteria in the fixation of atmospheric nitrogen and, as this process is crucial for the present day Baltic Sea, underpins their role for the entire nutrient cycle in this marginal marine basin.

\section{Acknowledgments}

We thank the officer and crew of RV Merian (MSM 16-1) for excellent collaboration during field work. T. Leipe, R. Endler, and H. Arz (all IOW) are acknowledged for 
helpful discussion. Two anonymous reviewers are thanked for their helpful comments. We thank J. Dyckmans (Centre for Stable Isotope Research and Analysis, University of Göttingen) for help with stable nitrogen isotope analysis. C. Conradt (University of Göttingen) is kindly acknowledged for laboratory assistance. The study was supported by the Deutsche Forschungsgemeinschaft (DFG) through projects BL 971/1-3 and BL 971/3-1.

This Open Access Publication is funded by the University of Göttingen.

\section{References}

Andrén, E., Andrén, T., Sohlenius, G., 2000a. The Holocene history of the southwestern Baltic Sea as reflected in a sediment core from the Bornholm Basin. Boreas 29, 233-250.

Andrén, E., Andrén, T., Kunzendorf, H., 200b. Holocene history of the Baltic Sea as a background for assessing records of human impact in the sediments of the Gotland Basin. The Holocene 10, 687-702.

Andrén, T., Björck, S., Andrén, E., Conley, D., Zillén, L., Anjar, J., 2011. Late Quaternary climate variations reflected in Baltic Sea sediments In: Harff, J., Björck, S., Hoth, P. (Eds). The Baltic Sea Basin. Springer, 449 pp., 75-97.

Bednarczyk, A., Carillo Hernandez, T., Schaeffer, P., Adam, P., Talbot, H. M., Farrimond, P., Riboulleau, A., Largeau, C., Derenne, S., Rohmer, M., Albrecht, P., 2005. 32,35- Anhydrobacteriohopanetetrol: an unusual bacteriohopanepolyol widespread in recent and past environments. Organic Geochemistry 36, 673-677.

Bennike, O., Jensen, J. B., Lemke, W., Kuijpers, A., Lomholt, S., 2004. Late- and postglacial history of the Great Belt, Denmark, Boreas, 33, 18-33, 2004.

Berndmeyer, C., Thiel, V., Schmale, O., Blumenberg, M., 2013. Biomarkers for aerobic methanotrophy in the water column of the stratified Gotland Deep (Baltic Sea). Organic Geochemistry 55, 103-111, 2013. 
Bianchi, T. S., Engelhaupt, E., Westman, P., Andr'en, T., Rolff, C., Ragnar, E., 2000. Cyanobacterial blooms in the Baltic Sea: Natural or human-induced? Limnology Oceanography 45, 716-726.

Blumenberg, M., Krüger, M., Nauhaus, K., Talbot, H. M., Oppermann, B., Seifert, R., Pape, T., Michaelis, W., 2006. Biosynthesis of hopanoids by sulfate-reducing bacteria (genus Desulfovibrio), Environmental Microbiology 8, 1220-1227.

Blumenberg, M., Seifert, R., Kasten, S., Bahlmann, E., Michaelis, W., 2009. Euphotic zone bacterioplankton sources major sedimentary bacteriohopanepolyols in the Holocene Black Sea. Geochimica et Cosmochimica Acta, 73, 750-766.

Blumenberg, M., Mollenhauer, G., Zabel, M., Reimer, A., Thiel, V., 2010. Decoupling of bio- and geohopanoids in sediments of the Benguela Upwelling System (BUS). Organic Geochemistry 41, 1119-1129.

Blumenberg, M., Hoppert, M., Krüger, M., Dreier, A., Thiel, V., 2012. Novel findings on hopanoid occurrences among sulfate reducing bacteria: is there a direct link to nitrogen fixation? Organic Geochemistry 49, 1-5.

Blumenberg, M., Arp, G., Reitner, J., Schneider, D., Daniel, R., Thiel, V., 2013. Bacteriohopanepolyols in a stratified cyanobacterial mat from Kiritimati (Christmas Island, Kiribati), Organic Geochemistry 55, 55-62.

Boesen, C. and Postma, D., 1988. Pyrite formation in anoxic environments of the Baltic. American Journal of Science 288, 575-603.

Borgendahl, J. and Westman, P., 2007. Cyanobacteria as a trigger for increased primary productivity during sapropel formation in the Baltic Sea - a study of the Ancylus/Littorina transition. Journal of Paleolimnology 38, 1-12.

Bray, E. E. and Evans, E. D., 1961. Distribution of $n$-paraffins as a clue to recognition of source beds. Geochimica et Cosmochimica Acta 22, 2-15.

Brenner, W.W., 2001. Organic-walled microfossils from the central Baltic Sea, indicators of environmental change and base for ecostratigraphic correlation. Baltica $14,40-51$. 
Brenner, W., 2005. Holocene environmental history of the Gotland Basin (Baltic Sea) - a micropalaeontological model. Palaeogeography Palaeoclimatology Palaeoecology 220, 227-241.

Cooke, M. P., Talbot, H. M., Wagner, T., 2008. Tracking soil organic carbon transport to continental margin sediments using soil-specific hopanoid biomarkers: a case study from the Congo fan (ODP site 1075). Organic Geochemistry 39, 965-971.

Coolen, M. J. L., Talbot, H. M., Abbas, B. A., Ward, C., Schouten, S., Volkman, J. K., Sinninghe Damsté, J. S., 2008. Sources for sedimentary bacteriohopanepolyols as revealed by $16 \mathrm{~S}$ rDNA stratigraphy. Environmental Microbiology 10, 1783-1803.

Eglinton, G., Hamilton, R. J., Raphael, R. A., Gonzales, A. G., 1962. Hydrocarbon constituents of the wax coatings of plant leaves: A taxonomic study. Nature 193, 739-742.

Freeman, K. H., Hayes, J. M., Trendel, J.-M., Albrecht, P., 1990. Evidence from carbon isotope measurements for diverse origins of sedimentary hydrocarbons. Nature 343, 254-256.

Haug, G. H., Pedersen, T. F., Sigman, D. M., Calvert, S. E., Nielsen, B., Peterson, L. C., 1998. Glacial/interglacial variations in production and nitrogen fixation in the Cariaco Basin during the last 580 kyr. Paleoceanography 13, 427.

Hayes, J. M., 1993. Factors controlling ${ }^{13} \mathrm{C}$ contents of sedimentary organic compounds: Principles and evidence. Marine Geology 113, 115-125.

Herrmann, D., Bisseret, P., Connan, J., Rohmer, M., 1996. Relative configurations of carbapseudopentose moieties of hopanoids of the bacterium Zymomonas mobilis and the cyanobacterium "Anacystis montana". Tetrahedron Letters 37, 1791-1794.

Kabel, K., Moros, M., Porsche, C., Neumann, T., Adolphi, F., Andersen, T.J., Siegel, H., Gerth, M., Leipe, T., Jansen, E., Sinninghe Damsté, J.S., 2012. Impact of climate change on the Baltic Sea ecosystem over the past 1000 years. Nature Climate Change 2, 871847. 
Karl, D., Michaels, A., Bergman, B., Capone, D., Carpenter, E., Letelier, R., Lipschultz, F., Paerl, H., Sigman, D., Stal, L., 2002. Dinitrogen fixation in the world's oceans. Biogeochemistry 57/58, 47-98.

Kunzendorf, H., Voss, M., Brenner, W., Andrén, T., Vallius, H., 2001. Molybdenum in sediments of the central Baltic Sea as an indicator for algal blooms. Baltica 14,123130.

Kuypers, M.M.M., van Breugel, Y., Schouten, S., Erba, E., Sinninghe Damsté, J.S., 2004. $\mathrm{N}_{2}$-fixing cyanobacteria supplied nutrient $\mathrm{N}$ for Cretaceous oceanic anoxic events. Geology 32, 853-856.

Labrenz, M., Jost, G., Jürgens, K., 2007. Distribution and abundant prokaryotic organisms in the water column of the central Baltic Sea with an oxic-anoxic interface. Aquatic Microbial Ecology 46, 177-190.

Leipe, T., Tauber, F., Vallius, H., Virtasalo, J., Uścinowicz, S., Kowalski, N., Hille, S., Lindgren, S., Myllyvirta, T., 2010. Particulate organic carbon (POC) in surface sediments of the Baltic Sea. Geo-Marine Letters 31, 175-188.

Lougheed, B.C., Snowball, I., Moros, M., Kabel, K., Muschelera, R., Virtasalo, J.J., Wacker, L., 2012. Using an independent geochronology based on palaeomagnetic secular variation (PSV) and atmospheric $\mathrm{Pb}$ deposition to date Baltic Sea sediments and infer ${ }^{14} \mathrm{C}$ reservoir age. Quaternary Science Reviews 42, 43-58.

Moros, M., Lemke, W., Kuijpers, A., Endler, R., Jensen, J.B., Bennike, O., Gingele, F., 2002. Regressions and transgressions of the Baltic basin reflected by a new highresolution deglacial and postglacial lithostratigraphy for Arkona Basin sediments (western Baltic Sea). Boreas 31 151-162.

Nausch, M., Nausch, G., Lass, H. U., Mohrholz, V., Nagel, K., Siegel, H., Wasmund, N., 2009. Phosphorus input by upwelling in the eastern Gotland Basin (Baltic Sea) in summer and its effects on filamentous cyanobacteria. Estuarine, Coastal and Shelf Sciences 83, 434-442, 2009. 
Neunlist, S., and Rohmer, M., 1985. Novel hopanoids from the methylotrophic bacteria Methylococcus capsulatus and Methylomonas methanica. Biochemical Journal 231, 635-639.

Nytoft, H. P. and Larsen, B., 2001. Triterpenoids and other organic compounds as markers of depositional conditions in the Baltic Sea deep basins during the Holocene. Baltica 14, 95-107.

Poutanen, E.-L. and Nikkila, K., 2001. Carotenoid pigments as tracers of cyanobacterial blooms in recent and postglacial sediments of the Baltic Sea. Ambio 30, 179-183.

Redfield, A. C., Ketchum, B. H., Richards, F. A., 1963. The influence of organisms on the composition of sea-water. In: Hill, N. (Ed.). The Sea 2. Interscience, New York, 26-77.

Reissmann, J. H., Burchard, H., Feistel, R., Hagen, E., Lass, H. U., Mohrholz, V., Nausch, G., Umlauf, L., Wieczorek, G., 2009. Vertical mixing in the Baltic Sea and consequences for eutrophication - A review. Progress in Oceanography 82, 47-80.

Rößler, D., Moros, M., Lemke, W., 2011. The Littorina transgression in the southwestern Baltic Sea: new insights based on proxy methods and radiocarbon dating of sediment cores. Boreas 40, 231-241.

Sachs, J.P. and Repeta, D.J., 1999. Oligotrophy and Nitrogen Fixation During Eastern Mediterranean Sapropel Events. Science 286, 2485-2488.

Sáenz, J. P., Wakeham, S. G., Eglinton, T. I., Summons, R. E., 2011. New constraints on the provenance of hopanoids in the marine geologic record: Bacteriohopanepolyols in marine suboxic and anoxic environments. Organic Geochemistry 42, 1351-1362.

Schaeffer, P., Schmitt, G., Adam, P., Rohmer, M., 2008. Acidcatalyzed formation of 32,35-anhydrobacteriohopanetetrol from bacteriohopanetetrol, Organic Geochemistry 39, 1479-1482. 
Schaeffer, P., Schmitt, G., Adam, P., Rohmer, M., 2010. Abiotic formation of 32,35anhydrobacteriohopanetetrol: A geomimetic approach. Organic Geochemistry 41, 1005-1008.

Schmale, O., Schneider von Deimling, J., Gülzow, W., Nausch, G., Waniek, J. J., Rehder, G., 2010. Distribution of methane in the water column of the Baltic Sea. Geophysical Research Letters 37, L12604.

Schmale, O., Blumenberg, M., Kießlich, K., Jakobs, G., Berndmeyer, C., Labrenz, M., Thiel, V., Rehder, G., 2012. Aerobic methanotrophy within the pelagic redox-zone of the Gotland Deep (central Baltic Sea). Biogeosciences 9, 4969-4977.

Sohlenius, G., Sternbeck, J., Andrén, E., Westman, P., 1996. Holocene history of the Baltic Sea as recorded in a sediment core from the Gotland Deep. Marine Geology 134, 183-201.

Sörensson, F. and Sahlsten, E., 1987. Nitrogen dynamics of a cyanobacteria bloom in the Baltic Sea: new versus regenerated production. Marine Ecology Progress Series $37,277-284$.

Struck, U., Emeis, K. C., Voss, M., Christiansen, C., Kunzendorf, H., 2000. Records of southern and central Baltic Sea eutrophication in $\delta^{13} \mathrm{C}$ and $\delta^{15} \mathrm{~N}$ of sedimentary organic matter. Marine Geology 164, 157-171.

Struck, U., Pollehne, F., Bauerfeind, E., v. Bodungen, B., 2004. Sources of nitrogen for the vertical particle flux in the Gotland Sea (Baltic Proper) - results from sediment trap studies. Journal of Marine Systems 45, 91-101.

Talbot, H. M. and Farrimond, P., 2007. Bacterial populations recorded in diverse sedimentary biohopanoid distributions Organic Geochemistry 38, 1212-1225.

Talbot, M., Watson, D.F., Murrell, J.C., Carter, J.F., Farrimond, P., 2001. Analysis of intact bacteriohopanepolyols from methanotrophic bacteria by reversed-phase highperformance liquid chromatography-atmopheric pressure chemical ionisation mass spectrometry. Journal of Chromatography A, 921, 175-185. 
Taylor, K. A. and Harvey, R. H., 2001. Bacterial hopanoids as tracers of organic carbon sources and processing across the western Arctic continental shelf. Organic Geochemistry 42, 487-497.

Voss, M., 2005. Nitrogen cycle of the Baltic Sea from an isotopic perspective. Global Biogeochemical Cycles 19, GB3001.

Voss, M., Kowalewska, G., Brenner, W., 2001. Microfossil and biogeochemical indicators of environmental changes in the Gotland Deep during the last 10000 years. Baltica 14, 131-140.

Wakeham, S. G., Amann, R., Freeman, K. H., Hopmans, E. C., Joergensen, B. B., Putnam, I. F., Schouten, S., Sinninghe Damsté, J. S., Talbot, H. M., Woebken, D., 2000. Microbial eoclogy of the stratified water column of the Black Sea as revealed by a comprehensive biomarker study. Organic Geochemistry 38, 2070-2097.

Wasmund, N., Nausch, G., Voss, M., 2012. Upwelling events may cause cyanobacteria blooms in the Baltic Sea. Journal of Marine Systems 90, 67-76.

Withers, N., 1983. Dinoflagellates sterols. In: Scheuer, P. J. (Ed.). Marine Natural Products. Chemical and Biological Perspectives, Academic Press, New York, 87-130.

Yu, S.-Y. and Berglund, B. E., 2007. A dinoflagellate cyst record of Holocene climate and hydrological changes along the southeastern Swedish Baltic coast, Quaternary Research 67, 215-224.

Zillén, L. and Conley, D. J., 2010. Hypoxia and cyanobacteria blooms - are they really natural features of the late Holocene history of the Baltic Sea?. Biogeosciences 7, $2567-2580$. 


\section{7}

\section{Summary and conclusions}

The results presented in this thesis are parts of the multidisciplinary project "Aerobic and anaerobic methane consumption in the central Baltic Sea water column" with a focus on sources, transport, distribution, and conservation of biomarkers. The aim of this thesis was to apply water column biomarker data in the identification of microbial communities and microorganisms involved in methanotrophy, and their occurrences and distribution in the water column. Sediment samples were analyzed to assess the source and fate of biomarkers, particularly BHPs, in the sediment.

Initially, three common methods for the extraction of BHPs were tested. This study showed that the two phase solvent Bligh \& Dyer extraction enabled a higher recovery of BHPs with an amino group, such as aminotriol, aminotetrol, aminopentol, or BHT cyclitol ether. Besides, the LC-MS separation and the signal of BHT II were improved because of less non-LC amenable material in the extract. The single phase solvent ultrasound and microwave extraction gave very similar results for individual concentrations. All three methods had an almost equal recovery of total BHPs supporting their general applicability for BHP extraction.

In the second study, water column samples were taken from the Landsort Deep, the deepest part of the Baltic Sea. Samples collected in summer 2011 covered the whole water column and were analyzed for biomarkers representing different members of the microbial community. An oxic zone community of cyanobacteria, algae, dinoflagellates and ciliates was identified but was restricted to the surface layer. In contrast, the deeper but still oxic cold winter water layer showed only low abundances of biomarkers. The suboxic zone biomarkers reflected abundant and diverse prokaryotic and eukaryotic microorganisms and the related biogeochemical processes such as aerobic methanotrophy, heterotrophy, sulfate reduction and the oxidation of $\mathrm{H}_{2} \mathrm{~S}$. The anoxic zone was dominated by sulfate reducing bacteria that were assumed to be the in situ source of BHPs in this water depth and, most likely, methanogenic archaea. 
The third study described the first results of the "Aerobic and anaerobic methane consumption in the central Baltic Sea water column" project. A multidisciplinary methods approach in the Gotland Deep in summer 2008 combined biomarker analysis with gas chemistry and molecular biology. ${ }^{13} \mathrm{C}$ methane values substantiated the microbial origin of the methane in the anoxic water column. Enriched ${ }^{13} \mathrm{C}$ methane values and a strong decrease in methane concentrations indicated microbial consumption in the suboxic zone and first methane consumption rates could be calculated. DGGE analysis and the presence of indicative biomarkers with depleted $\delta^{13} \mathrm{C}$ values identified type I methanotrophic bacteria to be responsible for the effective aerobic oxidation of methane.

The following study also used the Gotland deep dataset collected in summer 2008. The analysis of Biomarkers was extended to cover the oxic and suboxic water column and surface sediments as well. Type I Methanotrophic bacteria were found to be concentrated in the central suboxic zone but biomarker concentrations suggested a relatively low total contribution to the microbial community. No evidence for type II methanotrophs was found. Depleted $\delta^{13} \mathrm{C}$ values of relevant lipids additionally proved the process of aerobic methanotrophy. A BHT isomer that was suggested to be a marker for oxic-anoxic interfaces in other stratified systems was identified in the Gotland Deep water column. Its occurrence exclusively in suboxic to anoxic samples supported its relation to stratified systems. The Gotland Deep surface sediments reflected the BHP composition of the suboxic zone, including the BHT isomer. Therefore, BHPs were assumed to be a possible tool for the reconstruction of past stratified environments.

Since the BHP signal of the surface sediments mirrored the modern stratified water column, research was expanded to include a Gotland Deep sediment core comprising all stages of the Holocene Baltic Sea development. The analysis of sedimentary $\mathrm{C}_{\text {org }}$ revealed low concentrations during the Baltic Ice Lake and Ancylus Lake stages, but a strong increase with the onset of the brackish-marine Littorina phase. The Medieval Climate Anomaly (MCA) and the Modern Warm Phase (MoWP) were marked by peaks in $\mathrm{C}_{\text {org }}$ concentrations. BHP concentrations reflected the $\mathrm{C}_{\text {org }}$ trend. During Baltic Ice Lake and Ancylus Lake stages, BHP concentrations were low, but increased with the Littorina Transgression and during MCA and MoWP. Furthermore, the BHT isomer indicative for water column stratification was absent 
in the early Baltic Sea stages and only occurred with onset of stratification. BHPs, thus, were successfully used to reconstruct the onset of the water column stratification in the Baltic Sea.

The studies presented in this thesis show that biomarkers are an important tool to gain information on the geobiology of the stratified water column of the central Baltic Sea. It was demonstrated that stratified water columns comprise various ecological niches for microorganisms that were able to adapt to these special conditions. The analysis of biomarkers in the Baltic Sea helped to identify different microbial communities, the related biogeochemical processes, and the vertical restriction of these ecological niches in the present and also the past environments. However, the situation of the central Baltic Sea with lateral intrusions and larger inflows potentially oxidizing the whole water column has been highly dynamic since the onset of the stratification. Microorganisms were forced to not only adapt to the stable stratification but also to its disturbances. Consequently, future geobiological studies of these continuously changing interactions of geosphere and biosphere will be of great interest. 


\section{Curriculum Vitae}

\section{Personal Information}

Name:

Date and Place of Birth:
Christine Berndmeyer

$18^{\text {th }}$ September 1984, Cloppenburg, Germany

\section{University}

2011 - present

$2007-2011$

$2008-2009$

$2004-2007$

\section{School}

1997 - 2004

1995 - 1997

1990 - 1995
Graduate student (PhD), Georg-August-University Göttingen, Germany

Topic: "Aerobic and anaerobic methane consumption in the water column of the central Baltic Sea". Supervisors: Prof. Dr. Volker Thiel, Dr. Martin Blumenberg

Graduate student (MSc), Marine Geosciences, University of Bremen, Germany

Master's thesis: "Aspects of bacterial activity on the formation of phosphorites in the Miocene Monterey Formation, California". Supervisors:

Prof. Dr. Jörn Peckmann, Dr. Timothy Ferdelman

Graduate student scholarship (10 months), Ocean University of Qingdao, China

Intensified studies of marine geology, marine biology and oceanography

Undergraduate student (BSc), University of Bremen, Germany

Bachelor's thesis: "Terrigenious sediment input into the Eastern Tasman Sea, 0-120ky" (written in German).

Supervisors: Prof. Dr. Ralf Tiedemann, Dr. Jürgen Pätzold

Gymnasium "Unserer Lieben Frau", Cloppenburg

Abitur (University entrance qualification)

Orientierungsstufe "Don Bosco", Cloppenburg

Grundschule "Wallschule", Cloppenburg 